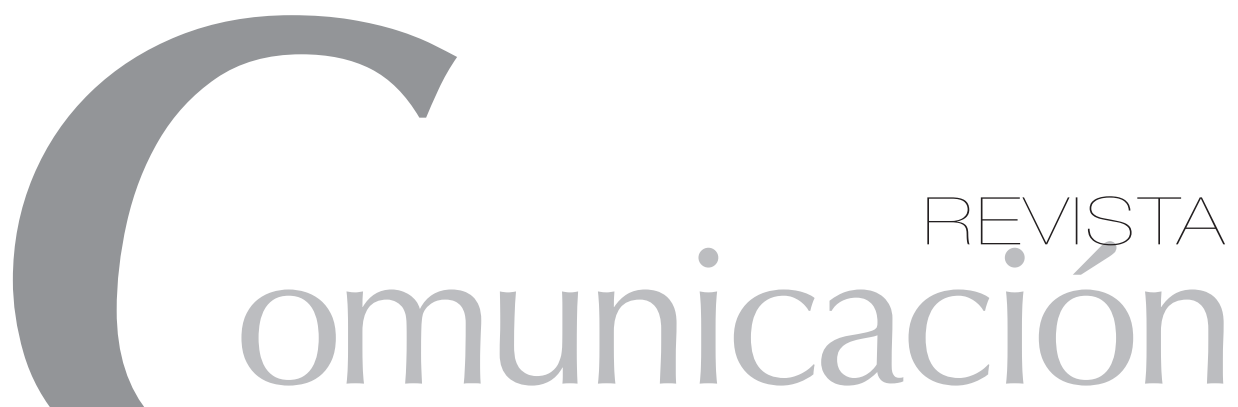

Revista Comunicación. Volumen 27, año 39, núm. 1, enero-junio, 2018. ISSN 0379-3974

\section{CONTENIDO}

\section{ARTÍCULOS}

El descensus ad inferos en la Eneida: muerte simbólica de Eneas y legitimación de Augusto

Minor Herrera.

La écfrasis metaléptica: recurso representacional en Una novelista en el Museo del Louvre, de Zoé Valdés

Iraida L. Bárzaga Morales 19

Los cuerpos cíborgs en cuatro cuentos de ciencia ficción costarricense

Diana Martínez Alpízar .35

"Te extraño, te olvido, te amo de nuevo". La construcción del amor en la literatura juvenil argentina

Giuliana Pates.

Totalitarismo y democracia individualizada: Un análisis de La Ola de D. Gansel

Aleixandre B. Duche-Pérez, Rogelio Scott-Insúa, José Carlos Salinas-Valdivia y Mag. David Blaz Sialer

La búsqueda de la felicidad doméstica en La città e la casa de Natalia Ginzburg

María Belén Castano

Gráfica de Atención Completa (G.A.C.), una propuesta metodológica educativa, mediante proyectos interdisciplinares para el aprendizaje y mejora de la capacidad de atención - concentración a través del audiovisual y el arte

Francisco Cuéllar Santiago e Isidro López-Aparicio Pérez . .84

La pronunciación en inglés para estudiantes de primer año de primaria: una secuencia didáctica para su mejoramiento

Karin Sepúlveda N ., Cecilia Quiroga C. y Claudio Díaz L. 108

\section{ENSAYOS}

La enseñanza del arte en la escena global. El proyecto colaborativo entre el Centro de Investigaciones Artísticas (CIA) y la Maestría en Estéticas Contemporáneas Latinoamericanas (MECL/UNDAV)

Gabriela A. Piñero

La piedra literaria en el zapato de Bob Dylan: un análisis a la crítica temprana a su Nobel en Costa Rica y a su valor poético-literario

David Boza Méndez. 132

\section{TABLE OF CONTENTS}

\section{PAPERS}

The descensus ad inferos in the Aeneid: symbolic death of Aeneas and legitimation of Augustus

Minor Herrera.

The ekphrasis metaleptica: representational resource in Una novelista en el Museo del Louvre, of Zoé Valdés

Iraida L. Bárzaga Morales

The cyborg bodies in four Costa Rican

science fiction short histories

Diana Martínez Alpízar.

"I miss you, I forget you, I love you again." The construction of love in Argentinian young adult literature

Giuliana Pates

Totalitarianism and individualized democracy: An analysis of Die Welle by D. Gansel

Aleixandre B. Duche-Pérez, Rogelio Scott-Insúa,

José Carlos Salinas-Valdivia y Mag. David Blaz Sialer

The search for domestic happiness in

Natalia Ginzburg's La città e la casa

María Belén Castano

Complete Attention Graphic (G.A.C.), an Educational Methodological Proposal through Interdisciplinary Projects for Learning and Improving AttentionConcentration Capacity through Audiovisual and Art Francisco Cuéllar Santiago e Isidro López-Aparicio Pérez . .84

English pronunciation for first year primary school students: a didactic sequence implementation for its improvement

Karin Sepúlveda N ., Cecilia Quiroga C. y Claudio Díaz L. 108

\section{ESSAYS}

Art Education in the Global Scene. The Collaborative Project between the Center for Artistic Research $(\mathrm{CIA})$ and the Master Program in Contemporary Latin American Aesthetics (MECL/UNDAV)

Gabriela A. Piñero

The literary pebble in Bob Dylan's shoe: an analysis of the early criticism in Costa Rica on his Nobel and his poetic-literary value David Boza Méndez 132 


\section{OMunicación}

PUBLICACIÓN DEL INSTITUTO TECNOLÓGICO DE COSTA RICA • ESCUELA DE CIENCIAS DEL LENGUAJE VOL. 27, AÑO 39, núm. 1, enero-junio, 2018 • ISSN 0379-3974

Comunicación es una revista del Instituto Tecnológico de Costa Rica, editada por la Escuela de Ciencias del Lenguaje. Ofrece a sus lectores dos números regulares al año y, ocasionalmente, ediciones especiales.

Su objetivo es publicar el resultado de las investigaciones que diversos académicos efectúan en Hispanoamérica, Europa y Estados Unidos, en los campos de las Humanidades y Educación. También difunde la creación literaria original de escritores destacados.

La Revista Comunicación mantiene su adhesión al código de ética COPE.

The objective of this journal is to spread the scientific production in the fields of literature, linguistics, humanities, arts, literary theory, philosophy and music. This takes place through the biannual publication of original and unpublished articles. Moreover, these articles disclose results related to investigations, theoretical and methodological contributions, literary productions as well as bibliographic reviews. The journal has an International Scientific Committee and also national and international blinded peer reviewers.

The authors cannot make changes to the final tests.

\section{ÍNDICES DIGITALES}

Comunicación está inscrita en:

- SciELO: http://www.scielo.org

- LATINDEX http://www.latindex.unam.mx/

(Sistema Regional de Información en Líneas para Revistas

Científicas de América Latina, el Caribe, España y Portugal).

- LANIC www.lanic.utexas.edu/indexesp.html

(Latin American Network Information Center).

- DOAJ www.doaj.org/ (Directory of Open Access Journals).

- Portal de Revistas del Instituto Cervantes (portal del Hispanismo): www.hispanismo.cervantes.es/revista.asp

- e-revistas: http://www.erevistas.csie.es

- Erih plus: http://dbh.nsd.uib.no

- Sicultura (Sistema de Información Cultural Costa Rica): http://www.si.cultura.cr

DIRECTORA

MSc. Elizabeth Corrales Navarro, Instituto Tecnológico de Costa Rica E-mail: ecorrales@itcr.ac.cr

\section{CONSEJO CIENTÍFICO}

Dr. Arnoldo Mora, Universidad Nacional, Costa Rica Dra. Valeria Grimberg Pla, Universidad de Frankfurt, Alemania Dr. Francisco Rodríguez, Sede de Occidente, Universidad de Costa Rica Lic. Guillermo Coronado, Universidad de Costa Rica $\mathrm{PhD}$. Zaline M. Roy-Campbell,Syracuse University Dra. Jessica Páez Arias, Univ. De Antioquia, Colombia Dr. Jorge Machín-Lucas, Universidad de Winnipeg, Canadá

\section{CONSEJO EDITORIAL}

Dr. Edwin Marín Arroyo, Instituto Tecnológico de Costa Rica Dra. Verónica Ríos Quesada, Instituto Tecnológico de Costa Rica Mag. Nuria Vindas Fernández, Instituto Tecnológico de Costa Rica ML. Dimitri Shiltagh Prada, Instituto Tecnológico de Costa Rica

\section{RECONOCIMIENTO}

Se agradece la colaboración de la Vicerrectoría de Docencia del ITCR.

Traductor: Mag. Mónica Gómez Hendriks Correctora filológica: Br. Shirley Barquero V.

\section{CORRESPONDENCIA:}

\section{Dirección Postal:}

Escuela de Ciencias del Lenguaje / Instituto Tecnológico de Costa Rica / Revista Comunicación

Apdo. 159-7050 Cartago, Costa Rica / Fax: 2550-9144

Dirección electrónica: recom@itcr.ac.cr

Sitio web: http://www.tec-digital.itcr.ac.cr/servicios/ojs/index.php/ comunicacion

Teléfonos: (506) 2550-9102 (506) 2550-9024

La responsabilidad por el contenido es exclusivamente de los autores. Deben respetarse los derechos de autor y de divulgación.

DISEÑO GRÁFICO E IMPRESIÓN

Publicaciones TEC.

\section{¿Desea ser patrocinador de la Revista Comunicación del ITCR?}

Deseo colaborar con la suma de:

\begin{tabular}{|c|c|c|}
\hline$\$ 5000$ al mes & $\square$ & $\$ 10000$ al trimestr \\
\hline$\$ 15000$ al semestre & $\square$ & $\$ 28000$ al año \\
\hline
\end{tabular}

Únicamente requiere depositar su dinero en una de las cuentas de la Fundación del Tecnológico, e indicar que el monto se debe destinar para el código de la Revista Comunicación núm. 5-272.

\begin{tabular}{|l|l|l|}
\hline \multicolumn{1}{|c|}{ Banco } & $\begin{array}{c}\text { Cuenta para depósitos } \\
\text { bancarios }\end{array}$ & $\begin{array}{c}\text { Cuenta para transferencias } \\
\text { electrónicas }\end{array}$ \\
\hline Banco Nacional de Costa Rica & $100-01-075-003959-4$ & $151-075-10010039596$ \\
\hline Banco de Costa Rica & $275-0004039-8$ & $152-01275000403987$ \\
\hline
\end{tabular}

Con su patrocinio, puede ayudar a que nuestra publicación sea cada vez mejor.

¡Muchas gracias por cooperar con nosotros! 


\section{Presentación}

Hacer investigación no es cosa fácil. Mucho menos, en una región, como la nuestra -latinoamericana- que carece de recursos económicos abundantes como para destinarlos a la investigación en Humanidades. Por eso, este nuevo número nos llena de orgullo, pues contiene el resultado de diversas investigaciones en América Latina, específicamente en esta área del saber.

Tiene usted, estimado lector, en sus manos, una exclusiva selección de trabajos de investigación en literatura, que incluyen, desde el análisis de un poema tan clásico como la Eneida, elaborado hábilmente por el máster Minor Herrera, hasta el novedoso estudio de cuentos de ciencia ficción costarricense, realizado magistralmente por la ML. Diana Martínez, pasando por la acuciosa exploración sobre la obra de Valdés, hecha por la Dra. Iraida Bárzega, la exploración profunda que hace la máster María Belén Castano sobre la crisis de la familia tradicional pequeñoburguesa en la obra La città e la casa, de Ginzburg, el razonamiento planteado por el máster David Boza sobre la crítica al Nobel otorgado a Bob Dylan, y el examen al que somete la máster Giuliana Pates a la construcción del amor en la literatura juvenil argentina.

Con el fin de colaborar en la mejora de la enseñanza de las distintas áreas del saber y con diversos grupos, también le ofrecemos las propuestas metodológicas y experiencias pedagógicas que hacen los Dres. Isidro López y Claudio Díaz, el licenciado Francisco Cuéllar y las magístras Karin Sepúlveda y Cecilia Quiroga.

De igual modo, encuentra usted en este número una profunda y novedosa explicación de la película "La Ola", hecha por los expertos Aleixandre Duche, Rogelio Scott-Insúa, José Carlos Salinas y David Blaz.

Como notará, apreciado lector, tiene en sus manos una joya de la Academia. ¡Disfrútela!

MSc. Elizabeth Corrales N.

Directora 


\title{
El descensus ad inferos en La Eneida: muerte simbólica de Eneas y legitimación de Augusto
}

\author{
Por Minor Herrera Valenciano', Universidad de Costa Rica \\ Recibido: 29 de mayo, 2017. \\ Aceptado: 12 de marzo, 2018.
}

\section{Resumen}

Este trabajo analiza el descensus ad inferos realizado por Eneas, en el libro VI de la Eneida, a partir de dos perspectivas: por un lado, como la confrontación del héroe con su propia condición mortal, que es superada gracias a la promesa de una gens majestuosa como los dioses, por medio de la cual perpetuará su linaje, mientras que -por otra parte- se analiza en ese mismo descensus ad inferos la legitimación del poder político de Augusto como una legitimación que llega hasta la consagración del Princeps, pues las promesas de una apoteosis del héroe Eneas y sus descendientes están concatenadas en la trama de la Eneida y confieren al linaje de los gobernantes al que pertenece el emperador Augusto una legitimidad divina y ancestral, como ocurre con sus ancestros divinos, Eneas y Rómulo, con lo cual se ganará un espacio entre las deidades olímpicas y pone fin a la batalla encarnizada en contra de la muerte y la posibilidad de ser olvidado. De ahí que la muerte simbólica de Eneas al ingresar al inframundo y surgir de él sea medular tanto en el devenir de las acciones del texto como para las aspiraciones apoteósicas del emperador en la realidad.

\section{Abstract \\ The descensus ad inferos in the Aeneid: symbolic death of Aeneas and legitimation of Augustus}

This work analyzes Aeneas's descendus ad inferos in book VI of the Aeneid, from two perspectives: On the one hand, it deals with the hero's confrontation with his mortal condition-overcome thanks to the promise of a majestic godlike gens, that will perpetuate his lineage. On the other hand, it analyzes Augustus's legitimation of political power in the same descensus ad inferos, extending to the consecration of the Princeps, since the promise of an apotheosis for the hero Aeneas and his descendants is implicit in the plot of the Aeneid and confers the lineage of the rulers to whom the Emperor Augustus belongs a divine and ancestral legitimacy. This is the case of his divine ancestors, Aeneas and Romulus, who are awarded a space within the Olympic deities, thus putting an end to the bitter battle against death and possibility oblivion. As such, Aeneas's symbolic death when entering the underworld and emerging from it is as central to the development of the action as it is for the Emperor's true apotheotic aspirations.

1 Máster en Literatura Clásica graduado de la Universidad de Costa Rica. Labora en la Escuela de Filología, Lingüística y Literatura de la Universidad de Costa Rica. Contacto: minorj2007@hotmail.com.

PALABRAS CLAVE:

Literatura, historia, religión antigua, mitología, muerte, rito.

\section{KEY WORDS:}

Literature, history, ancient religion, mythology, death, rite. 


\section{INTRODUCCIÓN}

En el recorrido que realiza por la Mansión de Dite, Eneas avanza entre diversas regiones, cada una organizada a partir de consideraciones morales y éticas relacionadas con lo deseable y lo repudiable para los romanos (al ser el poema un instrumento propagandístico de las mores maiorum), siendo así que se presentan de manera en forma escalonada que va desde los lugares más abominables hasta los más hermosos, como es el caso de los Campos Elíseos.

Según Toynbee (1996) y Blázquez, Martínez-Pinna y Montero (1993), en Roma hubo dos consideraciones sobre la vida en el más allá. La primera sería la creencia arcaica que imaginaba que el alma permanecía ligada a la tumba. Vayne, citado por Abascal (1991) afirmaba que "la tumba es la morada eterna en que todo se prolonga una vez que ha cesado y donde la nada adopta las apariencias consoladoras de una monótona identidad" (p. 208). La segunda era la creencia republicana, la cual manifestaba que después de la muerte se daba inicio a una nueva vida en el más allá. Al parecer, este cambio de paradigma en torno de la muerte surge gracias a las influencias griegas y etruscas, pues ambas poseían la creencia de un mundo ultraterreno donde iban a parar todas las almas.

Según lo mostrado en La Eneida, el inframundo estaba dividido en al menos cinco diferentes tipos de residencias; la primera era donde se encontraban los insepultos, ya que las almas debían esperar cien años antes de ser trasladadas por Caronte; la segunda donde se encontraban aquellas almas que habían llegado prematuramente, como es el caso de los niños; la tercera era el Tártaro, donde algunas almas iban a sufrir; la cuarta era los Campos Elíseos, donde las almas buenas iban a refocilarse y la quinta era una zona neutra donde los suicidas debían esperar por largo tiempo hasta que Caronte considerara oportuno trasladarlos en su barca.

En cada uno de dichos espacios se ofrece información valiosa al héroe, a partir de la que toma decisiones que lo ayudarán a conseguir sus objetivos. Además, la información aportada por Virgilio será comprendida como punto de partida para la consagración de la figura del Princeps.
A partir de lo anterior, la importancia de este trabajo radica en analizar el descensus ad inferos realizado por Eneas a partir de dos perspectivas; por un lado, como la confrontación del héroe con su propia condición mortal, que es superada gracias a la promesa de una gens excelsa como los dioses, por medio de la cual perpetuará su linaje, mientras que -por otra parte- en ese mismo descensus ad inferos queda manifiesta la legitimación del poder político de Augusto; pero es una legitimación que va más allá, pues las promesas de una apoteosis del héroe Eneas y sus descendientes están concatenadas en la trama de la Eneida y confieren al linaje de los gobernantes al que pertenece el emperador Augusto una legitimidad divina y ancestral, como ocurre con sus ancestros divinos, Eneas y Rómulo, con lo cual se ganará un espacio entre las deidades olímpicas y pone fin a la batalla encarnizada en contra de la muerte y la posibilidad de ser olvidado. De ahí que la muerte simbólica que posee Eneas al ingresar al inframundo y surgir de él sea medular tanto en el devenir de las acciones del texto como para las aspiraciones apoteósicas del emperador en la realidad.

\section{DESCENSUS AD INFEROS: LA MUERTE SIMBÓLICA DE ENEAS}

Para comprender el descensus ad inferos, como el realizado por Eneas, solamente puede lograrse rela-

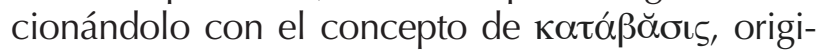
nado en la Grecia Antigua y considerado como un acontecimiento obligatorio dentro de la tradición épica. Fue mostrado por Homero en el texto de la Odisea cuando su protagonista hace una véкvı $\alpha$ para encontrarse con Tiresias y de esa manera obtener información que lo ayudase a retornar a Ítaca. En oposición a Odiseo, luego de su encuentro con Anquises, Eneas toma consciencia de que no hay vuelta atrás y que su hado (y el de su pueblo) lo impulsan, a la vez que lo obligan a emprender el viaje hacia una nueva tierra, aunque todo esto implique deponer sus deseos ante los de su raza, lo cual pone de manifiesto - una vez más- lo bien atribuido que tiene el epíteto de pius.

Unido a lo anterior, es preciso comprender el sentido de la palabra catábasis y para eso hay que recurrir a la etimología de esta. Según el diccionario 
Liddell-Scott-Jones (1992, P. 302), en adelante, LSJ (1992, p. 302), el verbo griego ßaív $\omega$ posee los siguientes significados: (1) caminar, marchar, andar, dar un paso; (2) estar de pie, estar en un lugar; (3) irse, salir de algún lugar; (4) venir; (5) seguir, avanzar y (6) montar. Todas las acepciones de la palabra son utilizadas para indicar la acción de moverse o desplazarse. Sin embargo, no indica la dirección del movimiento; de ahí que el griego recurra a los

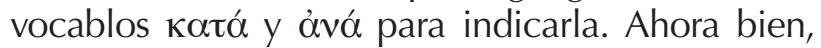
de acuerdo con LSJ (1992, pp. 882-884), la palabra xató indicaría la acción de realizar un movimiento hacia abajo o descendente, mientras que ỏvó tendría el sentido de llevar a cabo un movimiento que se realiza hacia arriba (pp. 97-98).

Atendiendo a la etimología de dichas palabras y lo mencionado por Morales (2012), la óvóßaбıs será aquel desplazamiento que se hace de abajo hacia arriba, lo cual tendrá el mismo significado de la expresión latina ascensus ab inferos (ascenso desde el

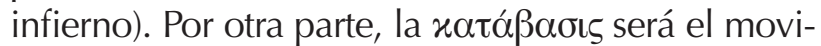
miento realizado desde arriba hacia abajo, al igual que la frase latina descensus ad inferos (descenso hacia el infierno). Tales palabras designan una perspectiva binaria del mundo, el cual se dividiría en el hemisferio de los vivos, que sería el que se encuentra arriba y el hemisferio de los muertos, el más allá, que se encuentra en las entrañas de la tierra.

En esa misma línea de análisis, González (1999, p. 130) menciona que "la idea de la «catábasis»; es decir, el descenso al infierno y la posterior salida de él (anábasis o resurrección) aparece inmersa desde la más remota antigüedad, en el marco de las creencias funerarias de casi todas las civilizaciones del mundo". Así pues, el culto funerario a los muertos ha sido un hecho desde el Neolítico (o desde las fases finales del Paleolítico), tanto por necesidades higiénicas como de piedad hacia los difuntos.

Otra de las creencias funerarias que se arraigó durante muchísimo tiempo en la Grecia Antigua y en otras civilizaciones fue la de descender al infierno cuando se requería información sobre el pasado, el presente o el futuro propio o de los pueblos, debido a que con el descenso se buscaba tener algún tipo de relación con los hombres sabios que moraban en el inframundo.
En relación con eso, Eliade (1960, p. 301) menciona que "los muertos conocen el futuro, pueden revelar las cosas ocultas...". De esta manera, cuando el héroe virgiliano emprende su aventura por el inframundo, además de enfrentarse a duras pruebas, es consciente de que podrá obtener información valiosa a la que, de otra manera, jamás podría acceder.

Estos sabios del inframundo instruyen al héroe y permiten que alcance la sabiduría necesaria para responder a los cuestionamientos que no le permiten tener claridad a la hora de tomar decisiones respecto de sí mismo o su gente. Así, los dioses, semidioses y héroes más importantes de las mitologías (Marduk, Gilgamesh, Heracles, Orfeo, Teseo, Odiseo, Eneas, Jesús, etc.) descendieron a los infiernos, donde todos tuvieron inolvidables experiencias y en muchos casos, obtuvieron información valiosa que les ayudó a alcanzar sus objetivos.

Por otra parte, lo importante era poder imaginar una escapada del mundo de las tinieblas, una anábasis que permitiese al héroe renacer con nuevos conocimientos y la claridad mental necesaria para alcanzar sus objetivos, una salida del inframundo donde los muertos -en el mejor de los casos- solo son sombras o dobles al igual que sucedía en el Hades de los griegos. Con respecto a los dobles, Rhode (2009, p. 85) afirma que desde tiempos prehoméricos existía la creencia de que dentro del hombre se albergaba un ser vivo, plenamente animado, un ente "extraño", una especie de doble mucho más frágil que el hombre vivo, su otro yo. Asimismo, desde el punto de vista del recorrido mítico heroico, el descenso que el personaje realiza al inframundo se da con la intención de buscar respuesta o consejo ante los problemas que sobrelleva fuera del mundo ctónico.

Es necesario afirmar que los conceptos de catábasis y anábasis forman parte de una extensa tradición épica, que ha sido reescrita una y otra vez a lo largo de la historia, y que Mircea Eliade considera una estructura mítica del pensamiento humano.

La realización de una catábasis es un hecho común en el proceso de formación del héroe épico, ya que este ingresa a las profundidades de la tierra pensando de una manera y surge de ella siendo alguien completamente distinto. Es ahora más fuerte, confía en sí mismo y en su futuro. Así pues, la muerte simbólica del héroe representa el término de la 
condición profana y la adquisición de la sabiduría y en ese sentido, la muerte se convierte en "la expresión paradigmática del 'final de un modo de ser': el modo de la ignorancia y la irresponsabilidad" (Eliade, 2001, p. 14). Vale destacar que para Eliade (1960) los seres humanos comparten su destino con el de las plantas y por ello mismo, se integra en el ciclo infinito de nacimiento, de muertes y renacimientos (p. 59).

Este descenso al interior del mundo, a las entrañas de la tierra o de la Tellus Mater, representa la muerte simbólica del héroe, quien al retornar del inframundo se muestra insuperable, capaz de triunfar ante cualquier prueba y contra cualquier individuo que se atraviese en su camino. Se trata de una muerte simbólica, porque la realidad es que el héroe no muere físicamente, sino que lo hace de manera figurativa, debido a que el descenso realizado hacia el inframundo representa el pasaje de las almas en su peregrinar hacia las profundidades del Averno. Sin embargo, el personaje heroico no pretende permanecer eternamente en ese lugar, como lo hacen las almas de los muertos, pues para eso realiza la anábasis, mediante la cual adquirirá la condición de dominador de los dos mundos, el de los vivos y el de los muertos. Es decir, de manera simbólica y gracias a la anábasis realizada ha resucitado o -en otras palabras- ha vencido a la muerte. Eliade (2001) piensa que en la mayoría de los ritos de pasaje o de iniciación la conclusión de estos radica en el ascenso, mediante el cual el héroe se proyecta hacia lo alto, hacia lo etéreo, constituyéndose como un axis mundi, que enlaza los tres espacios en los que se divide el cosmos: infierno, tierra y cielo, con lo que al final logrará resurgir bajo la condición de "consagrado". Ahora se asemeja a los dioses, ahora es "un hombre que puede comunicarse personalmente con dioses, demonios y espíritus" (Eliade, 2001, p. 134).

Unido a lo anterior, la catábasis que realiza Eneas en el libro $\mathrm{VI}$ se posiciona en el poema virgiliano como uno de los pasajes de mayor riqueza simbólica, pues dicho recorrido define la culminación del recuerdo o añoranza de Troya y marca el inicio de la visualización futura de Roma. Simbólicamente, se podría reconocer en el tránsito por el más allá la necesidad de superar la condición mortal de los seres humanos; es decir, se trata de ir más allá de la finitud, de transgredir los límites de la naturaleza humana y conquistar la muerte para alcanzar la inmortalidad. Por su parte, Albiac (1996) aproxima el concepto de katábasis al desenlace de algunas peripecias ocurridas al héroe durante su periplo. Menciona que la antesala del viaje hacia el infierno es el naufragio, cuando las naves en las que va el héroe son derrotadas y él da en una playa ignota, ya que -posterior a eso- las preguntas que le surgen lo llevan a cuestionarse por todo y la búsqueda de las respuestas constituirá la motivación requerida para realizar el descenso.

El descenso al Averno es para Eneas el regreso al útero de la Gran Madre Tierra, es ingresar a las entrañas del mundo y representa simbólicamente que el héroe ha muerto, para renacer como un ser nuevo. Así pues, el descenso significa la autoaniquilación del héroe para su posterior renacimiento, como lo propone Campbell (2008): "el héroe va hacia adentro, para renacer. Su desaparición corresponde al paso de un creyente dentro del templo, donde será vivificado por el recuerdo de quién y qué es, o sea polvo y cenizas a menos que alcance la inmortalidad" (p. 89).

Eliade (2007) concuerda con Campbell cuando se refiere al descenso al inframundo como un rito de pasaje e iniciación heroica. Al respecto afirma que "el regreso a la madre significa regresar a la gran Madre Telúrica. El iniciado vuelve a nacer en el útero de la Madre Tierra" (p. 95) y reaparece más poderoso que antes. En su mayoría, los ritos de iniciación requieren una muerte simbólica, la cual constituye un instante fundamental, seguida de un renacimiento, igualmente simbólico y finaliza con el retorno hacia su pueblo o su gente. Eliade (2001) al respecto afirma que:

La experiencia de muerte y resurrección iniciáticas no solo cambia básicamente el modo de ser fundamental del neófito, sino que al mismo tiempo le revela la sacralidad de la vida humana y del mundo, revelándole el gran misterio, común a todas las religiones, de que los hombres, junto con el cosmos y todas las formas de vida, son la creación de los dioses o de los seres sobrenaturales (p. 43). 
Así las cosas, en el proceso de configuración heroica, la muerte simbólica reflejada con la catábasis realizada por el héroe fortalecerá el proceso de configuración o transformación del personaje común en personaje heroico. Además, dicho ingreso al inframundo simboliza la purificación heroica, su punto máximo y el alcance de su madurez plena, pues es dominador de los dos mundos (el de la superficie y el subterráneo).

Pero Eneas no realiza el viaje hacia los rincones del inframundo, porque haya nacido en él el deseo, sino porque su padre Anquises lo exhorta durante un sueño. Al respecto, según lo mencionado por Rhode (2009, p. 52), para los antiguos el hombre que soñaba y lo que veía en sueños hacía que creyeran y confirmaran la existencia de un segundo "yo" con vida propia: "Esto quiere decir que vive en él, alojado en su interior, otro yo, el que obra en sueños, mientras aquel duerme" (p. 12). El pasaje completo es el siguiente:

\begin{tabular}{|c|c|}
\hline $\begin{array}{l}\text { Y la negra Noche } \\
\text { Ilevada por su biga } \\
\text { ocupaba el cielo. } \\
\text { Caída entonces del } \\
\text { cielo se le apareció la } \\
\text { imagen de su padre } \\
\text { Anquises de pronto } \\
\text { que le infundía } \\
\text { estas palabras: } \\
\text { «Hijo a quien quise } \\
\text { un día más que a mi } \\
\text { vida, cuando la vida } \\
\text { tenía, hijo a quien } \\
\text { han probado de } \\
\text { Ilión los hados, } \\
\text { aquí llego por orden de } \\
\text { Jove, que apartó el fuego } \\
\text { de tus naves y se } \\
\text { compadeció al fin } \\
\text { desde el alto cielo. } \\
\text { Atiende los consejos } \\
\text { que ahora te brinda } \\
\text { bellísimos } \\
\text { el anciano Nautes; }\end{array}$ & $\begin{array}{l}\text { Et Nox atra polum bi- } \\
\text { gis subuecta tenebat: } \\
\text { uisa dehinc caelo fa- } \\
\text { cies delapsa parentis } \\
\text { Anchisae súbito tales } \\
\text { effundere ouces: } \\
\text { "Nate, mihi uita quon- } \\
\text { dam, dum uita mane- } \\
\text { bat, } \\
\text { care magis, nate Iliacis } \\
\text { exercite fatis, } \\
\text { imperio louis huc, ue- } \\
\text { nio, qui classibus ig- } \\
\text { nem } \\
\text { depulit, et caelo tán- } \\
\text { dem miseratus ab alto } \\
\text { est. } \\
\text { Consiliis pare quae } \\
\text { nunc pulcherrima } \\
\text { Nautes }\end{array}$ \\
\hline
\end{tabular}

Ilévate a Italia jóvenes escogidos, los más esforzados corazones. Tendrás que pelear en el Lacio con un pueblo duro y salvaje. Antes, sin embargo, entra en las mansiones infernales de Dite y por el profundo Averno ven, hijo, a mi encuentro. Que no me tiene el impío Tártaro, las tristes sombras, sino que frecuento los amenos concilios de los píos y el Elisio. Aquí la casta Sibila te guiará con mucha sangre de negros animales. Entonces toda tu raza conocerás y qué murallas te aguardan. Y ahora, adiós; dobla la mitad de su carrera la húmeda Noche y cruel Oriente me ha soplado el aliento de sus caballos». Había dicho y escapó a las auras tenue como humo.

El espectro de Anquises se manifiesta para aclarar los pensamientos de Eneas, pero su función es más que esa. Lo que pretende es encaminar a su hijo hacia los campos Elíseos para mostrarle el destino de su raza. Es un acontecimiento motivador, pues hace ver a Eneas que su viaje tiene un verdadero sentido y realmente existe una tierra que aguarda por él y su gente.

Al respecto, Campbell (2008) afirma que es en esta prueba, en el reencuentro con el padre, en la que "se abre la posibilidad de que el héroe derive 
esperanza y seguridad" (p. 123), ante el acontecer aciago de los hechos que le ha correspondido vivir; es decir, que la aparición de Anquises le transmite el empuje necesario para continuar su viaje hasta el final.

Por otra parte, la catábasis realizada por Eneas es muy representativa, ya que tiene dos metas: por un lado saber lo que le espera a sus compañeros, a sí mismo y su estirpe, y por otro, reencontrarse con su padre Anquises, lo cual corresponde a uno de los estadios que según Campbell (2008) el héroe debe completar para lograr su formación y completud:

... para el hijo que ha llegado a conocer al padre verdaderamente, las agonías de la prueba pasa con rapidez; el mundo ya no es un valle de lágrimas, sino la perpetua y bendita manifestación de la presencia ( $p$. 139).

Eneas y su padre Anquises tienen mucho tiempo de no verse (desde la muerte del padre, cerca de las costas de Sicilia). En ese reencuentro, el padre le brinda una prospección acerca del futuro de los Dárdanos. El hecho de reencontrarse con Anquises hace que tenga nuevas fuerzas y olvide los trabajos que lo han doblegado; además, conocer su futuro y verlo alentador motiva al héroe, quien luego debe realizar la anábasis -la resurrección simbólica-para volver con sus compañeros.

La siguiente cita es reflejo de lo anterior:

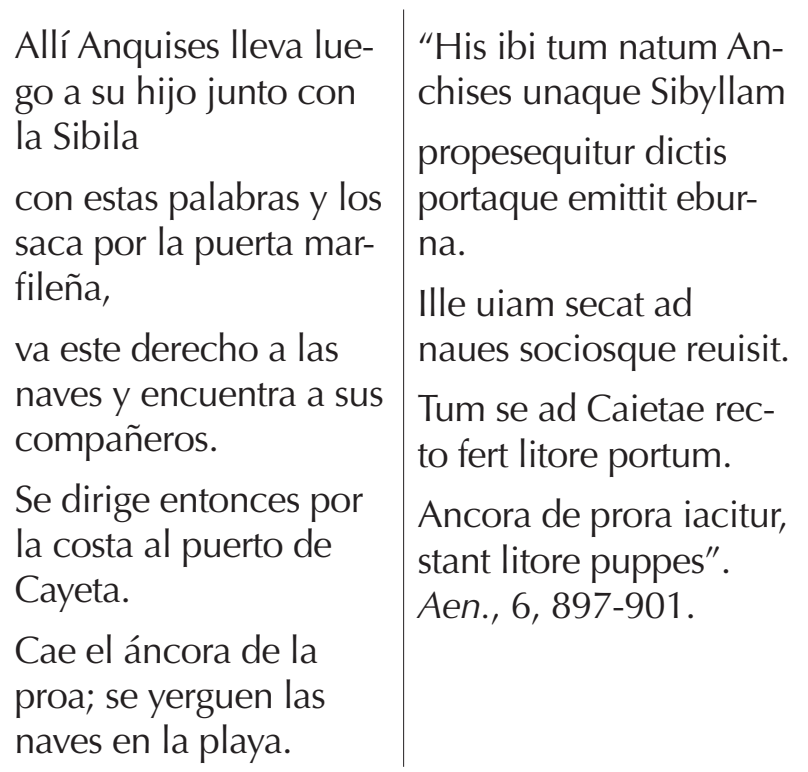

El héroe Eneas está en la obligación de ascender desde el Averno y cruzar el umbral. Es el segundo, solo que esta vez es el que lleva a la salida. Es la puerta que conduce de regreso al mundo de los vivos. De esa manera, como se mencionó, se trata de una resurrección heroica, un renacer en fuerza y destreza que lo prepara para las pruebas que le obstaculizarán su Ktísis (recorrido fundador de una ciudad).

Una vez que el héroe abandona sin daño alguno los aciagos caminos de la muerte, se muestra glorioso y con esto, fortalece su imagen y acrecienta su buena fama, lo cual hará que sus hazañas y su nombre sean recordados eternamente. Tal como lo considera Felton (2007):

... the hero having to face his own mortal nature, overcome his fear of death, and realice that the best way for a mortal to attain inmortality is to achieve a heroic reputation through brave and memorable deeds (p. 94) $)^{2}$.

No solo Eneas es presentado en el poema épico virgiliano como realizador de un descenso al Averno. Antes que él son mencionados, por un lado, Heracles y por otro, Teseo y Pirito; el primero en cumplimiento de uno de los trabajos encomendados por Euristeo y los segundos, producto de sus andanzas amorosas en el temerario afán de librar o secuestrar a Proserpina. Así dice el pasaje:

\footnotetext{
2 Traducción propia: ... el héroe tiene que enfrentarse a su propia naturaleza mortal, superar su miedo a la muerte y darse cuenta de que la mejor manera para que un mortal alcance la inmortalidad es lograr una reputación heroica a través de valientes y memorables hazañas.
} 
Éste es el lugar de las Vmbrarum hic locus sombras, del sueño y la est, somni noctisque sonoche soporosa: porae;

cuerpos vivos no puede corpora uiua nefas Styllevar la barca estigia. gia uectare carina.

Tampoco me alegré de Ne cuero Alciden me recibir a Alcides en mi sum laetatus euntem lago

cuando bajó, ni a Teseo y Pirítoo,

aunque hijos eran de dioses y de fuerza invencible.

Aquél vino a encadenar con su mano al guardián del Tártaro

y lo arrancó tembloroso del trono del mismo rey; accepisse lacu, nec Thesea Pirithounmque, dis quamquam geniti atque inuicti uiribus essent.

Tartareum ille manu costodem in uincla petiuit

ipsius a solio regis traxitque trementem;

hi dominam Ditis thalamo deducere adorti. éstos llegaron para sa- Aen., 6, 391-397. car a mi señora del tálamo de Dite.

Al respecto, cabe destacar que según Pirre Grimal (2008): "El undécimo trabajo impuesto a Heracles por Euristeo consistió en enviarle a los infiernos con la orden de que le trajese de allí el perro Cerbero. Heracles, pese a su valor, no habría podido salir bien de esta empresa, si, por mandato de Zeus, no le hubiesen ayudado Hermes y Atenea" (p. 247).

En el caso de esos héroes, el objetivo por el que realizan el viaje al mundo de las sombras no tiene relación con el develamiento de informaciones valiosas, como sí ocurre en el caso de Odiseo y posteriormente de Eneas.

Por otra parte, Felton (2007, pp. 97-98) dice que antiguamente a los muertos se les dotaba de cierto carácter profético, es decir, que guardaban consigo mensajes y conocían sucesos ocultos para quienes se encontraban con vida. Esto conlleva a pensar que el descenso realizado al Averno tiene por finalidad la revelación de los conocimientos hasta entonces vedados. Esta creencia se encontraba en la mayoría de los textos épicos arcaicos y las escenas donde los fantasmas se muestran ante los vivos. Por ejemplo, en su recorrido por las regiones inferiores por el Hades, Odiseo se encuentra con el espectro de Tiresias, quien poseyera la fama de adivino y fue reconocido por ser el único al que se le concedió el derecho de recordar en el otro mundo lo que había vivido y del cual obtiene valiosa información que le permitirá retornar a su patria:

Una clara señal te daré, bien habrás de entenderla: cuando un día te encuentres al paso con un caminante que te hable del bieldo que llevas al hombro robusto, clava al punto en la tierra tu remo ligero y ofrece al real Posidón sacrificios de reses hermosas, un carnero y un toro, un montés cubiertos de marranas; luego vuelve a tu hogar, donde harás oblación de hecatombes uno a uno a los dioses eternos que pueblan el cielo anchuroso; librado del mar, llegará a ti la muerte, pero blanda y suave, acabada tu vida en la calma de lozana vejez; entretanto tus gentes en torno venturosas serán. Éstas son las verdades que anuncio.

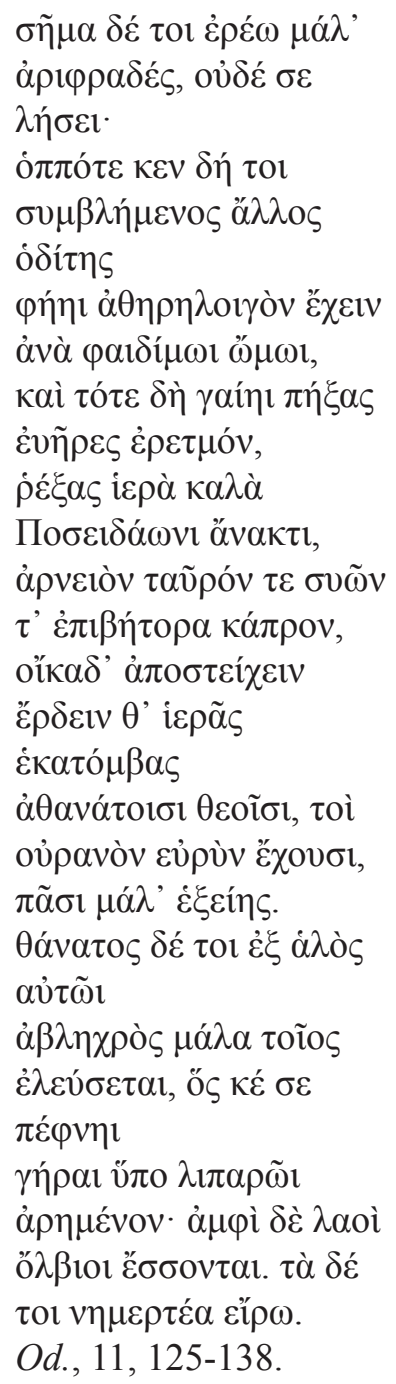

La particularidad de adivinar el futuro o de revelar información valiosa para el héroe también se encuentra en la Eneida, en el momento en que Eneas hace un llamado a las deidades del inframundo y se encuentra con su padre Anquises, quien fue el que le pidió al héroe realizar el viaje al Orco para develarle el porvenir suyo y el de la descendencia de su raza. La invocación a las deidades que imperan en el inframundo es fundamental no solo debido a que esto le permitirá al héroe ingresar a un mundo que 
le es desconocido, sino porque únicamente con el "visto bueno" de estas podrá transmitir el conocimiento que obtenga:

Dioses a quienes cumple el gobierno de las almas y sombras calladas

y Caos y Flegetonte, mudos lugares de la inmensa noche:

pueda yo repetir lo que sé, pueda por vuestro numen

Di, quibus imperium est animarum, umbraeque silentes

et Chaos et Phlegethon, loca nocte tacentia late, sit mihi fas audita loqui, sit numine uestro

pandere res alta terra et caligine mersas. Aen., 6, 264-267.

abrir secretos sepultados en la calígine del fondo de la tierra.

El libro VI presenta la incursión del héroe virgiliano Eneas en el espacio religioso. Pero para poder ingresar es preciso que purifique su espíritu. Esa religiosidad se acrecienta conforme se adentra en las profundidades del Averno, donde irá para encontrarse con su padre Anquises, quien es la sombra del pasado troyano y fungirá como herramienta fundamental y reveladora del destino de la grey troyana, lo cual hace que el héroe se percate de la magnitud de su misión.

Por otra parte, una vez que ha hecho partícipe del futuro a su hijo, Anquises desaparece del texto y con él desaparece simbólicamente toda alusión al pasado, aplastado bajo la preeminencia de un futuro que, a todas luces, beneficiará a Augusto. Ahora nada mantiene a Eneas atado al pasado y la tristeza por la antigua Troya queda atrás. Tampoco se encuentra ligado al recuerdo de su padre. Solo importa una cosa: alcanzar el objetivo de su destino sagrado y ver hacia el futuro, en función del establecimiento de la ciudad que daría origen a la magna Roma. En contraste con el Hades homérico, del que no se dice mucho, Virgilio sí realiza una detallada presentación del Averno como un lugar de sufrimiento y lo dota de ciertas particularidades y espacios destinados para cada uno de las almas que ingresan en él.

En su viaje al Averno, Eneas es guiado por la sacerdotisa de Apolo. Esta lo lleva por los distintos caminos donde transitan las almas, los cuales conforman una jerarquía, ya que -según progresan en su caminar- se van presentando las regiones del inframundo, desde las más terribles y deleznables hasta las más confortables, los Campos Elíseos, caracterizados por ser el mejor lugar donde se puede llegar después de la muerte.

En fin, estando en contacto los espacios más terribles del Averno y con los seres que los habitan, el héroe gana virtud; es decir, frente a los modelos negativos del inframundo, el personaje heroico se posicionará como el ideal por imitar y a su vez, al mostrar las malas conductas y el tormento de una vida postmortem, se convierte en una manera fácil para transmitir el comportamiento ideal para un romano.

Ahora bien, dicho recorrido no podía estar completo sin analizar los pasajes en los que se legitima el poder político de Augusto. En el siguiente apartado se presentan los pasajes en los que Augusto es concatenado al linaje de los dioses y cómo esto cimenta las bases para ostentar un poder incuestionable, pero al mismo tiempo cómo se centra en un intento por retornar a las mores maiorum a las que busca regresar y hacer volver a todos los romanos.

\section{DESCENSUS AD INFEROS: CAMINO HACIA LA LEGITIMACIÓN DEL PODER Y LA INMORTALIDAD DE AUGUSTO}

En el descensus ad inferos de la Eneida es posible distinguir el uso de la prolepsis como eje central de la configuración temporal de la narración, lo cual genera como consecuencia la intercalación del pasado como presente y del presente como futuro, que -a su vez- se integran el uno con el otro a la perfección, en función de un claro sentido legitimador en relación con el poder de Augusto.

A pesar de que las acciones representadas en la Eneida se encuentran enmarcadas en un contexto anterior (in illo tempore) al levantamiento de la ciudad, el desarrollo de estas se desglosa de tal manera que es posible reconocer en muchas de ellas el futuro de Roma, específicamente en la que Augusto y Virgilio vivieron. Un claro ejemplo de tal progresión de las acciones se manifiesta cuando Eneas, una vez que ha llegado donde se encuentra su padre, distingue a sus ancestros: "Aquí la antigua dinastía 
de Teucro, hermosísima prole, / héroes magnánimos nacidos en tiempos mejores, / Ilo y Asáraco y Dárdano el fundador de Troya" ("Hic genus antiquum Teucri, pulcherrima proles, / magnanimi heroes nati melioribus annis, / Ilusque Assaracusque et Troiae Dardanus auctor", Aen., 6. 637-650). Pero sigue su procesión hasta que su padre Anquises le revela con quién finalizará su linaje en el futuro: "Mira cómo llega Marcelo señalado por opimo / botín y vencedor sobresale entre todos los soldados ("Aspice, ut insignis spoliis Marcellus opimis / ingreditur uictorque uiros supereminet omnis", Aen., 6, 854-859). Estos majestuosos hombres harán que el linaje de los ancestros troyanos se perpetúe y se magnifique en la vigorosa ciudad de Roma.

Las almas de los futuros gobernantes únicamente esperan el momento justo para ocupar los cuerpos que les ayuden a alcanzar la grandeza (en este sentido, el cuerpo funciona como instrumento del alma. Un cuerpo fuerte como roble sería el complemento ideal para un alma como la de Augusto o Marcelo) y entre ellos, destacarán Julio César y Augusto Octavio, quienes serán vistos como los herederos más importantes de la sangre divina de Eneas. Según Duque (1950, p. 80) "la visión de Virgilio es clara y definida respecto a la misión divina de fundar un 'Imperio Universal' con esenciales características, y no la de fundar un 'Dominio Universal' de Roma, lo cual, si bien es necesario como punto de partida, no es más que el instrumento de esta misión universalista, que reviste todos los caracteres de una inmensa asociación".

Virgilio no sigue una secuencialidad histórica cuando describe el futuro de Roma, sino que aborda diferentes momentos en la historia de dicha urbs, tal como las pinturas que Eneas observa en el palacio de Dido. Es decir, se pinta con palabras una serie de escenas históricas, solo que -en dicho caso- tales escenas no corresponden a un orden cronológico. Sin embargo, es evidente cómo, mediante el ensalzamiento de los hombres y sus acciones, el poeta de Mantua añade en dicho continuum a la gens Iulia, logrando con esto incorporarla a la historia mítica misma de Roma desde antes de sus inicios y perpetuándola, tomando como base el devenir ininterrumpido de sus generaciones.

Gowing (2005, pp. 17-27) menciona que el principal objetivo del periodo en que Augusto estuvo en el poder fue retomar los valores que existían durante la República y tratar de mantenerlos, así como las tradiciones que esta tenía y poseería futuramente en cuanto que implicaba un nuevo comienzo. No obstante, esto constituía una paradoja, puesto que se aferraba al pasado para iniciar algo nuevo. Para él, los constructos sociales como los ritos, la literatura, las fiestas y otras manifestaciones encontraban asidero en la ideología que intentaba implementar, ya que pretendía exaltar las épocas pasadas como modelo de moralidad para su actualidad, todo esto en función de legitimar su régimen político, social y religioso. Además, el hecho de presentar a los ancestros se reviste de un considerable valor simbólico en el sentido evocador de una nueva política y la configuración de un nuevo régimen, pues le otorga un asidero mítico-simbólico-histórico sobre el cual apoyarse. Unido a lo anterior, para comprender en mayor grado la utilidad de textos como la Eneida, en función de justificar el poder divinal de Augusto y su gens, Gowing (2005) afirma:

Vergil's Aeneid, of course, not only established the divine credentials of the new regime, but also made space, specifically in Book 6 and on the Shield of Aeneas in Book 8, for a survey of memorable characters and moments from the Republic, all part of the ordained plan for Rome. Horace mines Republican history for themes and exempla; even Propertius (but not Tibullus) on occasion drew material from the Republican past. The present typically measures itself against the past. What distinguishes the recollection of the past during the Augustan period from the Republican, however, is the presence of the princeps. Indeed, it becomes seemingly impossible to talk about the heroes of the Republic without prompting, implicitly or explicitly, a comparison with the new emperor (p. 20) $)^{3}$.

3 Traducción propia: La Eneida de Virgilio, por supuesto, no solo estableció las credenciales divinas de un nuevo régimen, sino que también creó el espacio, especialmente en el libro VI y en la descripción del Escudo de Eneas en el libro VIII, basado en un estudio de personajes memorables y momentos de la República, todo parte del plan ordenado por Roma. Horacio obtiene de la historia republicana temas y exempla, incluso Propercio (pero no Tibulo) en ocasiones sacó material de lo republicano. El presente típicamente se mide a sí mismo contra el pasado. Lo que distingue el recuerdo del pasado durante el período de la República de Augusto, sin embargo, es el presente del princeps. En efecto, se hace aparentemente imposible hablar de los héroes de la república sin considerar, implícita o explícitamente, una comparación con el nuevo emperador. 
Este autor manifiesta que las res gestae (Thus in the Res gestae he baldly claims to have preserved for memory many exempla from Rome's past. And certainly many Romans living under the Augustan regime would not have imagined, as we do, that the Republic had "ended", Gowing, 2005, p. 19) testimonian de Augusto, así como de las costumbres ancestrales y las tradiciones sociales deseables para Roma; es decir, que estarán siempre en función de las mores maiorum en tanto muestran los ideales que debe seguir la floreciente ciudad. Además, en función de la descripción que se hace de los hombres preclaros del pasado romano y del futuro, se encuentra el hecho de restituir la pureza romana que se ha perdido con el avance de los siglos.

Le Gall y Le Glay (1995 pp. 35-36) afirman en cuanto a los sentidos de mores maiorum que primero radicaba en un sesgo del espíritu antiguo que, en este punto, se oponía al moderno. Cree este autor-por lo general- en el progreso, material, moral y por ende, político. Por el contrario, los antiguos creían de modo igualmente espontáneo en la degenerabilidad material, sobre todo, en el irremediable agotamiento de la tierra, moral y política. La idea cuadró en el tema literario de la "edad de oro" y llevó en política a otorgar un inmenso prestigio a las antiguas instituciones de la Ciudades-Estado, aunque -en general- hubiera grandes dificultades para situarlas en el tiempo y concretar sus rasgos, hasta el punto de que para los revolucionarios antiguos era normal presentarse como reaccionarios preocupados por reconducir las instituciones a su antigua pureza: en Atenas se había invocado la "constitución de nuestros mayores"; en Esparta, la "Constitución de Licurgo" y entre los romanos, se apelaba al mores maiorum (la costumbre de los ancestros), tal y como Cicerón a menudo exhortaba.

Por su parte, Flower (2010) dice que en el momento en que Augusto se encuentra en el poder, la república de los nobles era una realidad sumamente lejana, casi mítica, que se había perdido debido a la gran cantidad de guerras y violencia con las que transcurrían los días:

The previous traditional republics of the nobiles had by now been lost. As a result there was no agreement about a method for restoring a workable republic, or about how such a republic should look. The increasingly violent interventions by ordinary citizens and soldiers in the political process tended only to weaken, rather than to bolster. In that sense, popular politics was not necessarily "republican" in tendency ( $p$. $30)^{4}$.

Ese periodo tan convulso descartó las posibilidades que existían de establecer nuevamente negociaciones que fortalecieran el régimen republicano por mucho más tiempo y cuya estabilidad no corriera peligro de resquebrajarse.

Así las cosas, Augusto solicita a Virgilio que componga la Eneida, de manera que fuese posible crearla como un mito nacional en la que se ligara a su gens y al pueblo romano, en general, con los más ilustres varones y la sangre olímpica que muchos de ellos poseían, de tal manera que no solo se percataran de formaban parte de un linaje antiquísimo, sino de que debían hacer honor a su estirpe y por lo tanto, debían actuar como sus antepasados lo hicieron. Esa proposición se manifiesta en el momento en que Virgilio hace desfilar a los héroes de Troya y los futuros poseedores de Roma; personajes que debían ser emulados, porque sus virtudes trascenderían en el tiempo.

El primer pasaje del desfile descrito en la Eneida acoge a los reyes que dominarán la ciudad de Alba Longa. Se menciona a Silvio, quien nació luego de la muerte de Eneas, pero que será uno de los más relevantes antepasados romanos, ya que es el primero que ha nacido de la unificación entre troyanos y latinos:
$4 \quad$ Traducción propia. Las repúblicas tradicionales anteriores de los nobles ya se habían perdido. En consecuencia, no hubo acuerdo acerca de un método para restaurar una república viable o sobre cómo se debía buscar una república. Las intervenciones cada vez más violentas de los ciudadanos comunes y los soldados tendieron solo a debilitarse en el proceso político, en lugar de fortalecerse. En ese sentido, la política popular no fue necesariamente "republicana" en la tendencia. 
Aquel joven —es-que Ille, uides, pura iuuenis se apoya sobre el asta qui nititur hasta, pura, proxima sorte tenet luocupa por suertes el cis loca, primus ad aulugar más cercano a la ras aetherias luz, el primero a las auras

etéreas subirá con mezcla de ítala sangre,

Silvio, nombre albano, tu póstuma prole

que, longevo, tarde tu esposa Lavinia

te criará en las selvas, rey y padre de reyes,

de donde nuestra raza dominará en Alba Longa.

Es interesante que se mencione que Silvio será criado por Lavinia en la selva; esto se debía, según lo manifestado por Dionisio de Halicarnaso (Dion. Hal. Ant. Rom., 1. 70. La edición que se sigue es la de Gredos, cuya traducción es realizada por Elvira Jiménez y Ester Sánchez), a que la esposa de Eneas temía que lulo, sucesor de Eneas y primer rey de Alba Longa, tomara represalias contra ella y su hijo. Pero luego de que muriera el primer hijo del héroe troyano, Silvio fue proclamado rey.

Anquises es el encargado (por Virgilio) de manifestar la grandeza de Roma: “„Ah, hijo! Bajos los auspicios de éste aquella ínclita Roma igualará su imperio con las tierras, su espíritu con el Olimpo, y una que es rodeará sus siete alcázares con un muro, bendita por su prole de héroe" ("En huius, nate, auspiciis illa incluta Roma / imperium terris, animos aequabit Olympo, / septemque una sibi muro circumdabit arces, / felix prole uirum". Aen., 6. 781-784) y la dotará de facultad para dominar sobre el resto de las ciudades. Así es como llegará a ser considerada la Caput mundi.

Dichas esas palabras, Anquises otorga la potestad divina a Roma para que esta pueda expandirse en un imperio sine fine amparado en lo establecido con el fatum y legitimado por su estrecha cercanía con los dioses.

Roma tiene todo el derecho, aún más, tiene el deber de imponerse al resto de los poblados del orbe, regirlos bajo su ley, incorporarlos y destruir a todos lo que vayan en contra de su ideología expansionista. Todas las batallas futuras, así como la integración de otros pueblos al imperio, han sido establecidas por el fatum y por lo tanto, todas están justificadas. Si las profecías apuntan al ensalzamiento del princeps, de la gens Iulia y su sistema de dominación, entonces el dominio y la omnipotencia que irradia Augusto se transfundirá también a la patria que regirá.

Un pueblo controlado por un líder, cuyo linaje se puede rastrear hasta los dioses olímpicos, es superior a cualquiera. En consecuencia, los demás deberán respetarlo, pero -sobre todo- obedecerlo. Seguidamente, Virgilio realiza un salto desde la fundación de la ciudad hacia el clímax histórico de esta, que va desde que Augusto se ubica en el poder y termina con el establecimiento de los llamados "siglos dorados" (Ilamada también Edad de oro. Fue una época que inicia luego del triunfo que tuviese Augusto en Actium. No hubo guerras y Roma creció política y económicamente como nunca antes lo había hecho):

Augusto César, hijo del Augustus Caesar, diui divo, que fundará los genus, aurea condet siglos

de oro de nuevo en el Lacio por los campos que un día

gobernara Saturno, y hasta los garamantes $y$ los indos

llevará su imperio; se extiende su tierra allende las estrellas,

allende los caminos del año y del sol, donde Atlante portador del cielo saecula qui rursus Latio regnata per arua

Saturno quondam, super et Garamantas et Indos

proferet imperium; iacet extra sidera tellus,

extra anni solisque uias, ubi caelifer Atlas

axem umero torquet stellis ardentibus aptum. Aen., 6, 792-797. hace girar sobre sus hombros un eje tachonado de lucientes astros. 
Este salto en el orden secuencial del texto y el posterior encomio a la época de Augusto, hacen que Eneas tome consciencia sobre la importancia de cumplir con lo que su destino dicta, ya que él será la base o el tronco inicial que sostendrá el resto de la genealogía en el renacer troyano.

A continuación de dicho pasaje, se da una alternancia en la cual son presentados los héroes que alcanzaron la fama inmortal gracias a sus hechos y la lealtad que poseían por el orden republicano. Por un lado se muestran los gobernantes que tuvo Roma, mientras que por otro son presentadas las familias y descendencias de algunos hombres ilustres que vivieron y participaron activamente durante la República.

El primero al que Virgilio exhibe es a Bruto, quien derrotó a Tarquino y como producto de la victoria decidió instituir el Consulado y quien -ademásserá presentado como exemplum de amor por la patria: "Vencerá el amor de la patria y un ansia de gloria sin medida" ("uincet amor patriae laudumque inmensa cupido", Aen., 6, 823).

Dicho apego por la patria será uno de los componentes esenciales para alcanzar la gloria y la fama inmortal durante la batalla, ya que el héroe accedía a estas por haber entregado su vida en defensa del honor, la grandeza y la libertad de la nación que lo acogió en su seno.

Ese amor por Roma era fundamental para Augusto y sus pretensiones imperialistas, ya que con este se creaba un apego hacia lo nacional y por lo tanto, el asentimiento general hacia todos aquellos proyectos conquistadores que pretendiera. Otro de los que son mostrados, pero esta vez como un héroe que debe escarmentar por la muerte, es Torcuato, lo que le otorga -al igual que a Bruto- un carácter ejemplarizante para las generaciones futuras, precisamente en el instante que se menciona:
No, muchachos, no Ne, pueri, ne tanta aniacostumbréis vuestro mis adsuescite bella ánimo a guerras tan grandes

ni volváis fuerzas poderosas contra las entrañas de la patria,

y tú más, iperdona tú que eres del linaje del Olimpo,

neu patriae ualidas in uiscera uertite uiris;

tuque prior, tu parce, genus qui ducis Olympo,

proice tela manu, sanguis meus!. Aen., 6, 835.

arroja las armas de tu mano, sangre mía!

Esa imagen es fundamental para comprender el valor propagandístico que poseía la Eneida, ya que el hecho de que Torcuato sufra por la guerra hace referencia al más grande de los proyectos de Augusto, el establecimiento del ideal de pax para el pueblo romano: la constitución de un Estado donde las batallas y las victorias aseguren la paz, por mar, por tierra y donde los hijos puedan ver morir a sus padres y no al contrario, como en los tiempos de guerra. Posteriormente, continúa con la descripción de las hazañas de Catón y Cose, a quienes ensalza con características deseables para todo el pueblo romano, como el cultivo de la disciplina y su aplicación en todas las acciones cotidianas. Estos hombres son inolvidables por lo tanto: “¿Quién dejará de nombrarte, gran Catón, o a ti, Coso?" ("Quis te, magne Cato, tacitum aut te, Cosse, relinquat?". Aen., 6. 841). Virgilio es muy atinado al mencionar a esos dos héroes, pues ambos fueron reconocidos también por su frugalidad en todo lo que hacían, cualidad digna de ser estipulada para el resto de los romanos.

Por otra parte, es necesario mencionar que las bataIlas y en fin, todo lo relacionado con lo soldadesco constituyó una manera esencial para la legitimación del dominio romano. El hecho de mostrarse incólume ante el peligro constituía una manera de proporcionar mayor valía al guerrero que -una vez que ha triunfado- sentía una enorme felicidad y un profundo agradecimiento con los dioses.

Así, por ejemplo, en el desfile de héroes, Virgilio no omite mencionar algunos próceres romanos que combatieron contra los cartagineses (los tres grandes opositores de Cartago en las Guerras Púnicas 
fueron Scipión el Africano, Quinto Fabio Máximo y Marcos Claudio Marcelo), entre los que destaca a Marcelo:

Mira cómo llega Marce- Aspice, ut insignis spolo señalado por opimo liis Marcellus opimis

botín y vencedor sobre- ingreditur uictorque uisale entre todos los sol- ros supereminet omnis. dados.

Hic rem Romanam

Éste los intereses de magno turbante tumulRoma en medio de gran tu revuelta

afirmará a caballo, tumsistet eques, sternet Poenos Gallumque rebará a los púnicos y al bellem, galo rebelde, tertiaque arma patri susy colgará el tercero al pendet capta Quirino. padre Quirino las armas Aen., 6, 855-859. capturadas.

Al recurrir a Marcelo, último de los comandantes romanos, Virgilio, en voz de Anquises, proyecta una línea generacional que va más allá del propio Augusto, lo cual hace que Eneas considere aún más necesario cumplir con la misión de fundar la ciudad.

Es posible que, al mostrar a todos esos personajes, Virgilio no pretendiera ensalzar las hazañas de cada uno, es decir, como individuo o como mera presentación de estos. Al contrario, pretendía hacer notar el conjunto de hombres ilustres de Roma y mostrar los ideales que todos los romanos debían igualar.

Son enumerados de tal manera que pueden establecerse características en común, aunque distan temporalmente los unos de los otros; sin embargo, el desfile de tales personajes heroicos es la señal de inmutabilidad de estos y de la ciudad, y de que desde Eneas hasta Augusto existió un compromiso con el destino romano, lo cual da legitimidad al poder de este último.

El descensus ad inferos no solo se convierte en un medio de legitimación política por medio del cual se justificaba el poder que ostentaría Augusto durante su mandato, sino que la relación del emperador con la muerte simbólica experimentada por Eneas con la catábasis lo llevará a alcanzar uno de sus más anhelados objetivos: la inmortalidad y la perpetuidad de su memoria y su familia.

Dicha relación entre Eneas, su catábasis y Augusto da comienzo en el instante en el que Anquises, padre del héroe troyano, le hace ver a su hijo -a manera de un desfile- la insigne progenie que poseerá. Virgilio pone en boca de Anquises el anuncio de que, al igual que Eneas será divinizado y ocupará un lugar en el Olimpo. Sus descendientes, de la misma manera que él, serán elevados a tal condición o al menos, serán catasterizados (se llama catasterismo a la trasformación de un personaje en una estrella). Es de esta manera que se procede a la legitimación de la familia a la que se atribuía la descendencia directa del héroe troyano como condición prístina, es decir, la gens Iulia, que gobernaría Roma ostentando el poder imperial por mucho tiempo.

Teniendo en cuenta que la Eneida se caracteriza por presentar de manera imbricada múltiples temporalidades, lo correspondiente a la divinización de Eneas hace referencia a los hechos principalmente de orden político y religioso que resultarán tanto en la divinización de César como en la estructuración postrera del culto imperial. De este modo, el fatum de la Eneida se congracia con Eneas, Julio César y Augusto, y les promete la bienaventuranza de la superación de la muerte y la promoción al Olimpo.

Para complementar, en cuanto a la relación de Augusto con la muerte y su búsqueda de inmortalidad habrá que aproximarse al tiempo en que la Eneida fue redactada. En el momento en que dicho texto fue iniciado por Virgilio, la apoteosis de César no era un hecho muy lejano, lo que quiere decir que estaba aún vivo en la memoria de los romanos. Desde el punto de vista político, la apoteosis, más que un bien al muerto, beneficiaría al emperador vivo que -en algunos casos- buscaba legitimidad en la memoria del antecesor. La consagración, además de poseer un tono político, era sobre todo un instrumento de memoria y propaganda de la imagen imperial.

Esto hace pensar que el poeta mantuano no podía pasarlo por alto y más bien retome dicha consagración para ponerla al servicio de los fines de Augusto. En una de las pocas veces que es mencionado en la Eneida, César es mostrado como un ser absolutamente divino, tanto por sus hazañas como por 
llevar en sus venas la sangre divina de Eneas y la de su madre Venus, y dicha condición es proyectada hacia su hijo adoptivo, Octavio Augusto. Dicha aparición de César se encuentra estrechamente ligada a la narrativa del descensus ad inferos que se ha tratado en este capítulo, específicamente en las profecías de Anquises quien, encontrándose en los Campos Elíseos, empieza a nombrar y a hacer pasar delante de su hijo a todos los varones ilustres de Roma que conformarán su descendencia. La voz profética de Anquises le anuncia su porvenir, trayendo a la palestra varios trozos de la historia romana de distintos periodos, desde la fundación y hasta lo principal de la configuración del imperio y su porvenir, como es el caso de Octavio Augusto y Marcelo, sobrino del princeps.

En ese desfile de renombrados varones, Augusto es designado como parte de la progenie de lulo, héroe prometido e hijo de un divinizado del imperio, lo cual lo proyecta como ser al que hay que venerar, tal como se muestra en la siguiente cita del acápite 785:

Vuelve hacia aquí tus ojos, mira este pueblo

y a tus romanos. Aquí, César y toda de Julo

la progenie que ha de llegar bajo el gran eje del cielo.

Éste es, éste es el hombre que a menudo escuchas te ha sido prometido,

Augusto César, hijo del divo, que fundará los siglos

de oro de nuevo en el Lacio por los campos que un día

gobernara Saturno.

Así las cosas, en consonancia con la profecía presentada por Júpiter a Venus en el libro I de la Eneida, los versos anteriores se complementan y se unifica la temporalidad mítica que permite la acción textual con el futuro predicho, desvaneciendo de una vez por todas cualquier barrera generacional. Es decir, lulo, hijo del héroe troyano es recordado en la misma estrofa que nombra su gens divina. César es elevado a la condición de divinidad y Augusto surge como aquel destinado a devolver en el Lacio los siglos dorados, una nueva edad de oro marcada por la cercanía entre los hombres y las divinidades, la ausencia de labores bélicas, la seguridad y la prosperidad, edad de oro que coincide -desde el punto de vista mítico- con el reinado de Saturno en Lacio. Augusto ascenderá a los cielos prometidos o referenciados en la jornada por el más allá realizada por Eneas. Sus restos serán depositados en un mausoleo magnificente, que se tornará en un santuario dada su condición divina, lugar de memoria por excelencia, en el que se unificarán la ancestralidad de Eneas, los hechos preponderantes de César y el homenaje a sí mismo.

Virgilio pone la divinización de los hombres preclaros de Roma en las profecías dadas en el inframundo, con lo que directamente apunta a la declaración de Augusto como uno más de los inmortales. Así, igual que sus ancestros divinos -Eneas y Rómulo- Augusto gana un espacio junto a las demás divinidades del Olimpo y triunfa en la batalla contra la muerte y el olvido.

\section{CONCLUSIONES}

El constante contacto con los muertos hace que, en la Eneida, el mundo de los muertos y el de los vivos no se excluyan simultáneamente. Más bien, existe una dependencia entre estos, ya que los muertos requieren de los vivos para que los ritos funerarios sean dispuestos de manera más atenta y su memoria pueda perdurar a lo largo del tiempo. Mientras, los vivos recurren a dicha memoria en busca de consejo. En ese sentido, el más allá es un lugar donde las almas no llegan como sombras vacías y desmemoriadas, sino que en la Eneida es un sitio donde las almas cumplen con una función reveladora y legitimadora del poder que Roma tendrá a lo largo de las generaciones.

Uno de los aspectos más importante que se concluyen sobre la importancia del Averno en la Eneida es que estando en contacto los espacios más terribles de este y con los seres que los habitan, el héroe gana virtud. Es decir, frente a los modelos negativos del inframundo, el personaje heroico se posicionará como el modelo a imitar. Eneas es el personaje ideal capaz de ir al más alláy retornar como un héroe. Con el descensus ad inferos se establece finalmente el lazo entre Eneas y Augusto, hecho que le proporcionará al princeps características heroicas y, por supuesto, divinas. Estas mismas lo ayudarán 
a convertirse en uno de los uiris ilustribus de la mítica y omnipotente Roma. Además, con dicho descenso, las virtudes de Eneas se acrecientan, debido al contraste entre él y quienes se encuentran condenados a sufrir en el Orco, hecho comparable a Augusto, quien se engalana y se glorifica a partir del recuerdo de sus antepasados. Las promesas de divinización de Eneas y toda su descendencia se encuentran engarzadas en el devenir del texto y le atribuye a la gens Iulia, a la que pertenece Augusto, la legitimización de carácter divino y ancestral.

\section{REFERENCIAS BIBLIOGRÁFICAS}

Abascal Palazón, J.M. (1991). La muerte en Roma: fuentes, legislación y evidencias arqueológicas. En Arqueología de la muerte: metodología y perspectivas actuales. [Publicado previamente en: D. Vaquerizo (coord.), Arqueología de la muerte: metodología y perspectivas actuales, Fuenteobejuna 1990, Córdoba 1991, 205-245].

Albiac, G. (1996). Muerte: Metáforas, mitologías, símbolos. Buenos Aires: Paidós.

Blázquez, J.M., Martínez-Pinna, J. y Montero, S. (1993). Historia de las religiones antiguas: Oriente, Grecia y Roma. Madrid: Cátedra.

Campbell, J. (2008). Psicoanálisis del mito heroico. México D.F.: Fondo de Cultura Económica.

Cumont, F. (1957). The Oriental Religions in Roman Paganism. New York: Dover Press.

Chevalier, J. y Gheerbrant. A. (2009). Diccionario de Símbolos. Madrid: Herder.

Duque, Á. M. (1950). La política de estado universal en César Augusto a través de la "Eneida" de Virgilio. Revista de Estudios Políticos, 53, 57-98.

Eliade, M. (1960). El chamanismo y las técnicas arcaicas del éxtasis. México: Fondo de Cultura Económica.

Eliade, M. (2001). Nacimiento y renacimiento. El significado de la iniciación en la cultura humana. Barcelona: Kairós.

Eliade, M. (2007). Mito del eterno retorno. Barcelona: Kairós.
Felton, D. (2007). The Dead. En: Ogden, D. (2007). A Companion to Greek Religion. Oxford: Blackwell.

Flower, H. (2010). Roman Republics. New Jersey: Princeton University Press.

González, P. (1999). Catábasis y resurrección. Espacio, Tiempo y Forma, II, 12, 29-79.

Gowing, A. M. (2005). Empire and Memory. The representation of the Roman Republic in Imperial Culture. Cambridge: University Press.

Grimal, P. (2008). Diccionario de Mitología griega y romana. Madrid: Paidós.

Le Gall, J. y Le Glay, M. (1995). El imperio Romano. El Alto Imperio, desde la Batalla de Actium hasta la Muerte de Severo Alejandro (31 a.C. a 245 d.C.). Madrid: Akal. Recuperado de http:// www.kilibro.com/book/preview/25564_el-imperio-romano.

Liddell-Scott-Jones. (1992). Greek-English lexicon. California: University of California Press.

Minois, A. (2005). La historia de los infiernos. Madrid. Paidós.

Morales Harley, R. (2012). La katábasis como categoría mítica en el mundo greco-latino. Revista Káñina, Rev. Artes y Letras, XXXVI, 127-138.

Raimbault, G. (1996). La muerte de un hijo. Buenos Aires: Nueva Visión.

Rhode, E. (2009). Psique: La idea del alma y la inmortalidad entre los griegos. Madrid: Fondo de Cultura Económica de España.

Sevilla, A. (2012). Morir ante suum diem: la infancia en Roma a través de la muerte. En Niños en la Antigüedad: Estudios sobre la infancia en el Mediterráneo Antiguo. Zaragoza: Editorial de la Universidad de Zaragoza.

Toynbee, J.M.C. (1996). Death and burial in the roman world. London: Thamer and Hudson.

Virgilio. (1990). La Eneida (Rafael Fontán Barreiro, Introducción y traducción). Madrid: Alianza.

Virgilio. (2010). Obras completas. Eneida, Geórgicas, Bucólicas y Apendix. Madrid: Cátedra. 


\section{La écfrasis metaléptica: recurso representacional en Una novelista en el Museo del Louvre, de Zoé Valdés ${ }^{1}$}

Por: Magíster Iraida L. Bárzaga Morales², Universidad de Concepción, Chile

Recibido: 8 de diciembre, 2017.

Aprobado: 12 de marzo, 2018.

\section{Resumen}

Con este trabajo se pretende demostrar que la novela Una novelista en el Museo del Louvre (2009) está estructurada a partir del recurso retórico e intertextual "écfrasis metaléptica", categoría acuñada por Luz Aurora Pimentel (2012), que configura una distribución museográfica en la que el relato se construye como guion, para desacralizar el discurso político insular y, a la vez, instalar la novela, en su doble plástico y narrativo, como discursos insurrectos y críticos del status quo cubano. La relación intertextual o intermedial establecida entre la representación literaria y la visual, entonces, es de carácter contributivo, porque las imágenes que se evocan mediante la escritura se transforman en iconotextos que incrementan el valor icónico del discurso.

\section{Abstract:}

The ekphrasis metaleptica: representational resource in Una novelista en el Museo del Louvre, of Zoé Valdés

With this work we intend to demonstrate that the novel Una novelista en el Museo del Louvre (2009) is structured from the rhetorical and intertextual resource "ekphrasis metaleptica", category coined by Luz Aurora Pimentel (2012); that configures a museographic distribution in which the story is constructed as a script, to desacralize the insular political discourse, while installing the novel, in its plastic and narrative double, as insurrectionary discourses and critics of the Cuban status quo. The intertextual or intermedial relation established between the literary and visual representation, then, is of a contributory nature because the images that are evoked through writing are transformed into iconotexts that increase the iconic value of the discourse.

1 Este trabajo forma parte de una investigación mayor denominada "Apuntes sobre la dimensión museal de la literatura latinoamericana o los museos de papel" (Proyecto FONDECYT $\mathrm{N}^{\circ} 11121221$ ), cuyo investigador responsable es el Dr. Juan D. Cid Hidalgo.

2 Iraida Bárzaga es Magíster en Literaturas Hispánicas, graduada en la Universidad de Concepción, Chile. Actualmente es investigadora FONDECYT y estudiante del Doctorado en Literaturas Latinoamericanas en la Universidad de Concepción, Chile. Contacto: irabm1987@ gmail.com.

PALABRAS CLAVE:

Écfrasis metaléptica, intertextual, intermedial, iconotextual, recurso representacional, guion museográfico, curadora

\section{KEY WORDS:}

Ekphrasis metaleptica, intertextual, intermedial, iconotextual, representational resource, museographic script, curator 


\section{INTRODUCCIÓN}

En los últimos tiempos, están siendo visibles diversos análisis que asumen la écfrasis como recurso intertextual que atraviesa la escritura de múltiples autores. Sin embargo, el origen de esta forma retórica data de tiempos primigenios. En esta investigación se emplea el término "écfrasis", que es uno de los usos aceptados en castellano. Pero, es común encontrar también el término "ecfrasis" sin tilde en castellano y en inglés "ekphrasis" o "ékphrasis", siendo este último el que posee mayor similitud con el vocablo griego original "Éxффoorı". El término fue acuñado por vez primera en los Progymnasmata de los siglos I al IV d.C., donde se consideraba como una descripción-narración sobre cualquier tema que tenía la virtud vívida de poner el objeto frente a los ojos. Es decir, dotaba de vida al relato, acercando al lector para crear una imagen visual de manera que produjera en él el mismo efecto que si estuviera ante el original. Estas descripciones vívidas con el paso de los años se dispusieron en torno a objetos plásticos de carácter figurativo, de modo que en las teorías literarias contemporáneas el concepto se circunscribió solamente a la descripción de objetos de artes visuales en literatura (para mayores antecedentes se recomienda el reciente trabajo de Begoña Alberdi, "Escribir la imagen: la literatura a través de la écfrasis" en Literatura y Lingüística $N^{\circ} 33$, pp. 17-38). Es en este marco que se inscribe esta investigación que pretende dar cuenta de los recursos narrativos empleados por la escritora cubana Zoé Valdés en Una novelista en el Museo del Louvre (2009) [a partir de aquí, cuando se cite de la novela objeto de estudio Una novelista en el Museo del Louvre, solo se colocará el número de la página y no la ficha completa].

La crítica académica no ha reparado de manera constante sobre la obra de esta autora y menos aún, sobre este relato, solo en determinados momentos y en textos muy puntuales, lo cual no significa que sus creaciones carezcan de méritos y en ellas no aparezcan reflejados recursos que cautiven a los lectores. Con estas páginas se pretende revelar el proyecto narrativo de la escritora cubana desde una mirada crítica a dicha labor. En este intento por escudriñar los elementos composicionales, los argumentos y los "secretos" de la novela, se busca reflexionar sobre algunas formas posibles de entendimiento entre lo plástico y lo literario, línea de acceso que se inscribe en los centros de interés de la intermedialidad, iconotextualidad, intertextualidad; todos ellas herramientas a las que se recurre en el análisis de "lo plástico" en la novela.

Zoé Valdés se apropia del recurso ecfrástico para desplegar su proceso escritural dinámico con lo que establece una especie de juego a partir de la ficción plástica aludida. Para analizar la poética empleada por la autora en la novela objeto de estudio se asume este recurso como configurador de la trama narrativa, la que a su vez constituye una verdadera invitación a una lectura iconotextual que dota de múltiples resignificaciones e interpretaciones a la novela. Con respecto a esto, vale destacar que la descripción narrativa de cuadros plásticos dinamiza las redes de referencia del lector, el cual se ve en la necesidad de proyectar mucho de su acervo en el acto de lectura. Dinámica en la cual los personajes de las obras de arte transgreden la frontera del contexto que los define, lo que provoca que se subvierta el estatuto canónico de las figuras que protagonizan las obras de artes visuales, de los personajes y de la narradora.

El intertexto, a través de una forma de écfrasis (écfrasis metaléptica), atraviesa el discurso de esta narración y desempeña un rol esencial en ella. La écfrasis es perceptible -entonces- como registro "tasador" de la ficción que subvierte el estatuto canónico de los personajes y las figuras de artes visuales citadas, creando espacios de representación literaria con los cuales el lector es deleitado, a la vez que puesto en un rol "creativo", pues comparte la focalización del narrador, quien se encuentra curatoriando una exposición: la novela. Desde su posición de narradora exiliada, la novelista remite a la idea de identidad diaspórica junto a la elaboración de un discurso de fuerte sentido feminista. Líneas temáticas que son recurrentes, aunque de manera solapada, en la prolífera obra literaria de Valdés. Por ende, la pregunta de investigación que guiará esta propuesta es la siguiente: ¿Qué importancia tiene el empleo de la écfrasis metaléptica en el despliegue de la novela que inventarea una serie de obras plásticas universales? 
Con esta propuesta investigativa se busca poner en valor la escritura de la novelista cubana-española Zoé Valdés, demostrar que el relato se construye fundamentalmente a través de écfrasis metaléptica, que inscribe el proyecto narrativo en una interzona en que arte y literatura despliegan diálogos y relaciones de enorme interés.

Este estudio académico a Una novelista en el Museo del Louvre, como se ha señalado, centra su atención en la representación verbal de obras de artes visuales, es decir, en el recurso retórico-discursivo denominado écfrasis metaléptica, entendido como configurador de una escritura que privilegia las relaciones intertextuales o intermediales que se establecen entre ambas representaciones, a la vez que explicitar su carácter productivo, ya que las imágenes evocadas se convierten en iconotextos, con lo cual se establece una férrea, intensa y fuerte relación que produce un incremento icónico. En las siguientes páginas se pretende acercar al lector a una nueva línea de acceso a la escritura de Zoé Valdés, que viene a complementar las lecturas parciales desde la perspectiva de género, la condición exiliar y la búsqueda identitaria.

\section{LOS OJOS DE LA PALABRA: APROXIMACIONES AL CONCEPTO DE ÉCFRASIS}

La preocupación de la literatura por "presentar una descripción-narración sobre cualquier tema que tenía la virtud vívida de poner el objeto frente a los ojos" (Pimentel, 2003, p. 281) se percibió desde la cultura helenística. Es en este contexto que se acuñó la palabra écfrasis (ekphrasis), término griego que "en su sentido etimológico significa la acción propia de hacer comunicable o de facilitar el acceso y el acercamiento a algo" (Agudelo, 2012, p. 72); de manera que la descripción de una escena o de un objeto tenía como finalidad hacer evidente con palabras aquello que estaba ausente.

Entre 1711 y 1714, la descripción del escudo de Aquiles, realizada por Pope, constituyó la primera écfrasis de la cual se tuvo referencias en la historia de la literatura debido a la maestría con la que fue descrito, que fue "pintado" en las líneas del poema épico sin tener existencia real. La investigadora Ana Lía Gabrieloni (destacada investigadora, profesora y crítica literaria argentina, miembro del Centro Interdisciplinario de Estudios Europeos en Humanidades (CIEHUM), que ha realizado diversos estudios vinculados a la relación entre la literatura y las artes visuales), expone: "la primera écfrasis que conocemos en la historia de la literatura dejó de presentarse exclusivamente como un escudo-cuadro-monumento para estar revestida con características de documento" (2008, p. 86).

Por otro lado, en la tradición grecolatina, especialmente la desarrollada por los progymnasmata o ejercicios de retórica para entrenar a los alumnos en la práctica de la escritura, la écfrasis quedó definida como "una descripción extendida, detallada, vívida, que permitía presentar el objeto ante los ojos; una descripción que tenía la virtud de la enargeia" (Pimentel, 2003, p. 205). Es decir, los maestros griegos de retórica enseñaban y empleaban la écfrasis como un ejercicio a través del cual se describía un objeto, una persona o un lugar de forma precisa y muy detallada, de tal manera que el oyente creyera estar ante él.

Tomando en consideración lo enunciado, es perceptible que la écfrasis -en este contexto antiguotenía como rasgo principal atribuirle vida y movilidad al relato, haciendo más asequible la lectura en tanto el lector fuese capaz de crear una imagen visual a partir de lo interpretado. Con el paso del tiempo y la llegada de la modernidad, estas descripciones vívidas se fueron extendiendo a obras de artes figurativas, siendo los objetos la esencia de la descripción, mientras que las acciones en sí mismas conformaban la narración.

Hacia mediados del siglo XX, el vasto pasado retórico de esta figura sufrió una profunda reinterpretación con la teoría de Leo Spitzer (1962), donde plantea que "la écfrasis es la descripción poética de una obra de arte pictórica o escultórica" (p. 72). A partir de esta interpretación, en el 2003 Pimentel plantea que la écfrasis adquirió el carácter de género literario y algunos años más tarde, Murray Krieger (1967) la eleva a un principio general de la poética.

En las últimas décadas se ha podido notar una abundante reflexión acerca de la lectura de las imágenes en una era mediática, donde se ha instalado 
la primacía de la mirada (Mitchell, Barthes, Eco, Greimas, Panofsky, Praz, Gali). Es por ello que se considera necesario y productivo:

Constatar las relaciones entre novela y artes visuales que nos llevan a interrogar las fronteras y fisuras que van de la imagen al texto y viceversa, es decir, con qué mecanismos se enriquecen, alteran o se matizan los elementos visuales al invadir el campo textual y cómo se vuelcan los ingredientes textuales en el espacio visual (Cid, 2016, p. 2).

En este recorrido por los autores que han contribuido a la discusión sobre la écfrasis y las relaciones entre literatura y artes plásticas o visuales, es necesario recurrir a Heffernan -citado por Pimentel- al referirse a la definición de écfrasis y enuncia que "de manera un tanto más abstracta la écfrasis es para Heffernan la representación verbal de una representación visual" (Pimentel, 2003, p. 206) y que resulta muy difícil imaginar una historia del arte desprovista de composiciones ecfrásticas, esto es, sin representaciones verbales de otras representaciones, las visuales, que constituyen el objeto de estudio de dicha historia. Años después, Clüver (1997), refiriéndose a la écfrasis, expuso que es "la representación verbal de un texto real o ficticio compuesto en un sistema sígnico no verbal" (p. 26). Es notorio que estos autores destacan el sentido representacional del proceso ecfrástico, de modo que si el texto verbal asume la representación de un objeto de artes visuales, entonces se establece una relación intertextual. Si se entiende la intertextualidad, en este sentido, como una representación verbal de una representación visual, Wagner (1996) planteó que se forma una "relación de intermedialidad" (p. 17). Pimentel añadirá al respecto:

La relación intermedial pone en juego por lo menos dos medios de significación y de representación. En el caso del objeto plástico citado; en su relación con el texto verbal la imagen evocada puede desembocar en un verdadero iconotexto: no solo la representación verbal es leída/escrita - de hecho descrita - como texto, sino que al entrar en relaciones significantes con el verbal le añade a este último formas de significación sintética que son del orden de lo icónico y de lo plástico - de hecho una suerte de incremento icónico -, construyendo un texto complejo en el que no se puede separar lo verbal de lo visual: un iconotexto (2012, p. 309).

En la actualidad la écfrasis desestabiliza las rígidas divisiones entre la literatura y las artes visuales, desarrollando un doble carácter intertextual, debido a que representa un objeto de otro medio de expresión y a la vez, se apropia de terminologías y conceptos descriptivos que pertenecen a la historia del arte como disciplina.

Elsner (2002) por su parte, propuso desplazar la definición de écfrasis, que se consideraba canónica en la modernidad, para entenderla como "la representación verbal de una representación visual" (p. 12). Dicha propuesta amplía el campo aplicativo de esta categoría, haciéndola extensiva no solo a la literatura, la poética, la historia del arte y la crítica, sino a las prácticas culturales. En concordancia con esta idea, es interesante destacar que, si se analiza la écfrasis como práctica cultural, entonces las imágenes pueden leerse como si fueran textos y los textos como si fueran imágenes (Schneck, 1999).

Continuando con esta visión interartística de la écfrasis, es necesario hacer una aproximación a los fundamentos señalados recientemente por Ponce Cárdenas (2014). Tomando como objetos de estudio poemas españoles contemporáneos consagrados a la evocación de una pintura concreta, este académico realiza un recorrido visual y verbal a través de los géneros: naturaleza muerta, paisaje, retrato, escenas de costumbre y pintura histórica, para que el lector pueda entablar un diálogo entre el texto literario y las fuentes icónicas, lo cual es posible estéticamente a través de la écfrasis.

Luego de enunciar los matices que presenta la relación texto/imagen, introduce un análisis de lo que ha Ilamado "pinacoteca verbal" (Ponce, 2014, p. 27), que es en esencia la manera en la que está dispuesto y organizado el texto estructuralmente, la forma en que se encuentra montada la novela y la manera en que se inserta el corpus de obras seleccionadas. "Una vez seleccionados los cuadros que 
se van a evocar por medio de la transposición de arte, el poeta debe decidir cuál va a ser la organización, la arquitectura textual del volumen concebido como una suerte de pinacoteca en verso" (Ponce, 2014 , p. 27). Desde este enfoque se puede interpretar que el autor de textos ecfrásticos asume un doble rol: se convierte en curador de obras de artes visuales y escritor de un texto literario. Con ello el crítico enfatiza que "La dispositio del poemario se constituye en reflejo verbal de la organización propia de un museo o una colección" (Ponce, 2014, p. 28), a la vez que propone comprender el texto ecfrástico a partir de una organización museográfica. Vale destacar que el curador es un investigador o un estudioso que entre sus funciones tiene el poder legitimador de obras de arte. Puede imponer obras, nombres y técnicas, seleccionar obras, dar forma al catálogo, dialogar y negociar con los patrocinadores y otros. El curador crea su propia obra (la muestra) a partir de obras existentes.

Por último, Pimentel (2012) definió la écfrasis metaléptica, categoría que rige este análisis literario, como el desborde del impulso plástico y las transgresiones del nivel narrativo al que pertenece. Los personajes del cuadro descrito se animan y salen del marco que delimita su existencia ficcional como objetos plásticos para interactuar con el otro mundo ficcional del cual, supuestamente, eran solo ornamento.

\section{INTERTEXTUALIDAD (INTERMEDIALIDAD)}

Una novelista en el Museo del Louvre es una novela que establece una interesante y recíproca relación entre palabras e imágenes. Las obras de arte -a diferencia de lo que pudiera pensarse- aquí no son empleadas para ilustrar la escritura, sino que sucede todo lo contrario; puede asumirse que el lenguaje visual es el detonante de una narratividad sui generis, causa principal -a modo de ver de quien escribe- por la cual dicha novela no ha sido analizada desde ninguna perspectiva por la crítica literaria. En ella, ambas expresiones de las artes se complementan y se potencian, entregando a medida que avanza la trama una lectura que -más allá de la hibridez e intertextualidad explícitas- se torna cada vez más sugestiva, dinámica e instructiva, debido a las múltiples posibilidades interpretativas que despliega. En adelante se demostrará que la relación "tanto referencial como representacional con un objeto plástico que el propio texto propone como autónomo, como otro con respecto al discurso que intenta representarlo" (Pimentel, 2003, p. 285) induce a una lectura iconotextual.

La intertextualidad es el mecanismo principal a partir del cual se configura la écfrasis, siendo de vital importancia en la tradición literaria. La écfrasis literaria se basa en una idea previa de la obra artística, en un supuesto, en lugares comunes o juicios de valor a propósito del artista, ya existentes y establece una relación contextual al hacer que las obras de arte participen del entramado discursivo.

La novela de Valdés es concebida como un relato intertextual en varios niveles. Este carácter no solo es notorio por el empleo constante del recurso ecfrástico, sino además porque la autora -inspirada en el legado de su autor favorito, Manuel Mujica Láinez (1910-1984), y con el propósito de rendirle tributo- desde el propio título de su novela establece diálogo con el libro de cuentos del escritor argentino Un novelista en el Museo del Prado (1984); indicio este que condiciona la lectura posterior, a la vez que amplía el corpus de textos que ponen en tensión el mundo plástico y el literario.

Ahora bien, en el plano analítico la écfrasis facilita a la autora confeccionar una obra ficcional en la cual la alusión cumple un papel fundamental, en tanto la vincula con el propósito clásico de atribuir al lenguaje literario la capacidad de "hacer ver" obras de arte con una finalidad que supera los límites del relato novelesco. Pero no es "hacer ver" en su sentido literal, sino desde un enfoque utilitario que posibilita una toma de posición política, inclusive con aquellas problemáticas propias del ser cubano. En correspondencia con la propuesta de Michael Riffaterre (2000), se tendría que señalar que las obras de arte aludidas como parte del decorado también tienen una función simbólica que incluso motiva actos y emociones que van desplegando la novela en un juego interartístico.

Como se puede apreciar, el ejercicio escritural de Valdés se construye sobre esta base teórica, pues pone en correlación dos medios de significación 
y representación a partir de la cita de varias obras importantes en la historia del arte universal reunidas en este reconocido museo. En la relación entre las obras citadas y el texto literario, los cuadros se convierten en "iconotextos" (Wagner, 1996) que invitan al lector a realizar, por lo tanto, una lectura iconotextual. En este entorno la autora se sirve de la écfrasis como recurso de aproximación a la imagen, de la que se apropia creativamente y la pone al servicio de los fines propiamente literarios que subyacen a la estetización de la práctica argumentativa, logrando que la descripción de las obras de artes visuales no solo pueda leerse como texto, sino que le atribuye significaciones de carácter icónico y plástico al texto verbal. Así, ambos textos son inseparables y "la écfrasis participa de una verdadera búsqueda ilusionista. Un ilusionismo que, añadamos aquí, participa de la vocación representacional, tanto de la literatura como de la pintura" (Giraldo, 2015, p. 205).

La historia se desencadena a partir de la visita que realiza la novelista (voz narrativa) al prestigioso Museo del Louvre. Tras ser perseguida por el guardián de la institución, persuadiéndola de que estaba cerrado, ella cae y se golpea la cabeza; detalle que condiciona el desarrollo del relato y certifica que -aun cuando la novela en su concepción general es postmoderna- la autora se vale de esta aplicación característica de la literatura modernista para evadir la realidad, para escapar de las circunstancias espacio-temporales que atravesaba y poder desplegar su escritura. Valdés (2009) escribe: "nunca más he podido salir del Museo del Louvre desde entonces; desde el año 1983 resido y convivo con los espectros dibujados o cincelados" (p. 17). A partir de este momento, la novelista -o en su defecto el yo narrador- queda atrapada en el interior del museo y se transforma en testigo y protagonista de lo que sucede con las obras de arte distribuidas en las distintas colecciones y salas del Louvre. Otro indicio importante es el referente al año, que atribuye cierto sentido autobiográfico al relato, debido a que desde 1983 Valdés residió en la capital francesa en calidad de técnica de la Oficina Cultural de Cuba en la UNESCO y como digna admiradora de los museos en general, en este caso particular, del Museo del Louvre, asume la fecha del primer año que residió fuera de la isla para situar su discurso narrativo. A pesar de que en este punto la lectura es muy incipiente y aun no se alcanza a tener claridad de lo que sucederá en las páginas siguientes, sí es evidente que la escritura estará mediada por la relación texto/imagen cuando la escritora expone:

Durante veinticinco horas o veinticinco años, en fin, durante este tiempo literario; no sólo he visto las obras de arte del Museo del Louvre resistir durante el día, enmarcadas en sus cuadros, o inmóviles encima de los pedestales, aguantando ecuánimes exclamaciones de admiración o sonrisas irónicas hasta el aburrimiento, también han aguardado impasibles que los estudiantes las copien, y que los estudiosos se atrevan a acercarse con sus lupas, a criticar sus grietas, los desperfectos de una nariz, la ambigüedad de una sonrisa (p. 17).

Desde esta perspectiva, se va configurando la trama narratológica. La autora asume el rol de curadora de obras de artes visuales, realiza una selección acorde con sus intereses y crea a partir de esta colección general una colección alternativa o -en términos de Ponce Cárdenas- una "pinacoteca verbal". Es decir, establece una especie de juego de caja china, con el cual le atribuye a la novela el principio curatorial de una exposición. Entonces, se puede plantear que a partir de la visualidad que propone el texto literario, por un lado, contribuye a la idea de que las obras perduren no solo en su soporte físico, sino también a partir del lenguaje y por otro lado, los lectores asumen una dualidad de condición, se transforman en receptores de obras de arte. En adelante, se tratará de dilucidar los posibles propósitos que indujeron a la novelista cubana a estructurar su obra partiendo de una distribución museográfica en que la novela se construye como guion.

Este sugerente texto transgrede los límites entre la ficción y la realidad para poner en conocimientos del lector temáticas que están vinculadas a la vida de la autora: el exilio, los asuntos de género y la añoranza por su territorio originario. Estas preocupaciones las trabaja, entonces, en un contexto bien particular, en el museo, que asume -como señala Juan D. Cid Hidalgo- el carácter de dispositivo. En 
"Archivo y novela. Sobre la dimensión museal de la literatura latinoamericana" (2017) el crítico sostiene que "el museo comienza así a consagrarse como un dispositivo que selecciona, reúne, conserva, hospeda y sanciona aquello que culturalmente es valioso y que forma parte de lo que es definido como patrimonio inmaterial" (Cid, 2017a, p. 172).

La novela no busca representar las obras mediante el lenguaje verbal porque, en concordancia con lo planteado por Mitchell (1994), el lenguaje significa sin imitar, sino que se centra en construir un mundo ficcional denso, es decir, un mundo que asume la obra de arte para configurar un espacio interzona. $\mathrm{Al}$ modo borgeano, la narradora introduce elementos verosímiles para convencer y hacer parte de su historia al narratorio.

Los usos del lenguaje insertan al lector en un mundo fascinante, en el cual confluyen personajes de diversas épocas sociohistóricas que -salidos de los límites de las obras de arte universales- cobran autonomía, actividad que quiebra todo horizonte razonable de expectativas. Rodríguez (2009) señala: "he aquí una Zoé Valdés catárquica en lo estilístico, con un aplomo literario exquisito, atrevida incluso a jugar con el lenguaje según el cuadro y la época en cuestión en la que se sumerge" (online). Aun cuando pareciera que la trama carece de continuidad debido a que no narra una sola historia, ya que cada capítulo desde su propio subtítulo alude a una obra distinta y sobre la cual versará el argumento discursivo, la autoficción es el elemento unificador de ellas, pues desde su condición de narradora-curadora de productos de artes visuales, Valdés transforma su novela en una exhibición, en una exposición que instruye al lector sobre el conjunto de obras que apreciará. El guion museal -entonces- se funde con la novela de manera que las intenciones de uno son las intenciones del otro. Nieto Ruiz (2014) recuerda y precisa los límites de la actividad curatorial cuando señala:

La curaduría tradicional tiene por objetivo, pues, ser una estructura de mediación entre el artista y el público a través de un discurso que implique y refleje el conocimiento tanto del artista como de la colección, la selección de ésta y el ordenamiento que mejor muestre al público la tesis propuesta, sin dejar de lado los objetivos y la imagen del lugar en el que se exhibe. Una buena analogía es ver a la curaduría como una guía en el campo del arte que traza senderos para la interpretación de las obras, los movimientos y/o los artistas (p. 19).

En su mayoría, cuando Valdés hace referencia a una obra de las expuestas en las salas, proporciona algunos antecedentes o datos importantes del artista, de la época y de los personajes representados para ubicar al lector en el contexto y convidarlo a ser partícipe de este. En la novela se lee:

Con La balsa de la Medusa, Théodore Géricault inauguró el primer reportaje periodístico apoyado en la imagen. La tragedia de la balsa de la Medusa constituyó un hecho real: en 1819, el pintor impuso un realismo superior al magisterio de David oponiéndose en estilo al neoclasicismo. El duque de Orléans se convirtió en el principal comprador de toda su obra a partir de 1814 , pero este cuadro fue posteriormente adquirido por el Estado (p. 71).

El tenor especializado que se reconoce en este pasaje, que se repite prácticamente en todas las obras escogidas para construir el guion (la novela), sustenta la idea de que la novela se construye a partir de la curaduría del narrador. Por supuesto, en el origen mismo de la actividad curatorial se encuentran los criterios de interés que van guiando la conformación o selección de las obras. Se cree que en la novela de Valdés la práctica curatorial se encuentra asociada con el gusto estético y los intereses personales de la narradora, quien ha declarado en entrevistas públicas que sus visitas constantes al Museo del Louvre sucedieron cuando atravesaba una época de crisis, de falta de motivación e inspiración. Desde esta perspectiva, es posible asumir que el museo se transformó en una instancia de salud (Deleuze, 1996) para la novelista y en consecuencia, los artistas seleccionados se convirtieron en sus psicoterapeutas, ratificando el nivel de incidencia que posee la obra de arte sobre el estado anímico de los seres humanos. "La écfrasis como una práctica cultural Ileva aparejada el interrogante sobre su 
función concreta en cuanto práctica" (Gabrieloni, 2008, p. 104); de manera que, en este discurso -por lo ya planteado- puede asumirse que la écfrasis adquiere también una dimensión psicológica.

La colección de obras escogidas por la novelista reúne los principios de una exposición colectiva, en la cual converge una diversidad de autores, géneros y estilos de representación. Sin embargo, en una mirada panorámica, el conjunto de obras se adscribe a la corriente figurativa de las artes visuales. No obstante, pese a esta pluralidad, existen elementos que demuestran el privilegio que le da la narradoracuradora a las obras que asumen la representación de la figura humana como leitmotiv. En términos generales, es posible plantear que son dos las líneas temáticas principales sobre las cuales se proyecta esta colección: los retratos y las escenas mitológicas, donde en su mayoría se percibe la figura humana semidesnuda o desnuda; las obras de carácter histórico, que establecen un vínculo más directo, desde esta perspectiva de lectura, con la problemática también histórica de la migración cubana y el exilio.

La primera obra referida, con la cual se da inicio al guion, es La Gioconda o La Mona Lisa; gesto muy suspicaz de Valdés, ya que esta pintura es uno de los principales atractivos no solo del Louvre, sino de la historia del arte universal. Consciente de ello, escribe: "es un retrato demasiado visto, pero no hay persona que no desee volverlo a ver; es una imagen que crea adicción" (p. 21). Adicción que se debe a las polémicas que ha generado por años en el mundo de las artes por su exquisita factura, así como también por su enigmática sonrisa e incluso por la ambigüedad de género, llegando a considerarse la obra más famosa del mundo que consagró para siempre la celebridad de su autor. La narradora-curadora es enfática en su juicio respecto del cuadro cuando apunta: "La Gioconda es la obra perfecta, el nec plus ultra del retrato del Renacimiento. La ilusión trasciende la tela, la belleza supera al óleo para volverse más espiritual que carnal" (p. 22). Con esta obra paradigmática en la Historia del Arte instaura un primer elemento a desplegar a través de su práctica narrativa: el tema de la reivindicación y la ambigüedad de género. Este no es casual, pues constituye un punto de reflexión en casi toda la obra valdesiana. La mujer, a través de las imágenes, es instaurada en este discurso novelar para aliviarla del ultraje a que ha sido sometida a través de la historia, debido a los dogmas de cosificación y discriminación instituidos por la cultura patriarcal de la que ha sido víctima. En el relato se nota la postura feminista de Valdés desde disímiles perspectivas, por ejemplo: los juegos e impulsos sexuales, el sexo por mero placer, que deriva en escenas lésbicas y la maternidad como marca social identificativa de la fémina. Al respecto, Butler (2002), propone y analiza el tema del cuerpo asociado con la maternidad y posteriormente, Guerra (2006) aborda la idea del cuerpo embarazado como lo que carece de lenguaje propio.

De ese don natural que es la maternidad y sin embargo posee significados esencialistas para las sociedades falogocéntristas, Valdés habla en el segundo capítulo, a partir de la écfrasis que establece con la pintura Alegoría sobre la instalación del Museo en la Galería Grande del Louvre:

-Mamá, eres una danaide -afirma el tercer hermano.

- ¡No, no y no! ¡Es una odalisca! -grita enrabietado el cuarto hijo.

-No discutan, sólo soy vuestra madre. Sólo eso, cuido de ustedes. Trabajo, y me pongo a escribir de vez en cuando.

Una nube entra por la ventana, atraviesa el cristal, desciende a nuestra altura. Mis hijos se montan en ella, yo detrás. Nos acostamos abrazados encima de una mullida y esponjosa nube. ¡No puedo creerlo! (p. 31).

El énfasis expresivo demuestra una de las tantas formas en que es tratado el cuerpo femenino, en lo referente a la función biológica de dar vida y las funciones sociales que le competen. Por ende, este discurso no se limita a los cánones de la narrativa falogocéntrica, sino que desde la visualidad revela una abierta crítica feminista.

En otro momento textual, Valdés - desde la interdisciplinariedad, apoyada en el recurso ecfrástico- cuestiona la práctica de ver y asumir el cuerpo 
constituido de la mujer como un signo cultural. Para ello centra su mirada en la estética del cuerpo de la Odalisca morena y con un lenguaje coloquial resalta la desnudez y la postura de este: "la hormiga ha caído encima de una nalga rosada de la muchacha que descansa encima de una cama desordenada, con su fabuloso culo al aire y las piernas entreabier-

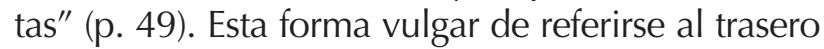
del personaje pictórico encierra un tono denunciatorio y cuestionador a la manera en que nombran a este componente corporal que, además, lo tienen codificado como objeto de placer los denominados sujetos masculinos.

El cuerpo es inscripto en este texto, desde su desnudez hasta la sexualidad a la que se expone, haciendo de la escritura una abierta reflexión que va más allá de los tabúes. Al respecto, Butler (2002), plantea lo siguiente: "El cuerpo implica mortalidad, vulnerabilidad, agencia: la piel y la carne nos exponen a la mirada de los otros pero también al contacto y a la violencia. El cuerpo también puede ser la agencia y el instrumento de todo esto, o el lugar donde 'el hacer' $y$ 'el ser hecho' se tornan equívocos”' (p. 40).

En su sexto capítulo, son dos obras del pintor francés Jean Honoré Fragonard ("El pestillo" y "El cerrojo y la camisa quitada"), las que se convierten en el foco de atención de Valdés, para "contaminar" su escritura y así desacralizar el estigma de la sociedad patriarcal que considera a la mujer como un objeto de placer.

Él le ruega a ella que le entregue su virginidad, ella finge que jamás se la dará, negada por los convencionalismos, sus padres, la familia. Todo ese tonteo para acabar con las piernas abiertas dentro de media hora, como mucho, iqué digo!, antes de quince minutos ya se ha levantado el vestido. Él es quien se quita la camisa un poco tarde (...).

La chica detrás de mí me besa la nuca, y su lengua discurre en mi oreja. Todo eso es absurdo, pero me gusta, me da un placer vertiginoso, que sube desde mis pantorrillas hacia mi garganta, y se me llena de burbujas la boca. Permanezco, sin embargo, in- móvil. Temerosa de hacer algún ruido y de romper el encantamiento (p. 53).

La reflexión paralela que realiza desde las relaciones sexuales y amorosas no solo entre dos, sino desde una mentalidad desinhibida y transgresora, compuesta por tres, se constituye como un mecanismo más para denunciar explícitamente la azarosa historia de objeto que ha vivido la mujer durante siglos. Para sustentar este planteamiento es meritorio señalar la idea expuesta por Aiello (2013):

En su discurso narrativo las reflexiones de la voz narrativa y de sus personajes sobre el deseo erótico de la mujer reconoce el vínculo intrínseco entre la sexualidad y el sentido de identidad tan importante para la mujer, en oposición a lo que históricamente el cuerpo femenino se ha reprimido y al doble modelo de moralidad que ha estado vigente y que aún prevalece en muchas de nuestras culturas (p. 9).

Es así como se puede aseverar que esta novela, a pesar de su manera compleja de escritura -concebida desde dos planos discursivos distintos interconectados- tan distinta al tono más explícito de la reflexión de género propuesta en sus otros textos, de igual modo tiene gran significación como discurso feminista, pues al realizar este gesto, la novelista no solo deja inscrito en la representación literaria la voz y el ser silenciado de la mujer, sino que a su vez está escapando a la situación de víctima, ya que es su obra el medio por el cual busca romper con la verticalidad del poder.

El segundo punto temático que unifica conceptualmente varios cuadros de la colección curatoriados por la novelista es el vinculado con sucesos históricos universales, que -sin embargo- desde esta perspectiva dan cuenta de la realidad socio-política cubana. Esta iconicidad se complementa con alusiones en la diégesis de la novela, que son muestras tácitas de la nostalgia que siente la narradora por su madre tierra y lo difícil que se le hace prescindir completamente de esos rasgos melancólicos.

En el texto existe una intención por textualizar desde la ficción, tomando como referente obras de arte, una realidad social -la cubana-, pues la escritora 
ha sufrido las consecuencias de la rebeldía frente al poder hegemónico castrista que la ha perseguido y condenado, al igual que a otros tantos cubanos en diáspora forzada. En este contexto, Valdés no pierde la ocasión para arremeter contra el discurso social y político instaurado hace más de cincuenta años en la isla. La novelista en su sitio web (zoevaldes. org) realiza una crítica fuerte al sistema de gobierno cubano y desde aquí mantiene su posición de animadora permanente de la posibilidad de cambio radical.

Entre las obras más significativas dentro de la curaduría construida, que pone en el tapiz el tema de la libertad anhelada por todo un pueblo, se encuentra La Libertad guiando al pueblo, que presenta un tema netamente histórico, en tanto muestra un suceso verídico para la historia de Francia que estuvo marcado por el deseo de emancipación y autonomía. Sin dudas esa carga semántica del cuadro y los calificativos asociados con ella se corresponden y son contextualizables con los anhelos de la sociedad cubana marginada, en la que predominan las restricciones, la represión y la censura, entre otros. No es azaroso que en la escritura enfatice en la palabra "libertad" planteando: "La libertad guía, armada de una bayoneta, e insta a que los hombres, las mujeres y los niños la sigan" (p. 16). La novelista, como colofón para este discurso eminentemente denunciatorio, dice: "La obra posee un movimiento cinematográfico piramidal. Es una pirámide de cuerpos hambrientos de libertad" (p. 16). Con esta metáfora final resume el principal nudo temático de la obra visual y exalta el sentimiento de dos territorios que, en distintos momentos históricos y circunstancias desiguales, se pueden emparentar, pues el móvil de lucha de sus connacionales es el mismo: la libertad que -por demás- es un derecho inalienable de todo ser humano.

Otro exponente que aporta iconicidad al relato es "La balsa de la Medusa", obra referencial sobre un suceso real, cuyos elementos composicionales posibilitan establecer un intertexto con la realidad sociopolítica cubana, específicamente en lo referente a las migraciones ilegales y casi masivas que se han estado sucediendo por muchos años desde Cuba hacia Estados Unidos, siendo ya casi un cliché respecto de la diáspora cubana. La narradora, cons- ciente de esto, se apoya en la écfrasis para presentar una metáfora épica de esta realidad.

Parada ante la inmensa obra de Géricault no puedo evitar la perplejidad, una y otra vez, la desesperación de esas personas luchando por la vida, en medio de un mar revuelto, me es sumamente familiar. Los cuerpos apilados, algunos a punto de caer al agua, otros ya muertos, los cuerpos descolgados hacia lo profundo del océano, otras figuras aún con los brazos apuntando a un horizonte imaginado, soñado quizás (p. 72).

Con este fragmento es importante destacar que, desde la interconexión entre las artes (visuales y literarias), Valdés describe esta dimensión histórica que es el denominado sueño americano o en inglés, the American dream; sueño que ha movilizado y costado la vida a miles de cubanos, los cuales en balsas abandonan la isla -así como lo refleja esta pintura con la cual se asocia en la trama novelar-y emprenden esta travesía extremadamente peligrosa, persiguiendo la libertad e igualdad de oportunidades. Por tales motivos, este discurso narrativo, sin perder la esencia ficcional, se torna revelador de una perspectiva sociopolítica que afecta al pueblo cubano, condenado al silencio y la doble moral. La autora no puede desligarse del compromiso social con su pueblo natal, con sus paisanos. Por eso, desde la escritura, desacraliza un discurso político oficial, en aras de reivindicar una realidad que ha sido manipulada por más de cincuenta años. La apuesta al todo o nada, la búsqueda de apenas una posibilidad, de una esperanza mínima de salvación induce a los cubanos a desafiar la fuerza de la naturaleza, los miedos físicos, psicológicos y simbólicos, elementos que atribuyen un carácter heroico y épico a estas travesías.

Como se ha ido demostrando, la representación según como la propone esta novela- "es un proceso por medio del cual el lenguaje construye y vehicula significados con distintos grados de referencialidad y de iconicidad" (Pimentel, 2012, p. 314). La novelista, víctima también de esa realidad cubana convulsa que critica fervientemente, conforma desde el exilio un universo narrativo determinado 
por lo ficcional, pero en el cual plasma referencias plásticas universales muy explícitas vinculadas con su rechazo a ese gobierno dictatorial (como ella lo denomina), ratificando con su técnica narrativa que "toda representación verbal contiene una serie de indicios de aquello a lo que puede relacionarse, y que constituye los elementos tanto de su contextualización como de su recontextualización" (Pimentel, 2012 , p. 317). Pero no son solo los elementos expuestos los que evidencian que la novelista no logra despojarse de un pasado que marcó huellas indelebles en su vida. Hacia el fin de la novela, en el último capítulo, concluye no solo el relato, sino que sintetiza de un modo ingenioso y sorprendente su vida de añoranzas. Su imaginación superpone dos realidades (La Habana y París). "Iba a cruzar la calle Línea hacia la otra esquina de $M$, en el Vedado, llevaba a mi hija de la mano. Entonces mis ojos parpadeaban, mi visión cambiaba, y detrás de un conjunto de árboles divisaba el Arco de Triunfo de París" (p. 172). Estas líneas ratifican que cuando la persona por circunstancias diversas ha tenido que abandonar sus orígenes y asimilar un proceso de aculturación -pese a vivir en un presente inmediato, totalmente distinto a lo que fue su vida pretérita- le resulta imposible desdeñar ese cúmulo de recuerdos y en este caso específico, la escritura es el medio idóneo que posibilita a la narradora yuxtaponer sus sentimientos, mantener los recuerdos, su memoria, como cuadros de una exposición, en un museo de palabras.

\section{LA ÉCFRASIS METALÉPTICA: RECURSO DE CONTAMINACIÓN INTERARTÍSTICA}

La dinamización originada en esta escritura por el proceso ecfrástico es impresionante. Las transgresiones entre la ficción y la realidad ofrecen un "incremento icónico" (Pimentel, 2012, p. 312) que permite ampliar el espectro de significación y posibilidades de lecturas al texto, es decir, "dotando de vida al relato". Esta idea fue sustentada por los autores progymnasmata (Teón, Aftonio, Hermógenes y Nicolao), quienes señalaban que el rasgo esencial de la écfrasis era dotar de vida al relato, acercándolo al lector (recuperado de Lozano-Renieblas, 2005).

Por su parte, Cid Hidalgo apunta (2017b) que Una novelista en el Museo del Louvre de Zoé Valdés "rompe con la dimensión estática del museo que congela, santifica y colecciona obras para, en un trabajo delicado y violento a la vez, otorgarles movimiento y vida" (p. 58). Desde esta perspectiva, en el último episodio referido, se lee:
Alberto me pasó el brazo encima de los hombros. Ya no era el pintor, tal como lo habíamos visto salir de su autorretrato, aho- ra era un joven judío, se llamaba Ilam, y aunque su cara era la misma que la de Du- rero ya no estaba vestido igual, ni llevaba el cabello largo (p. 173).

Con ello es notorio que la écfrasis metaléptica, además de "dar vida al relato", es el recurso que moviliza la narración, pues propicia que se superponga la identidad del pintor Alberto Durero con la de Ilam, el primer amor de la novelista, con lo cual se funden los límites de los distintos planos narrativos. La ficción dentro de la ficción pierde sus atributos, dando paso al despliegue de un lugar en que no existen privilegios ni estatus canónicos o al menos donde los estatus son reversibles: las visitas del museo asumen los lugares de los personajes que han salido de su "cárcel de paspartú" (Cid, 2017b, p. 58).

Zoé Valdés convida al lector a entrar en un mundo fantástico de penumbras y claroscuros en el cual los personajes de las obras del Museo del Louvre adquieren vida, se pasan de un soporte a otro e interactúan con la novelista que vive en el interior del museo parisino.

He percibido cómo, no solo durante la noche, intercambian sus puestos, salen los personajes a caminar o a bailar en las galerías centrales, conversan entre ellos, sin importarles estilos o épocas; por cierto, y esto es lo novedoso, en múltiples ocasiones, incluso de día y con las salas abarrotadas de visitantes, los personajes de los cuadros han abandonado al instante sus puestos (desde luego han sabido elegir a sus sustitutos, que han sido los propios asiduos al museo o visitantes extranjeros) (p. 17).

La narradora realiza un despliegue gozoso, haciendo que los personajes de las obras abandonen 
-inusitadamente- las posiciones que les fueron atribuidas por sus artistas ejecutores y que están delimitadas por el marco. Además, combina el sentido eminentemente crítico con el carácter lúdico, con la alegría que la caracteriza a ella y a los habitantes de su tierra natal caribeña, para de algún modo tergiversar la idea del museo como un espacio sacralizado y de culto a las obras de arte inmovilizadas.

El museo dinámico al que se refería Alfonso Reyes se instala a través de la experiencia de la novelista -quien selecciona el material de archivo (los enunciados según Foucault)que transita por aquel museo fantasmal que adviene por momentos museo-circo o museo-zoológico debido al carácter que van asumiendo los cuadros y sus relatos, los archivos y sus pruebas, la memoria y su perdurabilidad (Cid, 2017b, p. 58).

Valdés no descuida este sentido lúdico a lo largo de toda la obra. Desde su escritura defiende el entusiasmo y la jovialidad de los cubanos, haciéndolo notar en varios fragmentos, como cuando enuncia la aparición de la cantante Madonna, la cual durante su estadía en el museo es confundida con Esther, la protagonista de la obra pictórica que lleva por título "El baño de Esther". "La Ambición Rubia [una manera de nombrar a la cantante Madonna], mientras entona una de sus más populares canciones, repara en Desdémona, le sonríe, guiña pícara un ojo, la invita a subir al cuadro que ella ha convertido en escenario" (p. 100). Aquí, como en casi toda la novela, se rebasan los límites del paspartú debido a la mezcla confusa o extraña entre los personajes 'reales' y los 'pictóricos'.

Estos elementos revelan que el impulso narrativo de Valdés transgrede los márgenes de los objetos plásticos citados, porque los personajes de las obras salen de sus límites y se insertan en ese otro mundo ficcional del que aparentemente ellos eran la ficción. Cuando la novelista en el capítulo "Reflejo de luna en el ojo de una odalisca" alude a los cuadros de "La gran odalisca" y "El sueño de Endimión", de Ingres y de Girodet respectivamente, desde su escritura propicia el intercambio y el coqueteo de los personajes de ambas pinturas, extrayendo a Endimión del marco que delimita la obra que él prota- goniza, para trasladarse hacia donde está situada la Odalisca y declararle su amor.

Cupido posa sus labios en la frente de Endimión, enseguida moja sus labios con un racimo de fresas salvajes que gotean rocío. Endimión se despereza, desciende del marco de su cuadro, y atraviesa como Dios lo trajo al mundo los salones del museo (...) El hombre se sitúa frente a la Odalisca; aún resplandece en su costado el rayo de luna. Tiende una mano hacia la mujer. - Te amo, Odalisca - le declara su amor (p. 69).

La desestabilización de la relación realidad-ficción y de paso del mundo novelesco que el lector había "interpretado como realidad se 'desrealiza' para convertirse en ficción con respecto a una realidad que antes se había leído como ficción" (Pimentel, 2012, p. 345). Estos personajes, al igual que sucede con otras escenas plasmadas a lo largo de la novela, desplazan las fronteras de su mundo pictórico y se instalan en otro plano de realidad: el de la diégesis circundante.

La representación verbal de obras de artes visuales es asumida por Valdés como un proceso en que el lenguaje se comporta como "una estructura de mediación" (Pimentel, 2012, p. 314). Desde este enfoque de lectura, el capítulo "La orgía suicida de Sardanápalo" es un ejemplo significativo que, más allá de la alusión a la pintura "La muerte de Sardanápalo", inserta en la narración datos que se vinculan con la historia de su origen. Esto justifica la aparición repentina del escritor Lord Byron en el museo, colmado de orgullo por ser el inspirador de Delacroix. La narradora establece diálogo con Byron y de pronto:

El poeta me toma bruscamente por los brazos, de la misma manera en que uno de los guardias al pie del lecho del rey toma a una de las amantes, y como a ella me obliga a arrodillarme, de espaldas a él. Tironea de mi ropa, me desviste a la fuerza. Y completamente desnuda me lanza al interior de la obra. Caigo en la misma posición que Myrrha, la he reemplazado; sólo me resta levantar la mirada para comprobar que Lord 
Byron se halla recostado, asumiendo la posición de Sardanápalo (p. 80).

En el desborde narrativo, refiere la novelista que han pasado varios días y "sorpresivamente, entre el numeroso público que ha pasado a visitar esta obra, avizora el rostro fresco y hermoso de una señorita" (p. 80), quien confiesa a una amiga que se ha enamorado del rey de Nínive (Sardanápalo). "¿Cómo puedes decir que amas a un personaje de un cuadro? ¿Estás loca?" (p. 81). Lo planteado hasta el momento va dejando entrever que en el propio acto de escritura, la novelista no solo selecciona, sino resignifica el objeto que representa a partir de la écfrasis metaléptica como subgénero literario que posibilita la contaminación interartística. La escena continúa:

Aprovecho y le cedo a la joven el puesto de Myrrha. Sucedió muy fácil, bastó que el espíritu inflamado de Sardanápalo se lo pidiera a Lord Byron, con tal vehemencia, que me veo expulsada del cuadro y en mi lugar a la recién llegada (p. 81).

La écfrasis metaléptica, entonces, configura una escritura en la cual los personajes de las obras de arte superan, quebrantan y vulneran la frontera del contexto que los define, a la vez que los visitantes al museo se sumergen en ese mundo iconológico que veían como ficción. Ello provoca que el montaje de la ficción asuma un rol clave en el derrumbe de los convencionalismos de ambas ficciones entrelazadas: lo pictórico y lo narrativo.

En otro momento, específicamente en el capítulo "Las sombras del maestro y su discípulo", la écfrasis desarrollada produce una simbiosis narrativa que además aumenta su iconicidad. El relato plasma:

Entre esa marea de visitantes que no se detiene jamás, creo ver a La musa de Virgilio, también Ilamada La lectora con guirnalda de flores (1845) pintada por Jean-Baptiste Corot y fugada de su cuadro. Le digo al menos cierre su vestido, porque eso de que en el cuadro aparezca con el corpiño afuera está bien, porque ya no estamos en el cuadro (p. 89).
Una vez que la autora entrega esta serie de datos acerca de la obra pictórica con la cual trabaja, convoca al lector-receptor a establecer vínculos y alianzas, lo incita a buscar el referente visual. Esta relación que se establece entre ambas representaciones (la literaria y la visual) es de intermedialidad, ya que la imagen evocada se convierte en iconotexto que -al entrar en relaciones significantes con el texto verbal- imposibilita que ambas materializaciones puedan separarse, lo que en consecuencia produce un incremento icónico. En este ejemplo, la musa se escapa de la obra pictórica que protagoniza y se incorpora a la oleada de visitantes, cual si fuese una más del público, distorsionando -de esta maneralas posiciones habituales en las cuales se inscribe.

La écfrasis metaléptica es empleada como recurso literario mediador que origina y confunde el estatuto diegético de las figuras de las obras de artes visuales y de los personajes, haciendo que el lector vacile sobre el mundo que lo circunda, en el cual participa. Al recrear el escape de las figuras que protagonizan las obras de artes visuales de sus marcos delimitantes, es decir, cuando abandonan el paspartú que las guarda y preserva como bienes artísticos, Valdés establece una metáfora irónica con la idea de la huida y la búsqueda de la libertad plena del pueblo cubano. Los personajes ficcionales encarnan el deseo de todo un pueblo. Ellos -así como los cubanos reales- se empeñan en salir de la cárcel que enmarca su existencia física y los priva de la libertad plena. Los personajes se escapan de la cárcel del paspartú, así como los cubanos se van de su isla querida.

\section{CONCLUSIONES}

Al cierre de la presente investigación es imprescindible señalar que este análisis es el primero que se efectúa a Una novelista en el Museo del Louvre desde un enfoque académico que privilegia el desarrollo y materialización desde la interzona literaria y plástica. Su ejecución representó un gran desafío y se constituyó como una propuesta crítica de acercamiento intermedial al fenómeno descriptivo de las obras de artes plásticas realizado a partir del recurso estilístico de la écfrasis. 
A la luz de estas líneas de acceso a la novela, se constataron las peculiaridades del texto estudiado respecto de las otras obras de la autora cubana. El principio de la intertextualidad, mediado por la écfrasis, la alusión en el título al trabajo del argentino Manuel Mujica Láinez, la referencia directa a escuelas artísticas, temáticas y a vocabulario "técni$\mathrm{Co}^{\prime \prime}$ del mundo de las artes plásticas, dotan al texto de un espesor que viene a distanciar la novela de las otras producciones de la autora, a la vez que viene a sostener la competencia de la escritora en las zonas en que se mueve, desde donde da por sentado la necesidad del contagio interartístico. Por estas razones es posible creer que la noción curatorial fue clave para comprender el trabajo de selección y montaje de los distintos estímulos visuales que se fueron incorporando en el flujo de la novela. La narradora deviene, entonces, curadora de artes visuales y por lo tanto, creadora de un espacio de representación literaria que se va constituyendo en una especie de guion museográfico. El texto seduce e instruye al lector no solo en el nivel alegórico (el problema de "lo cubano"), sino también en el trabajo de exégesis plástica de las distintas obras. Con ello logra atribuirle al lector el rol de receptor "creativo", debido a que ambos comparten la focalización propuesta por la narradora en que la novela pareciera transformarse en la curaduría de una gran exposición.

La presencia de la écfrasis metaléptica, entendida como recurso retórico e intermedial, determina y configura la escritura, dotando de cierto carácter lúdico a la ficción plástica esbozada, a la vez que posibilita ampliar el rango de la exégesis. Por lo pronto posibilitó dinamizar el relato y el espacio museal tradicionalmente pensado desde la inmovilidad. Los personajes de las obras de arte se desplazan de sus posiciones ficcionales y se insertan en el mundo real presentado por la novela, intercambiando puestos con los personajes de la supuesta realidad e incluso con la propia novelista. Es decir, se transgrede el orden habitual y natural de ambos espacios y también, al narrar obras de artes plásticas o visuales significativas para la Historia del Arte Universal, incentiva al lector a activar sus redes de referencia y proyectar los conocimientos culturales que posee en un proceso de lectura dinámico. La relación intertextual o intermedial establecida entre la representación literaria y la visual, entonces, es de carácter contributivo, porque las imágenes que se evocan mediante la escritura se transforman en iconotextos que incrementan el valor icónico del discurso.

Un sello distintivo de la escritura de Valdés es su condición exiliar. Es en este contexto que la novela proyecta su posición frente al fenómeno de la diáspora y el castrismo con un fuerte sentido crítico, todo ello textualizado esencialmente cuando aborda sus preocupaciones referentes al género (la maternidad y el cuerpo desnudo de la mujer como objeto de placer sexual), así como la situación socioeconómica y política (carencias económicas y falta de libertad) que condiciona las migraciones masivas que tienen lugar en el contexto cubano. Esta modalidad adoptada convierte su discurso en un mecanismo a través del cual busca subvertir el poder.

La construcción del guion museográfico, en que deviene la novela, se organiza a partir de una selección interesada de los archivos que son instrumentales al interés último de la composición; es decir, va construyendo una discursividad crítica que alcanza planos superiores a los meramente estéticos. La crítica al sistema impuesto por Fidel Castro y la revolución cubana, la falta de garantías individuales, la represión permanente, la falta de libertad, la imagen de la mujer, etcétera, parecieran ser los temas hilvanados en ese guion museográfico que viene a debilitar al máximo los límites disciplinarios tradicionales asociados con el género novela.

\section{REFERENCIAS BIBLIOGRÁFICAS}

Agudelo Rendón, P.A. (2012). Entre realidad y ficción. La écfrasis literaria en "El engañoso cuadro" de Pedro Gómez Valderrama. Recuperado de http://publicaciones.eafit.edu.co/index.php/ co-herencia/article/viewFile/1764/1761

Aiello, A.J. (2013). El discurso narrativo de Zoé Valdés: Una escritura metaficcional. Recuperado de http://www.academia.edu/2759140/ El_discurso_narrativo_de_Zo\%C3\%A9_ Vald\%C3\%A9s_Una_escritura_metaficcional 
Alberdi, B. (2016). Escribir la imagen: la literatura a través de la écfrasis. Literatura y Lingüística, 33, 17-38.

Butler, J. (2002). Cuerpos que importan: sobre los límites materiales y discursivos del "sexo". Buenos Aires: Paidós.

Cid Hidalgo, J.D. (2016). Programa de asignatura "Imágenes textuales y textos pictoriales". [Código 4223119. Doctorado en Literatura Latinoamericana. Semestre 1-2016]. Concepción: Universidad de Concepción.

Cid Hidalgo, J.D. (2017a). Archivo y novela. Sobre la dimensión museal de la literatura latinoamericana. Literatura y Lingüística, 35, 159-178.

Cid Hidalgo, J.D. (2017b). Museo, novela, archivo. Aproximación a los museos de papel. Atenea, 515, 47-61.

Clüver, C. (1997). Ekphrasis reconsidered. On verbal representations of non-verbal Texts. U. B. Lagerroth, H. Lund and E. Hedling (edit) Interart poetics. Essays on the interrelations of the Arts and Media. Amsterdam: Rodopi.

Deleuze, G. (1996). Crítica y clínica. Barcelona: Editorial Anagrama.

Elsner, J.R. (2002). Introduction: The Genres of Ekphrasis. Ramus 31, 1-18.

Gabrieloni, A.L. (2008). Écfrasis. Eadem Utraque Europa. 4(6), 83-108.

Giraldo, E. (2015). Entrar en los cuadros. Écfrasis literaria y écfrasis crítica en los ensayos de Pedro Gómez Valderrama. Recuperado de http://publicaciones.eafit.edu.co/index.php/co-herencia/article/view/2979

Guerra, L. (2006). La mujer fragmentada: historias de un signo. Santiago de Chile: Cuarto Propio.

Heffernan, J. A. W. (1993). Museam of World. The Poetics of Ekphrasis from Homer to Ashbery. Chicago y Londres: The Universiy of Chicago Press.
Krieger, M. (1967). The Ekphrastic Principle and the Still Movement of Poetry; or Laoköon Revisited. The Play and Place of Criticism. Baltimore and London: The John Hopkins University Press.

Lozano-Renieblas, I. (2005). La écfrasis de los ejércitos o los límites de la enárgeia. Recuperado de http://revistas.um.es/monteagudo/article/ view/77221

Mitchell, W. J. T. (1994). Picture Theory: Essays on Verbal and Visual Representation. Chicago: University of Chicago Press.

Nieto Ruiz, C. (2014). Historia de una actitud ante la forma. De la curaduría tradicional a la curaduría artística. Recuperado de https://books.google.cl

Pimentel, L.A. (2003). Écfrasis y lecturas iconotextuales. Recuperado de http://www.lpimentel.filos.unam.mx/sites/default/files/poligrafias/4/13luz-aurora-pimentel.pdf

Pimentel, L.A. (2012). Écfrasis: el problema de la iconotextualidad y de la representación verbal. En Constelaciones I. Ensayos sobre Teoría narrativa y Literatura comparada. México: Bonilla Artigas Editores.

Ponce Cárdenas, J. (2014). Écfrasis: visión y escritura. Madrid: Editorial Fragua.

Riffaterre, M. (2000). La ilusión de écfrasis. Literatura y pintura. Antonio Monegal (Comp). Madrid: Arco/Libros.

Rodríguez, J.C. (2009). Zoé Valdés se transforma en "Una novelista en el Museo del Louvre", en homenaje a Manuel Mujica Láinez. Recuperado de http://ecodiario.eleconomista.es/ libros/noticias/1655802/10/09/Zoe-Valdes-setransforma-en-Una-novelista-en-el-Museo-delLouvre-en-homenaje-a-Mujica-Lainez.html\#. Kku828teero6UVU.

Schneck, E.P. (1999). Pictorial desires and textual anxieties: modes of ekphrastic discourse in nineteenth-century American culture. Word \& Image 15(1), 54-62. 
La écfrasis metaléptica: recurso representacional en Una novelista en el Museo del Louvre, de Zoé Valdés

Spitzer, L. (1962). The 'Ode on a Grecian Urn', or Content vs Metagrammar. En Anna Hatcher. (Ed.). Essays on English and American Literatute. Princeton: Princeton University Press.

Valdés, Z. (2009). Una novelista en el Museo del Louvre. Bogotá: Editorial Norma.

Wagner, P. (Ed.) (1996). Iconos - textos - iconotextos. Ensayos sobre écfrasis e intermedialidad. Berlín y Nueva York: Walter de Gruyter. 


\section{Los cuerpos cíborgs en cuatro cuentos de ciencia ficción costarricense}

Por Diana Martínez Alpízar', Universidad de Costa Rica

Recibido: 15 de enero, 2018.

Aceptado: 25 de marzo, 2018.

\section{Resumen}

Género poco estudiado en el ámbito nacional, la ciencia ficción en Costa Rica es aún un campo por explotar. Justamente, en este artículo se analizan cuatro cuentos de dicho género, publicados a inicios del siglo XXI: "Yo, la criatura" de José Ricardo Chaves; "Joyería mental" de Jessica Clark; "Lunas en vez de sombras" de Ericka Lippi y "El ejército de Onara" de Daniel Garro. Todos ellos tienen algo en común: la presencia de cuerpos cíborgs, objeto de interés en el presente análisis. Para este propósito, en un primer lugar se teoriza sucintamente sobre el género ciencia ficción; posteriormente, se explica el concepto de cuerpos cíborgs y su relación con lo poshumano, con base en los aportes teóricos de Donna Haraway, Rosi Braidotti, Katherine Hayles y Christian Hables Gray, entre otros. En cuanto al análisis literario del corpus, se examina la construcción y la descripción, a través de distintos recursos estilísticos, de los cuerpos de los personajes en los distintos textos. Se concluye que el corpus analizado, a partir de la lectura propuesta, muestra una serie de reflexiones sobre las tensiones, miedos, preocupaciones y posibilidades sobre el desarrollo científico y tecnológico asociado a las intervenciones y modificaciones en el cuerpo humano.

\section{Abstract \\ The Cyborg Bodies in four Costa Rican science fiction short histories}

Largely unexplored in the domestic field, the field of science fiction in Costa Rican Literature offers many opportunities for research. This article analyzes four Costa Rican science fiction short stories published in the early 21 st century: "Yo, la criatura" by José Ricardo Chaves, "Joyería mental" by Jessica Clark; "Lunas en vez de sombras" by Ericka Lippi, and "El ejército de Onara" by Daniel Garro. All of these works have something in common: the presence of cyborgs, the focus of this analysis. To this effect, firstly it offers a brief theorization about science fiction; hereinafter, the notion of cyborg and its relation with post-humanity are explained, based on authors Donna Haraway, Rosi Braidotti, Katherine Hayles, and Christian Hables Gray, among others. Regarding literary analysis, this article focuses on construction and description, through the stylistic resources of the bodies of the characters in the short stories, offering an individual interpretation of each one and closing with a comparison between the different propositions. It concludes that these short stories show different reflections, tensions, fears, concerns and possibilities on science and technology linked with the modification and intervention of the human body.

1 Bachiller en Filología Española y Máster en Literatura Latinoamericana, ambos títulos obtenidos en la Universidad de Costa Rica. Actualmente labora en esta misma institución, en la Escuela de Estudios Generales. Contacto: dimartinezalpizar@gmail.com.
Diana Martínez Alpízar. Los cuerpos cíborgs en cuatro cuentos de ciencia ficción costarricense. Revista Comunicación. Año 39, volumen 27, número 1, enero a junio, 2018. Instituto Tecnológico de Costa Rica. ISSN: 0379-3974 / e-ISSN1659-3820.
PALABRAS CLAVE:

Ciencia ficción, cuento, análisis literario, cibernética, literatura latinoamericana

\section{KEY WORDS:}

Science fiction, short stories, literary analysis, cybernetics, Latin American literature. 


\section{INTRODUCCIÓN}

Las tensiones y relaciones entre literatura, ciencia y desarrollo tecnológico no son ninguna novedad en el contexto latinoamericano. Basta recordar la aparición, en 1879, de la novela Horacio Kalibang o los autómatas, escrita por el argentino Eduardo Holmberg, texto que -según Brown (2010) - inaugura la ciencia ficción en la literatura hispanoamericana.

En el caso de la literatura nacional, según Molina (2010 y 2015), es posible rastrear los orígenes de la ciencia ficción en la literatura costarricense desde finales del siglo XIX e inicios del siglo XX con textos como el cuento "El número 13,013" (1908) de León Fernández Guardia o bien, las novelas El problema, del guatemalteco Máximo Soto Hall, pero publicada en Costa Rica en 1899 y La caída del águila (1920) de Carlos Gagini. No obstante, hay que dejar que el tiempo transcurra, pues es en la década de 1990 cuando el género toma fuerza para, según Pacheco Solórzano (2014), renovarse discursivamente con los autores que publican a inicios del siglo XXI, cuyos textos muestran "un salto cualitativo" (p. 65) en relación con producciones anteriores.

En contraste con este auge del género a finales del siglo XX e inicios del XXI, la academia costarricense se ha acercado tímidamente a su estudio. Si bien especialistas como Víquez Jiménez (2014), Soto Bogantes (2014), Ruiz Ulloa (2014), Cuvardic García (2014), Alfaro Vargas (2014) y el mismo Molina (2010 y 2015) se han dedicado a analizar diversos textos de este género, la labor de profundizar en su análisis en la literatura costarricense está en ciernes.

Justamente, este artículo se interesa por indagar en un tema particular de la ciencia ficción costarricense: aquellos cuerpos ficcionales que, a través de la intervención tecno-científica, difuminan o ponen entredicho los límites entre la naturaleza y la tecnología: ¿son máquinas o humanos, o quizá un "algo" diferente? Este "algo diferente" refiere precisamente a la presencia de cuerpos cíborgs en un corpus particular de cuentos escritos por los autores José Ricardo Chaves, Jessica Clarke, Ericka Lippi y Daniel Garro. La muestra seleccionada es representativa y no exhaustiva, claro está. Queda para futuros artículos ahondar en ello.
Con el propósito de analizar dichos cuerpos, el recorrido teórico-metodológico será el siguiente: en un primer lugar, se referirá brevemente a la noción de "ciencia ficción", con la intención no de agotar el tema -misión ya de por sí imposible- sino más bien con el propósito de establecer delimitaciones conceptuales inherentes al artículo. Posteriormente, se enriquece la discusión teórica con la aproximación al concepto cíborg y su relación con lo poshumano, con base en autores como Haraway (1984), Hayles (1999), Gray (1999, 2011), Sádaba (2009) y Braidotti (2015), entre otros.

\section{BREVE TEORIZACIÓN BÁSICA}

Uno de los primeros puntos de análisis yace en la definición del término "ciencia ficción", categoría en la cual se incluirían todos los cuentos del corpus seleccionado. La polémica sobre este concepto es amplia, por lo que para fines pragmáticos se recurre a dos autores cuya visión del género es compatible. En primer lugar, Eco (1998) se refiere a la ciencia ficción como un género en el que, a partir de las tendencias del mundo actual, extrapola otras que podrían desarrollarse en el futuro. Este carácter conjetural es tanto la esencia del género en sí como del quehacer científico: "En otros términos, la ciencia ficción es una narrativa de la hipótesis, de la conjetura o de la abducción y en ese sentido es juego científico por excelencia, dado que toda ciencia funciona mediante conjeturas, esto es abducciones" (Eco, 1998, p. 654).

Moreno (2010), por su parte-Gunn (2005) y Malmgren (1988)- explica que la ciencia ficción se caracteriza principalmente por "la inclusión de elementos no existentes en nuestra realidad inmediata, pero considerados "posibles" desde algún ámbito del conocimiento científico" (p. 106). Al igual que Eco, Moreno (2010) da especial valor a la proyección basada en elementos no sobrenaturales para caracterizar al género. Además y otra vez en coincidencia con Eco, Moreno entiende "conocimiento científico" en un sentido extenso; es decir, no lo reduce a las ciencias duras, sino que lo aplica también a otras áreas (sociología, lingüística, historia, etc). También es importante destacar otra aclaración de Moreno: poco importa que el "descubrimiento tecnológico" del cual se hable quede desfasado; pues, 
a través de un pacto de lectura con el texto, es en el conflicto entre el "descubrimiento tecnológico" y los personajes donde yace la relevancia del género.

Dentro del mismo género de ciencia ficción, hay temas recurrentes. Uno de ellos es la creación de cuerpos cíborgs. ¿De dónde proviene este término, popularizado en el ámbito académico por Donna Haraway en los 80? El origen de la palabra se remonta en realidad a los años 60 , en el contexto de la carrera espacial durante la Guerra Fría. Como explican Gray (1999) y Sádaba (2009), el término fue acuñado originalmente por Manfred Clynes y Nathan Kline, científicos en ese entonces de la NASA, quienes en un artículo argumentaban que los cuerpos humanos podrían ser modificados -a través de implantes y drogas- con el fin de que pudieran vivir en el espacio exterior sin necesidad de trajes espaciales. De esta forma, ellos propusieron la creación de cíborgs, palabra compuesta de la contracción de cybernetic organisms, cuya traducción sería "organismos cibernéticos".

A grandes rasgos, con el fin de aclarar el concepto del inicio, si bien hay distintas aproximaciones al cíborg, todas coinciden en que este se constituye a través de la mediación de la tecnología en un cuerpo biológico. Aunque la palabra correcta, como precisa Sádaba (2009), no es mediación, sino integración:

En general, entenderemos por cyborg la integración hombre-máquina en sus diferentes vertientes y versiones, un tipo especial de relación (individual y social) entre los sistemas naturales (biológicos, orgánicos) y los sistemas inorgánicos o técnicos (mecánicos, eléctricos, digitales, etc.) en la cual se diluyen las fronteras de los mismos (p. 35).

Propiamente en el ámbito académico y político, el cíborg será retomado y reconceptualizado como una categoría de análisis, al mismo tiempo que como una metáfora de las rápidas y constantes transformaciones tecnológicas y científicas. En este desarrollo, es necesario mencionar en un primer lugar a la feminista estadounidense Donna Haraway y su ya famoso Manifiesto cíborg. En él, Haraway (1984) entiende el cíborg como "un organismo ci- bernético, un híbrido de máquina y organismo, una criatura de realidad social y también de ficción" (p. 2). Este ser quimérico y utópico, invisible, pero ubicuo (de ahí su carácter mortal, apunta Haraway) confunde no solo los límites fundantes de las dicotomías natural-artificial, sino todas aquellas divisiones binarias del pensamiento occidental:

(...) entre la mente y el cuerpo, lo animal y lo humano, el organismo y la máquina, lo público y lo privado, la naturaleza y la cultura, los hombres y las mujeres, lo primitivo y lo civilizado están puestas ideológicamente entredicho (...) (Haraway, 1984, p. 18).

Como bien explica Sádaba (2009), Haraway ve en el cíborg la posibilidad de crear nuevas subjetividades, distantes tanto de las divisiones dicotómicas y jerarquizadas de la modernidad como del sujeto cartesiano, racional. Con propuestas muy vinculadas a la de Haraway, Katherine Hayles (1999) y Rosi Braidotti (2015) también se interesan por los cuerpos cíborgs, pero utilizan el término poshumano para referirse no tanto a un cuerpo modificado, sino a una etapa de la evolución humana, caracterizada por la imbricación entre los cuerpos biológicos y las máquinas, que además contempla una interacción con el entorno, todo parte de un mismo sistema. En lo poshumano, según Mejía (2005), al igual que con la propuesta cíborg de Haraway, se pone en jaque la idea del cuerpo humano propias del humanismo moderno.

Para entender esta idea de cuerpos poshumanos y por ende, cíborgs, se analiza brevemente las propuestas de Halyes (1999) y Braidotti (2015). Con coincidencias en diversos puntos, las dos rehúyen -por ejemplo- a acercamientos pesimistas y apocalípticos sobre la integración de los seres humanos con máquinas. Hayles (1999), por su parte, apunta a que este no es el fin de lo humano, sino más bien el acceso a nuevas configuraciones culturales de este, diferentes por completo al sujeto del humanismo liberal y su deseo de controlar y dominar, ya que el ser humano interactúa no solo con las máquinas, sino también con su entorno, todo parte de un sistema cognitivo común. Braidotti (2015) -por otro lado-advierte sobre las implicaciones biológicas de 
este proceso de comunión de carne y máquina, a la vez que apuesta a que sea un terreno fértil para pensar en identidades basadas en la transversalidad, es decir, que surjan a través del establecimiento de relaciones con los otros (cibernéticos u orgánicos), así como con el entorno:

Yo creo que el fin de la posición posthumana es reconsiderar la evolución de manera no determinista, y al mismo tiempo, posantropocéntrica. En oposición a las ideas clásicas, lineales y teleológicas de la evolución (Theilhard de Chardin, 1959), me complace evidenciar el proyecto colectivo de encontrar una más aproximada interpretación de la complejidad de factores que estructuran el sujeto posthumano: la nueva proximidad a los animales, a la dimensión planetaria y a los altos niveles de mediación tecnológica (Braidotti, 2015, p. 95).

Parte del movimiento poshumanista, pero con marcadas diferencias a los enfoques de Hayles y Braidotti, la propuesta del Ilamado transhumanista impulsada por Robert Peperell, Hans Moravec y Marvin Minsky, defiende -según Chavarría Alfaro (2015) - "la intervención de la naturaleza humana para llegar más allá de sus límites biológicos" ( $p$. 7). Es decir, este grupo de acaudalados científicos está a favor de realizar una "ciborización" del ser humano, mediante modificaciones genéticas, con el fin de llevarlo a un próximo nivel: incrementar las potencialidades del cuerpo, librarse del envejecimiento, de enfermedades e, incluso, de la muerte.

Obviamente, esta propuesta ha recibido críticas inclusive por parte de los mismos teóricos poshumanistas. Braidotti (2015), una de estas voces críticas, explica que el movimiento transhumanista es una muestra, pero con distinto nombre, de la arrogancia humana. El transhumanismo oculta -según esta autora- el deseo de transcendencia propio de un sujeto individualista y egoísta.

Sin embargo, a pesar de los sueños poshumanos, hay voces divergentes, entre ellas la del ya fallecido David Franklin Noble. Calificado por alguno de sus detractores como tecnófobo, crítico no solo del transhumanismo, sino de cómo se encamina el de- sarrollo tecnológico en la actualidad, Noble -historiador de profesión- es completamente escéptico de las promesas de felicidad, bienestar y progreso, tanto colectivo como individual, derivadas de la alianza entre ciencia y tecnología. Según Sádaba (2009), Noble advierte sobre una sociedad corta de miras, obsesionada con los avances en el campo tecnológico y dócil ante los cantos de sirenas en este campo, sin darse cuenta del peligro latente de una sociedad deshumanizada, en la que las máquinas se convierten en fetiches a idolatrar.

Como último punto controversial en torno al poshumanismo y por ende al cíborg, no podía ser obviado el cometario sagaz de Mejía (2005). Este advierte que gran parte de estas teorías poshumanas provienen de científicos e intelectuales de regiones hegemónicas, quienes proclaman el ocaso del cuerpo, en tanto "(...) los hombres y mujeres occidentalizados de países desfavorecidos apenas reivindican el derecho a comenzar a poseer sus propios cuerpos" (Mejía, 2005, p. 146).

Más allá de las divisiones de tecnófobos y tecnófilos, ¿qué tan lejos se está de los escenarios ya planteados? ¿Son propios de la ciencia ficción y de representaciones culturales ficcionales concretas o más bien pertenecen al día a día? Para Gray (2011), los cíborgs son una realidad muy actual no solo en el campo militar-su principal área de interés-, sino también en lo cotidiano. Es más, la transformación del ser humano a través de la tecnología no es para nada un proceso nuevo: el uso de la tecnología le ha permitido adaptarse, apropiarse del medio y por ende, sobrevivir a través del tiempo. Por lo tanto, se constituye en una forma de evolución artificial, más acelerada que la biológica. El cíborg es, por consiguiente, una escala más en esta evolución. Para Gray (2011), la pregunta a plantearse no es si los cuerpos humanos son cíborgs o no, sino más bien de qué tipo.

De hecho, el mismo Gray (en Córdoba Guardado, 2007) propone tres categorías de cíborgs, de acuerdo con el nivel de integración social humano-máquina:

(...). 1. Simple controllers interfaces informacionales que incluyen redes de 
ordenadores, comunicaciones humano ordenador, vacunas y manipulaciones de informacióngenética;2. Bio-tech integrators, ampliaciones mecánicas simples, como las prótesis médicas, vehículos o sistemas de armamento hombre-máquina; 3. Genetic cyborgs, conexiones hombre-máquina directas como los exoesqueletos militares de vanguardia, así como los planes de descargar conciencias humanas en ordenadores forman parte de esta última categoría (movimiento transhumanista) (p. 261).

Con base en la propuesta de Gray, Sádaba (2009) establece entonces tres tipos de cíborgs, según la integración de lo orgánico con lo inorgánico. El primer tipo consiste entonces en una integración endógena, en la que el ser humano muta con el fin de asimilarse a una máquina. El cuerpo orgánico se modifica (ya sea a través de prótesis, una mecanización, una electrificación) con el fin de potenciarlo. La carne anhela al cero.

En el segundo tipo de integración, en cambio, es la máquina la que más bien imita a lo orgánico. En estos casos, el ser humano -como si fuera un tipo de deidad- crea seres metálicos a su imagen y semejanza. "Nos recuerda, en este caso, al viejo tópico de la inteligencia artificial (IA), a la fabricación de robots pensantes y sensibles, de maquinaria cuasi humana, de réplicas perfectas, indistinguibles del original" (Sádaba, 2009, p. 39).

Finalmente, según Sádaba (2009), en el tercer tipo de cíborg, la costura que divide la carne de lo inorgánico se vuelve más fina, más difusa, incluso imperceptible, pues la fusión entre uno y lo otro surge desde su mismo origen: seres quiméricos, fruto de los desarrollos de la biotecnología y la tecnología, "fusión e hibridación desde la gestación" (p. 39). Se está - entonces- ante el mundo de la manipulación genética.

\section{EL CÍBORG EN CUATRO CUENTOS DE CIENCIA FICCIÓN COSTARRICENSE}

Sentada de manera concisa la discusión en torno a los cíborgs y sus implicaciones, en seguida se ana- liza la selección de textos escogidos, en los cuales es posible hallar su presencia. Antes, eso sí, algunas aclaraciones sobre el corpus escogido. Estos textos han sido todos escritos por distintos autores costarricenses y publicados en dos antologías de ciencia ficción de las primeras dos décadas del siglo XXI: Lunas en vez de sombras y otros relatos de ciencia ficción (2013) y Objeto no identificado y otros cuentos de ciencia ficción (2011).

En un juego intertextual basado en Frankenstein, el clásico de Mary Shelly, José Ricardo Chaves (2013) presenta su versión del cíborg en el texto "Yo, la criatura". A través de un narrador en primera persona, en este cuento se lee la historia de Victoria, cuyo cuerpo -conformado por la unión de seis cadáveres distintos, uno de mujer y el resto de varones- cobra vida gracias a los conocimientos científicos sobre la electricidad que posee el doctor Víctor Frankestein.

Victoria vive -pues- gracias a la simbiosis de componentes orgánicos y un sistema eléctrico. Por ser incombustible, a la que las llamas le producen solo "un cálido aliento sobre la piel" (Chaves et al., 2013, p. 8), Victoria se denomina a sí misma la hija eléctrica del fuego.

Sin embargo, el cuerpo de Victoria presenta otros rasgos todavía más interesantes que la acercan a la noción utópica de cíborg propuesta por Haraway (1984), ya que con su existencia transgrede diversas dicotomías del pensamiento moderno occidental. Para empezar, la genérica: hombre-mujer, masculino-femenino. Si bien su nombre, en clara a alusión al de su padre, es femenino, Victoria no coincide precisamente con ninguna de las clasificaciones genéricas, tampoco con el sujeto cartesiano estable y único. Su identidad es compleja, múltiple, escindida y abyecta, además de gobernada por el lado femenino: “(...) Estoy segura de no ser hombre, aunque dudo de ser mujer. Soy algo que antes no había existido. Los yoes masculinos coexisten conmigo pero yo arreo el rebaño... ¡ Lo que es la fuerza del útero (y del corazón)!..." (Chaves et al., 2013, p. 5).

De igual forma, la constitución y caracterización del personaje también pone en jaque la división entre cultura y naturaleza, lo civilizado y lo primitivo: a pesar de su apariencia monstruosa y animalizada, 
su piel amarillosa, su cuerpo deforme, sus labios negruzcos, su "fuerza y agilidad extraordinarias" (p. 6) y su capacidad de sobrevivir con poca comida, Victoria también posee un gran bagaje cultural (ha leído a Milton, Volney, Plutarco y Goethe). Además, tiene una sensibilidad particular para la música: toca la flauta y canta preciosamente. Amalgama, pues, cualidades notables relativas a la cultura y la naturaleza.

Este carácter híbrido y monstruoso pareciera condenar a Victoria a la soledad. Su creador, Víctor, se niega a engendrar descendencia con ella, a pesar de las constantes intimidaciones y amenazas de Victoria. Ella -ante esta actitud- mata uno a uno a todos los miembros de la familia de Víctor, en una especie de ley de Talión: soledad como castigo de la soledad engendrada.

No obstante, la criatura logra su cometido, ya que copula y concibe un hijo con Ernesto, el hermano de Víctor, cuando este se halla ebrio. La consecución de este embarazo resalta el carácter triunfante, victorioso, del personaje, quien no solo reescribe con su relato la historia oficial, sino que también se acepta y se afirma en su gozosa monstruosidad. De ahí que el título del relato sea un de acto proclamativo de la asunción de su identidad: "Yo, la criatura". Título que -por cierto- es a su vez un guiño intertextual a la colección de relatos Yo, robot del escritor y bioquímico Isacc Asimov.

Publicado también en el mismo cuentario que el texto de Chaves, en "Joyería mental", de Jessica Clark, se está ante la presencia de un cíborg de integración endógena, según la propuesta de Sádaba (2009). La tecnología, específicamente los neuroprogramas creados y comercializados por la doctora Abha, les permiten a sus usuarios acceder a distintas emociones o comportamientos: pánico, amor incondicional, la sensación de fumar opio. En esta lujosa tienda, cada cliente escoge qué emoción "colocarse", según los deseos o necesidades, tal y como si fueran uno de los bindis utilizados por Abha. En este texto de Clark, la irracionalidad de las emociones humanas se somete, con el fin de manipularlas al gusto de cada quien, a través del conocimiento biotecnológico.
Ahora bien, el texto de Clark apunta, desde la lectura de quien escribe, a una insuficiencia de dicho conocimiento: si bien esta tecnología permite modificar la estructura del cerebro y por ende, la producción de ciertas hormonas, su mera existencia no resuelve por completo las crisis existenciales del ser humano. Este fracaso se evidencia en el texto con la historia de Jake, hombre inteligente, con apariencia de "rebelde adinerado" e íntimo amigo de la doctora Abha.

Jake guarda un oscuro secreto en su pasado, no aclarado por completo en el texto: de alguna manera, el personaje estuvo involucrado en el asesinato de su amigo Joao. El peso de esta culpa provoca que Jake consuma constantemente alcohol, sustancia que lo hace sentir momentáneamente mejor (un placebo menos sofisticado que la joyería mental). Con la intención de ayudarlo, Abha crea los neuroprogramadores y lleva 4 años pensando en el ideal para Jake, con la idea de ofrecérselo como regalo. Donado por un astronauta, el original obsequio consiste en "la reacción de la mente al sonido del sol" (Chaves et al., 2013, p. 19).

A pesar de su originalidad, este maravilloso regalo no alivia la carga y la culpa de Jake. Paradójicamente, las palabras de consuelo de su amiga resultan ser más efectivas. Por eso ante la pregunta de si las pastillas lo ayudarán a olvidar lo sucedido, Abha le responde que no, pero le ofrece como consuelo las siguientes palabras: "—De por sí, Joao no era buena persona-murmuró ella" (p. 20). La reacción de su amigo evidencia el poder de estas: "Jake sonrió en la penumbra" (Chaves et al., 2013, p. 20).

Escrito en primera persona, en "Lunas en vez de sombras" (2013), de Ericka Lippi, la configuración del cíborg en este texto opera de una manera similar al previamente analizado de Clarke, ya que se está de nuevo ante un cíborg perteneciente a la segunda categoría según Grey. Esta vez el objeto que provoca la modificación de la parte biológica es una pastilla llamada "Psoria", medicamento que mejora la productividad de aquel que la consume:

Se trata de una oportunidad para que, tanto el hemisferio izquierdo como el derecho, logren un equilibrio. Si quiere un cambio y 
desempeñarse con excelencia en todos los aspectos de su vida, consuma Psoria. Maximizará sus niveles de energía. La energía negativa se convertirá en energía positiva. Sea mejor padre o madre de familia, mejor hijo o hija o mejor estudiante (Chaves et al., 2013, p. 49).

El "Psoria" se convierte en un medicamento idóneo para la sociedad descrita en el texto, obsesionada no solo por el rendimiento eficaz y eficiente de los cuerpos ("maximizar los niveles de energía", como se indica en la cita anterior), sino también por moldearlos según un estándar de belleza y salud, particularmente importantes en una sociedad agobiada por una epidemia de obesidad. Sue, la vOz narradora y personaje principal del texto, es parte de esta industria tecnológica: como nutricionista, ella trabajó en la compañía encargada de diseñar y fabricar "Psoria".

Sin embargo, a pesar de todas las ventajas que aparenta producir, "Psoria" presenta un serio efecto secundario: provoca grandes lagunas mentales en su consumidor, quien será incapaz de recordar momentos cercanos en su pasado. Sue -por ejemplo-no logra recordar qué hizo ni con quién ha estado durante las noches. Ella entra en un "trance de luna", de ahí la constante referencia en el texto a la canción de la violinista Lindsey Stirling que Ileva justamente el nombre de Moon Trance.

El tiempo, pues, pasa a ser uno de los principales puntos de reflexión del relato: ¿qué significa utilizar el tiempo eficientemente?, ¿cumplir a cabalidad con un horario de labores?, ¿vale la pena vivir sin poder recordar?, ¿qué es el ser humano sin su capacidad de memoria? No en vano, Sue piensa constantemente en La persistencia de la memoria, el famoso cuadro de Dalí, para simbolizar estas interrogantes:

Tengo la sensación de que la noche transcurrió en tres segundos. Los relojes blandos de Salvador Dalí vienen a mi mente. Me miro la mano. Algunas veces tengo la impresión de que mis manos se encuentran mojadas por el tiempo que se escurre en mis manos (Chaves et al., 2013, p. 46).
Como se observa, si bien la pastilla permite mejorar la capacidad de producción y concentración de quien la toma, para convertirse en un eficiente y productivo cíborg, este proceso no resuelve las eternas reflexiones sobre la inexorabilidad del tiempo y la fugacidad de la vida. En este sentido, al igual que en el texto anterior ("Joyería mental"), el proceso de convertirse en un cíborg no hace más sencillos los dilemas existenciales o éticos de los personajes.

De hecho, además de la reflexión del tiempo ya aludida, Sue también se enfrenta a un cuestionamiento respecto a su ética profesional, al descubrir que el anodino y cortante nuevo cliente es en realidad un sofisticado androide, creado como parte del nuevo proyecto secreto de su exjefe y amante Mike, hombre brillante, pero ambicioso y capaz de transgredir las reglas o engañar para hacer dinero:

Sabía que era un hombre sumamente capaz como químico y físico, con una facilidad excepcional para el mercadeo y una capacidad de convencimiento tan extraordinaria que rozaba la hipnosis. También conocía cómo había cedido a ciertas presiones por una ambición insana (Chaves et al., 2013, p. 48).

Al final del relato, Sue debe decidir qué hacer: colaborar con el proyecto de Mike, con todas sus implicaciones éticas y concretar su estabilidad económica o-por el contrario- cortar de raíz, alejarse tanto de Mike como de sus intenciones de crear androides, aunque esto implique un futuro económico incierto. La respuesta a esta incógnita queda abierta al cierre del texto.

Con un abordaje diferente a la figura del cíborg, en el último texto por analizar, "El ejército de Onara", de Daniel Garro, se narra la historia de la almirante Liz Benet, asignada junto con su ejército (la Compañía de $C$ de Impacto Terrestre) a Onara, con la finalidad inicial de destruir el laboratorio de Coli, un niño genio, "tal vez de ochos años en la medida terrestre" (p. 55), quien en sus experimentos creó seres híbridos, monstruos; en palabras de Benet: "mezclas y más mezclas horribles de personas y animales" (Castillo et al., 2011, p. 43). 
El laboratorio de Coli es destruido con todos y cada uno de sus experimentos, de sus hijos, como él los Ilama. Un año después, el científico se venga y destruye todo el ejército de Benet, excepto a ella, como un acto de retribución por haberle perdonado la vida en la destrucción de su laboratorio.

Como se observa, según la trama del texto, el cuestionamiento sobre los límites de la experimentación con humanos es clave para interpretarlo no solo por los experimentos realizados por Coli, sino también por la misma conformación del ejército liderado por Benet, compuesto por cíborgs militarizados:

(...) los soldados Genélite, de alto desempeño, altos, fornidos, un poco brutos, de brazos y piernas tan musculosos y arqueados que más bien lucían redondos, con cañones y armas en los antebrazos, un pesado casco electrónico, y los miembros y el torso cubiertos de prótesis de defensa y maximización física (...) (Castillo et al., 2011, p. 34).

Estas modificaciones les permiten a estos soldados tener más fuerza y resistencia física, pero también los convierte en seres grotescos y animalizados: antes del enfrentamiento, gruñen, escupen y se frotan los dientes como rottweilers. En este caso, la tecnología bélica potencia la parte biológica del cuerpo humano de los soldados, armas sofisticadas a la misma vez que seres degradados, irracionales, impulsivos y rabiosos. De hecho, estos rasgos terminan provocando la muerte de los Genélite; uno de ellos -Torre- se descontrola pues cree que van a ser atacados. En realidad, la paranoia del soldado se activa ante el juego de luces y sonidos que Coli les presenta a manera de trampa. Al creerse atacado, el soldado abre fuego indiscriminadamente, lo cual inicia una confusión entre el resto de sus compañeros, quienes se disparan entre sí y terminan matándose.

Esta monstruosidad de los cuerpos cíborgs de los soldados contrasta con la belleza de Benet: “(...) mujer imponente, alta, robusta y hermosa a sus cincuenta años, con un físico poderoso y esbelto que hacía preguntarse: ¿el uniforme la hace lucir bien, o tal vez ella hace lucir bien al uniforme?" (p. 40). Este personaje tampoco ha sufrido modificación alguna y encarna, en contraste con la mayor parte de sus subordinados, características como la misericordia, la compasión, incluso actúa en ocasiones de forma maternal. Para Coli, ella resulta un interesante contraste en comparación con la brutalidad de los soldados modificados genéticamente; de ahí que con curiosidad le diga: “¡Eres tan diferente!" (Castillo et al., 2011, p. 56).

El origen de estos soldados cíborgs es también otro de los puntos llamativos del texto. Según se supone por las palabras de Brolin -uno de los tantos Genélite- él se convirtió en un cíborg luego de ser herido brutalmente en la cabeza en un enfrentamiento militar: "-Mmmme hirieron en Arinax 3-dijo Brolin, con un aire de orgullo que logró colarse entre sus muecas de histeria -P-p-prácticamente....me volaron la cabeza, ipe-pero acá estoy!" (Castillo et al., 2011, p. 39).

Según la cita anterior, se deduce que se experimentó con soldados en condición crítica. ¿Quién decidió entonces que ellos serían intervenidos? ¿Son estos soldados producto también de "jueguitos" y experimentaciones genéticas similares a las de Coli? ¿Cuál es pues la diferencia entre un bando y otro? ¿Si Coli es un monstruo al experimentar y crear seres híbridos, pertenecientes al tercer tipo de integración, según Sádaba (2009), qué diferencia hay entonces entre el niño científico y aquellos que ordenaron la creación de los Genélite?

No deja también de ser llamativa la forma en que se resuelve el texto: al final, los únicos sobrevivientes son aquellos personajes humanos en su totalidad: Coli y Benet. Ambos vivos gracias a que, en algún momento de la trama, fueron objeto de la misericordia de otra persona.

A grandes rasgos, en este texto el cíborg no se vincula con la trascendencia del ser humano a un plano superior, sino con su degradación: en manos equivocadas, como indica Sádaba (2009) en un parafraseo de Goya, el sueño de la razón (de la biotecnología, en este caso) produce monstruos. La pregunta clave reside entonces en cuestionarse quiénes son los verdaderos monstruos: aquellos seres que 
fueron modificados para fines bélicos o quienes los crearon.

\section{CONCLUSIONES}

Para cerrar este análisis, se destaca que en la mayor parte de los textos analizados el cíborg alerta sobre los peligros de la tecnología y sus límites éticos (tal y como ocurre, por ejemplo, en "El ejército de Ona$\left.\mathrm{ra}^{\prime \prime}\right)$. En este caso, la incorporación de la tecnología animaliza degrada al que la utiliza y vuelve monstruoso tanto al usuario como al creador.

En tanto, en "Joyería mental" y en "Lunas en vez de sombras", la tecnología resulta incapaz de resolver las preocupaciones inherentes a la existencia humana. Llama la atención también que, en estos casos, la gradación del cíborg no abarca el nivel 3 -según la escala de Grey-, lo cual podría implicar que la humanidad en los personajes no se pone entredicho, a diferencia del texto de Garro. El proceso de convertirse en un cíborg se relaciona más bien en ambos textos con un uso hedonista; la tecnología y las posibilidades que esta brinda para convertirse en cíborg se presentan como un bien de consumo anhelado.

Por su parte, en "Yo la criatura" la subjetividad de Victoria reta por completo las dualidades básicas del pensamiento occidental. Esta transgresión al modelo de humano es un proceso gozoso para Victoria, orgullosa de su monstruosidad. En este caso, el cíborg sale bien librado, ya que consigue sus objetivos (no estar solo, formar una familia).

Como palabras finales, como bien indica Sádaba (2009), ante el eminente auge de los descubrimientos en el área científica y tecnológica, la literatura de ciencia ficción se encarga de presentar al lector esos "futuros imaginados" (p. 31). Estos textos funcionan entonces como un espacio catártico (y por ende, tranquilizador) sobre los miedos en torno a un presente dominado por el conocimiento tecnocientífico, pero además "articulan una auténtica economía política de la esperanza" (p. 231), pues las profecías anunciadas en ellos todavía no llegan, es decir, hay aún tiempo para cambiar el futuro. Además, como advierten Gray (2011) y Chavarría Alfaro (2015), el desarrollo de estas nuevas tecno- logías debe formar parte de una discusión pública y democrática, porque se corre el riesgo de que el debate se haga a puertas cerradas, con la participación de algunos pocos privilegiados. La ciencia ficción (y las reflexiones y preocupaciones inherentes a ella) resulta entonces una valiosa antesala a este diálogo tan necesario.

\section{REFERENCIAS BIBLIOGRÁFICAS}

Alfaro Vargas, R. (2014). El Novum en la ciencia ficción costarricense. Revista de Filología y Lingüística de la Universidad de Costa Rica, 40 (1) 129-140. Recuperado de http://revistas.ucr. ac.cr/index.php/filyling.

Braidotti, R. (2015). Lo posthumano. Recuperado de http://ebookcentral.proquest.com.

Brown, A. (2010). Cyborgs in Latin America. Nueva York, Estados Unidos: Palgrave Macmillan.

Castillo, M., Clark, J., Delgado, M., Ortiz, A., Quijano, L., Ugalde, E. (2011). Objetos no identificados y otros cuentos de ciencia ficción. San José, Costa Rica: EUNED.

Chavarría Alfaro, G. (2015). Poshumanismo y los cambios en la identidad humana. Revista Reflexiones, 94 (1) 97-107. Recuperado de http:// revistas.ucr.ac.cr/index.php/reflexiones/article/ view/20882.

Chaves, J., Clark, J., González Chaves, D., Lippi Rojas, E., Molina Jiménez, I., Rossi, A. (2013). Lunas en vez de sombras y otros relatos de ciencia ficción. San José, Costa Rica: EUNED.

Córdoba Guardado, S. (2007). La representación del cuerpo futuro [Tesis para optar al grado de Doctor en Bellas Artes]. Universidad Complutense; Madrid, España. Recuperado de http:// eprints.ucm.es/7536/.

Cuvardic García, D. (2014). Capitalismo voraz y cuerpos consumidos: distopía postnacional y globalización en Fragmentos de la tierra prometida, de Fernando Contreras. Revista de Filología y Lingüística de la Universidad de Costa Rica, 
40 (1) 115-126. Recuperado de http://revistas. ucr.ac.cr/index.php/filyling.

Eco, U. (1998). De los espejos y otros ensayos. Barcelona: Editorial Lumen.

Gray, C. H. (2011). Homocyborg: cincuenta años después. Teknocultura. Revista de Cultura Digital y Movimientos Sociales, 8 (2) 83-104.

Gray, C. (1999). Human Potencial, the Information Society and Ciborgiation. Recuperado de http:// www.econstor.eu/bitstream/10419/114261/1/ ERSA1999_a124.pdf

Gunn, J. (2005). Speculations on Speculations: Theories of Science Fiction. Lanham-TorontoOxford: Scarecrow Press.

Haraway, D. (1984). Manifiesto cíborg. Descargado desde https://xenero.webs.uvigo.es/profesorado/beatriz_suarez/ciborg.pdf.

Hayles, K. (1999). How we became posthuman: virtual bodies in cybernetics, literature, and informatics. Chicago, Estados Unidos: University of Chicago Press.

Malmgren, C. D. (1988). Towards a Definition of Science Fiction. Science Fiction Studies 15 (46): 259-281.

Mejía, I. (2005). El cuerpo poshumano en el arte y la cultura contemporánea. México: UNAM. Recuperado de http://es.scribd.com.

Molina Jiménez, I. (2015). León Fernández Guardia y "El número 13,013". Alambique: Revista académica de ciencia ficción y fantasía, 3 (1) 1-15. Recuperado de http://scholarcommons.usf.edu/ alambique/vol3/iss1/1/.

Molina Jiménez, I. (enero, 2010). Género en construcción: la ciencia ficción costarricense. A propósito de Vuelo de Ra, de Manuel Delgado. Acontracorriente. Revista de Historia y Literatura en América Latina, 8 (1) 408-415. Recuperado de http://www.ncsu.edu/project/acontracorriente.

Moreno, F. (2010). Teoría de la Literatura de Ciencia ficción. Poética y retórica de lo prospecti- vo. Vitoria, España: Portal Editions. Recuperado de https://www.academia.edu/11817054/ Teor\%C3\%ADa_de_la_Literatura_de_cf_primera_edici\%C3\%B3n_

Pacheco Solórzano, C. (enero-junio, 2014). Discursos literarios en Costa Rica. Revista Espiga, 13 (27), 59-66. Recuperado de investiga.uned. ac.cr/revistas/index.php/espiga.

Ruiz Ulloa, G. (2014). Entredichos de la sociedad democrática costarricense: Ciencia ficción y política. Revista de Filología y Lingüística de la Universidad de Costa Rica, 40 (1) 107-112. Recuperado de http://revistas.ucr.ac.cr/index.php/ filyling.

Sádaba, I. (2009). Cyborg. Sueños y pesadillas de las tecnologías. Barcelona, España: Ediciones Península.

Soto Bogantes, C. (2014). El mundo natural y el futuro de la colonialidad: "Frente frío" de Jessica Clark y "La flor del crepúsculo" de Laura Quijano. Revista de Filología y Lingüística de la Universidad de Costa Rica, 40 (1) 87-95. Recuperado de http://revistas.ucr.ac.cr/index.php/filyling.

Víquez Jiménez, A. (2014). Lectura de dos relatos de ciencia ficción costarricense "Órdago" y "Objeto no identificado". Revista de Filología y Lingüística de la Universidad de Costa Rica, 40 (1) 87-95. Recuperado de http://revistas.ucr. ac.cr/index.php/filyling. 


\title{
"Te extraño, te olvido, te amo de nuevo". La construcción del amor en la literatura juvenil argentina
}

\author{
Por: Licda. Giulana A. Pates ${ }^{1}$, Universidad de La Plata, Argentina
}

Recibido: 14 de febrero, 2018

Aceptado: 19 de abril, 2018

\section{RESUMEN}

Recociendo que para analizar objetos literarios es necesario desbordar los límites del texto, este artículo apunta a indagar en las mediaciones existentes entre la literatura y el entramado social, es decir, los rasgos específicos del texto literario y la red de relaciones de la que es parte. En particular, se centrará en la literatura juvenil romántica argentina para preguntarse cómo está configurado este campo, qué matrices discursivas en torno del amor se construyen y cómo es leída y apropiada por parte del público lector juvenil. Para ello se analizarán los libros S.O.S. Tengo mi primera cita (Dritsos, 2014) y Diario de una ruptura (Dritsos, 2016).

En primera instancia, se contextualizarán los libros seleccionados dentro del mercado editorial argentino y se recuperará la trayectoria de su autora para dar cuenta de sus condiciones sociales de producción. En segundo lugar, se desglosará el análisis de ambos libros en torno a los modos en que se construye el amor a partir de dos matrices discursivas: el amor romántico y el amor contingente. Finalmente, se reconstruirán los espacios por donde han circulado estos libros, así como también los modos en que han sido leídos y apropiados en Argentina.

\section{ABSTRACT}

\section{"I miss you, I forget you, I love you again." The construction of love in Argentinian young adult literature}

When we analyze literary objects, it is necessary to go beyond the limits of the text. This article aims to look at the mediations between the literary and social frameworks; that is to say, the specific features of the literary text and the relationship network to which it belongs. We shall focus specifically on Argentinian romantic young adult literature to reflect on how the literary field is built, what discursive matrices on love are constructed, and how it is read by young readers. To do so, Georgina Dritsos' books S.O.S. Tengo mi primera cita (2014) and Diario de una ruptura (2016) shall be analyzed.

First of all, these two books shall be set within to the Argentinian editorial market as well as the author's literary career will be mentioned. Secondly, the ways in which love is constructed in both books will be analyzed following two discursive matrices: romantic love and contingent love. Finally, the places where the books have circulated and the ways they have been read in Argentina it shall be summarized.

1 Giulana Pates es licenciada en Comunicación Social con orientación en Planificación Comunicacional, graduada de la Universidad Nacional de la Plata, Argentina. Actualmente realiza su tesis para optar por la maestría en Sociología de la Cultura y Análisis Cultural, en la Universidad Nacional de San Martín, Argentina. Contacto: giulianapates@hotmail.com. 
"Te extraño, te olvido, te amo de nuevo". La construcción del amor en la literatura juvenil argentina

Construir objetos de estudio literarios no implica que preguntarse únicamente por el modo en que están escritos los textos o la biografía de su autor. Si bien pueden constituirse en dimensiones a indagar, un abordaje que pretenda no ser parcial invita a asumir una mirada que exceda el análisis textualista. En este sentido, se entiende que el objeto de estudio tiene que ser el hecho literario en tanto hecho social, es decir, inscripto en relaciones sociales y el marco de una sociedad y una cultura específicas, en donde participan sujetos e instituciones. No hay una separación dicotómica entre un "adentro" literario, textual y un "afuera" social, extratextual. Se debe atender las relaciones que se entablan entre estos dos espacios que no son externos entre sí, sino que se implican mutuamente.

Para ello, la perspectiva de la sociología de la literatura permite entender la significación de una obra más allá de las intenciones de su autor o su construcción interna. Articular las herramientas de la sociología y la literatura ayuda a acercarse a una constelación de productos que se reúnen bajo la categoría de literatura e inscribirla en un contexto de producción y circulación más amplios. El desafío, permanente y dialógico, transformado en abordaje metodológico, consiste en atender el universo delimitado por el texto -sus rasgos de constitución específicos- y la red de relaciones que lo insertan en el entramado social.

Siguiendo esta línea propuesta por la sociología de la literatura, se señalan tres ámbitos de indagación en donde se focalizará el artículo para preguntarse por las mediaciones entre las obras literarias y los contextos socio-históricos de los que son parte. Por un lado, las condiciones sociales de producción de las obras, entendidas como las relaciones de la literatura con otros campos sociales, así como también la organización del campo literario -sus instituciones, las posiciones que ocupan los autores, sus trayectorias y vínculos de sociabilidad, y las formaciones culturales-. En segundo lugar, la puesta en forma de los textos literarios, es decir, las maneras de hacer literarias, las elecciones formales y genéricas dentro del "espacio de posibles" (Bourdieu, 1992) de una época y lugar dados que refractan el mundo social. Por último, las condiciones de circulación y apropiación de las obras literarias, así como sus usos dentro o fuera del campo literario (Sapiro, 2016).

Desde este posicionamiento teórico y metodológico -entonces- y como parte de una investigación más amplia en el marco de la tesis doctoral de quien escribe este artículo, en torno a la literatura juvenil romántica², se abordará aquí el caso de dos libros juveniles argentinos de reciente publicación: S.O.S. Tengo mi primera cita (2014) y Diario de una ruptura (2016), ambos escritos por Georgina Dritsos, para preguntarse por esa red de relaciones formada entre estos textos y el entramado social. En este sentido, no es este un análisis lingüístico que ahonde en las formas de la escritura de los libros ni se hará una evaluación de su calidad estética. Se plantea, en cambio, poner en relación estas producciones literarias con su contexto sociocultural y las posibilidades históricas que permitieron que se escribieran y editaran.

Por tanto, este artículo partirá de presentar y describir los modos de producción de la literatura juvenil en Argentina, centrándose en la editorial que ha publicado los dos libros seleccionados y la inscripción de su autora en el campo literario. A continuación, se analizarán estas producciones con la intención de indagar los sentidos sociales en torno del amor que ellas refractan a partir de las elecciones genéricas y formales realizadas. Finalmente, se planteará un acercamiento a sus condiciones de circulación y apropiación en el campo literario.

\section{COORDENADAS DE LA LITERATURA JUVENIL ARGENTINA}

Poner la mirada en las condiciones sociales de producción de las obras literarias obliga a prestar atención a la situación de la literatura, en este caso juvenil, respecto de otros espacios sociales, así como

2 Desde el 2017, la autora cuenta con una beca doctoral del Consejo Nacional de Investigaciones Científicas y Técnicas (CONICET), cuyo título es "Por ese palpitar. Las experiencias de lectura de literatura romántica de circulación masiva como nueva adscripción identitaria juvenil", bajo la dirección de la Dra. Florencia Saintout y cuyo lugar de trabajo es el Instituto de Estudios Comunicacionales en Medios, Cultura y Poder "Aníbal Ford". A parti de ella, se propone analizar las matrices culturales del amor que se construyen en las novelas juveniles románticas contemporáneas, así como también indagar en las experiencias de lectura de estas por parte de jóvenes de sectores medios urbanos de la Ciudad Autónoma de Buenos Aires (CABA) y La Plata, en Argentina. 
también su organización interna. La literatura como espacio de producción cultural se ha autonomizado a partir de la profesionalización de los escritores, la creación de instituciones específicas que la regulan y marcan sus límites (desde la escuela y la universidad que la construyen como un saber académico hasta las organizaciones y academias profesionales, los eventos como ferias y festivales hasta la otorgación de premios), la formación de un cuerpo de especialistas y la constitución de un mercado propio.

La literatura juvenil, en particular, es motivo de reflexión en el campo pedagógico, porque parte de su circulación se da dentro del sistema escolar, es objeto de estudio de investigaciones académicas y es uno de los géneros más rentables para el mercado editorial local. Respecto de este último punto, partiendo de los datos que proporcionan los informes y las estadísticas anuales construidas por la Cámara Argentina del Libro, se sostiene que la publicación de Literatura Infantil y Juvenil (LIJ) ha aumentado en cantidad de títulos en los últimos años, posicionándose como uno de los tres sectores más editados en el país. En los últimos ocho años, ha representado entre $15 \%$ y $18 \%$ del total de libros publicados y registrados en la Argentina, mientras que en el Sector Editorial Comercial (SEC) alcanzó 22\% en el primer semestre del 2017. En los informes, las editoriales son clasificadas en tres sectores: Sector Editorial Comercial, Autoedición y Otros, en donde se incluyen microemprendimientos, instituciones educativas y entidades públicas. Cabe destacar, además, que la literatura (narrativa y poesía) representa entre $20 \%$ y $25 \%$, y las Ciencias Sociales/Humanas, entre $20 \%$ y $24 \%$, de acuerdo con los datos proporcionados en los informes anuales de producción del libro argentino.

Si bien la literatura juvenil tiene una cantidad menor de libros publicados que los de literatura infantil -se los considera dentro de una misma categoría en estos informes-, el número de literatura juvenil en circulación aumenta si se incorporan al análisis las publicaciones extranjeras, sobre todo las norteamericanas, inglesas y españolas, que son las que más se venden en este sector. Así, se puede ver que el $16 \%$ de los libros más vendidos durante el año 2014 pertenecieron a la LIJ, y el 86\% de esa porción fueron novelas juveniles (Cámara Argentina de Publicaciones, 2015).

En este marco de producción editorial es que se ubican los dos libros que se proponen analizar: S.O.S. Tengo mi primera cita (2014) y Diario de una ruptura (2016), ambos escritos por la escritora, periodista y Community Manager Georgina Dritsos, y editados por V\&R Editoras. Esta editorial se fundó en 1996 en Argentina y en los últimos años, abrió sucursales en México y Brasil, lo que le posibilitó ampliar la distribución de sus libros en el resto de América Latina, así como también en Estados Unidos y España. Forma parte del Sector Editorial Comercial (SEC), que representa el $42 \%$ de las ediciones en Argentina, dentro del cual la concentración por cantidad de ejemplares y novedades editadas se reduce principalmente a seis editoriales: Planeta, PenguinRandomHouse, Grupo Prisa, Holtzbrinck, Longseller y Thompson Reuters (Cámara Argentina de Publicaciones, 2015).

V\&R Editoras, en particular, se caracteriza por editar publicaciones infantiles y juveniles, desde libros para colorear hasta novelas, asimismo, por tener en su catálogo libros y agendas de autoayuda y coaching para el público adulto. Este tipo de publicaciones goza de mayor prestigio comercial que estético, es decir, su valoración está dada por la cantidad de libros vendidos. No obstante, no son reconocidos como productos con legitimación cultural y literaria por parte de los sectores más especializados del campo: no son reseñados en revistas de crítica literaria ni incluidos en los programas de la carrera de Letras, tampoco reciben premios de academias literarias. Esto hace que su posición en el campo esté legitimada por el mercado, pero no por la crítica o los ámbitos académicos.

El catálogo de $\mathbf{V} \& \mathbf{R}$ Editoras está formado por varias colecciones: Jóvenes Lectores (romance, romance paranormal, fantasy, thriller/misterio, realista, ciencia ficción, distopía, realismo mágico, drama, autobiografía, New Adult), Preadolescentes (ficción: fantasy, aventuras, ChickLit; no ficción: para chicos aventureros; solo para chicas; 1.000 datos de...; libros de villanos y mentiras; libros interactivos), libros infantiles, inspiración (libros de autoayuda y coaching), libros regalos (libros pensados para 
"Te extraño, te olvido, te amo de nuevo". La construcción del amor en la literatura juvenil argentina

regalar en el día del padre, de la madre, del amigo), libros para colorear, cocina y agendas.

Con respecto a la posición de la autora, Georgina Dritsos, se puede decir que estos son sus primeros y hasta el momento, dos libros editados que le permitieron ser reconocida como escritora. Antes de publicarlos, se especializaba en temáticas juveniles y femeninas, siendo redactora en medios gráficos como Clarín y las revistas para jóvenes LunaTeen y Txt, así como también en las editoriales Atlántida, Perfil y Capital Intelectual. Se desempeñó, además, como subeditora de la revista Luna Teen y actualmente es jefa de prensa de $\mathbf{V} \& \mathbf{R}$ Editoras. Su inserción en el campo literario está posibilitada, entonces, por su trabajo en la editorial y posteriormente, por su condición de escritora. Asimismo, su trayectoria como periodista y su participación en editoriales y revistas juveniles, recorrido que compartía con Cristina Alemany, directora editorial de V\&R en el momento de publicarse los libros, facilitó su posicionamiento.

Finalmente, respecto de las condiciones de producción de las que participó, es posible decir que las publicaciones de estos libros forman parte de un mercado ya constituido, que cuenta con algunas lógicas propias: la oferta de escribir viene organizada por parte de la editorial, a la vez que la fecha de su publicación es pautada con anterioridad. En este sentido, la autora tiene que adaptarse a unas condiciones ya dadas. En el siguiente fragmento, extraído de una comunicación personal con la autora (no publicada, realizada el 4 de diciembre de 2016) da cuenta de que la escritura y edición de su primer libro estuvo sujeta a los plazos de la editorial, permitiendo ver la íntima relación entre producción literaria y mercado:

Realicé toda la producción previa que requiere un libro, pero hacía todo con mucha tranquilidad, sin apurarme. Ya había empezado a escribir pero me lo tomé sin apuro, hasta que un día en la editorial me dijeron: 'está confirmado que tu libro está en el plan de publicaciones para salir en tal fecha, ¿cómo vas con la escritura, vas a llegar a tiempo?'. Ahí recién caí en la cuenta de que iba a haber un libro, que sí lo iban a publicar y que iba a tener que acelerar el proceso. Por suerte, pude terminar de organizar la información, seleccionar los temas, los capítulos y terminar de escribir y de redondear todo como para entregar a tiempo el texto final (entrevista realizada a la autora en el marco de esta investigación en diciembre de $2016^{3}$ ).

\section{LA REFRACCIÓN DEL MUNDO SOCIAL: ¿QUÉ DICEN ESTOS LIBROS RESPECTO DEL AMOR?}

S.O.S. Tengo mi primera cita se publicó en el 2014 y forma parte de la línea No Ficción - Solo para chicas de la colección "Preadolescentes" que tiene la editorial. Es una guía escrita para mujeres de ese rango etario que van a tener su primera cita con un varón. Para ello, la autora da consejos de cómo prepararse y comportarse en la cita. Además, ofrece tests para saber si la lectora está preparada y si el chico está interesado en ella. Finalmente, recomienda una lista de películas norteamericanas, de género comedia romántica, para que las lectoras puedan seguir profundizando sus conocimientos al respecto. Según la autora en la entrevista realizada, "trata sobre todos los temas que hacen a ese momento de la vida cuando te empiezan a gustar los chicos y no tenés ni idea de cómo manejarte, de qué hacer, qué decir en una cita, qué no decir".

Por su parte, Diario de una ruptura se publicó en el 2016 y es clasificado dentro de la línea "Ficción - ChickLit" también de la colección "Preadolescentes". Este libro está dividido en dos partes: la primera es una breve ficción acerca de Brenda, una chica de dieciocho años cuyo novio cortó la relación por medio de un mensaje de texto. Se narra, a modo de diario íntimo, qué hace el personaje en esa situación de ruptura junto con sus amigos y familiares. La segunda parte es una guía de qué hacer y qué no durante el proceso de una ruptura. Se dan consejos y recomiendan películas y canciones para atravesar ese momento. La idea de este libro -según contó la autora en la entrevista- "surgió al terminar el primero. Acordamos con la editorial que escribiría sobre las rupturas amorosas, sobre qué le pasa a una persona cuando corta una relación, cómo se siente,

3 A partir de aquí, todas las transcripciones que se hagan de su voz remitirán a esta entrevista inédita. 
cómo se puede salir adelante y todo eso que nos sucede cuando nos rompen el corazón".

El género "ChickLit" es aplicado a la literatura escrita por y para mujeres que narra, en un tono personal y humorístico, la vida cotidiana de la mujer, abordando temas como el amor (citas, relaciones, matrimonio) la amistad, el trabajo (compañeros, expectativas), representaciones de la belleza (peso, depilación, vestimenta). La denominación surgió para clasificar como "infantiles" y "banales" las columnas que publicaban las mujeres en diarios y revistas, pero se convirtió en un modo particular de referenciar productos de la industria cultural (columnas periodísticas, novelas, películas, series), sobre todo a partir del éxito de "Sex \&The City" y de "El diario de Bridget Jones", representantes paradigmáticas de este género.

Al detenerse en los capítulos no ficcionales, se puede encontrar una continuidad entre las narrativas de cierto tipo de revistas juveniles y estos libros, que se facilita por el catálogo de la editorial y la trayectoria de la autora, pero también por el modo en que están narrados y los recursos que elige: guía de acciones, tests, testimonios en primera persona, recomendaciones musicales, cinematográficas, de vestimenta. Dicho en otras palabras, estos apartados de ambos libros presentan una continuidad con las secciones habituales de las revistas juveniles contemporáneas dirigidas a mujeres, como pueden ser Seventeen, Para Teens, TKM, Luna Teen, Txt, de las que su autora participaba. Dice Dritsos (2014) al respecto:

Provengo del periodismo y mi trabajo anterior fue como subeditora a cargo de una revista para jóvenes y adolescentes donde solía escribir textos sobre el amor, los vínculos, sobre sexualidad, sobre la amistad y otros temas, así que estos libros son un poco una prolongación de toda aquella experiencia previa.

Recuperando los aportes de Mijaíl Bajtín (1982) en torno a los géneros discursivos y la novela en particular, es posible advertir que son formas de la plurivocidad propiamente literaria que convoca a discursos pertenecientes a esferas discursivas distintas y mezclados en un nuevo producto. Esta hibrida- ción - es decir, este "sistema de fusión de lenguajes, literariamente organizado" (Bajtín, 1978, citado en Altamirano y Sarlo, 1993, pp. 68-69)- puede construir lo que Bajtín denominó "géneros intercalados". Estos géneros construyen una conciencia galileana, descentrada, que relativiza los límites entre los géneros (Altamirano y Sarlo, 1993).

Ahora bien, ¿qué es "lo literario" en estos libros? ¿Por qué son considerados literatura si utilizan, en gran parte, el discurso de las revistas juveniles? En primer lugar, podría decirse que se debe a que la incorporación de otros discursos está subordinada a una función estética y es esta la que prima en los libros. Su predominio, entonces, no excluye la actividad simultánea de otras funciones. Si hay tests, instructivos, recomendaciones, es en la medida en que contribuyen a construir una narración acerca de la primera cita o la separación con una pareja, según cada libro. Pero como se mencionó al principio, no se puede definir una obra literaria por la mera descripción de sus elementos, sino que es necesario pensarla en relación. Siguiendo a Williams (1977), "es preciso rechazar 'lo estético' tanto como dimensión abstracta separada o como función abstracta separada. Es preciso separar la 'Estética' en la medida en que se apoya en estas abstracciones. Al mismo tiempo se debe reconocer y, aún más, subrayar las intenciones específicas variables y las respuestas específicas variables que han sido reconocidas como estéticas" (Williams, 1977, citado en Altamirano y Sarlo, 1980, p. 45). En este sentido, su definición viene anudada a lo que la sociedad -O por lo menos un sector especializado de ella- asigne como estético y por lo tanto, literario en un momento dado. ¿Hubieran sido considerados literarios estos libros en otro momento sin la legitimación de los discursos que convoca? Probablemente, no.

Avanzando con el análisis de la puesta en forma de estas obras, se dice que son libros juveniles que tematizan el amor. Toda obra literaria se inserta en un espacio discursivo más amplio, del que se nutre y al que construye. En otras palabras, se puede leer en la literatura un doble juego: a) la incorporación de discursos y saberes contemporáneos, es decir, la refracción del mundo social y b) la constitución de la literatura en tanto fuente de las representaciones de una época (Sapiro, 2016). 
"Te extraño, te olvido, te amo de nuevo". La construcción del amor en la literatura juvenil argentina

En este sentido, se evidencia que estos libros recuperan matrices discursivas respecto del amor que circulan socialmente. Se entiende que una matriz discursiva funciona como un "molde" que da forma a la enunciación. Los elementos que formen parte de la matriz pueden variar según las circunstancias, hacerse foco en unos más que en otros, pero mantiene una estabilidad. Al inscribirse en determinada matriz discursiva, los enunciados tienen rasgos comunes, así como límites que marcan lo que es posible decir y lo que no dentro de ese molde. Siguiendo lo que plantea Arnoux (2008, p. 11), "'matriz discursiva' remite tanto a un espacio de regularidades generador de discursividad como a un molde que permite dar forma discursiva a datos diversos e, incluso funcionar como grilla interpretativa de lo social".

Una de las matrices que se recupera y reconstruye en los libros es la matriz del amor romántico. Este tipo de amor propone a la pareja como la "media naranja" o el "alma gemela", a la que se le debe y exige exclusividad a cambio de un amor único e insustituible que completa al sujeto. En esta línea, se demanda fidelidad y se construye un tipo de subjetividad como "ser para otro" (Fernández, 1993). Así, supone y construye relaciones desiguales entre "lo masculino" y "lo femenino", depositando en el primero mayor autonomía y en el segundo, subordinación a través de una fragilización de su subjetividad. En este marco, "lo masculino" está asociado con la seguridad, la comprensión, la perfección, mientras que "lo femenino", con la inseguridad, la vulnerabilidad y la fragilidad.

S.O.S. Tengo mi primera cita en principio está destinado solo a chicas, desde la clasificación de la editorial y el uso de los pronombres femeninos por parte de la escritora, como si fuesen las mujeres las únicas que necesitaran una ayuda que las organice y les diga qué hacer en situaciones que implican una relación erótico-afectiva. En un cruce de las condiciones de género y edad, las mujeres jóvenes son construidas como inseguras, miedosas, nerviosas y alteradas en tanto piden ayuda -el pedido S.O.S. ya está inscripto en su título- para salvarse. Se puede ver esta construcción en el inicio del libro:
Todavía faltan varias horas para LA cita con ÉL... No hay ninguna prisa. La casa está tranquila, pero en tu interior estás muerta de miedo, nerviosa, alterada. Tu cabeza es un torbellino de pensamientos, de inseguridades. No puedes evitar pensar: ¿y si algo sale mal? ¿Si no la paso bien con él? ¿Y si no me gusta? ¿O si no le gusto y me deja plantada en el medio de la cita? O peor aún: ¿si ni siquiera viene a buscarme? iißSocorroooo!!! (se respeta el subrayado de la publicación). (Dritsos, 2014, p. 3).

En esta línea, también se refuerza la cis-heteronormatividad -el libro describe a una chica que espera encontrarse con "ÉL", en mayúscula, grande, fuertey en paralelo, propone relaciones desiguales entre hombres y mujeres: mientras se sigue asociando la mujer con los sentimientos y las emociones, fragilizando su subjetividad (Fernández, 1993), se reafirman y legitiman algunas prácticas machistas de los hombres.

En uno de los apartados de la publicación se construye una tipología de los chicos - deportistas, mujeriegos, nerds, nenes de mamá, depresivos, histriónicos-y el manipulador es descripto como un hombre que "monta un berrinche por cualquier cosa", "lo que quiere es manejarte", "es celoso y posesivo" y "se quejará en voz alta si no haces las cosas a su manera". La descripción termina diciendo que este tipo de chico "no es apto para chicas con personalidad fuerte" (Dritsos, 2014, p. 20). ¿Acaso sí es apto para las chicas sumisas? Dentro de esta matriz, los celos y los deseos de posesión no están inscriptos en un entramado de relaciones de poder desiguales entre hombres y mujeres, sino como dinámicas propias de una relación erótico-afectiva.

Del mismo modo, en el apartado del libro que reconstruye los momentos previos a la cita, se reproduce un posible diálogo familiar en el que el padre asegura:

"¡Ponte cualquier cosa menos una de tus minifaldas si no, no te dejo salir!" y se agrega más adelante: "¡Ah! Y no te olvides de decirle a ese inútil que soy cinturón negro de karate (papi no hace karate desde los 
18 años, ipero está convencido de que es el mejor karateka del planeta!)". (Dritsos, 2014, p. 7).

Así, mientras que la mujer es vinculada con los sentimientos, el hombre lo es con la fuerza, la violencia y la autoridad. Esta matriz, entonces, construye y sostiene un orden social jerarquizado, "un orden, asimismo, heterosexual, que implica no solo privilegiar una forma de deseo frente a otras posibles, sino una forma de entender las relaciones entre lo masculino y lo femenino absolutamente dicotómica y complementarista" (Esteban, 2011, p. 48).

Por su parte, esta matriz romántica también está presente en Diario de una ruptura, el segundo libro de Dritsos. La primera parte, como se mencionó, es una breve historia ficcional que -a modo de diario personal- aborda los días posteriores a la ruptura de un noviazgo de un año y medio. La segunda tiene una perspectiva similar al primer libro, es decir, se posiciona como una guía para "curar el corazón roto".

La historia ficcional comienza con el mensaje de texto que le envía Alex (de 24 años, "inteligente, atractivo y candidato perfecto", estudiante de Derecho con el mejor promedio de su año) a Brenda, una chica de 18 años que acaba de terminar la escuela secundaria, no sabe qué va a estudiar y "por primera vez en su vida está enamorada". A partir de aquí se la describe como "intranquila", en un "estado de nervios y ansiedad", con el corazón "latiendo a mil por horas", con "ganas de querer matarlo", "los ojos llenos de lágrimas y la cabeza abombada" y "furiosa". Como la historia es contada desde la perspectiva del personaje femenino, no se hace mención a los sentimientos y las emociones de Alex. Solo se incluyen las palabras que envió por mensaje de texto: "Lo nuestro terminó, Bren. Ya no quiero estar contigo. $Y$ no llores, no es el fin del mundo. Suerte en tu vida. Adiós". (Dritsos, 2016, p.8).

La construcción de esta voz narradora, dentro del repertorio de posibles, pone el acento en Brenda, con un estilo de escritura íntima y subjetiva: solamente se sabe lo que va ocurriendo través de la mirada del personaje femenino. Este gesto, a la vez que ubica a una mujer como protagonista, privilegia la narración de sus sentimientos y obtura los sentimientos en el personaje masculino. Podría decirse, hasta aquí, que las emociones siguen siendo territorio exclusivo de las mujeres, mientras que a los hombres se les quita la capacidad de sentir. Su ámbito es el de las palabras, el de la racionalidad. El personaje masculino supone a priori que Brenda, en tanto mujer, va a llorar al leer el mensaje de texto. Él - en cambio- puede decir con tranquilidad que "no es el fin del mundo".

Al mismo tiempo, es posible afirmar que se sostiene la construcción de una relación desigual y asimétrica en donde las mujeres siempre representan la subalternidad: Brenda es más chica y más inexperta mientras que Alex es "inteligente y le espera un futuro brillante", "muuuuy bonito, tanto que ahora duele recordarlo", "gran deportista y tiene el cuerpo marcado", "buen hijo, buen hermano, buen amigo", es decir: "perfecto". (Dritsos, 2016, p. 41). Se construye, de este modo, una hipermasculinidad más poderosa que encanta a las mujeres y las posiciona en un lugar dominado, tanto que son siempre ellos los que toman la decisión de terminar con la relación, de "dejar" lo que ya tuvieron por otra mujer.

Ahora bien, entendiendo que los productos culturales pueden ser heterogéneos y complejos, esta matriz no es la única que emerge en los libros. Es decir, la narración oscila entre una matriz de amor romántico -tal como se ha analizado hasta aquíy una matriz que se llamará de amor contingente. Estas matrices discursivas conviven entre sí, no sin contradicciones, en los libros.

En la matriz del amor contingente se revisan algunas de las premisas del amor romántico y se plantean formas diferentes del devenir de la relación eróticoafectiva. En principio, a diferencia de la primera matriz, que supone la pasión eterna en la pareja o por lo menos, una perdurabilidad "hasta que la muerte nos separe", las relaciones erótico-afectivas pueden tener una duración finita. Se rompe, de este modo, con la premisa de la predestinación de los amantes, así como su duración para toda la vida. 
"Te extraño, te olvido, te amo de nuevo". La construcción del amor en la literatura juvenil argentina

Yendo a los libros, en S.O.S. Tengo mi primera cita, uno de los apartados propone las derivas que puede tener ese primer encuentro: puede ser que no se conozca al amor de la vida, puede ser que no implique el inicio de una relación, puede incluso ser insignificante. Dice la autora:

Toda cita es un "riesgo", en el sentido de que puede salir bien, mal o ser simplemente un momento más que pasa sin pena ni gloria en tu vida. Si una no se quiere "arriesgar", es decir, exponerse, más vale quedarse en casa, en donde no te "arriesgarás" a que alguien te deje plantada, o a pasar un rato con un chico que, quizás, finalmente no te interese, entre otras situaciones posibles... pero tampoco vivirás la vida como se supone que hay que hacerlo: viviéndola a pleno. Como dice el dicho: "el que no arriesga no gana" (Dritsos, 2014, p. 13).

Asimismo, esta matriz no sostiene la construcción de un orden desigual y desjerarquizado entre hombres y mujeres: los hombres no son, necesariamente, perfectos y las mujeres no son, necesariamente, sensibles. En cambio, se habilita una constelación de prácticas y representaciones de lo femenino que, en la matriz romántica, estaban obturadas.

En Diario de una ruptura, a la semana de terminar la relación con su novio, Brenda viaja a la casa de su abuela Dora, que está ubicada en un pueblo costero. Su abuela, lejos de responder a las representaciones hegemónicas en torno a la adultez, es "joven y cool": "toca la guitarra, algo de piano y baila música electrónica. Además, practica yoga, es una gran lectora, una excelente cocinera y aparenta unos diez años menos de los que tiene", usa Facebook y Skype, tiene tatuajes, está casada por tercera vez y se la muestra con una vida sexual activa (Dritsos, 2016, p. 24). De este modo, se construye un tipo de feminidad adulta que no se corresponde con las actividades esperables para su género y su generación: cuidado de la familia y el hogar, tareas manuales, consumos culturales de otra época, un cuerpo inmóvil, el placer y el goce obturados. En cambio, hay una construcción juvenilizada, como una nueva expectativa para el ciclo vital de las mu- jeres, que la convierte en "una mujer fuerte, decidida; una muñeca brava" (Dritsos, 2016, p.44).

En esta misma línea, en el devenir de la historia se presenta la ruptura como un momento doloroso para Brenda, pero también como una oportunidad para salir "fortalecida" y descubrirse a sí misma. En este argumento, todo momento, por más angustiante que pueda resultar, es visto como una oportunidad de aprendizaje y crecimiento. En el caso de Brenda, es una oportunidad para darse cuenta de que Alex no era "perfecto" como lo creía, sino celoso y posesivo. Más importante aún fue lograr prestarle atención a aspectos de su vida que antes no hacía o no se animaba, por ejemplo, observar su cuerpo y descubrir que está conforme con él. Al final del libro, este personaje reflexiona:

Lo que sí tengo en claro es que no voy a descuidar otros terrenos de mi vida que son importantes para mí, tanto o más que el amor. Me refiero a mi futuro profesional. Apenas pueda voy a inscribirme en la carrera de Letras que es mi verdadera vocación: la literatura y, a futuro, mi deseo es ser escritora. ¡Ah! También voy a comenzar a tomar clases de danzas árabes con Lara [su amiga], algo que quiere compartir conmigo desde hace tiempo y yo, por miedos e inseguridades, siempre me negué a hacer (Dritsos, 2016, p. 50).

Ahora, en el centro de su vida están sus deseos y proyectos, y el amor es solo una parte. De este modo, ya no se enfatiza el amor por delante de otras facetas humanas ni se busca la felicidad y realización personal en una relación erótico-afectiva, como propone el amor romántico (Esteban, 2011). El consumo musical, de películas, estar con amigos y familiares, y escribir diarios personales le permitieron reflexionar sobre sí misma y sus relaciones, autorrepresentarse y desplegar algunas prácticas para modificar sus emociones y transitar de un estado anímico indeseado a otro en el que "no está tan mal". En este punto, también podría decirse que el amor no aparece como la única preocupación femenina, pero sí emergen otros mandatos de género actuales: la realización profesional y la independencia económica. 
Anudada a esta matriz del amor contingente, es posible encontrar la incorporación en la narración de un discurso de autoayuda en tanto exaltación de la subjetividad y constitución de una guía práctica para superar obstáculos. Aunque estos libros no asuman esa clasificación genérica, se inscriben en un discurso que se extiende más allá de sus publicaciones específicas.

El discurso de autoayuda se constituye en un lugar que orienta la acción de los sujetos en momentos críticos de sus trayectorias y los ayuda a resolver los malestares subjetivos que devienen de ellos. Si bien -como sostiene Vanina Papalini (2015, p. 25)- estas narrativas pueden funcionar como un "dispositivo adaptativo" que "renueva la adhesión a la sociedad instituida" y ubica al yo en el centro de los problemas y las soluciones, también puede ser un apoyo y un acompañamiento en determinados momentos de la vida y producir un posible empoderamiento personal.

Como plantea Illouz (2010):

(...) tanto las novelas como la literatura de autoayuda, cada una de diferente manera, ofrecen escenarios a través de los cuales los actores pueden ensayar cognitivamente su experiencia emocional y reflejarse en las transacciones y en las expresiones emocionales de otros. Al hacerlo, los actores otorgan sentido a sus propios sentimientos (y a los de otros), prescriben sutilmente reglas para tratar con las emociones y proporcionan un vocabulario y un método de introspección (p. 33).

Se puede ver, entonces, que los géneros literarios -como todo género discursivo- no son individuales ni singulares, obra de un sujeto aislado, así como tampoco son estructuras homogéneas y estáticas. Son más bien formas dinámicas, ligadas a las prácticas sociales y sujetas a las transformaciones que devienen en la práctica (Di Stéfano, 2015). Esto habilita que la definición de un género varíe en el tiempo, incorpore elementos de otras esferas discursivas y se tensionen sus propios límites.

\section{CIRCULACIÓN, APROPIACIONES Y LECTURAS}

Esta tercera dimensión de análisis -que busca indagar en la circulación y la recepción de las obras literarias- parte de sostener que el sentido de ellas no se reduce a las intenciones de su autor, sino que se completa en las apropiaciones que de ellas hagan los lectores. Como la recepción es un proceso que desborda el marco de la producción de la obra en el tiempo y el espacio -porque hay reediciones, traducciones, relecturas-, es necesario contemplar el contexto socio-histórico en el que se inscribe el estudio de las apropiaciones.

A su vez, no pueden negarse las mediaciones que intervienen en este proceso: edición (inscripción en un catálogo, redacción de la contracubierta, diseño), espacios de circulación (editoriales, librerías, ferias del libro), clasificaciones que realiza la crítica literaria y la prensa, la difusión y consagración (volumen de ventas, premios, consagración institucional). En este sentido, las obras literarias son mediatizadas por las interpretaciones por parte de agentes individuales o institucionales, profesionales como críticos, revistas, jurados, academias o lectores fuera del campo literario, pero con incidencia en el espacio público, como el periodismo.

V\&R Editoras, como se mencionó, pertenece al Sector Editorial Comercial y su circulación también está dada por espacios comerciales hegemónicos: en las cadenas de librerías más grandes de Argentina y las principales ferias del libro del país: la Feria Internacional del Libro de Buenos Aires y la Feria del Libro Infantil y Juvenil, en donde cuenta con stand propio y la posibilidad de organizar actividades todos los días. También tiene sedes en México y Brasil, y distribuye sus libros en América Latina y Estados Unidos. Para los fines de este texto, se recortará el análisis a la recepción que tuvieron ambos libros en Argentina.

Entendiendo que la apropiación de las tecnologías digitales ha habilitado prácticas que trascienden la lectura individual y silenciosa de las obras literarias, en tanto permite que se creen clubes de lectura en plataformas como Lectorati y Goodreads, se publiquen reescrituras -conocidas como Fan Fictionsque pueden luego convertirse en libros (como es el caso de 50 Sombras de Grey, de E.L. James), se 
"Te extraño, te olvido, te amo de nuevo". La construcción del amor en la literatura juvenil argentina

abran canales de YouTube y cuentas en blogs dedicados a la reseña de ellas, lo que da lugar a un nuevo modelo de lector y de crítico (los booktubers y los bookbloggers), es que se puede afirmar que las formas de recepción de la literatura se constituyen en la interface entre lo online y lo offline.

Esto exige -entonces- construir herramientas metodológicas que permitan acercarse a estas prácticas. La etnografía virtual, en esta línea, invita a reconsiderar el carácter de la etnografía ligada a unas coordenadas espaciotemporales concretas, porque las "nuevas tecnologías de la interacción" facilitan que las relaciones se desplacen o se sostengan en diferentes espacios y temporalidades. Por lo tanto, propone pensar en "interacciones mediadas" (Hine, 2004, p. 81) que hacen de la etnografía un método más fluido, dinámico y móvil. Precisamente, el "reto" de la etnografía virtual consiste en "examinar cómo se configuran los límites y las conexiones, especialmente, entre lo 'virtual' y lo 'real'" (Hine 2004, p. 81).

En este marco, se construyó un corpus heterogéneo de materialidades para acercarse a la recepción de los dos libros que se han estado analizando. En primera instancia, la literatura juvenil contemporánea de circulación masiva no es reconocida como una literatura válida de ser reseñada y/o analizada por la crítica y las revistas literarias. Estos libros, en tanto inscriptos en esa producción, no han circulado por esos lugares especializados del campo literario. No obstante, no son estos los únicos espacios por donde un libro puede ser mediatizado. Por ese motivo, este análisis incluye los medios de comunicación, los blogs y canales de YouTube que administran jóvenes lectores, los comentarios que en ellos dejan sus seguidores y los comentarios en la plataforma Goodreads.

S.O.S. Tengo mi primera cita fue reseñado en dos medios de comunicación diferentes entre sí. Uno es la agencia de noticias estatal TELAM y el otro la revista juvenil TKM. En el primero se publica una entrevista a la autora en la sección "Cultura", en donde se destaca el lugar en el campo que construye para sí misma y la publicación al manifestar un vacío editorial en el tratamiento de temas para preadolescentes y adolescentes: "Veo desinformación y hay pocos libros o publicaciones que los guíen en esta etapa de tantos cambios, donde dan sus primeros pasos en el amor" (Télam, 2014, s/p). En este sentido, ubica su libro en un lugar del campo que pareciera no estar explorado y lo plantea como una novedad. Sopesando esta construcción de la autora, quien escribe la nota (no está firmada), asegura que es un libro "al mejor estilo revista femenina", encontrando una continuidad de este tipo de literatura con otros discursos (tal como se explicó en el apartado anterior).

Por su parte, la revista TKM recomienda la lectura de este libro en su sección "Libros y Cómics" para que la lectora se "relaje, divierta y aprenda cómo lidiar con la situación" (TKM, 2016, s/p). Esta recomendación reproduce el resumen que el libro tiene en su contratapa e invita a leerlo en la plataforma Leamos, de suscripción mensual paga para descargar e-books. Se aprecia, aquí, que no circular por los espacios propiamente literarios le posibilita inscribirse en aquellos otros en donde transitan sus potenciales lectores. Diario de una ruptura -en cambio- no tuvo reseñas o comentarios en medios de comunicación tradicionales, sino que todas sus referencias están en otros espacios de circulación más diversos.

A su vez, en cuanto a las reseñas y comentarios que realizaron los lectores en un conjunto de plataformas digitales: blogs, YouTube y Goodreads, estos géneros discursivos no pueden compararse con una reseña en una revista literaria, porque su estilo y composición son diferentes, tienen un registro informal y coloquial. Tampoco con las reseñas o recomendaciones de los medios de comunicación, ya que estas nuevas narraciones se escriben/dicen en primera persona, construyendo una vOz más subjetiva e íntima. Así, no solo narran el contenido del libro, sino también qué les sucedió cuando lo leyeron.

Por otro lado, un aspecto que se tematiza en estas textualidades es la edición: cuando el libro está editado en papel, se comenta su diseño, tamaño y materiales como una dimensión más de análisis. Por último, es importante mencionar que el mayor porcentaje de jóvenes que reseñaron estos libros los obtuvieron como obsequio por parte de la editorial 
o la escritora y en algunos casos, se destaca la relación que tenían con ella por su trabajo en la editorial. Se aprecia, entonces, una búsqueda e interés particular para que los libros circulen por estos nuevos espacios de legitimación entre jóvenes: ya no son los padres, los profesores, los bibliotecarios quienes recomiendan lecturas, sino sus propios pares.

Reconstruyendo los sentidos y las sensaciones (Littau, 2008), es decir, atendiendo no solo a su comprensión, sino también a lo que como lectores sintieron al leer los libros, se encontraron tres maneras de apropiarse de S.O.S. Tengo mi primera cita y Diario de una ruptura. La primera está vinculada con el entrenamiento y la fluidez en la lectura. Ambos libros tienen entre 80 y 100 páginas, y se destaca que la escritura amena y fluida posibilita que puedan leerse en pocas horas e-incluso- de manera colectiva, con amigos.

Se ve -asimismo- como una opción "corta" y "liviana" para leer entre otras lecturas más largas y densas o para salir de un "bloqueo lector". Esta sensación puede -en algunos casos- derivar en que se consideren estos libros como "básicos", "muy breves" o "sin desarrollo de lo que le pasa a los personajes". Respecto del primero, se coincide en decir que es un libro para "divertirse", "distraerse un rato" y "reírse" (Comentarios de lectores publicados en la plataforma Goodreads. Extraído de: https: //www. goodreads.com/book/show/22918110-s-o-s-tengomi-primera-cita, última fecha de consulta: 9 de febrero de 2018).

Del segundo que, como no recurre a la melancolía para hablar de la ruptura de una relación eróticoamorosa, es "entretenido" y sirve para "verle el lado bueno a las cosas" e incluso poder reírse de algunas situaciones vividas por los personajes, sobre todo la relación que tiene Brenda con su abuela. (Comentarios de lectores publicados en la plataforma Goodreads. Extraído de: https: //www.goodreads. com/book/show/28948427-diario-de-una-ruptura, última fecha de consulta: 9 de febrero de 2018).

En palabras de los lectores:

La verdad que [S.O.S Tengo mi primera cita] es un libro sumamente divertido, me he reí- do mucho con las experiencias y anécdotas que nos cuenta la autora.

Clara (blog Fantaseando con libros, extraído de: http: //fantastacioconlibros.blogspot. com.ar/2014/09/resena-sos-tengo-mi-primera-cita.html última fecha de consulta: 9 de febrero de 2018).

Diario de una Ruptura es una lectura breve y dinámica que seguramente te será de gran ayuda para superar un corazón roto o una entretenida lectura para pasar un momento agradable con una historia reflexiva y divertida. Ideal para regalar y regalarse (Stefany, Blog Mi reflejo en el papel, extraído de: http: //fantastacioconlibros.blogspot.com. ar/2014/09/resena-sos-tengo-mi-primeracita.html, última fecha de consulta: 9 de febrero de 2018).

La segunda se refiere a la identificación que sintieron cuando leían, porque se acordaron de experiencias vividas en primeras citas o estaban viviendo en el momento de la lectura una ruptura y leyeron el libro como una guía. Este tipo de apropiación es una de las más estudiadas, en tanto la relación de la lectura con algunos grupos sociales como los sectores populares, las mujeres y los jóvenes, y ha sido nombrada en términos de identificación en estudios anteriores (Viala y Molinié, 1993 y Sapiro, 2011 en Sapiro, 2016). En este contexto, es posible decir que se brinda un marco interpretativo del funcionamiento del mundo social, porque se vincula la experiencia de vida con representaciones sociales interiorizadas por el lector (Sapiro, 2016):

Todas las situaciones que se plantean, desde la previa a la cita, hasta los pensamientos que supuestamente cruzan por nuestra mente, son tal cual a la realidad!!! al menos yo me sentí súper identificada y justamente por eso no podía evitar las risitas que se me escapaban de vez en cuando (Carla, blog Mi mundo está en tus páginas, extraído de: http://mimundoestaentuspaginas.blogspot. com.ar/2014/09/opinion-de-sos-tengo-miprimera-cita.html ${ }_{\alpha}$ última fecha de consulta: 9 de febrero de 2018). 
"Te extraño, te olvido, te amo de nuevo". La construcción del amor en la literatura juvenil argentina

Creo que es un precioso libro [Diario de una ruptura] que cualquier persona en cualquier momento de su vida lo puede leer y sentirse identificado. Me hubiera gustado haber leído algo así cuando me rompieron el corazón o cuando yo misma me lo rompí. Siento que en mi vida, lo voy a releer varias veces (Belén, Goodreads, extraído de: https://www.goodreads.com/ book/show/28948427-diario-de-una-ruptura, última fecha de consulta: 9 de febrero de 2018).

La última forma de apropiación de este libro se relaciona con su función didáctica, es decir, su condición de "dejar enseñanzas" y la posibilidad que se tiene de "reflexionar" y "aprender" no solo qué hacer en una primera cita o cómo superar la ruptura de una relación erótico-amorosa, sino también a valorarse a sí mismo. En este sentido, se asocia la lectura con su dimensión placentera, como en las anteriores apropiaciones y también con su posibilidad de aprendizaje y acompañamiento en determinados momentos de la trayectoria de vida. Incluso ese aprendizaje puede extenderse más allá de los adolescentes a quienes están dirigidos los textos y pueden también sus madres "aprender" cómo se vive la adolescencia y saber qué le pasa a sus hijos.

[S.O.S Tengo mi primera cita] Es un libro que tienen que leer madres e hijas; una para aprender de cómo se dan en actualidad las cosas, otra para comprender que no todo tiene que ser como lo dicen las normas implícitas de esa edad. Sirve para actualizarte, para aprender iy para divertirte! (Florencia, blog Plausible, extraído de: http: //xylobrytes.blogspot.com.ar/2014/10/fotoresena-sos-tengo-mi-primera-cita.html, última fecha de consulta: 9 de febrero de 2018).

Este libro me gustó mucho ya que me encontraba pasando por una ruptura, y a veces me disponía a hacer lo que el libro decía de hecho la lista de canciones y de películas fue la mejor parte, Luis, Goodreads, extraído de: https://www.goodreads.com/book/ show/28948427-diario-de-una-ruptura, última fecha de consulta: 9 de febrero de 2018).

Ideal no solo para los que acaban de terminar una relación de pareja. Cualquiera sea la relación que se te acaba de terminar (de pareja, de amigos, creo que incluso sirve si te despidieron de tu trabajo) este libro es ideal para sobrellevar el tiempo de 'duelo' (Natalia, Goodreads, extraído de: https: //www. goodreads.com/book/show/28948427-diario-de-una-ruptura, última fecha de consulta: 9 de febrero de 2018).

\section{A MODO DE CIERRE}

Este trabajo partió de suspender el juicio estético en torno a los dos libros seleccionados para centrarse en un juicio analítico. En este marco, los libros se abordaron en tanto hechos sociales inscriptos en un campo específico y aún más en un contexto socio-histórico que los hace posibles. Asimismo, se afirma que el análisis de objetos literarios debe involucrar perspectivas que trasciendan la indagación textualista o biográfica, porque se entiende que la literatura no es una práctica individual o aislada, así como tampoco los autores son totalmente libres e innovadores. Hay -en cambio- una regulación de lo dicho: hay condiciones de posibilidad que habilitan lo que se dice y lo que no se dice. Para ello, tal como se hizo a lo largo del trabajo, es necesario reconocer las mediaciones presentes entre los libros y el entramado social. Esto significa tener en cuenta las condiciones sociales de su producción, la puesta en forma de las obras y la circulación y apropiación que de ellas se hacen.

Considerando estas dimensiones es posible sostener -entonces- que los géneros literarios son contextualmente variables y no pueden pensarse por fuera de sus condiciones de posibilidad. ¿La muerte en Venecia, de Thomas Mann, que construye a un escritor alemán enamorado de un joven polaco, podría haber sido considerada una novela romántica al momento de su publicación? ¿Romeo y Julieta, de William Shakespeare, convertida en un hito de la literatura romántica, hubiera sido clasificada dentro de ese género si los personajes, en lugar de suicidarse, hubiesen aceptado no estar juntos? ¿El discurso 
de la autoayuda como parte del género romántico hubiese sido aceptado en tiempos donde la narrativa hegemónica construía un "nosotros" antes que un "yo"?

Ligado a esta inquietud, la emergencia de la matriz del amor contingente y su conflictiva copresencia con la matriz del amor romántico en las novelas que tematizan el amor se inscribe en un contexto que hace posible su enunciación. Es decir, en unas coordenadas históricas donde existen leyes que reconocen los derechos de las mujeres, así como leyes de matrimonio igualitario e identidad de género, crean un clima de mayor respeto y reconocimiento a la diversidad sexual y de género.

Siguiendo lo que propone Illouz (2016 [2011], p. 15), acercarse a las narrativas del amor permite acercarse, a su vez, a "los modos de institucionalización del yo y la identidad en la época moderna". En otras palabras, es un microcosmos privilegiado para entender los procesos del tiempo actual. Asimismo, el sufrimiento amoroso habla de la "desregulación del mercado matrimonial, las transformaciones en la arquitectura de la elección de pareja [y] la importancia del capital del amor en la construcción social de un sentido de valor propio" (Illouz, (2016 [2011], p. 29). Analizar, entonces, objetos literarios desde esta perspectiva ayuda a hacerse preguntas que desbordan los límites del texto, observar el estado del campo y acercarse a las representaciones del entramado social de una época.

\section{REFERENCIAS BIBLIOGRÁFICAS}

Altamirano, C. y Sarlo, B. (1993 [1983]). Literatura/ Sociedad. Buenos Aires: Edicial.

Arnoux, E. (2006). Análisis del discurso: tres modos de abordar materiales de archivo. Buenos Aires: Santiago Arcos.

Arnoux, E. (2008). La inscripción en los relatos modernos en la matriz latinoamericanista. En: El discurso latinoamericanista de Hugo Chávez. Buenos Aires: Biblos.

Badiou, A. (2011). Elogio del amor. Madrid: Esfera de los Libros.
Bajtín, M. (1982). El problema de los géneros discursivos. En: Estética de la creación verbal. México: Siglo XXI.

Bourdieu, P. (2015 [1992]). Las reglas del arte. Génesis y estructura del campo literario. Barcelona: Anagrama.

Cámara Argentina del Libro. (2017). Informe de Producción del Libro Argentino Primer semestre de 2017 [en línea]. Recuperado de https:// issuu.com/camaradellibro/docs/informe_de_ producci_n_del_libro_ar_14f17973019e20.

Cámara Argentina del Libro. (2017). Informe de Producción del Libro Argentino 2016 [en línea]. Recuperado de https://issuu.com/camaradellibro/ docs/informe_de_producci_n_anual_2016_v.

Cámara Argentina del Libro. (2016). Informe de Producción del Libro Argentino 2015 - Resumen Ejecutivo. [en línea]. Recuperado de https:// issuu.com/camaradellibro/docs/2016.03.28_informe_de_producci_n_a.

Cámara Argentina de Publicaciones. (2015). Libro blanco de la industria editorial argentina. Informe de datos estadísticos. [en línea]. Recuperado de http://www.publicaciones.org.ar/Libro $\% 20$ blanco.pdf.

Di Stefano, M. (2015). La noción de discurso y de comunidad discursiva. En: Anarquismo de la Argentina. Una comunidad discursiva. Buenos Aires: Cabiria.

Dritsos, G. (2014). S.O.S. Tengo mi primera cita. Buenos Aires: V\&R Editoras.

Dritsos, G. (2016). Diario de una ruptura. Buenos Aires: V\&R Editoras.

Esteban, M. L. (2011). Crítica del pensamiento amoroso. Barcelona: Belaterra.

Fernández, A. M. (1993). La mujer de la ilusión. Pactos y contratos entre hombres y mujeres. Buenos Aires: Paidós.

Giddens, A. (1998 [1992]). La transformación de la intimidad. Sexualidad, amor y erotismo en las 
"Te extraño, te olvido, te amo de nuevo". La construcción del amor en la literatura juvenil argentina

sociedades modernas. Madrid: Ediciones Cátedra.

Hine, C. (2004). Etnografía virtual. Barcelona: Editorial UOC.

Illouz, E. (2016 [2011]). Por qué duele el amor. Una explicación sociológica. Buenos Aires: Katz Editores y Capital Intelectual.

Illouz, E. (2014). Erotismo de autoayuda. Cincuenta sombras de Grey y el nuevo orden romántico. Buenos Aires: Katz Editores y Capital Intelectual.

Illouz, E. (2010). La salvación del alma moderna. Terapia, emociones y la cultura de la autoayuda. Buenos Aires: Katz Editores y Capital Intelectual.

Littau, K. (2008). Teorías de la lectura. Libros, cuerpos y bibliomanía. Buenos Aires: Manantial.

Papalini, V. (2015). Garantías de felicidad. Estudios sobre los libros de autoayuda. Buenos Aires: Adriana Hidalgo Editora.

Sapiro, G. (2016). La sociología de la literatura. Buenos Aires: FCE.

Telam. (2014). Una guía para chicas sobre la primera cita con varones [en línea]. Recuperado de http://www.telam.com.ar/notas/201409/78061una-guia-para-chicas-sobre-la-primeracita-con-varones.html, última fecha de consulta: 9 de febrero de 2018.

TKM. (2016). Recomendado: S.O.S. ¡Tengo mi primera cita! [en línea] Recuperado de https://www. mundotkm.com/ar/libros-y-comics/707701/ recomendado-s-o-s-tengo-mi-primera-cita, última fecha de consulta: 9 de febrero de 2018. 


\section{Totalitarismo y democracia individualizada: un análisis de La Ola de D. Gansel}

Por: Mag. Aleixandre B. Duche-Pérez ${ }^{1}$, Universidad Católica de Santa María, Perú; Máster Rogelio Scott-Insúa², Universidad de California, San Davis, EE.UU.; Mag. José Carlos Salinas-Valdivia ${ }^{3}$, Universidad de Washington, EE.UU. y Mag. David Blaz Sialer ${ }^{4}$, Universidad Nacional Federico Villareal, Perú

Recibido: 16 de noviembre, 2017.

Aceptado: 10 de marzo, 2018.

\section{Resumen}

El presente texto muestra que La Ola lleva a la sospecha de que el filme, más que tratar sobre el posible retorno del totalitarismo nazi en pleno siglo XXI, da una alegoría de la consolidación del imaginario democrático-liberal luego de la caída del muro de Berlín, del fin de la historia y la muerte de las ideologías.

\section{Abstract}

\section{Totalitarianism and individualized democracy: An analysis of "Die Welle" by D. Gansel}

This study shows that The Wave, rathet than addressing the return of Nazi totalitarism in the mid-21st century, it gives us an allegory of the consolidation of the liberal-democratic imaginary after the fall of the Berlin Wall, the end of history, and the death of ideologies.

1 Aleixandre Duche, es antropólogo, graduado de la Universidad Nacional San Agustín de Arequipa, Perú. En esa misma casa de estudios obtuvo su Maestría en Artes, y en la Pontificia Universidad Católica del Perú, hizo su Maestría en Antropología y cursa el doctorado en Administración Estratégica de Empresas. Es docente tiempo completo en la Universidad Católica de Santa María. Contacto: aduche@ucsm.edu.pe.

2 Rogelio Scott Insúa estudió Psicología en la Universidad Nacional de San Agustín, Perú. Además, es Máster en Antropología Médica y Global por la Universitat Rovira i Virgili, Tarragona, Cataluña, España y estudiante del doctorado en antropología y psicología médica en la Universidad de California en San Davis, Estados Unidos. Contacto: rscotti@gmail.com.

3 José Salinas Valdivia estudió Literatura en la Universidad Nacional de San Agustín, Perú. Actualmente se encuentra cursando el doctorado en Literatura en la Universidad de Washington. Contacto: jcsalinasvaldivia@gmail.com.

4 David Blaz Sialer, es antropólogo por la Universidad Nacional Federico Villarreal, Perú y Magíster en Estudios Culturales por la Pontificia Universidad Católica del Perú. Contacto: diblazsialer@hotmail.com.
Aleixandre B. Duche-Pérez, Rogelio ScottInsúa, José Carlos Salinas-Valdivia y Mag. David Blaz Sialer Totalitarismo y democracia individualizada: un análisis de La Ola de D. Gansel. Revista Comunicación. Año 39, volumen 27, número 1, enero a junio, 2018. Instituto Tecnológico de Costa Rica. ISSN: 0379-3974 / e-ISSN1659-3820.

\section{PALABRAS CLAVE:}

Totalitarismo, cine, La Ola, psicologización, perversión, posmodernidad, democracia.

\section{KEY WORDS:}

Totalitarianism, cinema, The Wave, psychologization, perversion, posmodernity, democracy. 


\section{INTRODUCCIÓN}

Una de las características actuales de películas históricas recae en que su búsqueda de realismo y coherencia parece haber encontrado en la narrativa psicológica un aliado perfecto (Hontoria y Berenguer, 2013; Gregori, 2015). Así por ejemplo, La Caída muestra los últimos días del III Reich ya no desde la épica de las trincheras y los campos de batallas, sino desde la cotidianeidad de la vida de los altos mandos nazis, sobre todo Adolf Hitler. En ella se ve a un Hitler apasionado, dividido, rabioso, un Hitler y una segunda guerra mundial reinterpretada y ambos "aclarados" desde las pasiones y personalidad de sus líderes. Este nuevo recurso está inscrito desde una época como la actual, donde la psicología y lo "psicológico" han adquirido un lugar preferencial en las producciones de ficción y las interpretaciones del pasado, respondiendo a su vez a una "demanda" de verdad psicológica por parte del público (Imhof, 2017). Es decir, lo psicológico se ha convertido en uno de los recursos principales para responder a la demanda de realismo y coherencia narrativa, inclusive causal. Vale la pena destacar que se llama psicologización al proceso por el cual las ciencias psicológicas producen la expectativa de la localización de la verdad del lado del fuero privado e íntimo de los sujetos, tanto como tecnología social, como figura narrativa.

La Ola [Die Welle] (Gansel, 2008) es una película alemana que se sirve de los recursos de la psicología y la interioridad para presentar una historia acerca del totalitarismo latente que anida en sujetos democráticos. Los medios en general han brindado buenas críticas a la película y enfatizado particularmente sus potenciales pedagógicos y cívicos. Lo que se sostendrá aquí será lo contrario. La Ola falla como texto ético al suturar el núcleo problemático de su propia textualidad. Asimismo, fracasa como texto moral al prescribir una fábula que no solo sutura, sino que además prescribe una narrativa distinta a la tensión axiológica propuesta en el mismo filme (Aertsen, 2017).

\section{MÉTODO Y ANÁLISIS}

La aproximación que se hará hacia la película no se basa en su cotejamiento con los hechos reales ni su semejanza con la realidad que erróneamente estaría obligada a re-producir. Si a pesar de esta aclaración se opta por presentar un análisis fuera de lo estético, es porque se cree que, debido a que el cine es más que una mera re-presentación de la realidad, lo es precisamente porque este constituye una interpretación de esta (Cohen, 2006). Como afirma Ubilluz (2009, p. 66), el cine (en tanto arte) y el mundo objetivo "habitan la misma esfera del lenguaje. Quiéralo o no, el arte incide -niega, cuestiona, suspende o valida- la constitución de nuestro horizonte-de-lenguaje, de nuestro mundo-objetivode-lenguaje". En otras palabras, el arte habita en el mundo del sentido y del lenguaje, y se sirve de él -de sus elementos, sus símbolos y sus mitos- para reordenarlo y presentar una creación nueva.

Si se decide realizar un análisis desde el punto de vista psicoanalítico de la cultura, es porque a pesar de no existir indicio ni garantía alguna de un sentido trascendental del texto, no obstante, este se encuentra en un universo de sentido y es capaz de anclarse en ciertas coordenadas de verdad en una época determinada. En decir, siguiendo al novelista Oz (2004), se sostiene que existen dos formas de "lectura" y de lectores: por un lado se encuentra el "mal lector", aquel que busca la última palabra del relato, que pretende encontrar en el texto las razones íntimas del autor, su biografía profunda y reducir la riqueza del texto a arquetipos equivalentes e intercambiables; en suma, aquel que presupone una verdad que se encuentra entre el autor y la obra. En contraste con el "mal lector", Oz plantea la posibilidad de uno "bueno", que busca el corazón del relato entre la obra y el lector, aquel que -parafraseando a Barthes- le pueda dar muerte al Autor.

Así, al desplazar el punto de tensión del autor al lector, la obra pasa a ser algo potencialmente distinto a una mera metáfora biográfica y simultáneamente se mantiene libre de ser reducida a una creación ahistórica. Por el contrario, pensando fenomenológicamente, la obra solo existe-en-la-lectura y el universo socio-simbólico en el que la lectura está siendo ejecutada. De esta manera, una obra nunca existe fuera del Otro, es decir, fuera de las coordenadas axiológicas y axiomáticas que le confieren un sentido. Por lo tanto, obra e interpretación son las dos facetas de un mismo proceso (Izod, 2000). Es por 
eso que se propone un análisis de la obra basado en sus propias disposiciones narrativas y textuales, pero a la vez tomando en cuenta el hecho de que ya se encuentra inscrita en una interpretación en sintonía con la época.

En ese sentido particular, ha existido un consenso tácito en los críticos y la opinión pública en general al interpretar La Ola como una historia capaz de interpelar al imaginario democrático contemporáneo (Neumann, 2013) y plantear a través de su historia una natural y ominosa contigüidad entre democracia y totalitarismo (Penarik, 2015). Este totalitarismo inminente en juego sería el "otro lado" de la democracia, el suplemento obsceno capaz de emerger a partir del malestar en ella (Arendt, 2004). No es de sorprender entonces que la película haya recibido elogios en medios tan dispares como la prensa cristiana y los portales de "contrainformación" de izquierda.

Nieto \& Aleixandre (2009) resaltan la capacidad de interpelación moral del filme, aunque también Ilegan a conclusiones diversas, inclusive opuestas: si para unos La Ola advierte de los riesgos de la debilidad moral de la juventud contemporánea (Neumann, 2013), para otros consiste en la puesta en evidencia del núcleo totalitario de la sociedad de mercado (Penarik, 2015). Lo que tienen en común todas estas interpretaciones es el reconocimiento de las grietas que la película abre en la narrativa democrática del siglo XXI y el cierre interpretativo que le confiere el estatuto de un texto moral.

\section{PONIÉNDOSE EN CONTEXTO: LA OLA [DIE WELLE] DE GANSEL}

La obra toma lugar en una escuela secundaria de la Alemania actual. La escuela programa una Semana de Proyectos orientada a "presentar a los alumnos las ventajas de la democracia", la cual consiste en unos seminarios electivos acerca de distintas formas de gobierno, entre ellas la autocracia.

Rainer Wenger, maestro de educación física y política, es parte del equipo docente que conducirá la Semana de Proyectos. Como ex-okupa y anarkopunk berlinés, Rainer se encuentra naturalmente identificado con el curso de anarquía, uno de los sistemas políticos disponibles. Desafortunadamente, otro docente toma el curso y Rainer queda derivado al curso de autocracia.

Resignado, Ileva el curso de autocracia luego de un fallido intento de negociación. Al inicio del curso se encuentra con una clase desmotivada y apática. El maestro intenta iniciar la conversación con sus alumnos: "Autocracia procede del griego y significa gobierno de uno mismo. En una autocracia el individuo o el grupo que posee el gobierno tiene tanto poder que puede cambiar las leyes como quiera [...]. ¿Alguien me puede dar un ejemplo?" (Gansel, 2008). Un alumno menciona el ejemplo del Tercer Reich. El resto de la clase reacciona con disgusto: "no quiero volver a machacar lo mismo otra vez. La Alemania nazi fue una mierda, ya me di cuenta. Aquí no puede volver a pasar algo así. No podemos sentirnos continuamente culpables con algo que no hemos hecho" (Gansel, 2008). Los alumnos expresan al unísono su disgusto ante algo que aparentemente ha quedado claro gracias a la educación políticamente sensible recibida durante toda la historia de la Alemania de post-guerra:

-Rainer, ¿no podemos hacer otra cosa? Hablemos del gobierno de Bush -dice un alumno.

-Un momento, a mí me está pareciendo interesante -responde el profesor. Piensan que en Alemania no sería posible que vuelva una dictadura, ¿cierto?

-De ningún modo -responden los alumnos-, ya hemos aprendido la lección (Gansel, 2008).

Rainer ofrece un descanso de diez minutos, que aprovecha para pensar cómo realizar una experiencia aleccionadora para sus alumnos, impermeables a los sermones habituales. Termina diseñando un experimento: en lugar de enseñar acerca de las bondades de la democracia y los peligros de la autocracia, orientará progresivamente la clase a adoptar una organización proto-fascista y exponer a los alumnos a las seducciones del totalitarismo. Establece cambios significativos en la organización de la clase. Exige que todos se dirijan a él por su apellido (Sr. Wenger) y no por su nombre 
de pila. Reorganiza la disposición de los asientos, ahora ordenados en columnas y apuntando hacia la pizarra, y ubica a los estudiantes con calificaciones bajas junto con estudiantes con notas altas, "para que puedan ayudarse". Todo aquel que quiera hablar deberá pedir la palabra y ponerse de pie. A ello Rainer acuña un eslogan: "el poder mediante la disciplina" (Gansel, 2008). Durante las siguientes clases el profesor empieza a enumerar con los alumnos las causas de una dictadura (nacionalismo, insatisfacción, desempleo, etc.).

Rainer retoma el hilo de la conversación y pregunta nuevamente sobre los requisitos indispensables para que exista un régimen autocrático; "todas las dictaduras tienen un líder" (Gansel, 2008) -le responden. La clase acuerda que el Sr. Wenger será su Führer. En las clases siguientes, además de las causas se empieza a indagar sobre las características sociales de un régimen autocrático. Conforme se van mencionando los rasgos del fascismo (uniformidad, simbología, unidad de grupo, colectivismo, anti-individualismo, etc.), la clase va progresivamente implementándolas. Finalmente, terminan formando un movimiento: La Ola.

Es importante detenerse ahí por un momento y notar que, conforme se adoptan gestos y rituales fascistas, el filme plantea que los alumnos están inequívocamente transitando de modo gradual hacia el fascismo. Esta será una asociación recurrente a lo largo de la película; a saber, "para llegar al totalitarismo no será necesaria la suscripción a ciertas ideas totalitarias, sino simplemente la adopción de la estética fascista" (Fuentes, 2014; Martin y Vioulac, 2014). Por eso el proceso culminante de la formación del movimiento de La Ola se da cuando el grupo logra elaborar con efectividad una estética compartida y diferencial (emblemas, saludos, vestimenta, que resemblarían la uniformidad fascista) respecto a las otras subculturas que habitan la escuela (punks, skaters, raperos y otros) y no mediante la suscripción a un ideario común ni por la exaltación de valores típicos del fascismo (algunos de ellos incluso sugeridos como tales al inicio de la película), como el nacionalismo extremo o el odio hacia un grupo externo. Esta última característica -es decir, el odio irracional hacia un grupo externo- resulta quizás una de las características más recordadas y emble- máticas de la Alemania nazi. Sin embargo, esa posibilidad no es planteada en ninguna parte del filme y su ausencia terminará por poner en duda si realmente La Ola fue una reactualización del fascismo y no únicamente la adopción de ciertos elementos estéticos de este. Como se verá más adelante, esta asociación se dará a lo largo de toda la trama y será uno de los puntos débiles de la película cuando la historia empiece a complicarse.

Pero entonces, ¿cómo es que alguien se convierte en un fascista posmoderno?

\section{"¡ES LA PSICOLOGÍA, ESTÚPIDO!” (O CÓMO CONVERTIRSE EN UN FASCISTA)}

Se tiene entonces un primer momento narrativo donde la semejanza entre La Ola y el fascismo se recrea por medio de la adopción de un semblante y un estereotipo: la uniformidad y la consiguiente supresión de la individualidad. Collins (2012) y Silva (2017) sostienen que esta particular interpretación del fascismo - una entre muchas otras- fue la versión oficial de la democracia liberal de post-guerra, la cual enfatizaba el papel de los individuos libres y -en cierta medida- "desidentificados" de los relatos colectivos, como requisitos indispensables para poder insertarse en el quehacer democrático.

Este tropo proviene inicialmente del liberalismo de la post-guerra (Caki, 2017), pero fue ulteriormente vuelto moneda corriente luego de la popularización de experimentos psicológicos que, inspirados en las acciones fascistas y nazis, intentaron recrear en el laboratorio situaciones donde los individuos ordinarios podrían verse envueltos en acciones que anulasen su juicio personal y maximizasen la influencia de la autoridad o la coerción grupal. Quizás el experimento más conocido de esa época fue el desarrollado por Stanley Milgram (Yukselbaba, 2017; Turowetz y Hollander, 2018). En él, un sujeto experimental común y corriente era asignado por un supervisor para ejecutar descargas eléctricas a otra persona (un cómplice del experimentador) como castigo por errores en ejercicios mentales a los que era sometido.

La idea del experimento era explorar en qué medida un sujeto era capaz de rehuir a sus propios juicios 
morales y someterse a la autoridad del científico al propinar descargas cada vez más fuertes, Ilegando incluso a shocks tan altos como de $450 \mathrm{~V}$ (evidentemente las descargas no eran reales). Lo que Stanley Milgram creyó demostrar fue una recreación experimental de la tesis arendtiana de "la banalidad del mal" en sujetos comunes y corrientes, y (aún) no cooptados por la identificación ideológica (Kaposi, 2017; Hollander y Turowetz, 2017). Si una persona ordinaria podía sucumbir tan rápidamente ante las presiones de un científico, la complicidad del pueblo alemán ante un líder carismático y una situación de crisis eran totalmente explicables científicamente. Una vez culminado el experimento, Milgram invitaba individualmente a cada participante y le exponía la naturaleza del experimento y su resultado. Luego exhortaba a su participante a realizar una reflexión moral acerca de lo sucedido.

De Vos (2009) ha elaborado un interesante análisis de los experimentos Milgram desde una perspectiva lacaniana. Según sostiene convincentemente, los momentos finales del experimento -la confesión y la reflexión autocrítica ulterior- no constituían meros detalles anecdóticos de la voluntad humanística de Milgram, sino un elemento clave del experimento y la psicología social de esa época; a saber, su labor pedagógica y su potencial como una ingeniería social efectiva. A partir de esa época se volvió más notoria y agresiva la psicologización que llevaría a cabo el Estado en todos los campos de su jurisdicción social: educación, salud, derecho, seguridad, etc., luego de que estos experimentos de consumo masivo "demostraron" la utilidad pública de la ciencia psicológica.

Si se trae esta viñeta a colación es por dos razones. La primera es por el lugar que ocupa la psicología en ambos procesos, es decir, como un agente (Milgram) y un eje narrativo central (La Ola). Esto no quiere decir - por cierto- que se pretende construir la verdad del texto por medio del "diagnóstico psicológico" de los personajes del filme (Barros, Vinicius y Dantas, 2017), sino que -por el contrariose intenta encontrar cómo la película se estructura como un caso psicológico muy similar-además de Milgram- a experimentos contemporáneos como los de Phillip Zimbardo y su "proyecto Lucifer" (Lurigio, 2009). En otras palabras, en lugar de buscar la psicología de la película, se plantea localizar la psicología en la película.

La segunda razón es para señalar los paralelos existentes entre la forma en que la psicología construye sus regímenes de verdad mediante algunos hitos significativos que sirven de alegoría a su lugar en la sociedad (Haig y Borsboom, 2012; Kaestner, 2015; Glaveanu, 2017) y la forma en que la película plantea una verdad sobre sí misma. Así, resulta evidente que el experimento Milgram y La Ola pueden ser leídos -en cierta medida- como experimentos "gemelos", sobre todo si se toma en cuenta que el caso de la vida real que inspiró la película también tomó lugar en la década de 1960 durante una clase de historia contemporánea sobre el Holocausto.

A decir verdad, la película de Dennis Cansell es una entre muchas adaptaciones artísticas de un hecho de la vida real. En 1967 un profesor de historia contemporánea de una secundaria de California decidió aplicar un experimento a sus alumnos para demostrarles, ante su estupor frente a la ignorancia (y consentimiento) que el alemán promedio ejerció durante el holocausto, cómo inclusive ellos -futuros ciudadanos de una sociedad democrática- serían capaces de sucumbir ante las seducciones totalitarias del fascismo. El experimento (denominado La Tercera Ola) consistió en la fundación de un movimiento con claras posturas totalitarias (similares a las del fascismo), tanto en la cohesión interna como en la agresividad hacia los exogrupos y sobre todo, en la supresión de los juicios individuales por sobre los colectivos. Al finalizar el experimento, se había formado un movimiento consistente y el profesor optó por revelar que La Tercera Ola era un invento y que fueron parte de un experimento para demostrar por qué los alemanes no pudieron ni quisieron denunciar el holocausto. En 1981, la cadena ABC produjo una película para la televisión. Asimismo, existen libros, documentales y hasta obras de teatro inspiradas en los hechos.

Deesta manera, la "verdad psicológica" seplantea en ambos casos como un doble pliegue. Primeramente, existe la verdad tecnológica de la psicología, es decir, aquella que se evidencia mediante la alteración fehaciente del comportamiento externo (en el caso de La Ola, la alteración total de la conducta y el 
semblante de los alumnos y, en el caso de Milgram, en la "obediencia totalitaria" de los participantes a las órdenes del científico). El segundo momento de la verdad psicológica consiste en la verdad confesional de la psicología, es decir, cuando se moviliza una comunicación reflexiva y autocrítica del estado interior de la persona acerca de su propia conducta (el ritual de confesión-reflexión en el experimento Milgram, el "malestar subjetivo" en los personajes de La Ola, además de los testimonios que elaboran una vez terminada la semana de proyectos en la escuela).

En este sentido preciso, la psicología funciona, en los términos de Lacan (1992), bajo los lineamientos del discurso universitario. En otras palabras, se trata de un discurso donde el saber (científico, tecnológico) es Amo (psicólogo) y pretende domesticar o controlar un exceso (el totalitarismo potencial en cada uno de las personas) para luego dejar como producto un sujeto "dividido" (el participante del experimento que se topa con sus propios actos monstruosos a pesar de sus valores morales).

Si La Ola y la psicología social resultan experimentos gemelos, es porque precisamente están organizados bajo coordenadas discursivas análogas y por discurso no se refiere únicamente a "una manera de decir las cosas", sino a una disposición específica de la Verdad y el Sujeto (Horne, 2007). El filme, por fines narrativos, enfatiza entonces las tensiones y separaciones entre el ámbito de lo personal y el ámbito de lo colectivo.

Al transmitir las escenas "privadas", fuera del dominio de la escuela, la película enfatiza en exponer a los alumnos como conducidos por una vida de "excesos" (fiestas, alcohol, drogas, etc.), pero también con carencias y falta de sustancia (soledad, frustración, crisis de identidad). Este planteamiento se constituye en la narración como el caldo de cultivo perfecto desde donde podría anidar una seducción y una satisfacción con el fascismo (Fabbri, 2015).

Si bien la figura de la personalidad débil es una muletilla muy común tanto en el cine como en la psicología pop, no obstante es quizás en las películas actuales sobre nazis donde se ha explotado mejor esta tensión. Por ejemplo, en Der Untergang
[La Caída], se muestra a un Hitler frustrado, dividido e impotente durante los últimos años del III Reich. Igualmente, en Inglourious Basterds [Bastardos sin gloria], Quentin Tarantino retrata a unos nazis acomplejados e inseguros. En La Ola, el vacío de la vida íntima será lo que sintonizará con las seducciones del fascismo.

En ese sentido, si -según los propios diálogos al comienzo de la película- los alumnos inicialmente planteaban que la autocracia era producto de la crisis social y económica, en la pandilla de La Ola -por el contrario- su "fascismo" era producto de una crisis personal y hasta cierto punto, una crisis de adolescencia. No se está sugiriendo que el filme proponga reinterpretar los hechos de la historia en clichés psicológicos vulgares ("los nazis tenían complejos de inferioridad frente a los judíos", "Hitler tuvo problemas en la infancia"), sino cómo ignora la crítica al malestar en la democracia y el goce contemporáneos que la película misma había elaborado (un malestar con la misma democracia que los alumnos debían valorar) y lo sustituye argumentativamente por una progresiva sincronización entre el fuero privado y el ámbito público (Eder, 2006; Gibbs, 2017). Es así que, por ejemplo, al final de la historia, Tim termina organizando un pequeño tiroteo que culmina en su suicidio, haciendo notar que su acto fue un hecho de locura latente generada por su soledad e incomprensión, pero activada por el totalitarismo de La Ola. De esta manera, todos los personajes principales, incluido el profesor Rainer, ven La Ola como el medio para y el producto del desahogo de las frustraciones individuales y privadas.

En este punto se llega a un atolladero: ¿Si La Ola se erige en la crítica como un texto moral y una fábula, entonces cómo es que explica el fenómeno totalitario? Es decir, ¿si La Ola es un texto moral, cómo plantea su moraleja?

\section{LA DEMOCRACIA INDIVIDUALIZADA (O "LO SOCIAL ES MALO PARA TI")}

En el apartado anterior se dijo que el filme expone su propia interpretación en las transiciones narrativas que van del fuero individual y privado (presuntamente) "democrático" al ámbito público 
y colectivo (presuntamente) "totalitario". En esta sección se explorará con mayor detalle este tránsito para luego intentar recortar y elaborar, como sostiene Gaut (2010), el cierre moral que se plantea al final de la historia e interpela por igual a críticos conservadores y progresistas.

El punto de partida son entonces las figuras del exceso y el vacío existencial. En una de las primeras escenas, los jóvenes de la escuela están bebiendo y bailando desenfrenadamente en una fiesta. En ella Marco discute con su amigo Martin:

-Martin, dime una cosa, ¿contra qué debe una persona rebelarse hoy en día? De todos modos ya nada tiene sentido. La gente ahora sólo piensa en su propio placer. Lo que le falta a nuestra generación es una meta conjunta que nos una.

-Son los tiempos que vivimos. Mira a tu alrededor, ¿quién es la persona más buscada en internet? La maldita Paris Hilton... (Gansel, 2008).

Obviamente este diálogo catapulta el anhelo por una causa común y colectiva, ya que los motivos para rebelarse se han agotado. Unión y rebelión son asociados entonces como intercambiables (Herrero, 2016). Pero además, se tiene en la misma escena el contraste entre el desenfreno anómico y "atomizado" de los jóvenes y a Marco interrogándose por su generación. Por lo tanto que los miembros de su generación no estén unidos no implica únicamente que carezcan de utopías o grandes narrativas, sino que fundamentalmente se encuentran solos. $Y$ es esta soledad la que precisamente interpela a la misma narrativa democrática presente en el texto fílmico.

Si la democracia se encuentra fundamentalmente anidada en el fuero privado (ya que como se observa en el filme, el peligro totalitario proviene del ámbito colectivo y público) y si esa pax democrática privada solo se puede mantener con individuos aislados (Fay, 2018), esto quiere decir que la democracia falló en su proyecto de crear un mejor lazo social entre los hombres, por el sencillo hecho de haberse diluido el lazo social sustancial entre ellos. En otras palabras, si se lleva hasta el final la inter- pretación que desde esta escena se hace de todo el filme, la conclusión a la que se llega es que si en la Alemania actual (de la película) aún no se ha "regresado" a la autocracia no es por la presencia de un lazo social cualitativamente superior, sino por la virtual desaparición de vínculos sociales (Kapczynski, 2015; Rulinskiy, 2016). Es de este modo que la misma pregunta de Marco puede ser el hilo conductor de la trama de la película en todos los ámbitos en que se consolida y se exponen los vínculos de La Ola.

En otra secuencia, se ve al equipo de waterpolo (que el mismo Rainer entrena) incapaz de conseguir una victoria a causa del individualismo de cada uno de sus competidores. Luego de la primera sesión del experimento, Marco y Sinan -otrora rivales en su mismo equipo- acuerdan pasarse el balón para anotar un gol durante un entrenamiento y lo consiguen. Es entonces cuando los jóvenes empiezan a apreciar los beneficios del "poder mediante la disciplina" (Wolf, 2018), aprendido gracias a Rainer y La Ola, y cuando sus vidas empiezan a cambiar. Los antiguos enemigos comienzan a amistarse y trabajar juntos (es destacable la escena donde Marco y Sinan, antiguos oponentes, festejan juntos antes de un partido decisivo de waterpolo contra una escuela rival), quienes antes eran solitarios inician a formar lazos de amistad y protección (como la escena en que el ermitaño Tim es defendido por sus nuevos amigos en una discusión con unos punks) y los egoístas empiezan a ceder para actuar solidariamente.

Es en este punto en que el andamiaje del filme se tambalea, ya que es precisamente la idea sostenida a lo largo de la historia que la aprehensión del fascismo se da por medio de la adopción de la estética fascista (Borkovetz, 2004; Spackman, 2006), sobre todo lo que está relacionado con lo colectivista y lo uniforme) que al final de la película no queda claro si La Ola terminó siendo un grupo fascista stricto sensu o simplemente un grupo subcultural, algo agresivo, pero con todas las características de una subcultura.

Una de las escenas más ambiguas de la película es cuando Rainer -consciente de que La Ola se le fue de las manos- convoca a todos los simpatizantes al 
auditorio con la intención de disolverla y develar a los alumnos en qué se habían convertido. Entonces el maestro empieza a leer los testimonios anónimos de La Ola...

-"Siempre he tenido todo lo que quería: ropa, dinero, etc., pero lo que siempre tenía era aburrimiento, pero estos últimos días han sido muy entretenidos...".

-"Ya no se trata de quién es la más bonita, la mejor o la de más éxito. La Ola nos ha hecho a todos iguales...".

-“La procedencia, la religión y el entorno social ya no tienen ninguna importancia. Todos pertenecemos a un movimiento...".

-"La Ola nos da un nuevo significado, ideales que merece la pena apoyar...".

-"Antes solía golpear a otros, cuando pienso sinceramente sobre ello me parece algo bastante anarquista, es mucho mejor comprometerse con algo...".

-"Si uno puede confiar en los demás conseguiremos más cosas, por eso estoy dispuesto a sacrificarme..." (Gansel, 2008).

Si se presta atención a los testimonios, resulta difícil encontrar un rasgo eminentemente totalitario o fascista. Por el contrario, lo que los testimonios movilizan es una satisfacción inédita con el lazo social y una excursión por las situaciones tensas que cada testimoniante contrasta con su pasado. Es por esto que resulta irónico que en el preciso momento en que Rainer sancionaría a La Ola por su clara vocación autoritaria y segregacionista, se encuentran alumnos testimoniando tener por primera vez "ideales" y deseos de "comprometerse con algo" -en lugar de estar golpeando a los demás-, gente dispuesta a "confiar en los demás" y alumnos para quienes las diferencias culturales y económicas "ya no tienen ninguna importancia". En suma, más que un movimiento fascista, se evidencia -como sostiene Klevan (2014)- un campo mayor donde el lazo social forma una comunidad. Y si este es el momento culminante en que se muestra "la captura ideológica" de los alumnos a partir de la confesión íntima de sus sentimientos, la pregunta por hacerse debería ser: ¿es esto realmente fascismo? Queda demostrado que esta escena es una interpelación a la sanción moral del espectador. No obstante, hay que preguntarse si lo que se sanciona es necesariamente el totalitarismo o el lazo social en sí.

Si esta confusión entre comunidad (lazo social) y fascismo complica inmediatamente la narración, el asunto empeora cuando se ve que La Ola -en su momento de esplendor- logra cohesionarse tranquilamente sin la necesidad de haber elaborado un grupo-objeto externo de odio (como los judíos para los nazis) ni de un ideario o una ideología. Haciendo una clara alegoría a un discurso hitleriano, Rainer empieza a agitar a las masas en medio de aplausos fervorosos. El maestro muestra el totalitarismo de La Ola en todo su exceso cuando pretende llevar hasta el final el éxtasis de la audiencia y en un exacto juego con el fantasma del público, encarna la grieta misma que La Ola abrió en el status quo:

-Estoy muy impresionado de lo que La Ola les ha aportado. Y por eso creo que este proyecto no debe terminar aquí. [...] Desde hace años Alemania va cuesta abajo. Somos los perdedores de la globalización. Los políticos nos quieren hacer creer que para salir de la crisis hay que rendir más. Pero los políticos son solo marionetas de la economía: "la cuota de desempleo está bajando, somos el primer país en exportaciones". Pero la realidad es que los pobres son cada vez más pobres y los ricos más ricos. La única gran amenaza es el terror. Un terror que nosotros mismos hemos creado, mediante la injusticia que permitimos en el mundo. $\mathrm{Y}$ mientras que nosotros poco a poco, pero sin descanso destruimos el planeta, unos cuantos supermillonarios se sientan por ahí y se frotan las manos, se construyen naves espaciales y observan lo que ocurre incluso desde el espacio.

- ¿Es que no se dan cuenta de lo que pretende? ¡Los está manipulando! -interviene un desengañado Marco. 
-No me vas a impedir que diga la verdad, Marco.

- ¡La Ola es el verdadero problema!

-No, La Ola es la única vía para arreglar el camino que están tomando las cosas. Juntos podemos conseguirlo todo. Nosotros hoy tenemos aquí la posibilidad de hacer historia (Gansel, 2008).

Si el lector encuentra increíblemente confuso el discurso de Rainer, es porque abre la posibilidad de un cambio radical luego de exponer el agujero inherente en la democracia neoliberal de la Alemania actual que la Semana de Proyectos debía enaltecer ("los ricos se hacen cada vez más ricos y los pobres más pobres", "hemos creado un terror nosotros mismos", "estamos destruyendo el planeta") (Birgel, 2009; Bilis, 2017). Solo aislando este fragmento se puede apreciar el proceso de sutura ideológica en el que se envuelve la textualidad de la película, ya que -antes que nada- la ambigüedad del sujeto enunciador (no se puede ver claramente si está parodiando un discurso izquierdista alter-globalizador y equiparándolo con el totalitarismo o si está siendo fiel a la grieta abierta en el discurso de la democracia formal expuesta por la experiencia de La Ola) no anticipa el sentido que el resto de la historia tomaría.

En resumen, al escuchar a Rainer pronunciar un discurso que tranquilamente hubiera sido importado de sus años mozos, cuando vivía en una casa okupa berlinesa luchando contra la policía y en solidaridad con algún país del tercer mundo, ahora se encuentra narrativamente teñido de "fascismo". No se puede encontrar un mejor ejemplo de lo que significa en el fin de la historia y la caída de los grandes ideales.

Más que un filme sobre la Alemania nazi, se ve cada vez más que el filme alegoriza la caída del muro de Berlín y las consecuencias civilizatorias que acarreó tal acontecimiento (O'Brien, 2009; Tapper, 2013) al parodiar Rainer un discurso con inmediatas resonancias con una agitación socialista y simultáneamente al descalificarlo al plantearlo como análogo a un caduco discurso nazi (Von Moltke, 2007).
Unos minutos más adelante, se evidencia que efectivamente Rainer se aleja del agujero abierto en el Otro de la democracia, solo para coger vuelo y romper radicalmente con La Ola:

- ¿No se han dado cuenta de lo que ha pasado aquí? [...] ¿No se acuerdan ya de la pregunta que surgió al inicio de la clase: si una dictadura era posible en estos tiempos? Pues es lo que acabamos de ver, fascismo. Todos nos hemos considerado mejores, mejores que los demás. Y lo que es aún peor, hemos excluido de nuestro grupo a todos aquellos que no pensaban igual. Les hemos hecho daño y no quiero pensar de qué más habríamos sido capaces. Les tengo que pedir disculpas. Hemos ido demasiado lejos, yo he ido demasiado lejos. Todo esto se acabó.

- ¿Y qué significa eso para La Ola?

- Que se ha terminado.

- Pero no todo estaba mal en La Ola. Todos lo hemos sentido, hemos cometido errores, pero podemos corregirlo.

- No, Dennis, algo así no se puede corregir. Quiero que todos vayan a casa ahora. Creo que tienen muchas cosas sobre las que reflexionar (Gansel, 2008).

Efectivamente, como dice Rainer, habían ido demasiado lejos, pero no en la dirección aparente. Fueron "demasiado lejos" al no quedarse con el civismo celebratorio de la democracia globalizada que se les asignó como proyecto pedagógico (Bluestone, 2000; Oh, De Gagné y Kang, 2013). Fueron demasiado lejos al procesar el malestar que la sociedad de consumo y la competitividad meritocrática que esta les planteaba. Fueron lejos al transgredir los muros tácitos que convierten a los inmigrantes en ciudadanos de segunda clase dentro de la sociedad europea. Y frente a ese exceso, Rainer retrocede, diciendo además que La Ola en su conjunto es un error insalvable.

Parafraseando a De Vos (2009), Rainer se coloca a sí mismo en una posición meta-humana y asume 
la tarea de ser un mero sirviente de la democracia para -paradójicamente- humillar a sus alumnos. Según el psicoanálisis, la reducción de uno mismo al estatuto de un instrumento del Otro (la ciencia, la democracia, el partido) es estrictamente homóloga a la posición del perverso. Como sostiene Lacan (2007), el perverso ocupa el lugar del objeto para el beneficio de otro, para quien goza sádicamente. Es como si Rainer estuviera diciendo tácitamente: "no es mi deseo ni mi responsabilidad el traer toda esta monstruosidad fascista a la luz, yo sólo soy un instrumento de la democracia" (Gansel, 2008).

El experimento de La Ola, desde el inicio, estuvo programado para llegar al momento del desengaño, del levantamiento del velo para revelar la desnudez de la -supuestamente- verdadera naturaleza (totalitaria) de los alumnos. Para ponerlo en términos sencillos, la lección que brinda el experimento de Rainer es el poder de este, así como la "la cátedra psicológica que nos da [el experimento Milgram] es acerca del poder de la psicología" (De Vos, 2009, p. 237).

El filme culmina mucho antes de la aparición de los créditos finales. Solo se mencionará que luego de la sanción perversa de Rainer, Tim -el alumno más entusiasta para con La Ola- termina suicidándose.

\section{CONCLUSIÓN: “GOODBYE, HITLER”}

Como ya se expuso, un análisis más detallado de La Ola lleva a la sospecha de que el filme, más que tratar sobre el posible retorno del totalitarismo nazi en pleno siglo XXI, hace una alegoría de la consolidación del imaginario democrático-liberal luego de la caída del muro de Berlín, del fin de la historia y la muerte de las ideologías (Hochscherf y Winkel, 2016). El mensaje es medianamente claro: el fascismo estuvo muerto desde la capitulación de 1945. Lo que actualmente peligra es el modelo universal de la democracia neoliberal, que empieza a presentar sus agujeros en la película y en la realidad.

Es importante notar que incluso en los últimos años el pensamiento de extrema derecha en la Europa nórdica ha asimilado un nuevo semblante totalmente alejado del fanatismo étnico y antisemita de antaño. Recuérdese, por ejemplo, a Pim Fortuyn, el candidato holandés de extrema derecha. El clivaje que activaba ya no era un conservadurismo racial y sexual, sino un "choque de civilizaciones" en los que se encomendaba como el defensor de las conquistas civiles y liberales de los países occidentales, incluyendo el hecho de que un gay como él puede darse el lujo de postularse a la presidencia de su país, a diferencia de países teocráticos de Medio Oriente. Se Puede ver que luego de la caída del muro y el antagonismo capitalismo/comunismo, el paradigma del "choque de civilizaciones" ha pasado a convertirse en el framing por antonomasia para pensar las contradicciones del mundo luego del 11 de setiembre de 2001 (Stefanoni 2011).

En su ya repetitiva comparación entre los dos totalitarismos del siglo XX, el fascismo y el stalinismo, Slavoj Zizek -no obstante- deja en claro que ambos son radicalmente distintos. Los aspectos políticos del pasado comunista están borrados y actualmente en los ex-países eurocomunistas se ha erigido una nostalgia vintage acerca de los aspectos idílicos de la vida cotidiana bajo el totalitarismo del partido comunista. Es decir, si bien tanto el nazismo como el stalinismo están prohibidos en la narrativa neoliberal, no lo están de la misma manera: "Aún cuando tenemos plena conciencia de sus aspectos monstruosos, Ostalgie nos parece aceptable" (Zizek, 2004, p. 201). Y como continúa el chiste, Good bye, Lenin nos parece aceptable, pero no Goodbye, Hitler.

¿Dónde se posiciona entonces La Ola? ¿No es la película una versión inversa a la nostalgia vintage, un Goodbye, Hitler? No necesariamente. Si Good bye, Lenin funcionaba como un manifiesto nostálgico de la ingenuidad comunista y el grito de victoria del sistema mundial post-guerra fría (Laucht, 2008), La Ola termina operando como una sutura ante las contradicciones del mundo post-11 de setiembre y la crisis del sistema financiero internacional, es decir, los años posteriores al quebrantamiento del sueño del mundo unipolar. ¿Y la psicología? ¿Si el experimento Milgram pretendió responder perversamente a la "banalidad del mal", creando un Auschwitz psicológico y experimental (De Vos, 2011), no será acaso el experimento de la prisión de Standford una réplica en laboratorio de Abu Ghraib en la era de la guerra contra el terror? 


\section{BIBLIOGRAFÍA}

Aertsen, V. (2017). Sympathy for fictional characters: an examination of the factors involved from a social psychology and cognitive film theory perspective. Doxa Comunicación, 25, 107-128.

Arendt, H. (2004). Los orígenes del totalitarismo. Madrid: Taurus.

Barros, M., Vinicius, M. y Dantas, V. (2017). GestaltTherapy: the question of the subject psychotic in the film "Tideland". Ecos-Estudos Contemporaneos Da Subjetividade, 7(2), 340-348.

Bilis, P. (2017). The cinema of Germany: a historical evaluation of the erratic course of a national film industry. Istanbul Universitesi Iletisim Fakultesi Dergisi, 52, 89-108.

Birgel, F. (2009). Kuhle Wampe, Leftist Cinema, and the Politics of Film Censorship in Weimar Germany. Historical Reflections-Reflexions Historiques, 35(2), 40-62.

Bluestone, C. (2000). Feature films as a teaching tool. Coll Teach., 48, 141-146.

Borkovetz, R. (2004). Did fascist aesthetics win the war? (The National World War II Memorial). Landscape Architecture, 94(9), 14-+.

Caki, C. (2017). Nazism ideology in Turkish cinema: "Kirimli" film and semiotics analysis. Istanbul Journal of Sociological Studies-Sosyoloji Konferanslari, 56, 65-93.

Cohen, J. (2006). Audience identification with media characters. Psychology of Entertainment, 183-197.

Collins, J. (2012). The advent of democracy, vol 3, the test of totalitarism, 1914-1974. New Left Review, 74, 145-154.

De Vos, J. (2009). Now That You Know, How Do You Feel? The Milgram Experiment and Psychologization. Annual Review of Critical Psychology, 7, 223-246.

De Vos, J. (2011). From Milgram to Zimbardo: The Double Bith of Post-War Psychology/Psycholo- gization. History of the Human Sciences, 23(5), 156-175.

Eder, J. (2006). Ways of Being Close to Characters. Film Studies, 8, 68-80.

Fabbri, L. (2015). Neorealism as ideology: Bazin, Deleuze, and the avoidance of fascism. Italianist, 35(2), 182-201.

Fay, J. (2018). Democratic Film and the Aesthetics of Choice. German Life and Letters, 71(2), 169192.

Fuentes, F. (2014). Totalitarism a glance from the 21 st century. Revista de Occidente, 400, 5-6.

Gaut, B. (2010). Empathy and Identification in Cinema. Film and the Emotions, 34, 136-157.

Gibbs, A. (2017). 'What Makes My Image of Him into an Image of Him?': Philosophers on Film and the Question of Educational Meaning. Journal of Philosophy of Education, 51(1), 267-280.

Glaveanu, V. (2017). Psychology in the Post-Truth Era. Europes Journal of Psychology, 13(3), 375377.

Haig, B. \& Borsboom, D. (2012). Truth, science, and psychology. Theory \& Psychology, 22(3), 272289.

Herrero, M. (2016). Religion and the Political: The Answer of Hegel's Philosophy between Tension and Reconciliation. Pensamiento, 72(271), 279294.

Hochscherf, T. y Winkel, R. (2016). Third Reich Cinema and Film Theory. Historical Journal of Film Radio and Television, 36(2), 190-213.

Hollander, M. y Turowetz, J. (2017). Normalizing trust: Participants' immediately post-hoc explanations of behaviour in Milgram's "obedience' experiments. British Journal of Social Psychology, 56(4), 655-674.

Horne, M. (2007). There is no 'truth' outside a context: implications for the teaching of analytical psychology in the 21(st) century. Journal of Analytical Psychology, 52(2), 127-142. 
Imhof, R. (2017). Characters on the Couch: Exploring Psychology through Literature and Film. Reference \& User Services Quarterly, 56(3), 215-215.

Izod, J. (2000). Active imagination and the analysis of film. J Analytical Psychol., 45, 267-85.

Kaestner, L. (2015). Epistemic Cognition and Development: The Psychology of Justification and Truth. International Studies in The Philosophy of Science, 29(4), 444-447.

Kapczynski, J. (2015). Screen Nazis: Cinema, History and Democracy. Screen, 56(2), 289-293.

Kaposi, D. (2017). The resistance experiments: Morality, authority and obedience in Stanley Milgram's account. Journal for the Theory of Social Behaviour, 47(4), 382-401.

Klevan, A. (2014). Vertigo and the Spectator of Film Analysis. Film-Philosophy, 18, 147-171.

Lacan, J. (2007). Seminario X. La angustia. Buenos Aires: Paidós.

Lacan, J. (1992). Seminario XVII. El reverso del psicoanálisis. Buenos Aires: Paidós.

Laucht, C. (2008). Film propaganda in Britain and Nazi Germany: World War II cinema. Historical Journal of Film Radio and Television, 28(1), 8082.

Lurigio, A. (2009). The Rotten Barrel Spoils the Apples: How Situational Factors Contribute to Detention Officer Abuse Toward Inmates A Review of The Lucifer Effect, by Philip Zimbardo. Prison Journal, 89(1), 70S-80S.

Martin, E. \& Vioulac, J. (2014). Totalitarism without a state. Liberte, 303, 11-17.

Neumann, J. (2013). Die Auseinandersetzung mit Auschwitz durch das Medium Film im Religionsunterricht. Eine Filmanalyse zu «Die Welle». Berlin: Grin.

Nieto, M. \& Aleixandre, V. (2009). LA OLA. Manipulación y control a través de la imagen. Red Visual. Miradas sobre cine, 11.
O'Brien, M. (2009). Nazi Cinema as Enchantment: The Politics of Entertainment in the Third Reich. Forum for Modern Language Studies, 45(2), 228-229.

Oh, J., De Gagné, J. y Kang, J. (2013). A review of teaching-learning strategies to be used with film for prelicensure students. J Nurs Educ. 52, $150-6$.

Oz, A. (2004). Una historia de amor y oscuridad. Madrid: Silueta.

Penarik, N. (2015). Analyse der didaktischen werte in dem film "die welle" Von Dennis Gansel (Tesis de doctorado). Universitas Negeri Medan, Medan, Indonesia.

Rulinskiy, V. (2016). Overcoming Nazi past in Germany at the present stage. Goldhagen phenomenon. Contemporary Europe-Sovremennaya Evropa, 5, 67-78.

Silva, E. (2017). Hannah Arendt and Agamben: totalitarism as a biopolitic category and the politization of life in liberal democratic societies. Kalagatos, 14(2), 271-287.

Spackman, B. (2006). The unmaking of fascist aesthetics. Political Communication, 23(3), 355358 .

Stefanoni, P. (2011). Extremas derechas. ¿Del racismo al culturalismo? Página 7.

Tapper, M. (2013). Nazisploitation! The Nazi Image in Low-Brow Cinema and Culture. Historical Journal of Film Radio and Television, 33(1), 176178.

Turowetz, J. y Hollander, M. (2018). From "Ridiculous" to "Glad to Have Helped": Debriefing News Delivery and Improved Reactions to Science in Milgram's "Obedience" Experiments. Social Psychology Quarterly, 81(1), 71-93.

Ubilluz, J. (2009). El fantasma de la nación cercada. En: J. Ubilluz, V. Vich y A. Hibbett (Eds.), Contra el sueño de los justos: La literatura peruana ante la violencia política (pp. 19-85). Lima: IEP. 
Von Moltke, J. (2007). Nazi cinema revsited. Film Quarterly, 61(1), 68-72.

Wolf, K. (2018). Power struggles: A sociological approach to activist communication. Public Relations Review, 44(2), 308-316.

Yukselbaba, U. (2017). Milgram experiment about authority and obedience. Journal Of Istanbul University Law Faculty-Hukuk Fakultesi Mecmuasi, 75(1), 227-270.

Zizek, S. (2004). La suspensión política de la ética. México DF: Fondo de Cultura Económica.

\section{FILMOGRAFÍA}

Gansel, D. (2008). Die Welle [La Ola]. Berlín: Rat Pack Filmproduktion. 


\section{La búsqueda de la felicidad doméstica en La città e la casa de Natalia Ginzburg}

\section{Por: Máster María Belén Castanoํㅜ, Universidad de Buenos Aires, Argentina}

Recibido: 10 de setiembre, 2017.

Aprobado: 10 de marzo, 2018.

\section{RESUMEN}

La novela epistolar La città e la casa (1984) de Natalia Ginzburg aborda, como varias de las obras tardías de la autora, la crisis de la familia tradicional pequeñoburguesa. En particular, se analizarán las diferentes imágenes que se desprenden del concepto de casa presentes en la novela vinculadas a la melancolía, en las que es posible evidenciar la dicotomía entre el ámbito del hogar y del trabajo que resguarda la ilusión de felicidad doméstica de sus protagonistas. Esta dicotomía permite reflexionar sobre la hipótesis de análisis acerca de la escisión entre la esfera pública y la privada que afecta a los personajes pertenecientes a las clases medias urbanas de la novela y sobre la función social de esta obra como testimonio histórico de su tiempo.

Una reflexión sobre el sentido de derrota que se desprende de esta novela está en consonancia con el pesimismo que caracteriza a la amplia producción ficcional y ensayística de la obra de Ginzburg, en personajes invadidos por el tedio, cuyas dificultades de formular sus crisis -en este caso- se cristalizan en diferentes mudanzas, a través de las que se proponen escapar de su alienación.

\section{ABSTRACT}

\section{The search for domestic happiness in Natalia Ginzburg's La città e la casa}

Natalia Ginzburg's (1916-1991) epistolary novel La città e la casa [1984] addressesas do several of the author's late works - the crisis of the traditional institution of the petit bourgeois family. Specifically, we will address the various images of "home" present in the novel that relate to melancholy and alienation, revealing in turn a dichotomy between the home and work environment. This dichotomy allows us to explore the analyzing hypothesis of a division between the public and private spheres that the main characters belonging to the urban middle classes undergo, and this work's social role as a historical testimony of its time.

This study also intends to explore the sense of defeat that emerges from this novel, as reflected by characters invaded by ennui, whose difficulty to formulate their crisis crystallizes in different moves, through which they intend to escape from their alienation.

1 María Belén Castano es máster en Edición y Comunicación, graduada del Comunika Institute y Palombi Editori, en Italia, y Licenciada en Ciencia Política de la Universidad de Buenos Aires. Actualmente realiza su doctorado en Letras con una beca del Consejo Nacional de Investigaciones Científicas y Técnicas, Argentina, y trabaja en la sección de Literaturas en Lenguas Extranjeras del Instituto de Filología y Literaturas Hispánicas "Dr. Amado Alonso", de la Universidad de Buenos Aires. Contacto: belcastano@gmail.com.

PALABRAS CLAVE:

Natalia Ginzburg, literatura europea, literatura contemporánea, literatura nacional, alienación, clase media.

\section{KEY WORDS:}

Natalia Ginzburg, European literature, contemporary literature, national literature, alienation, middle class. 


\section{INTRODUCCIÓN}

La città e la casa [1984] es una novela epistolar, encuadrada en la producción tardía de Ginzburg, escrita un año después de haber sido electa como diputada en el Parlamento, en la lista independiente del Partido Comunista Italiano. Las otras novelas epistolares que Ginzburg ha publicado son Caro Michele (1973) y La famiglia Manzoni (1983).

La novela entera está basada en los diferentes puntos de vista de las narraciones que los personajes realizan intercambiando cartas. El lector percibe puntos de vista disímiles sobre los mismos sucesos que involucran a los distintos correspondientes. El arco temporal de esta obra abarca un año y medio entre la primera carta y la última, con la que se cierra la novela. En las fechas de estas cartas no está señalado el año, sino que solo se indican los meses, lo cual no permite inferir un contexto histórico preciso para situar la obra. Sin embargo, las declaraciones de la autora presentes en la entrevista "Ultime lettere di gente comune" que le realiza Severino Cesari, publicada en el Diario II Manifesto el 18 de diciembre de 1984, advierten sobre la ambientación de La città e la casa en la época de producción de la novela. De hecho, en estas entrevistas Ginzburg sostiene que esta novela tiene un carácter testimonial en relación con su contexto de producción, como también lo tiene la novela corta Famiglia (Ginzburg, 1997, p. 244). Las historias transcurren en ubicaciones geográficas diferentes. Las principales son: la ciudad de Roma, la provincia de Umbría y la ciudad de Princeton.

Uno de los temas centrales de La città e la casa es el lugar que ocupa en la identidad de los personajes la elección de las ciudades en las que viven y las casas en las cuales transcurren sus historias. En cada carta, los protagonistas intentan reconstruir su sentido de pertenencia en relación con los espacios físicos habitados. Como escribe Giuseppe sobre su casa luego de haberla vendido: "Esta todavía es mi casa y lo será siempre. Uno las casas puede venderlas o cederlas a otros todo lo que quiera, pero las conserva igualmente para siempre dentro de sí" (Ginzburg, 1997, p. $178^{4}$ ). En italiano: "Quella è ancora casa mia e lo sarà sempre. Uno le case può venderle o ceder- le ad altri finché vuole, ma le conserva ugualmente per sempre dentro di sé". Cuando Giuseppe trata de adaptarse a la vida en Estados Unidos, sostiene que en un cierto momento de la vida las cosas nuevas no le generan emoción, sino más bien indiferencia:

En América existirán otras plazas, con turistas, mendigos y sirenas. Pero serán indiferentes para mí, porque en la vida uno no puede hacer suyas muchas cosas. En un cierto momento de la vida, todo sobre lo que posamos los ojos por primera vez nos resulta extraño. Lo miramos como turistas, con interés pero fríamente. Pertenece a los otros (In America ci saranno altre piazze, con turisti, mendicanti e sirene. Ma a me saranno indifferenti, perché non è che uno nella vita può fare sue troppe cose. A un certo punto nella vita, tutto quello su cui posiamo gli occhi per la prima volta ci è estraneo. Lo guardiamo da turisti, con interesse ma freddamente. Appartiene agli altri) (Ginzburg, 1997, p. 36).

La novela afronta, como varias de las obras tardías de la autora, la crisis de la pequeña burguesía y la institución tradicional de la familia, y está ambientada en la misma época de producción de la obra. El protagonismo que cobran las cuestiones domésticas de personajes pequeñoburgueses recorre todo el trabajo de la autora.

Los objetivos de este artículo son analizar las diferentes imágenes, tipos y figuras de las casas presentes en La città e la casa, dando cuenta de los rasgos particulares que presentan en relación con el tedio y la melancolía, ligados no solo a la expresión de la crisis del sujeto moderno, sino también a la alienación del capitalismo tardío. La hipótesis de análisis se basa en poner a la luz la dicotomía entre el ámbito del hogar y el del trabajo, que resguarda la ilusión de felicidad doméstica de los protagonistas de esta obra, pertenecientes a clases medias urbanas, en el contexto de Italia en los años 80. Esta dicotomía permite reflexionar sobre la escisión entre la esfera pública y la privada, que atraviesa a dichos personajes y sobre la función social de esta obra como testimonio histórico de su tiempo.

$4 \quad$ A menos que se indique lo contrario, las traducciones del italiano al español de Natalia Ginzburg citadas aquí, son trabajo de la autora de este artículo. 
En la segunda sección se delinearán los principales aportes identificados por parte de la crítica literaria vinculados a la hipótesis de análisis de La città e la casa. En el tercer y cuarto apartado se hablará de los marcos teóricos utilizados en este trabajo sobre melancolía y alienación.

Para apoyarse en una definición de melancolía se remitirá a la particular representación de Ginzburg de la sociedad italiana postindustrial como un escenario signado por la tristeza y el tedio, a través de una configuración estética en la que se recrean algunos de los topoi más característicos de la elaboración artística, literaria y filosófica de la melancolía, con apoyo de la contribución teórica de Jean Starobinski (2012). Para aproximarse a una definición sobre la alienación este artículo se basa en los análisis del joven Karl Marx presente en los Manuscritos económicofilosóficos (1844), con el fin de indagar el vínculo que se desprende de la novela de Ginzburg entre la melancolía y la pérdida de la esencia genérica humana en la vida cotidiana bajo el capitalismo. En el quinto apartado se analizará las diferentes imágenes, tipos y figuras vinculadas con el concepto de casa en la novela y su nexo con el tedio y la melancolía, así como las ilusiones que se esconden detrás de las mudanzas de los protagonistas. El sexto apartado se trata de la conclusión de este trabajo, apoyada en el aporte de Walter Benjamin (2005) en el Exposé "París, capital del siglo XIX" sobre la escisión entre la esfera pública y la privada que se juega en los hogares pequeñoburgueses.

La temática de las ciudades y las casas recorre toda la obra de Ginzburg, cuya impronta autobiográfica va de la mano de una tematización recurrente del papel de la memoria y la escritura para dar cuenta de los recuerdos. Este es el caso de la producción ensayística, que presenta una elaboración constante de las distintas ciudades habitadas por Natalia Ginzburg: Turín, la ciudad en la que transcurre su infancia y su juventud, y en la que conoce a Leone Ginzburg y el círculo de intelectuales antifascistas de la Editorial Einaudi; Roma, en la cual se instala definitivamente desde la posguerra hasta su muerte y cuyo paso durante la Segunda Guerra Mundial la marca profundamente a raíz de la muerte de Leone, torturado por el fascismo en las cárceles de Regina Coeli, época en la que se refugia junto a sus hijos de la persecución alemana en un convento de monjas en Via Nomentana (Pflug, 2004, p. 64) y Londres, donde se muda por dos años, debido a un trabajo de su segundo marido Gabriele Baldini, que asume como director del Instituto Italiano de Cultura de Londres (Pflug, 2004, p. 103).

En "Ritratto de un amico", incluido en su primer libro de ensayos (1962), tematiza la nostalgia de Turín, la ciudad de su infancia y en la que pierde a su amigo Cesare Pavese, que evoca siete años después de su suicidio (Ginzburg, 1998, p. 18).

En "Elogio e compianto dell'Inghilterra", Ginzburg (1962) elabora consideraciones sobre el período en el que vivió en Inglaterra, en un país que para ella tenía una impronta de melancolía (Ginzburg, 1998, p. 35). En el ensayo "La casa" (1970), se ocupa de la dificultad para encontrar una casa en Roma y reflexiona sobre el deseo que las personas tienen de vivir en un espacio similar a aquel en el que transcurrió la infancia o en lugares en los que en algún momento de la vida se habrán echado raíces. También aborda la representación de la casa como un lugar de refugio y recurre a la metáfora de la cueva y la media vieja (Ginzburg, 2002, pp. 8-9). A su vez, en los ensayos "Così è Roma" e "Infelici nella città bella e orrenda" pone a la luz nuevamente la nostalgia de Turín y los recuerdos de Roma y trata las distintas contradicciones de las ciudades y el complejo papel de la memoria al recordar las urbes habitadas en el pasado (Ginzburg, 1974, pp. 201-202). Aquí se ocupa también de la dificultad del lenguaje para dar cuenta de la infelicidad de los hombres (Ginzburg, 1974, p. 200).

La idealización de la vida en las ciudades, en comparación con la vida rural, es un motivo que se repite en varias de las obras de ficción de Ginzburg. Al mismo tiempo, sus protagonistas experimentan un proceso de derrumbe de dichas idealizaciones y se sienten abatidos por la soledad y una sensación de fracaso al no poder insertarse -como deseaban- en la vida de las ciudades dominadas por las reglas y conductas de la sociedad de consumo. Esto revela una crítica, en buena parte implícita, a la existencia alienada del capitalismo tardío. Ya en su primera novela corta, La strada che va in città (1942), Delia, la protagonista, abandona repentinamente la adolescencia y el hogar de sus padres y sus hermanos en el campo para for- 
mar un hogar propio, luego de un embarazo que la lleva a mudarse con una pareja que no ama, a una ciudad que le despierta sentimientos contradictorios. En la novela Tutti i nostri ieri (1952), al igual que Delia, la joven Anna tiene un embarazo adolescente y sufre un proceso de desarraigo familiar de su ciudad cuando se casa con un hombre mucho mayor que ella, Cenzo Rena y se va a vivir con él a un pueblo que desprecia y compara con su pequeña ciudad de origen. En las obras de teatro, como en Ti ho sposato per allegria (1965), L'inserzione (1965) y Fragola e Panna (1966), los personajes femeninos provienen del campo e idealizan la ciudad, a la que se trasladan en busca de trabajo, ascenso social y diversiones. En Caro Michele, Adriana abandona la ciudad para mudarse a una casa en el campo luego de su separación. Allí se siente sola y atraviesa un proceso de depresión que la lleva a odiar la naturaleza que la rodea y permanecer incomunicada con sus afectos. El tema central de las dos novelas cortas Famiglia y Borghesia (1977), al igual que Caro Michele, también gira en torno a la crisis en los espacios domésticos de las urbes, encarnados en el cáncer que contraen Carmine e llaria a mediana edad, enfermedades que aparecen representadas como el corolario de su alienación. Irónicamente, mientras en Famiglia el arquitecto Carmine intenta escribir un libro sobre las ciudades y las periferias, y anhela mudarse al campo, como el médico Amos Elía, en Borghesia, Ilaria sueña con abandonar la ciudad en la que vive para continuar su carrera de escritora en una casa junto al mar.

\section{INFELICIDAD DOMÉSTICA}

¿En qué medida es posible identificar en los personajes de La città e la casa un malestar que se relaciona con la infelicidad doméstica y la melancolía? Este interrogante permite profundizar la hipótesis de lacoli (2008, p. 72), que subraya el aspecto "domocéntriCo" de La città e la casa y lo que Ginzburg advierte como la plaga de su tiempo: la desintegración de las familias. También identifica lacoli elementos desmitificadores que corroen las fórmulas del sentido común de las clases medias, como las acotaciones de Roberta, la prima del protagonista, que repite en varias ocasiones -como un mantra-que nunca hay que vender el ladrillo o que la compra del ladrillo nunca desilusiona. Mientras, en la narración se da una obli- teración de estas aseveraciones, ya sea por parte de Giuseppe, que vende su casa en Roma y emigra a Estados Unidos o de Lucrezia que vende su casa en el campo y se muda a la ciudad (lacoli, 2008, p. 74).

Para lacoli (2008, p. 72) esta obra cuestiona las certezas burguesas y sostiene que detrás de la ilusoria promesa de protección de las casas se esconden varios motivos vinculados a la infelicidad familiar. Esta reflexión encuentra una afinidad con la de Surdich (1995, p. 15), quien advierte una dimensión ideológico-política de los escritos de la autora desde su primer cuento (Un'assenza) y afirma que Ginzburg contrapone a la retórica fascista un intimismo doméstico que intenta remover el velo de convencionalidad e hipocresía que la retórica del régimen promovía y legitimaba. Surdich (1995, p. 19) considera que Ginzburg se dirige ante todo a un público lector femenino, al tematizar la familia como un lugar de agresiones, opuesto a la ilusión de la serenidad doméstica y felicidad. Por otro lado, se considera necesario ampliar los análisis de Sanvitale (1986, p. 38) sobre La città e la casa, en los que cobra relevancia la inmovilidad de los personajes, quienes no experimentan cambios internos sustanciales a pesar de las diferentes modificaciones en sus vidas: todos dan cuenta de una verdad que querrían formular, pero que no se enuncia y la casa se convierte-entonces- en el lugar encargado de representar un entramado de procesos repetitivos y alienantes. Pflug cita declaraciones de Ginzburg sobre La città e la casa y su visión sobre el carácter fragmentario de estas historias:

Hoy la realidad es oscura, fragmentaria, incoherente e indescifrable [...]. Escribiendo novelas, siempre tuve la sensación de tener en la mano espejos rotos, y sin embargo siempre esperaba poder recomponer finalmente un espejo entero...Esta vez no obstante, desde el inicio, no esperaba nada (Oggi la realtà è oscura, frammentaria, incoerente e indecifrabile. [...] Scrivendo romanzi, ho sempre avuto la sensazione d'avere in mano degli specchi rotti, e tuttavia sempre speravo di poter ricomporre finalmente uno specchio intero...Questa volta però, fin dal principio, non speravo nulla) (Pflug, 2004, pp. 155156). 


\section{HOGAR, MELANCOLÍA, NOSTALGIA Y EXILIO}

¿De qué modo cabría relacionar el hogar con la melancolía? El nexo entre ambos puede ser puesto en relación con el vínculo entre el concepto de nostalgia, hogar y el de exilio. Las consideraciones de Starobinski sobre la historia de los sentimientos y su ligazón con el lenguaje destacan que los sentimientos sobre los que se quiere reconstruir una historia son accesibles a las personas solo en el momento en el que son manifestados verbalmente o por cualquier otro medio expresivo. Cita las palabras de La Rochefoucauld (2012, p. 207), según el cual, hay personas que no se habrían enamorado nunca si no hubiesen escuchado hablar sobre el amor.

Starobinski se detiene en la primera aparición del concepto de nostalgia en la tesis del médico suizo Johannes Hofer de Mulhouse (1688), quien crea este término por primera vez para expresar un sentimiento particular (nostalgia) que sentían los soldados cuando estaban lejos de su patria; un neologismo que se remonta a términos griegos, ya que "nostalgia" es la composición de retorno (nóstos) y dolor (álgos) (Starobinski, 2012, pp. 210-211).

La nostalgia por los hogares que abandona cada uno de los personajes cuando se muda, en especial Giuseppe y Lucrezia, se explicita en la novela y se vincula con sus interrogantes en relación con una búsqueda de comprensión de su identidad. A su vez, es posible identificar la particular caracterización estética de Ginzburg de la sociedad italiana postindustrial de los años 80, en la que está ambientada esta novela, como un escenario signado por la tristeza en personajes que se destacan por dar cuenta de la plasmación de un contexto marcado por la angustia y el ennui propios de un mundo que no parece tener razones ni fines determinados.

\section{ALIENACIÓN Y MELANCOLÍA}

Las actitudes melancólicas de los personajes que se examinarán a continuación están ligadas con la insatisfacción y el tedio de sus vidas y el deseo de modificar algo de ello conformando un nuevo hogar en un lugar diferente a través de las numerosas mudanzas que realizan. Principalmente, en este trabajo el enfoque es analizar la melancolía como un sínto- ma de alienación y crisis del sujeto moderno en un mundo cosificado, cuyo tedio se deriva -en gran parte- de la pasividad del hombre moderno aislado del proceso de producción signado por la racionalidad instrumental. Se tratará entonces de delinear una definición de alienación basada en las consideraciones del joven Marx.

En el célebre análisis realizado por él en los Manuscritos económico-filosóficos (1844), se destaca que con la instauración del trabajo alienado el trabajador se pierde a sí mismo y a la vez, su ser genérico (Gattungssein) y su esencia genérica (Gattungswesen). Aun cuando la melancolía se puede relacionar puntualmente con trastornos y perturbaciones mentales, se propone aquí indagar el vínculo que se desprende de la novela de Ginzburg entre la melancolía y la pérdida de la esencia genérica humana en la vida cotidiana bajo el capitalismo.

El análisis de Marx sobre la alienación (Entfremdung) y la enajenación (Entäußerung) del trabajador permite reflexionar sobre la elaboración en La città e la casa de la primacía de la intimidad del espacio doméstico como lugar de realización y felicidad, en oposición con la infelicidad y el tedio ligados al ámbito de trabajo, una ilusión que se juega en cada una de las elecciones de los personajes pequeñoburgueses de esta novela. Cabe recordar que, en los Manuscritos, Marx no se refiere a la alienación de las clases medias, sino ante todo a la del trabajo material, productor de mercancías. En primer lugar, Marx destaca que la alienación "no se muestra solo en el resultado, sino el acto de producción dentro de la propia actividad productora" y entiende que en ese mismo acto de producción el trabajador también se aliena a sí mismo (Marx, 2015, p. 109). Cuando Marx se refiere a la enajenación del trabajo, observa que "el trabajo es externo al trabajador, es decir: no pertenece a su esencia; consiste, por ende, en que el trabajador no se afirma en su trabajo; sino que se niega; en que no se siente bien, sino desdichado" (Marx, 2015, p. 109). En este sentido, solo puede encontrar satisfacción fuera de su trabajo, al que considera como un "autosacrificio de castigo".

En la definición del hombre como un ser genérico, Marx extrae una ulterior determinación del trabajo alienado. Para él, el hombre es un ser genérico 
"porque se relaciona consigo mismo como con el género actual y vivo, porque se relaciona consigo mismo como un ser universal, y por ello libre" (Marx, 2015, p. 111). Para Marx, "el trabajo, la actividad vital, la vida productiva misma, se le aparece, al hombre solo como un medio para la satisfacción de una necesidad, la necesidad de conservación de la existencia física" (Marx, 2015, p. 112). Asimismo, diferencia al animal del hombre justamente el hecho de que "el animal está inmediatamente unido a su actividad vital", mientras el hombre "convierte su actividad vital misma en objeto de su voluntad y de su conciencia" (Marx, 2015, p. 112). De ahí que "el trabajo alienado invierte la relación, y hace que el hombre, precisamente porque es un ser consciente, convierta su actividad vital, su ser, en mero medio para su existencia" (Marx, 2015, p. 113).

Es posible identificar un malestar de los personajes de estas obras que está vinculado a la definición de alienación que se toma de Marx, cuyos indicios más numerosos se ubican en el espacio doméstico. Es allí donde es posible evidenciar una oposición entre su deseo de realizarse a través de la conformación de un hogar, encarnado en la importancia que cobran las diferentes mudanzas de las casas y las ciudades en la trama de La città e la casa, y la dificultad para encontrar satisfacciones en el ámbito laboral. Sin embargo, en cada uno de estos hogares cobran fuerza las frustraciones y las quejas en relación con el tedio de sus ocupaciones, la falta de una vocación auténtica y la dificultad para vincularse de un modo genuino entre sí.

A pesar de las dudas que los invaden, hay una certeza que prevalece en los personajes de esta novela: su deseo de mudarse, el cual encarna un anhelo de estabilidad de las clases medias basado en el lugar simbólico que ocupan las casas en la narración y también en la ilusión que se desprende de esta trama basada en la creencia de que al cambiar de casa podrían dejar atrás su alienación.

\section{LAS IMÁGENES DEL HOGAR VINCULADAS A LA MELANCOLÍA}

Las imágenes, tipos y figuras del hogar que prevalecen en la obra -tal como sostienen los análisis de lacoli (2008), Surdich (1995), Sanvitale (1986) y las declaraciones mismas de la autora presentes en la biografía de Pflug (2004) mencionadas- están vinculadas con la tristeza y la insatisfacción de sus protagonistas. En primer lugar, es posible identificar un vínculo entre alienación y melancolía, y la pérdida de lo que Marx denomina la esencia genérica humana en la vida cotidiana bajo el capitalismo en las dificultades de realización que los protagonistas manifiestan en la obra y los llevan a buscar soluciones en las mudanzas... Giuseppe se queja sobre la falta de sentido de su trabajo como periodista; Lucrezia protesta por sus labores como ama de casa en el campo; Albina se cuestiona la soledad de su vida en Roma, ciudad en la que se dedica a dar clases de literatura y Serena fracasa en su intento de acercar a las mujeres a actividades feministas cuando funda un centro para la mujer en Pianura y tampoco le resulta sencillo insertarse en el mundo del teatro.

Al mismo tiempo, varias ilusiones se juegan en las numerosas mudanzas de los personajes que depositan la esperanza de dejar atrás sus penas a través de un cambio de vivienda y ciudad, tal como lo indica su título. La primera ilusión que se despliega en la novela es la de Giuseppe de mudarse a Estados Unidos para dejar atrás la monotonía y el hastío de su vida. La venta de su departamento en via Nazario Sauro responde a un acto de rebeldía de este personaje, el cual desobedece el consejo de su prima Roberta, que en varias ocasiones repite que no hay que vender nunca el ladrillo (Ginzburg, 1997, p. 6).

La segunda casa que aparece en las cartas de Giuseppe es la de via Torricelli, en la que su hijo habría transcurrido su infancia, ya que luego de la muerte de su madre se había trasladado allí y quedado al cuidado de su tía Bice, descripta por Giuseppe como una mujer cuyo falso optimismo inundaba las paredes de la casa. La tercera casa -que conforma un elemento central en la novela- es la de Piero y Lucrezia, apodada "Le Margherite", ubicada en las afueras de Roma cerca de Pianura. Es el lugar de encuentro para el núcleo de amigos y allí crecen varios hijos de ellos.

"Le Margherite" representa la ilusión de armonía familiar en la novela. El contraste entre la alegría que les brinda esta casa amplia, rodeada de naturaleza, en la que los hijos de Lucrezia corren y juegan, concede una imagen idílica en la trama que luego se irá 
desintegrando. Aquí se aborda un tema recurrente en las obras de Ginzburg: la dicotomía entre la vida del campo y la ciudad, ya mencionada. En una de las primeras cartas que Lucrezia le escribe a Giuseppe dice que le genera rechazo el campo y le gustaría irse a vivir a una ciudad como Princeton (Ginzburg, 1997, p. 23). Sin embargo, cuando ella se muda a Roma con la ilusión de convivir con sus hijos y su amante Ignazio Fegiz, y pide un préstamo para comprar una casa, su disconformidad aumenta, las dudas la invaden y manifiesta incertidumbre sobre el lugar en el que le gustaría vivir (Ginzburg, 1997, p. 220).

La cuarta casa que cobra importancia en la novela es la de Princeton, donde vive Ferruccio, el hermano de Giuseppe. Dicha casa se presenta cargada de esperanzas puestas en un porvenir diferente por parte de Giuseppe, que decide emigrar allí a los 50 años en busca de protección y paz.

Otros dos cambios de casas resultan relevantes en la obra. El primero es la mudanza de Albina, que deja el monoambiente que alquila en Roma para regresar a su pueblo de origen, Luco dei Marsi. Allí tiene la ilusión de dejar atrás su soledad, casándose con un fabricante de muebles mayor que ella, que no ama y cuya vida en conjunto termina resultándole muy tediosa. La segunda mudanza involucra al personaje de Serena, quien abandona el cuarto que alquilaba en Pianura para trasladarse al monoambiente de Albina.

No obstante, en tanto es cada vez más fuerte el deseo de los personajes de encontrar estabilidad habitando una casa con un núcleo familiar, la historia avanza irónicamente hacia una desintegración de cada uno de esos anhelos. A su vez, una tipología del hogar infeliz que aparece en la novela está vinculada con las memorias de los personajes, que evocan a través de las cartas los recuerdos de hogares desdichados en los que habrían transcurrido infancias marcadas por el tedio.

Giuseppe se siente culpable por haberle generado hastío a su hijo durante su infancia: "Pienso siempre en el gran tedio que reinaba entre su madre y yo, y que él bebía de a tragos por días y días, cuando era niño" ("Penso sempre alla grande noia che regnava fra me e sua madre, e che lui beveva a sorsate per giornate e giornate, quando era bambino") (Ginzburg, 1997, p. 12).

Alberico le reprocha a su padre que había sido deficitario y es por ello que decide hacerse cargo de la hija de su amiga Nadia, reconociéndola como suya ante el Estado (Ginzburg, 1997, p. 94). A partir del relato de Alberico también se sabe que la infancia de su amiga Nadia fue difícil. Igualmente, Lucrezia evoca con tristeza su infancia sin padre y con una madre con un carácter fuerte a la que obedecía (Ginzburg, 1997, p. 36). Asimismo, los personajes con los que Giuseppe se vincula en Estados Unidos también abordan relatos sobre infancias tristes, como es el caso de Anne Marie, Chantal y Danny.

Si bien, como menciona Surdich (1995), se evidencia la necesidad -presente en toda la producción de Ginzburg- de contraponer a la retórica fascista un intimismo doméstico que intenta remover el velo de la convención y la hipocresía que este promovía y legitimaba la dimensión ideológico-política antifascista de la autora aquí mencionada, se considera necesario añadir su vínculo con la melancolía.

De hecho, es posible explorar una multiplicidad de figuras melancólicas presentes en toda su producción, cuyo componente crítico encierra un cuestionamiento, implícito, al tedio y la alienación del capitalismo tardío. Cabe destacar que la intención de brindar un panorama que abarque todos los personajes melancólicos en la producción ficcional de Ginzburg excede las posibilidades de este trabajo y merece un estudio aparte. Sin embargo, se enumeran algunos casos de la producción ficcional temprana y tardía: la joven Anna en Tutti i nostri ieri (1952), la joven Elsa en Le voci della sera (1961), Michele y su padre en Caro Michele (1973), Giuliana en Ti ho sposato per allegria, Carmine en Famiglia (1977) e Ilaria en Borghesia (1977). En La città e la casa, algunos personajes experimentan un sentimiento de nostalgia por las casas en las que han habitado varios años y han dejado, como Giuseppe con la suya en Via Nazario Sauro y Lucrezia con su casa "Le Margherite", y se sienten extraños en las nuevas casas a las que se trasladan.

El personaje que se destaca por su melancolía es el protagonista, Giuseppe, que decide partir a Estados 
Unidos cuando se encuentra en un momento de crisis y depresión. Se siente agobiado por el tedio que le representa su rutinario trabajo como periodista y la falta de dinero. También se queja por la difícil relación que tiene con su hijo Alberico: "Cuando estamos juntos, nos cuesta con extrema fatiga decirnos las cosas más simples" ("Quando siamo insieme, facciamo un'estrema fatica a dirci le cose piú semplici") (Ginzburg, 1997, p. 9) y sostiene: "De mi hijo no sentiré su falta porque no lo veo nunca" ("Di mio figlio non sentirò la mancanza perché non lo vedo mai" [d]) (Ginzburg, 1997, p. 4). Este personaje manifiesta muchas vacilaciones antes de partir en todas sus cartas y siente nostalgia al dejar su ciudad. Al mismo tiempo, se define como un solitario: "No creo que haré nuevas amistades. Me he convertido, con los años, más bien en un solitario. Tenía aquí algunos amigos, no muchos, y los extrañaré. Pero de algo hay que sufrir también" ("Non credo che stringerò nuove amicizie. Sono diventato, con gli anni, piuttosto solitario. Avevo qui alcuni amici, non molti, e ne sentirò la mancanza. Ma di qualcosa bisogna pure soffrire") (Ginzburg, 1997, p. 3).

Giuseppe considera que al emigrar modificará su identidad y es por eso que utiliza en su carta la metáfora de arrojarse al agua: "Voy a América como uno que ha decidido tirarse al agua, y espera salir afuera o muerto, o nuevo y diferente" ("Vengo in America come uno che ha deciso di buttarsi nell'acqua, e spera di uscirne fuori o morto, o nuovo e diverso") (Ginzburg, 1997, pp. 3-4). Su melancolía está ligada con una actitud de indecisión permanente y ensimismamiento, de la mano de una falta de curiosidad hacia su entorno, que se explicita en una carta que le manda a Lucrezia: "no siento gran curiosidad por mi entorno, no me siento ni un visitador ocasional ni un habitante, sino uno que no sabe qué cosa ser y fija por todos lados una mirada indecisa" ("non sento gran curiosità di guardarmi intorno, non mi sento né un visitatore occasionale né un abitante, ma uno che non sa cosa essere e fissa ovunque uno sguardo indeciso") (Ginzburg, 1997, p. 62).

Sin embargo, a pesar de todas las advertencias y quejas de los correspondientes de la narración sobre la errónea decisión que para ellos habría tomado Giuseppe al partir, él encuentra -cuando llega a Princeton- una leve satisfacción al concretar aquellos pla- nes vinculados a su juventud que se había propuesto: enseñar en una escuela, andar en bicicleta y escribir novelas: "en América vuelvo a realizar las cosas que hacía de joven. Escribo una novela. Ando en bicicleta. Enseño" "in America torno a fare le cose che facevo da giovane. Scrivo un romanzo. Vado in bicicletta. Insegno") (Ginzburg, 1997, pp. 67-68). Tanto dar clases de italiano como escribir la novela titulada Il nodo -que luego intenta publicar- le dan mucha satisfacción, inicialmente, a este personaje. En una carta de Giuseppe dirigida a Piero realiza un análisis sobre sus derrotas, su inseguridad y el rechazo que siente por su persona cada mañana: "De hecho, por la mañana cuando me levanto, la primera cosa que siento por mí es un profundo desprecio por mi persona, por mis pies en las pantuflas, por mi triste rostro en el espejo, por mi ropa sobre la silla" ("Difatti, la mattina quando mi alzo, la prima cosa che trovo in me è un profondo disprezzo per la mia persona, per i miei piedi nelle ciabatte, per la mia triste faccia nello specchio, per i miei vestiti sulla sedia") (Ginzburg, 1997, p. 114).

La melancolía es una característica predominante también en su hijo Alberico, definido por Giuseppe como un carro fúnebre y una persona que ríe poco (Ginzburg, 1997, p. 12). Según las cartas de Giuseppe, se sabe que Alberico habría pasado una infancia marcada por el tedio de sus padres, la muerte temprana de su madre y luego había sido criado por su tía Bice. Cuando era un niño, se escapó de la casa de su tía en varias ocasiones y Giuseppe lo fue a buscar a la comisaría. Su padre recuerda con angustia la oportunidad en la que su hijo estuvo un mes en la cárcel junto a sus amigos debido a un problema de drogas en el "Carlifornia bar" al que concurría (Ginzburg, 1997, p. 13).

Dado que las cartas de Alberico son pocas, el lector obtiene información sobre su vida a partir de las narraciones de los otros personajes, que siempre lo nombran y brindan detalles exhaustivos sobre él. Todos ellos entablan una relación de amistad con Alberico y pasan tiempo con él. Piero lo define como alguien con un aire somnoliento y distraído, que siente curiosidad por el prójimo y esconde juicios agudos sobre su entorno (Ginzburg, 1997, p. 89). 
En una carta que le escribe Alberico a su padre cuando muere su tío Ferruccio, manifiesta las mismas dudas que Giuseppe respecto de los proyectos de su vida. Recuerda que había visto a Ferruccio tres veces en toda su vida y en esas tres ocasiones él le había aconsejado estudiar ingeniería, a lo que le había contestado que tenía planes distintos: "Pero si te soy sincero, estos programas los he cambiado continuamente, en el transcurso de los años. En el momento actual, no tengo ninguno" ("però a dirti il vero, questi programmi li ho cambiati continuamente, nel corso degli anni. Al momento attuale, non ne ho nessuno") (Ginzburg, 1997, p. 82).

La melancolía de Alberico está vinculada con una actitud crítica de su entorno. Tiene inclinaciones artísticas que canaliza a través de la escritura de guiones de cine. Se revela como el más complejo de todos los personajes y al igual que sucede con el joven Michele en Caro Michele, es asesinado de modo imprevisto. La película cuyo guión escribe y dirige lleva el título Devianza, que podría bien remitir a su capacidad de realizar un giro y desviarse de los planes que su entorno pequeñoburgués espera de él. Su carácter es el del outsider que está disconforme con la realidad que lo rodea.

La complejidad de Alberico también se revela en su reticencia a sentirse orgulloso del éxito masivo de su película, ya que ni siquiera asiste a su estreno. Se muestra disconforme con su éxito y se lo cuenta a su padre en una carta: "me he divertido al realizarlo, pero no me gusta. Pero si le gusta a los otros, tanto mejor" ("mi sono divertito a farlo, ma non mi piace. Però se piace agli altri, tanto meglio") (Ginzburg, 1997 , p. 179). Sus reflexiones sobre la velocidad con la que suceden las cosas en su tiempo lo dotan de una capacidad de análisis que lo diferencia de los jóvenes con quienes se vincula.

Serena, al igual que Alberico, tiene inclinaciones artísticas e intenta abrir en Pianura un "Centro Donna", en el que se propone actuar como Gemma Donati, la mujer de Dante, en una comedia que ella escribeGemma e le fiamme-, a cuya representación acuden muy pocas personas (Ginzburg, 1997, p. 58). Cuando Serena se muda a Roma, se involucra en una relación con un director de teatro y actúa también en la Mirra de Alfieri. Aunque no obtiene buenas críticas, es el único personaje que se encuentra contento al final de la obra (Ginzburg, 1997, p. 163).

Otra tipología predominante vinculada con el hogar que subyace en la obra y se retomará en la conclusión de este trabajo es la de aquellos personajes outsiders que escapan a la alienación y la escisión entre la esfera pública y la privada que se juega en la mayoría de los personajes de la novela. ¿Por cuál motivo hablar de escisión entre dichas esferas en el espacio doméstico? Si el hogar pequeñoburgués representa el lugar donde los individuos anhelan encontrar un ámbito de satisfacción que procure llenar la insatisfacción dada por el tedio y la cosificación de sus ocupaciones, es entonces el espacio privado el que ocupa un lugar privilegiado, por encima del espacio público, en el que lo individual prima sobre lo colectivo y lo social, y se busca una autenticidad en los vínculos. Sin embargo, en la desconexión con lo social y la exaltación del individualismo pequeñoburgués del interior se acentúa el carácter utilitario de los sujetos convertidos en objetos, cuyas metas individuales se ven teñidas por el tedio.

Estos valores individualistas y la incapacidad para formular sus crisis representan a varios personajes, como Lucrezia, Ferruccio, Albina, Egisto e Ignazio Fegiz, que se oponen a Giuseppe, Alberico y Serena, cuya predisposición melancólica les otorga una visión crítica de su entorno, la cual les permite una elaboración particular del tedio. Su disconformidad los lleva a cuestionar las certezas burguesas. Ellos -al contrario- no tienen certezas, sino que dudan constantemente de todo y adoptan la postura del outsider, cuyo refugio encuentran en la expresión artística.

En La città e la casa, las cartas cumplen la función de poner en palabras y elaborar el tedio de los individuos y la pérdida de la esencia genérica en la existencia bajo el capitalismo tardío. No obstante, en dichas cartas se asiste a una incapacidad de la mayoría de los personajes de formular una reflexión ligada al tedio y la alienación, con la excepción de Giuseppe, Alberico y Serena, cuya actitud de outsiders y su vínculo con el arte los diferencia de los demás: Giuseppe escribe una novela, Alberico es director y escritor de guiones cinematográficos y Serena se dedica al teatro e intenta fundar un centro cultural feminista. El carácter no alienado de dichas eleccio- 
nes encarna una reflexión de esta novela sobre el arte como función utópica para emancipar al hombre de la cotidianidad cosificada del capitalismo tardío.

\section{CONCLUSIÓN: LAS CASAS Y LA ESTABILIDAD DE LOS NÚCLEOS FAMILIARES COMO ANHELOS DE LAS CLASES MEDIAS}

Si bien esta novela -al igual que otras obras de Ginzburg- pone en primer plano la crisis del modelo tradicional familiar expresada en las diferentes dificultades de comunicación entre padres e hijos y crisis de parejas, el objetivo es analizar las diferentes imágenes del hogar vinculadas con la melancolía y el sentido de derrota que se desprende de la obra, vinculadas con el modo en que los protagonistas intentan alejarse del tedio.

Mientras el tema principal que la novela pone a la luz es el lugar que ocupa en la identidad de los personajes la elección de las ciudades en las que viven y las casas en las cuales transcurren sus historias, es posible notar que detrás de cada mudanza se asiste a una desilusión respecto a los deseos de bienestar futuros depositados en dichos cambios de hogares. Muchos personajes depositan ilusiones de encontrar la felicidad con las respectivas mudanzas: Giuseppe, trasladándose de Roma a Princeton; Lucrezia, de Pianura a Roma; Albina, de Roma a Luco dei Marsi y Serena, de Pianura a Roma. Y al mismo tiempo, la insatisfacción persiste en todos ellos a pesar de los cambios de casas que realizan. Las imágenes de las viviendas que se estudiaron están vinculadas con el tedio y la tristeza, y se asiste en la narración a la evocación de recuerdos de infancias en hogares marcados por la desdicha.

Tal como sostiene lacoli (2008), se despliega en La città e la casa una desmitificación del sentido común de las clases medias y un cuestionamiento de las certezas burguesas. Del mismo modo, el análisis de Sanvitale (1986) sobre la incapacidad de los personajes para expresar una verdad que no se formula se puede vincular con una conciencia que permanece velada para estos personajes. A su vez, es posible indagar que estas obras ponen a la luz una felicidad doméstica en la que se encierra un componente de falsa conciencia, propio de las ilusiones pequeñoburguesas del ámbito privado. Para profundizar esto, resulta sugestivo el análisis de los Manuscritos sobre cómo el trabajo alienado invierte una relación en la que se diferencia al hombre del animal, ya que su actividad vital se convierte en medio para satisfacer necesidades ligadas a su existencia, necesidades cuyo espacio es posible ubicar en el interior de lo doméstico: lugar en el que se deposita la ilusión de búsqueda de felicidad de las clases medias.

Tal como postula Benjamin (2005) "para el particular, el espacio de la vida aparece por primera vez como opuesto al lugar de trabajo. El primero se constituye en el interior. La oficina es su complemento" (p. 43), una dicotomía entre el ámbito del hogar y el laboral que resguarda la ilusión de felicidad doméstica.

El particular, que en la oficina lleva las cuentas de la realidad, exige del interior que le mantenga en sus ilusiones. Esta necesidad es tanto más urgente cuanto que no piensa extender sus reflexiones mercantiles al campo de las reflexiones sociales. Al configurar su entorno privado, reprime a ambas. De ahí surgen las fantasmagorías del interior. Para el particular, el interior representa el universo. En él reúne la distancia y el pasado. Su salón es un palco en el teatro del mundo (Benjamin, 2005, p. 43).

Según Benjamin (2005), para el burgués habitar significa dejar huellas y es a partir del estudio de las huellas en el espacio interior burgués del siglo XIX en las que se inspira para analizar los motivos vinculados a las ilusiones burguesas del ámbito privado. $\mathrm{Si}$ el individuo se entrega al cálculo en la oficina, en el interior de su casa quiere mantener sus ilusiones en un ámbito opuesto al de las reflexiones sociales y en cuyo espacio priman la falsa conciencia y las fantasmagorías, propias de la vida moderna.

El protagonismo que cobran los numerosos fracasos y sentimientos de desdicha por parte de personajes que buscan la felicidad en el ámbito privado deja abierto un interrogante que posibilita un cuestionamiento sobre las certezas pequeñoburguesas, tal como señala el análisis de lacoli (2008) y la dicotomía que permea el ámbito público y el privado de varios personajes de esta novela, marcados por una imposibilidad de formular sus crisis por la búsque- 
La búsqueda de la felicidad doméstica en La città e la casa de Natalia Ginzburg

da de soluciones individuales por encima de las colectivas y sociales. En oposición a estos personajes, se destaca en el análisis el carácter de outsiders de aquellos que están vinculados a la melancolía, como Giuseppe, Alberico y Serena, cuya actitud crítica de su entorno les permite cuestionar las certezas pequeñoburguesas, escapando a la escisión entre público y privado.

A su vez, vale la pena destacar que el carácter no alienado de las elecciones de Giuseppe, Alberico y Serena -que son capaces de expresarse a través de diferentes ámbitos artísticos- encarna una reflexión de esta novela sobre el arte como función utópica para emancipar al hombre de la cotidianidad cosificada del capitalismo tardío. Esto ayuda a problematizar la pertinencia de analizar la función crítica de la melancolía en relación con la alienación de las clases medias del capitalismo tardío en un contexto de producción de la obra que coincide con el de la época y adquiere un carácter testimonial.

\section{REFERENCIAS BIBLIOGRÁFICAS}

Benjamin, W. (2005). Libro de los Pasajes (Trad. de Fernández Castañeda, L., Herrera, I. y Guerrero, F.). En Tiedemann, R. (Ed.). Madrid: Ediciones Akal.

Cesari, S. (18 de diciembre de 1984). Ultime lettere di gente comune. Diario II Manifesto.

Ginzburg, N. (1942). La strada che va in città. Torino: Edit. Einaudi.

Ginzburg, N. (1952). Tutti i nostri ieri. Torino: Edit. Einaudi.

Ginzburg, N. (1962). Le vocci della sera. Torino: Edit. Einaudi.

Ginzburg, N. (1962). Le piccole virtú. Torino: Edit. Einaudi.

Ginzburg, N. (1965). Ti ho sposato per allegría. Madrid: Editorial Klett.

Ginzburg, N. (1970). Mai devi domandarmi. Torino: Edit. Einaudi.
Ginzburg, N. (1970). Mai devi domandarmi. Turín: Edit. Einaudi.

Ginzburg, N. (1973). Caro Michele. Turín: Edit. Einaudi.

Ginzburg, N. (1974). [1974]. Vita immaginaria. Milán: Mondadori.

Ginzburg, N. (1977). Famiglia. Torino: Edit. Einaudi.

Ginzburg, N. (1977). Borghesia. Torino: Edit. Einaudi.

Ginzburg, N. (1993). [1964]. Cinque Romanzi brevi. Introducción de Garboli, C. Turín: Einaudi.

Ginzburg, N. (1994). [1983]. La famiglia Manzoni Turín: Einaudi.

Ginzburg, N. (1996). [1952]. Tutti i nostri ieri. Introducción de Magrini, G. Turín: Einaudi.

Ginzburg, N. (1997). [1984]. La città e la casa. Turín: Einaudi.

Ginzburg, N. (1998). [1962]. Le piccole virtú. Scarpa, D. (Ed.). Turín: Einaudi.

Ginzburg, N. (2000). [1942]. La strada che va in città. Introducción de Garboli, C. Turín: Einaudi.

Ginzburg, N. (2001). [1973]. Caro Michele. Introducción de Garboli, C. Turín: Einaudi.

Ginzburg, N. (2002). [1970]. Mai devi domandarmi. Introducción de Garboli, C. Turín: Einaudi.

Ginzburg, N. (2011). [1977]. Famiglia. Scarpa, D. (ed.).Turín: Einaudi.

Ginzburg, N. (2014). [1963]. Lessico famigliare. Introducción de Segre, C. Turín: Einaudi.

Ginzburg, N. (2016). Un’assenza. Racconti, memorie, cronache. Scarpa, D. (Ed.). Turín: Einaudi.

lacoli, G. (2008). Un effetto como di prigione. Le case vulnerabili di Natalia Ginzburg. En Cretella, C. y Lorenzetti, S. (Eds.). Architetture Interiori. Immagini domestiche nella letteratura femminile del novecento italiano (pp.52-77). Florencia: Franco Cesati Editore. 
Marx, K. (2015). Manuscritos económico-filosóficos de 1844 (Trad. y notas Aren, F., Rotemberg, S. y Vedda, M.). Buenos Aires: Colihue.

Pflug, M. (2004). Natalia Ginzburg. Una biografia. Milán: La Tartaruga.

Sanvitale, F. (1986). I temi della narrativa di NG: uno specchio della società italiana. En Grignani $M$. A., Luti, G., Mauro, W., Sanvitale F. (Eds.). Natalia Ginzburg: la narratrice e i suoi testi (pp. 25-30). Urbino: La Nuova Italia scientifica.

Starobinski, J. (2012). L' inchiostro della malinconia (Trad. de Marchetti, M. Postfacio de Vidal, F.). Turín: Einaudi.

Surdich, L. (1995). "Da Natalia Levi a Natalia Ginzburg". En loli, G. (ed.). Natalia Ginzburg: la casa, la città, la storia. Atti del convegno internazionale San Salvatore Monferrato 14-15 maggio 1993 (pp. 5-27) S.S. Monferrato: edizioni della Biennale "Piemonte e Letteratura". 


\section{Gráfica de Atención Completa (G.A.C.), una propuesta metodológica educativa mediante proyectos interdisciplinares para el aprendizaje y mejora de la capacidad de atención-concentración a través del audiovisual y el arte}

\author{
Por: Lic. Francisco Cuéllar Santiago, Universidad de Granada, España, y \\ Dr. Isidro López- Aparicio Pérez, Universidad de Granada, España \\ Recibido: $\quad 25$ de setiembre, 2017. \\ Aceptado: $\quad 16$ de marzo, 2018
}

\section{RESUMEN}

La presente investigación examina los resultados de la puesta en práctica de una nueva metodología de enseñanza y aprendizaje denominada Gráfica de Atención Completa (G.A.C.), a partir de una investigación comparada (cuantitativa y cualitativa). Los participantes fueron alumnos de I.E.S. en la etapa de secundaria de las CC.AA. de Madrid $(I S I=20)$ y Murcia $(A C L=20)$. La introducción y el marco teórico encuadran la adaptación de la reciente Ley Orgánica sobre Educación (LOMCE) y su falta de atención a la cada vez más demandada alfabetización mediática. Además, se abarca una relación de las metodologías de aprendizaje emergentes desde una visión neurocientífica de la atención y se explican las bases narrativas audiovisuales utilizadas para la creación de esta metodología. Los datos cuantitativos han sido recogidos mediante cuestionarios previos al curso y otro posterior al concluir este, mientras que los datos cualitativos se han obtenido a través de la observación directa y el análisis de los trabajos realizados por los alumnos. Los resultados de la metodología muestran que la mayoría de los participantes ven beneficioso el uso de G.A.C. para la preparación de sus asignaturas, al encontrar un espacio creativo donde expresarse, además de un entorno acogedor de pertenencia con sus compañeros. Asimismo, remarcan que gracias a este método pueden ampliar su tiempo de concentración $30 \%$. Sin embargo, un cierto número de alumnos encuentran dificultad para aplicar la metodología al creer que no tenían habilidades suficientes para llevarla a cabo. La investigación acentúa en sus conclusiones, la necesidad de un trabajo profundo de los gobiernos para fomentar la alfabetización mediática en un contexto social cada vez más dependiente de las tecnologías y la comunicación.

\section{ABSTRACT}

\section{Complete Attention Graphic (G.A.C.), an Educational Methodological Proposal through Interdisciplinary Projects for Learning and Improving Attention-Concentration Capacity through Audiovisual and Art}

This research examines the results obtained in a testing course to analyze a new teaching and learning methodology called GAC (Graphic of Complete Attention), for

1 El profesor Francisco Cuéllar es licenciado en Comunicación Audiovisual, graduado del Centro de Educación Superior Felipe II de Aranjuez, centro adscrito a la Universidad Complutense de Madrid, y doctorando en el departamento de Dibujo e Historia del Arte de la Facultad de Bellas Artes, en la Universidad de Granada, España. Trabaja como profesor de esa misma Universidad, y como Coordinador y Creativo de la Editorial PuntodePapel en Madrid, España. Contacto: fcuellar@correo.ugr.es.

2 El profesor Isidro López-Aparicio es licenciado y doctor en Bellas Artes, graduado en la Universidad de Granada. Trabaja como profesor titular de esa misma casa de estudios. Contacto: isidro@ugr.es.
Francisco Cuéllar Santiago e Isidro LópezAparicio Pérez. Gráfica de Atención Completa (G.A.C.), una propuesta metodológica educativa mediante proyectos interdisciplinares para el aprendizaje y mejora de la capacidad de atención-concentración a través del audiovisual y el arte. Revista Comunicación. Año 39 , volumen 27 , número 1 , enero a junio, 2018. Instituto Tecnológico de Costa Rica. ISSN: 0379-3974 / e-ISSN1659-3820.

\section{PALABRAS CLAVE:}

Educación audiovisual, transversalidad, interdisciplinar, storytelling, videoarte, creatividad, alfabetización mediática.

KEY WORDS:

Media education, transversality, interdisciplinary, storytelling, video art, creativity, media literacy. 
which comparative research (quantitative and qualitative) was used. Participants in the course were secondary students from two schools in the region of Madrid (Secondary School San Isidro=20) and Murcia (High-Performing School in Lorca=20). Both the introduction and the theoretical framework encompass the updated Spanish General Law on Education (LOMCE) and its lack of consideration of the increasingly more necessary media literacy. This study also deals with the relationships between new teaching methodologies from a neuroscientific approach and explains the fundamental audiovisual narratives used for the proposed methodology.

Quantitative data has been gathered from questionnaires before and after the course, while qualitative data has been obtained from direct observation and the analysis of the students' works. The results of the methodology show that most of the participants benefited from the use of GAC when preparing their studies, since they find it a creative platform to express themselves. Results also highlight that this methodology enables students to increase their concentration span in $30 \%$. However, some students find it difficult to apply such methodology because they believe they do not possess the level of skills needed to accomplish it. This research concludes that the Government must make greater efforts in promoting media literacy, especially taking into account contemporary society's great dependency on technology and media.

\section{INTRODUCCIÓN}

La repercusión de la palabra "comunicación" para el año 2018 ha adquirido nuevas connotaciones que difieren sobremanera de las décadas anteriores. No se puede concebir una sociedad sin comunicación. No existiría el conocimiento humano si no se hubiese generado la palabra oral y escrita. Por ello, debe prestársele la suficiente atención para entender hacia dónde se dirige hoy el pensamiento humano y más concretamente, en el mundo de la educación.

En el año 2010 la UNESCO promulgó la Directiva Europea de Servicios Audiovisuales (Gavara de Cara y Pérez Tornero, 2012)), "en donde a través de diversos documentos oficiales, estudios y programas de acción, ha iniciado el camino de proveer indicadores para que la alfabetización mediática e informativa pueda ser evaluada" e insta a cada país a que pongan los medios necesarios para que sea un hecho. El camino recorrido hasta alcanzar este hito es largo y se remonta a la labor pionera que desempeñó la UNESCO entre 1982 (Declaración de Grunwald) y el 2000 (con un punto clave en el Seminario de Sevilla sobre Educación Mediática Seminario UNESCO sobre Educación en Medios-). El proceso tiene su tramo europeo final en la tarea llevada a cabo por la Comisión y el Parlamento entre el 2006 y el 2007, que culmina -precisamente-con la promulgación de la Directiva Europea de Servicios Audiovisuales, codificada en la actualidad en la Directiva 2010/13/UE del Parlamento Europeo y del Consejo del 10 de marzo de 2010, que unifica en un único texto la Directiva 2007/65/CE y la Directiva 89/552/CE.

En este sentido, España promulgó la Ley General de Comunicación Audiovisual para estar dentro del marco jurídico europeo (LGCA - Ley 7/2010 del 31 de marzo), pero desgraciadamente no ha ido más allá de su redacción, ya que no se creó el organismo o entidad correspondiente para el control y desarrollo de las actividades necesarias para una correcta alfabetización mediática. Asimismo y para ahondar más en la problemática, con la nueva Ley Orgánica para la Mejora de la Calidad Educativa (LOMCE) propuesta por el Partido Popular se reducen sobremanera las horas lectivas en términos de conocimiento audiovisual, artístico y musical.

Es aquí donde se situará esta investigación, para construir la explicación de este artículo que intenta demostrar cómo el audiovisual puede generar una nueva metodología de enseñanza-aprendizaje para el docente y discente, siendo una herramienta útil para el proceso de concentración durante el estudio.

Este trabajo intenta cubrir el vacío institucional, siguiendo unas pautas que ya se deben considerar intrínsecas a todo ser humano que haya crecido en lo que McLuhan (1972) definió como "Aldea Global".

\section{MARCO TEÓRICO}

Los medios técnicos cambian, la sociedad también lo hace y como tal, la educación debe reformarse. Así lo marca Acaso (2015) cuando dice "que la educación cambie, se adapte y evolucione 
Gráfica de Atención Completa (G.A.C.), una propuesta metodológica educativa mediante proyectos interdisciplinares para el aprendizaje y mejora de la capacidad de atención-concentración a través del audiovisual y el arte

paralelamente a la sociedad". Por lo que se hace necesaria una revolución educativa, como nombra la propia Acaso. Se trata de abandonar una pedagogía que se ha quedado estancada para caminar a una pedagogía actual y contemporánea. Para ello, Acaso defiende que se deben eliminar las fronteras entre las materias para generar proyectos interdisciplinares, ya que estos favorecen y enriquecen el aprendizaje. Siguiendo esta línea de pensamiento, se cree que la educación debe aproximarse a la afirmación de Robinson (2010), quien piensa que la educación debe equipararse al fluir de la vida, exponiendo que: "la educación se presenta como algo lineal, mientras la vida no lo es; ésta se muestra bajo un patrón orgánico".

Durante los últimos diez años ha crecido enormemente el interés por la alfabetización mediática, sobre todo desde la promulga de la UNESCO en el año 2010. Por eso, diferentes autores expresan que "dada la importancia de medios como la televisión, videojuegos o internet en la educación informal de los niños y jóvenes, sería impensable que la escuela permaneciese ajena a la influencia de los medios" (Gutiérrez, 2012). Así se generan nuevos términos referentes a la sociedad actual como el de "prosumidor" García-Ruiz, Ramírez-García y RodríguezRosell (2014), proponiendo que en la actualidad el "prosumidor" mediático produce y consume información "asumiendo un papel protagonista en el nuevo paradigma de la cultura participativa propiciado por la interactividad tecnológica", recogiendo las palabras de Sandoval y Aguaded (2012).

El 31 de marzo de 2010 salió publicada en el Boletín Oficial del Estado la Ley General de Comunicación Audiovisual en España (LGCA), la cual venía a ser la respuesta del Gobierno español en funciones (PSOE) a la petición del contexto normativo europeo en el ámbito de la alfabetización mediática, que "se ha formulado tradicionalmente como un objetivo de la política educativa y se entiende, en general, como una competencia a adquirir" (Gavara de Cara y Pérez, 2012). No obstante, la LGCA por sí sola no puede llegar a ser ejecutora de las actividades necesarias de control, gestión y proposición que le corresponde, por lo que se haría necesario crear un organismo regulador independiente a tal efecto. Fue en el año 2011 cuando se propuso la creación del Consejo Estatal de Medios Audiovisuales (CEMA). Además, se instó a la creación de organismos reguladores independientes de ámbito autonómico. Es importante entender la necesidad de un organismo como el CEMA, ya que desde algunos años atrás las sociedades han tendido a:

La apropiación de los medios -nuevos y antiguos- por parte de los usuarios: énfasis puesto en la actividad del receptor, en su capacidad de interacción y sus capacidades de apropiarse de los nuevos medios y servicios. Se está pasando de un régimen de difusión centralizada a un régimen de selección personalizada por parte del receptor donde las posibilidades de actuación de éste son constantemente potenciadas (Pérez Tornero, 2008).

Así, queda clara la importancia que conllevaría dentro del ámbito educativo, donde todos los alumnos son prosumidores de contenidos audiovisuales y conviven con toda la información que esto genera.

Ese mismo año, en el 2011, hubo un cambio de Gobierno en España con la entrada al poder del Partido Popular, lo que llevó a una serie de restricciones importantes en cuanto a la alfabetización mediática. La más importante de todas fue el anuncio de que no procedería la puesta en funcionamiento del CEMA y de forma velada, se anunciaría lo que posteriormente se llevó a cabo, atribuir a la Comisión del Mercado de las Telecomunicaciones (CMT) las competencias previstas en la LGCA. Esto significaba que se dejaba en manos del mercado todas aquellas prácticas que deberían ser neutrales, científicas y enfocadas a una alfabetización lo menos sectorizada posible; "pero lo más decisivo, sin duda, es la incidencia de esta suspensión en todo lo que se refiere a la protección de los derechos fundamentales" (Gavara de Cara y Pérez, 2012).

Debe tenerse presente que a nivel educativo, esta LGCA está diseñada para ser ejecutada desde una visión transversal en los planes de estudio. Sin embargo, al no constituirse el ya citado CEMA y darle el control al CMT, la regulación e imposición de los mecanismos vendrá marcado por el gobierno que ostente el poder de turno. Así lo 
ha venido demostrando el Partido Popular con la creación de la LOMCE, en donde se han reducido considerablemente las horas lectivas audiovisuales y su casi total desaparición de los planes de estudios. Gavara de Cara y Pérez (2012) apuntan que la alfabetización mediática, en lo que se refiere a los aspectos prácticos, debería afectar muchos campos: "desde la incorporación de la educación en medios, a la formación inicial y permanente de profesores -además de su inclusión en el currículo educativo básico" - (Gavara de Cara y Pérez, 2012), pero que con las imposiciones del nuevo Gobierno se han visto seriamente dañadas.

Tomando en cuenta este contexto español, vale hacer la siguiente pregunta: ¿qué tipo de población mediática se tiene hoy? Un joven que viva en un país desarrollado con los canales de comunicación habituales recibe de media entre una y cinco horas de consumo audiovisual, ya sea a través de Internet como de la televisión. Estos jóvenes que tengan una edad comprendida entre los 3 y los 17 años para el año 2018 tendrán una concepción completamente distinta de los condicionantes comunicativos que un adulto de 40 años que haya nacido a mediados de los años 70, ya que el propio lenguaje audiovisual ha incidido en su comportamiento y concentración a la hora de procesar la información. El exceso de datos y su velocidad de consumo consigue que la capacidad de atención del niño se haya visto reducido en $50 \%$ en relación con el siglo pasado, en donde se ha pasado de los 20 minutos de atención continuada a los 10 minutos actuales (TokuhamaEspinosa, 2011).

Ante esta bajada tan drástica en la capacidad de concentración, surgieron estudios e investigaciones que permiten al profesor educar de manera más eficiente en el aula, gracias a los avances científicos que la neurociencia está aportando a través de la tecnología de la imagen por resonancia del cerebro. Esta ciencia en gestación denominada Mind, Brain and Education (MBE) y que la Universidad de Harvard apoya con la creación de un máster específico con el mismo título, toma como objetivo elaborar un programa educativo brain-based, como lo describe José Antonio Marina en el prólogo del libro Neurociencia Educativa (Sousa, 2014).
En el 2012, Marina apuntaba que "en el 2002, la OCDE presentó un documento titulado Understanding the brain, en el que se afirmaba que la educación estaba aún en una etapa pre-científica, y que convenía preguntarse si las neurociencias podían ayudar a elevarla a un estatus científico". Por eso, un par de años después se constituyó la "International Mind, Brain, and Education Society" (IMBES), "con el objetivo de la creación de una ciencia transdisciplinar, construida sobre los conocimientos de la neurociencia, la psicología y la educación" (Marina, 2012).

Cinco años después de este cuestionamiento, Tokuhama-Espinosa, en su investigación para la OCDE 2014-2017 sobre neurociencia en educación, presentó una situación importante en cuanto a los cambios en los objetivos educativos generales se refiere, en los que detalló seis puntos fundamentales que han cambiado en la educación del siglo pasado y la época actual:

1. De "pasar clases" a ser un aprendiz a lo largo de la vida.

2. De recursos tradicionales de apoyo (textos) a la integración de la tecnología apropiada.

3. Del mejoramiento de uno mismo a un enfoque de colaboración, cooperación, comunicación, sensibilidad cultural y la construcción de comunidades en el contexto más amplio del grupo.

4. De la igualdad en acceso (todos asisten a la escuela) a la igualdad en calidad.

5. De poca información (pocos tienen acceso) a ser bombardeado por demasiada información (hay que aprender a discernir "buena" de "mala" información).

6. De enseñanza en silos (una materia separada de las otras) a la transdisciplinariedad.

Continúa apuntando que en la educación del siglo XXI se busca conseguir un alumno que sea pensador-crítico-creativo, gente con humildad intelectual, curiosidad y valentía intelectual. Se busca formar personas que sepan usar herramientas para resolver problemas, así como interactuar con grupos heterogéneos, es decir, personas autónomas 
Gráfica de Atención Completa (G.A.C.), una propuesta metodológica educativa mediante proyectos interdisciplinares para el aprendizaje y mejora de la capacidad de atención-concentración a través del audiovisual y el arte

que puedan enfrentar desafíos sin necesidad de que estén encima de ellos apuntando lo que tienen que hacer (Tokuhama-Espinosa, 2017).

Pero como punto base de este nuevo proceso de educación del siglo XXI, Tokuhama-Espinosa (2017) anota la idea fundamental para el docente: "si buscamos formar a personas de este tipo, nosotros (docentes) debemos tener todas esas cualidades". Por ello, lanza las siguientes preguntas a toda la comunidad docente: " $i$ Tenemos nosotros los conocimientos tecnológicos suficientes? ¿Somos capaces de manejar la complejidad? ¿Gozamos los problemas en lugar de buscar simples soluciones? ¿Tenemos un nivel de creatividad suficiente? ¿Somos innovadores? ¿Estamos auto-motivados?" (Tokuhama-Espinosa, 2017).

La concentración hoy es una lucha de poder por la masificación informativa y el bombardeo de datos diario. Es necesario captar la atención de los alumnos y para eso se debe utilizar el mismo código. La transdisciplinariedad e interdisciplinariedad, al igual que se utilizan en otros ámbitos del entretenimiento juvenil como pueden ser los videojuegos, móviles, Internet, audiovisuales, etc., son fundamentales.

No obstante, es importante dar una respuesta a la pregunta que lanzó Tokuhama-Espinosa (2017) y corroboró Marina (2017) "¿Cómo deberíamos dar clases para servir mejor al estudiante que aprende?". En este sentido, Guillén (2017) comenta que "una forma directa de suscitar la atención, un mecanismo imprescindible para el aprendizaje, es despertar la curiosidad, porque aunque a los seres humanos nos cueste reflexionar [...] somos curiosos por naturaleza" y para intentar dar una posible respuesta a esta pregunta y necesidad se ha desarrollado la presente investigación y metodología G.A.C.

\subsection{METOdOLOGÍAS DE ENSEÑANZA}

Antes de adentrarse en las bases de la metodología G.A.C., debe conocerse cuáles son las metodologías educativas que hoy están en boga y que los docentes deberían conocer y desarrollarlas, Ilegando a entremezclarlas para sacar el mayor potencial de cada una de ellas. Estas metodologías están funda- mentadas, como lo muestra Fortea (2009). Por lo tanto, para ajustar y otorgar de rigor a esta investigación se tiene que nombrar aquellas metodologías didácticas que han sido objeto de este estudio para crear la metodología G.A.C. e intentar explicar brevemente en qué consiste cada una. Además, se mencionará un caso particular de enseñanza global de centro: Las Comunidades de Aprendizaje (Flecha y Puigvert, 2002).

Las investigaciones sobre metodologías no pueden probar que unas sean mejores que otras, ya que los factores para considerar eficiente una metodología son muy variables y cada cual -a su modo- es válida para determinadas situaciones. Pero para su perfecta medición hay que tener en cuenta una serie de variables comunes a todas y que Fortea (2009) define como: "1. Resultados de aprendizaje u objetivos previstos; 2. Características del estudiante; 3 . Características del profesor; 4. Características de la materia a enseñar; 5. Condiciones físicas y materiales".

Con tal cantidad de variables sería muy laborioso definir un estándar general común a todas las metodologías, pero sí llegar a comprender que la ideal es aquella que combine varias de ellas. Se entiende desde esta visión que, para conseguir llegar a esta capacidad de unificación de metodologías, el docente debería conocer todas aquellas metodologías más innovadoras y saber utilizarlas. Pero se sabe que esto no ocurre habitualmente.

La web española Reallnfluencers (2017) ofrece una clasificación de metodologías que todo docente del siglo XXI debería conocer para defender sus clases con mayor garantía:

1. Flipped Classroom (Aula invertida): Los materiales educativos primarios son estudiados por los alumnos en casa y luego se trabajan en el aula.

2. Aprendizaje basado en proyectos (ABP): Permite a los alumnos adquirir conocimientos y competencias clave a través de la elaboración de proyectos que dan respuesta a problemas de la vida real. 
3. Aprendizaje cooperativo: Los alumnos trabajan en grupos de entre 3-6 personas, donde cada miembro tienen un rol determinado. Para alcanzar los objetivos es necesario interactuar y trabajar de forma coordinada.

4. Gamificación: La integración de mecánicas y dinámicas propias de juegos y videojuegos en entornos no lúdicos.

5. Aprendizaje basado en problemas: Proceso de aprendizaje cíclico compuesto de muchas etapas diferentes; preguntas que llevan a más preguntas en un ciclo creciente de complejidad.

6. Design Thinking: Consiste en una forma colaborativa de encontrar soluciones innovadoras y creativas a los problemas.

7. Aprendizaje basado en el pensamiento: Enseñarles a contextualizar, analizar, relaciones, argumentar... en definitiva, convertir información en conocimiento.

8. Aprendizaje basado en competencias: Representa un conjunto de estrategias para lograr el desarrollo de habilidades y solidificación de hábitos de trabajo.

9. Estándares de Núcleo Común (Common Core Standars, en inglés): Metodología enfocada para la enseñanza de las matemáticas y como bien explica la publicación digital denominada Revista Educación 3.0 (2016): “[...] Enseñan al alumno a razonar de manera abstracta para entender la forma en la que resuelven los problemas".

10. Método Singapur: Metodología enfocada en la enseñanza de las matemáticas, muy exitosa y con grandes resultados en los informes PISA de los últimos años. Según la publicación digital Educación 3.0 (2016): "Se conforma en base a tres conceptos: concreto, pictórico y abstracto".

Otro método que se cree importante y no aparece en la lista organizada por Realinfluencers es de Flecha García (2002) en donde el propio autor, junto a Puigvert, lo definen como:
[...] un proyecto de transformación de centros educativos dirigido a la superación del fracaso escolar y la eliminación de conflictos. Este proyecto se distingue por una apuesta por el aprendizaje dialógico mediante los grupos interactivos, donde el diálogo igualitario se convierte en un esfuerzo común para lograr la igualdad educativa de todas las alumnas y alumnos (p. 16).

El planteamiento pedagógico de las Comunidades de Aprendizaje utiliza como eje la posibilidad de favorecer el cambio social y disminuir las desigualdades, además de intentar que el contexto social y familiar se introduzca en el aula, transformando y llegando a la utopía educativa de todo el contexto educativo y social.

Todas estas propuestas son válidas en un contexto determinado y por supuesto, para un tipo de discente en concreto. Pero su funcionalidad puede verse mermada en otras situaciones diferentes. Por consiguiente y como ya se ha marcado, la metodología perfecta no existe. No obstante, si se consigue crear una que agrupe las características de una gran mayoría de ellas, es posible estar cerca de una globalizadora. Por lo tanto, con esta investigación se intentará elaborar una que aglutine propuestas de diferentes metodologías, con aspectos que se piensa son necesarios para la etapa de la educación secundaria. Para esto se propone una metodología didáctica que parte de la selección y análisis de un aprendizaje emocional, ayudado por técnicas utilizadas en el sector audiovisual y son de reconocido éxito en el mundo del cine y el marketing, basándose en la estructura del Mito Único de Joseph Campbell (1949).

\subsection{BASES NARRATIVAS AUDIOVISUALES DE LA METODOLOGÍA G.A.C.}

Para crear la metodología G.A.C. se diseña una linealidad de acciones en el transcurso de los 55 minutos de duración de una clase dentro de una asignatura dada, siguiendo un patrón de enseñanza aplicable a cualquier contenido de cualquier materia. En el proceso de creación de esa linealidad de acciones, el docente debe aportar su bagaje personal 
(emocional), donde aplique la impronta necesaria de su visión de los conocimientos que debe impartir.

La necesidad del aprendizaje en inteligencia emocional en cualquier etapa de la educación de un discente viene perfectamente definida por Goleman (1995 y 1996), anotando que esta inteligencia es "un conjunto de capacidades, competencias y habilidades no cognitivas que influyen en la habilidad propia de tener éxito al afrontar las demandas y presiones del medio ambiente y que implican emociones". Las emociones ayudan a crecer, a superar pruebas y además aprender a interactuar con el entorno.

Tanto el discente como el docente deben tener claro este aspecto, ya que como bien recuerda Campillo (2010):

Generalmente, cuando tenemos que recordar a nuestros mejores profesores, es decir, aquellos que más nos aportaron sobre todo beneficios, el 90\% de las cualidades que les solemos atribuir son de carácter socio-emocional: cercanía, confianza, credibilidad, capacidad para motivar, respeto, disponibilidad... Sólo un $10 \%$ de cualidades tienen carácter cognitivo-académico (explicaba muy bien, sabía mucho, era muy culta...).

Son las emociones y la memoria las que protegen en la vida de aquellas situaciones agraviosas que se han vivido, al igual que recuerdan aquellos buenos momentos que se quieren recordar por siempre. Estas emociones deben ir ligadas siempre a la educación, intentar generar sensaciones positivas, para que el aprendizaje así lo sea.

La "narratividad" es el pilar fundamental de esta metodología. Por lo tanto, se han tomado los puntos fundamentales de las estructuras audiovisuales para conformar una línea de tiempo, en la que el discente

Figura 1. La Estructura del Mito Único de Joseph Campbell

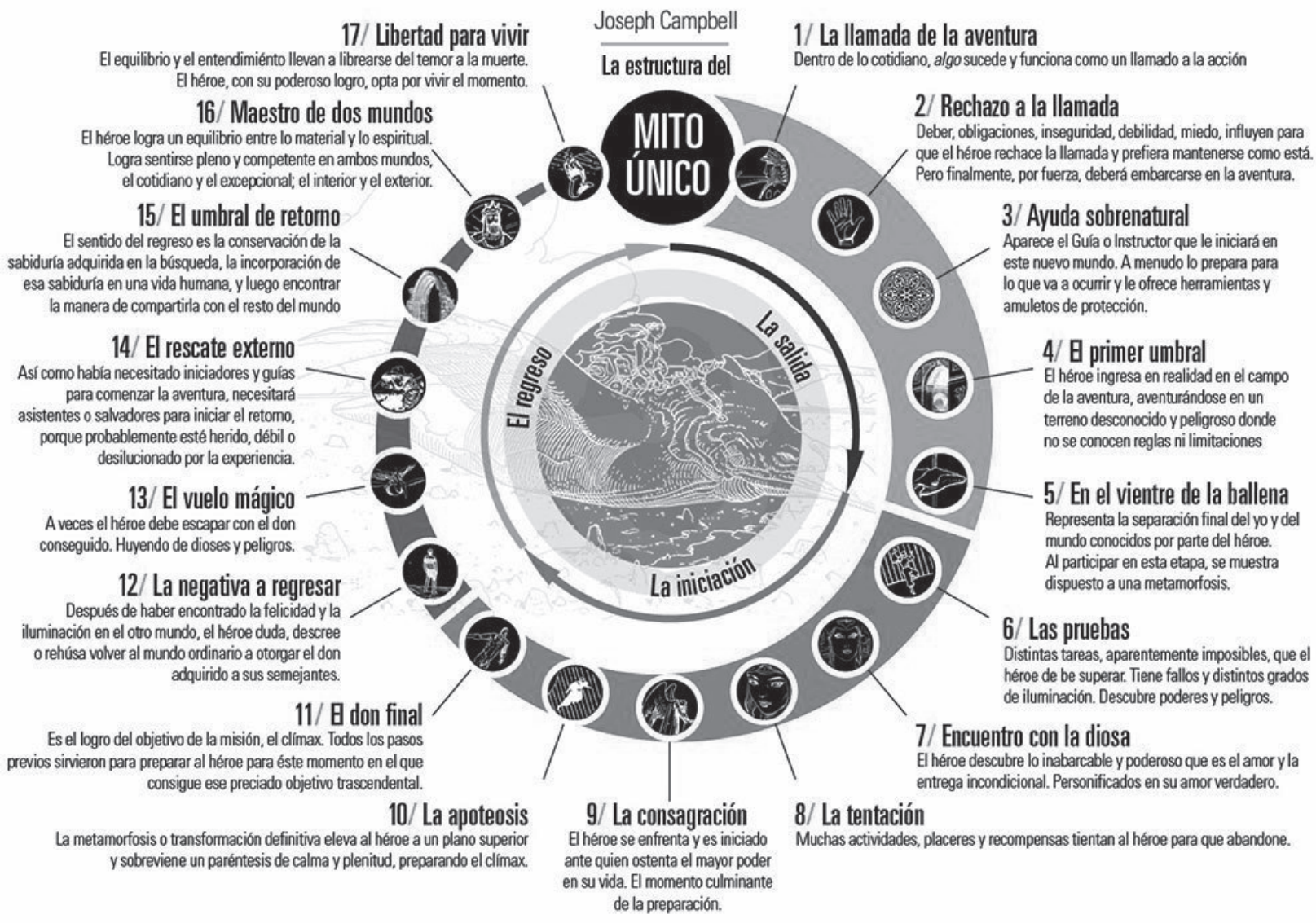

Fuente: Auchterlonie, 2014. 
recibirá los conocimientos que los planes de estudios marcan. El planteamiento metodológico-narrativo parte de la estructura narrativa de Vogler (2002) y Campbell (1949), en donde se exponen los doce estadios del viaje del héroe y que están expresados en la siguiente figura (Auchterlonie, 2014).

En relación con el Viaje del Héroe, concepto más actualizado que el de Campbell, es posible atender a su narración con base en el libro de Vogler y que describe la evolución del personaje de forma más sintética, agrupando los estadios en tres grandes fases (Introducción, Nudo y Desenlace), la cual sirve de punto de inicio para la metodología G.A.C. en cuanto a estructura temporal (Auchterlonie, 2014).

Figura 2. Línea temporal del Viaje del Héroe de Christopher Vogler

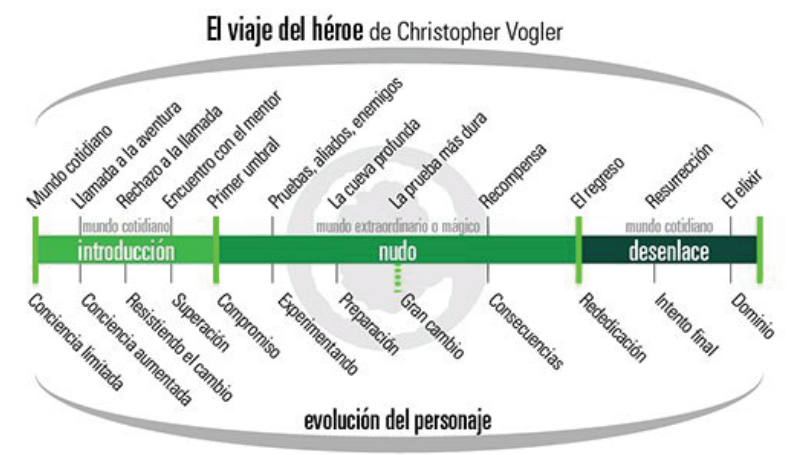

Fuente: Auchterlonie, 2014.

En la gráfica se puede leer la descripción de cada etapa, siguiendo un orden de espacios en los que el lector viaja haciendo valer sus experiencias y emociones. Toda la trama atraviesa tres fases: La Salida, la Iniciación y por último, el Regreso, en donde el protagonista debe hacer valer sus decisiones para atravesar todas y cada una de las etapas.

Tanto el Viaje del Héroe de Vogler como la Estructura del Mito Único de Campbell tienen una premisa común y es fundamental para la explicación de la investigación: la transformación o cambio del personaje, su evolución. Una historia no será considerada como una gran historia si su protagonista no sufre ese cambio, ese viaje que le convertirá en más sabio, fuerte o amado. La base del éxito es la evolución. Sánchez-Escalonilla (2009) dice al respecto: "[...] la transformación sí se produce en la intimidad del personaje, en su viaje interior, fruto de la nueva visión con que afrontará el mundo primario en lo sucesivo".

Hay que entender que las historias bien narradas alcanzan a un público mayor, atacando directamente las emociones y por lo tanto, permanecerá en el recuerdo del espectador durante más tiempo, consiguiendo que este se adentre en la propia historia.

\section{MATERIALES Y MÉTODOS}

\subsection{PARTICIPANTES}

Para el estudio se toman dos perfiles diferenciados de alumnos de dos comunidades autónomas de España. En los alumnos Tipo 1 se hace una selección multidimensional; es decir, alumnos de diferentes edades convivirán durante el curso. La selección de los alumnos se hace bajo una premisa abierta, dando opción libre a todos aquellos que quieran participar en la investigación, sin distinción por sexo, resultados académicos o motivación. Los alumnos Tipo 1 pertenecían al Instituto de Enseñanza Secundaria San Isidro de Madrid (Curso ISI denominado: Taller de videoarte y experiencia emocional. Curso 2015-2016), (código ISI) y se agrupó a discentes de todos los cursos de la etapa secundaria. Además, se permitió acceder a algunos de $1^{\circ}$ de Bachillerato, con un total de 20 alumnos. El número de alumnos por curso se determinó en: 4 de $1^{\circ} \mathrm{ESO}, 4$ de $2^{\circ}$ $\mathrm{ESO}, 5$ de $3^{\circ} \mathrm{ESO}, 4$ de $4^{\circ} \mathrm{ESO}$ y 3 de $1^{\circ}$ de BachiIlerato.

Para el Tipo 2 se decidió contar con discentes de una misma edad, pero con una diferencia más respecto al anterior grupo: trabajar en un contexto de alumnos de Altas Capacidades y así realizar una observación comparativa entre un grupo heterogéneo en cuanto a nivel de comprensión (Tipo 1) y un grupo homogéneo de alto rendimiento. Los alumnos Tipo 2 pertenecían a $3^{\circ}$ de la ESO de Altas Capacidades de Lorca y alrededores, en el Programa de Enriquecimiento Extracurricular de la Región de Murcia (Curso AC denominado: De las emociones al cine - Taller de Videoarte, 2016-2017 código ACL), con un total de 20 alumnos.

La duración del taller fue de seis meses en los dos casos, pero con una cronología diferenciada en 
Gráfica de Atención Completa (G.A.C.), una propuesta metodológica educativa mediante proyectos interdisciplinares para el aprendizaje y mejora de la capacidad de atención-concentración a través del audiovisual y el arte

cada caso: para el de ISI los talleres se realizaron cada semana con sesiones de 2 horas, mientras que para ACL las sesiones fueron de 3 horas cada quince días.

\subsection{DISEÑO}

Con lo explicado en el punto 2.2 surge el planteamiento principal de la investigación: hacer sentir al alumno que él es parte de la historia, parte de los contenidos que debe aprender y que sin su ayuda no podrá resolverse el conflicto: aprobar todas las asignaturas. Para ello se ha diseñado una Gráfica de Atención Completa (G.A.C.), la cual explica la importancia del ritmo y los puntos de giro dentro de una historia narrada.

Para el desarrollo del taller, obviamente se sigue el mismo método que se intenta demostrar. En su diseño se tuvieron en cuenta valores positivos de otras metodologías explicadas en el punto 2.1: escogiendo de Flipped Classroom las ventajas del trabajo audiovisual desde casa; de los $A B P$, realizar microproyectos que aglutinen la materia en diferentes fases; del Aprendizaje Cooperativo la importancia del trabajo en equipo; de la Gamificación, la integración de las estrategias audiovisuales de los videojuegos a la construcción de significación en la narratividad del aula; del Aprendizaje basado en problemas, saber ir resolviendo las preguntas que se van planteando en los estudios; del Design Thinking, la importancia de la innovación en cuanto a la resolución de los conflictos en las dinámicas; del Aprendizaje basado en el pensamiento, la necesidad de enseñar a contextualizar, analizar, relacionar y argumentar, y del Aprendizaje basado en competencias, la adquisición de las habilidades necesarias para superar las competencias que se marcan en los planes.

Como método de estudio y elaboración, se han seguido las bases planteadas y bien conocidas por los docentes del aprendizaje significativo de Ausubel (1963) la cual más tarde sufriría una parcial modificación (Ausubel, Novak y Hanesian, 1978), en donde explica la clave de la teoría del aprendizaje significativo en contraposición con el aprendizaje memorístico con una serie de requerimientos clasificados en:
1. Materiales de aprendizaje significativo.

2. Una disposición por parte de la persona que aprende a enlazar cada concepto del nuevo material con conceptos que ya tiene.

3. Una estructura cognitiva relevante o apropiada en el alumno, es decir, que algunos conceptos de esta puedan ser relacionados, de manera no arbitraria, con los nuevos conceptos. Según González García (1992):

(...) la cumplimentación de estas condiciones, desde un punto de vista didáctico/ metodológico, parece fundamental, pues implica, de una parte, el conocimiento de la estructura cognitiva del alumno, de otra, la planificación adecuada del currículo y la instrucción y, finalmente, el fomento de actitudes favorables a este tipo de aprendizaje, con el potencial de motivación necesario.

Además, el autor marca los mapas conceptuales diseñados por Novak y basados en la teoría del aprendizaje de Ausubel-Novak (Ausubel, Novak y Hanesian, 1978) como la perfecta metodología para implementar el aprendizaje significativo en el aula y señala que:

En la mayor parte de los programas escolares, es frecuente que los alumnos memoricen mecánicamente definiciones o normas de procedimiento sin relacionar los significados de las palabras de las definiciones o de las normas con las ideas que ellos ya comprenden. En realidad, los alumnos llegan a creer que la memorización de la información escolar es la única forma de aprender (p. 54).

Por lo tanto, es muy importante hacer ver a los discentes que otra forma de aprender es posible y que los docentes tienen que mostrarles el camino y para que eso realmente se logre, dice González García (1992), es necesario que los alumnos incrementen su conocimiento en: "1. El proceso de aprendizaje, 2. La naturaleza del conocimiento y 3. Cómo extraer significados de los materiales estudiados". 
Asimismo, afirma González García, (1992): “El mapa conceptual puede ser considerado como una representación visual de la jerarquía y las relaciones entre conceptos contenidas en la mente". Por eso se marca dentro de la metodología G.A.C. con tanta importancia la relación del dibujo con el aprendizaje. Será la creación y comprensión de ideogramas las que ayuden a los discentes a elaborar sus propias herramientas de estudio. Para Stewart, Kirk y Rowell (1979), el mapa conceptual es un instrumento para representar la estructura conceptual de una disciplina o segmento de una disciplina, en dos dimensiones. Por consiguiente, los ideogramas son la mejor manera de crear aprendizaje significativo a través de su propia bidimensionalidad. Un ideograma, según la Real Academia de la Lengua Española (RAE), "es una imagen convencional o símbolo que en la escritura de ciertas lenguas significa una palabra, morfema o frase determinados, sin representar cada una de sus sílabas o fonemas". Estos ideogramas deben ser pensados y dibujados por el alumno a través de la conceptualización de los contenidos a estudiar y su inclusión dentro de la propia historia por narrar.

\subsection{INTERVENCIONES}

En la primera jornada del taller se les entrega a los alumnos unos cuestionarios en los que se analizan los procesos de desarrollo y comprensión respecto a su percepción personal del entorno educativo. Se sigue un proceso de preguntas que evoluciona de lo más general hasta las preguntas más concretas y se busca que el alumno demuestre su capacidad de abstracción por medio del dibujo y la expresión escrita. Por lo tanto, se usan cuestiones abiertas y cerradas dicotómicas, y cuestiones cerradas categorizadas de respuesta sugerida. En el cuestionario diseñado se pueden medir las dimensiones de los conceptos-objetivos de esta investigación (metodología de trabajo, metodología de estudio, estructura mental y por último, sentimiento de pertenencia).

El cuestionario cuenta con 24 ítems, de los cuales, siete son de tipo abierto y 17 de tipo cerrado. Las dimensiones por medir corresponden en un porcentaje de $15 \%$ al tipo de alumno según sus calificaciones, otro $15 \%$ a las creencias respecto a sus capacidades, en $20 \%$ se midieron las dimensiones referentes a la autonomía en relación con las asignaturas, con otro $10 \%$ las metodologías que siguen para estudiar y con $10 \%$ su entorno de aprendizaje; con otro $10 \%$ la capacidad de abstracción conceptual con base en el dibujo y la palabra, y por último, un $20 \%$ midió los sentimientos de inclusión hacia sus compañeros y su centro educativo por medio del sentimiento de orgullo o vergüenza.

En la aplicación de los conocimientos adquiridos por parte del alumno conviene destacar la importancia del arte contemporáneo, el cual sirve de nexo relacional de conceptos a través de las emociones a los elementos cotidianos. Con la muestra de diferentes piezas video-artísticas de importantes creadores audiovisuales (tales como Bill Viola, Chris Marker y Nam June Paik, entre otros), se clasifican previamente a la enseñanza de la metodología G.A.C. una tipología de emociones, que servirán de punto de partida en donde encontrar empatías de trabajo. Se cree que estas empatías emocionales crearán un recuerdo más fiel en el alumno de las piezas audiovisuales mostradas y así tener un recurso al que recurrir a la hora de trabajar sus propios trabajos audiovisuales.

La metodología para el alumno debía ser igual para todos, en la que se diseñaron los siguientes pasos (Tabla 1): 
Gráfica de Atención Completa (G.A.C.), una propuesta metodológica educativa mediante proyectos interdisciplinares para el aprendizaje y mejora de la capacidad de atención-concentración a través del audiovisual y el arte

Tabla 1: Pasos de la metodología

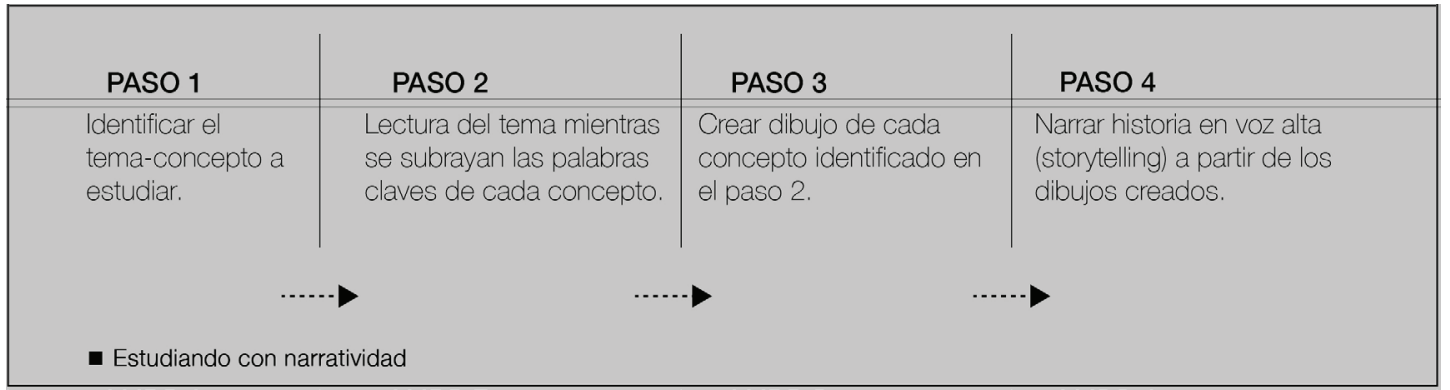

Fuente: elaboración propia

Cada paso de la metodología llevaba implícito un alto grado de diálogo, en el que el docente da margen suficiente al discente para considerar el aula como un espacio de interactuación acogedor.

Se explicó un concepto que hoy es relevante en el mundo audiovisual y empresarial, y del que este trabajo se ha apropiado para las dinámicas: storytelling, el cual Vizcaíno (2016) lo ha definido dentro del marco publicitario como "la instrumentalización de la innata habilidad humana de narrar, a tra- vés del uso de historias con un fin determinado". Se cree firmemente que las historias contadas mediante las emociones con una buena base visual, ayudarán a los alumnos a recibir más eficientemente los contenidos y trabajar de esta manera la inteligencia emocional para crear su propio espacio de pertenencia en el aula.

Para la investigación se siguió el siguiente procedimiento de estudio (Tabla 2):

Tabla 2

División de las jornadas del taller tanto para ISI como ACL

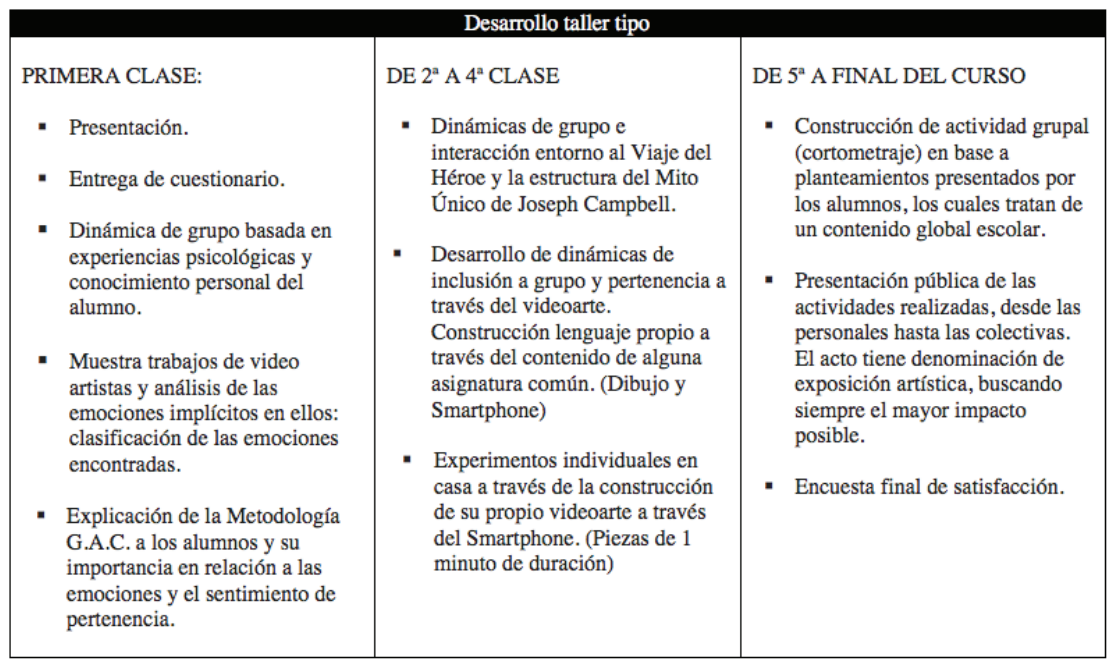

Fuente: elaboración propia

A partir de estos elementos se diseña una nueva gráfica, partiendo de las reglas del Viaje del Héroe de Vogler, donde el alumno será el héroe y tendrá que viajar en cada clase por los contenidos hasta alcan- zar el éxito. Para esto será llevado de la mano del docente, que actuará -como lo denominó Campbell. De esta forma se configura una Gráfica de Atención Completa reflejada en la figura 3. 
Figura 3. La línea de puntos discontinua refleja la curva de atención de la audiencia en una charla de 45 minutos sin elementos de bidireccionalidad.

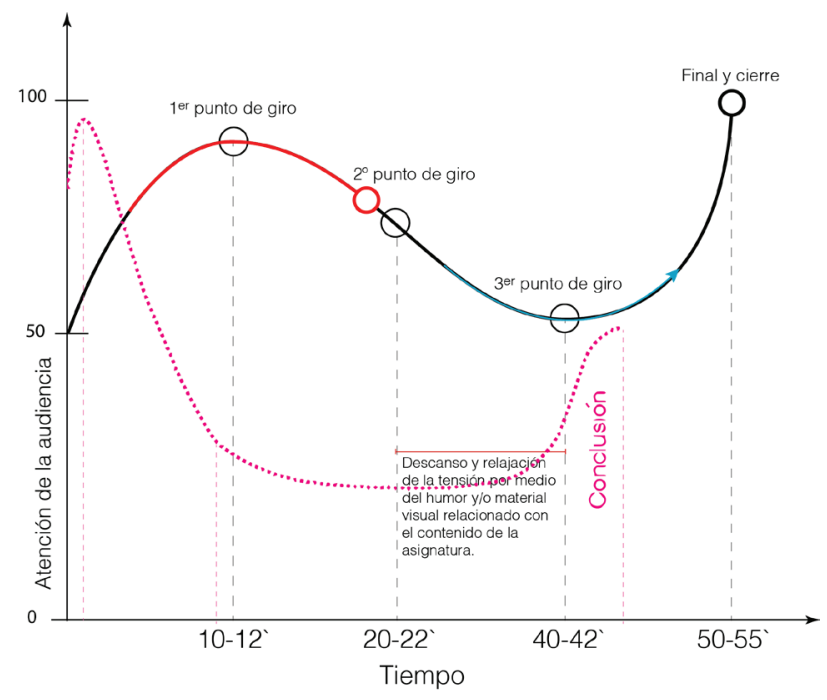

Fuente: Muñoz (2010)

Se define el concepto de Plot Point para que el alumno entienda la importancia de los giros. Debido a esto, se hace uso de la matización de Kristin Thompson (1999): “Un plot point es un evento o acontecimiento que engancha la historia y la hace girar en otra dirección" y añade en su libro que se decanta por el término turning point -punto de inflexión-, "ya que implica un evento crucial o cambio, mientras que un plot point simplemente parece implicar un evento significativo que podría o no crear una transición mayor". Entonces, estos incidentes o eventos son los que hay que definir previamente en relación con el contenido global a impartir, que serán tomados como lugares donde mostrar elementos audiovisuales, gráficos o performativos. El alumno viajará por todos los estadios marcados en la explicación, llevado por el ritmo de la historia por contar.

La historia comienza en un punto determinado donde a los discentes se les considerará neutrales, partiendo de una información base que servirá de anclaje. Poco a poco hay que subir la intensidad y el ritmo hasta alcanzar el primer punto de giro, el cual debe ser un concepto importante de la enseñanza de esa sesión. Este punto de giro deberá venir cargado de dinámicas para el alumno, ya sea por medio de recursos gráficos o actividades. Seguidamente se descenderá la intensidad, creando un ambiente de trabajo óptimo para la asimilación del contenido. A mitad de la G.A.C. se comprueba que hay un descenso en la concentración. Esto es muy importante para volver a captar la atención, ya que -utilizando las premisas del Viaje del Héroeel protagonista tiene que cruzar la Cueva profunda, adentrándose en la prueba más dura que le debilitará sobremanera, pero obtendrá una Recompensa, para posteriormente llegar al Regreso. Es en este punto donde con gran impulso debe llegar hasta el final de la historia (clase). En la gráfica se añade el estudio de Muñoz (2010), donde muestra la gráfica de atención para una conferencia de 45 minutos sin bidireccionalidad; así el lector podrá comprar las diferencias de ritmos e intensidades.

El siguiente paso para comprender la metodología de G.A.C. fue la asimilación de la narratividad. La actividad consiste en definir un contenido específico de alguna asignatura en la que el discente tenga dificultad para aprender y aprobar. Una vez definido el contenido a investigar, el alumno debe disponer los planteamientos necesarios para crear su propio storytelling. El dibujo (ideograma) debe ser el pilar fundamental a la hora de construir su narrativa.

Para explicar la importancia del dibujo, Ainsworth y Russell (2011) han señalado que "realizar visualizaciones es esencial para el pensamiento científiCo" y además que "los investigadores no sólo usan palabras sino que también se apoyan en diagramas, gráficos, vídeos, fotografías y otras imágenes para hacer descubrimientos". Es por esto que no se debe olvidar que tener destreza a la hora de conceptualizar ideas y pensamientos en dibujos más o menos abstractos es fundamental para el buen desarrollo del intelecto.

Una vez que el discente tiene centrados los conceptos, debe proceder a realizar la síntesis del storytelling, siendo capaz de narrar su propio viaje del héroe en los términos de la asignatura de estudio. En la figura 4 se ve un ejemplo de storytelling realizado por el alumno ISI16, en relación con la asignatura de francés: 
Figura 4. Imagen tomada de la exposición en clase del alumno ISI16 de su storytelling

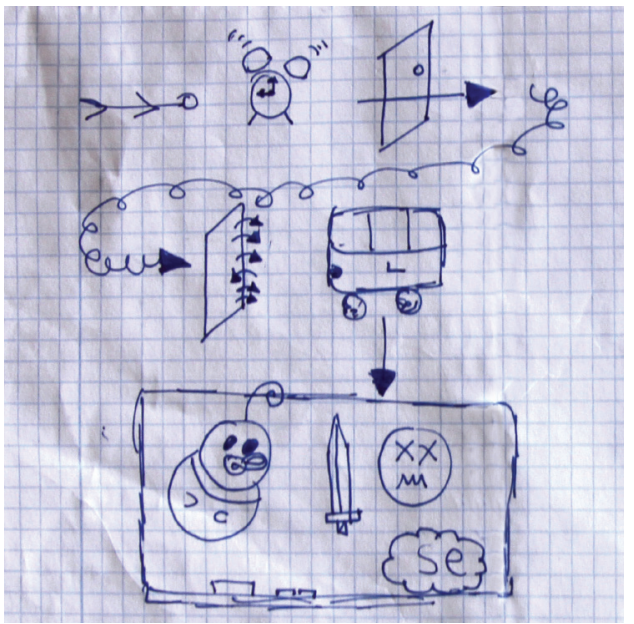

En su exposición en el aula, marcó los pasos de todo el temario que debía preparar para un próximo examen y señaló que la síntesis de los conceptos en ideogramas le sirvió para recordar todos los puntos por desarrollar el día de la prueba. Explicación transcrita de ISI16:

El primer "dibujo" es un hombre/mujer tumbad@. Haciendo una referencia a "tomber". (Porque está tumbado). La segunda es "rester" (porque cuando suena una alarma quieres quedarte, rester, un poco más). La tercera es "passer" (pasar por la puerta). La cuarta es "retourner" (ir hacia el salón). La quinta son varios verbos que son de ir $y$ venir: aller, entrer, venir, arriver, sortir. (haciendo que vas adentro y afuera porque se olvidan cosas y hay que volver) La sexta es un autobús "monter" (porque voy en autobús todos los días al instituto) La séptima es "descendre". (porque desciendes del bus y llegas al instituto). La octava es una pizarra porque damos historia ese día y nos enseñan la vida de una persona: nace "naître", le hacen caballero "devenir" y por último muere: mourir". Son de la familia "se" (para hacer "se revellier" por ejemplo).

El siguiente paso en la investigación es la creación de microvideos (videoartes) por parte de los alumnos de no más de 1 minuto, donde plasman las emociones que sienten en relación con las asignaturas que cursan. Además, los contenidos deben interactuar con la materia que han seleccionado/estudiado para la metodología. Tras poner en común todas las emociones y explicar brevemente los motivos de su elección, se hace una comparativa con los trabajos de videoartistas mostrados en clases anteriores, analizando los métodos de enseñanza de las emociones aplicados por ellos y los propios artistas. De esta forma, se afianzan los conceptos narrativos de expresión emocional, intentando alcanzar de esta manera un discurso propio.

Se continúa con el trabajo grupal, donde se desarroIla en concepto de temática libre un cortometraje común, de entre 5 y 15 minutos, y que debe seguir los pasos marcados anteriormente con el Viaje del Héroe de Vogler. Así, se construye una trama cerrada en el que se ejemplifica un personaje y su evolución, hasta conseguir construir una historia completa. Una vez diseñado y escrito el guion literario y técnico desarrollado por los alumnos, se pasa al rodaje de este, el cual se divide en 3 o 5 sesiones.

Para la exposición final, los alumnos serán parte del equipo técnico y artístico del evento, donde se permitirá el acceso a familiares y alumnos para visionar los trabajos realizados.

Figuras 5, 6 y 7. Exposición final taller ACL el día de la presentación. La figura 5 pertenece a momentos previos al inicio, la figura 6 a la entrada de padres al evento, mientras que la figura 7 pertenece a la presentación de un videoarte.
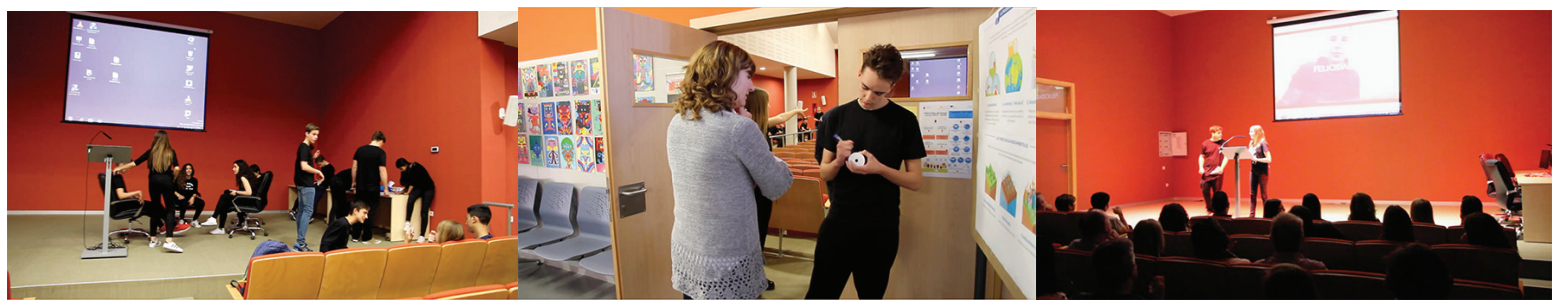

Fuente: elaboración propia 


\subsection{ANÁLISIS}

Para el estudio de la investigación se ha seguido el procedimiento de la Teoría Fundamentada, concretamente un análisis comparativo utilizando el método de Glaser y Strauss (Andréu y Pérez, 2007) el cual permite descubrir aquellos aspectos que son relevantes de una determinada área de estudio (Strauss y Corbin, 1990). Con este modelo, se busca una mejor comprensión de los datos obtenidos de la observación de los talleres, los datos recabados mediante las piezas audiovisuales realizadas por los alumnos y las respuestas vertidas por estos en los cuestionarios con preguntas abiertas y cerradas que se plantearon, tanto al inicio como al final del taller.

Con los datos obtenidos de los cuestionarios iniciales $(\mathrm{Cl})$ rellenados por los alumnos del ISI y $\mathrm{ACL}$, fue posible realizar el análisis para su clasificación, de la cual se dará cuenta en el apartado de resultados.
Ahora, el estudio se centrará en explicar el análisis cualitativo que se ha elaborado con la Guía de Observación (GdO), Ilevada a cabo a lo largo de los seis meses de taller, tanto del ISI como de ACL. La GdO evalúa al alumno desde tres ángulos diferenciados: a) exposición en el encerado del aula de su metodología G.A.C. desarrollada a través del contenido de la materia elegida, b) la participación en clase a lo largo del taller y la realización de las dinámicas planteadas por el docente y c) exposición y explicación del videoarte realizado. Los datos fueron recogidos gracias a la observación directa, utilizando unos ítems preestablecidos en una tabla, creada a partir de la Guía de Observación para la Detección de Necesidades Educativas propuesta por el Consejo Nacional de Fomento Educativo de México (Pública, 2010) y que fue adaptada para los discentes españoles. Dicha guía adaptada constaba de las siguientes dimensiones:

Tabla 3

Dimensiones GdO G.A.C.

TESIS DOCTORAL FRANCISCO CUÉLLAR SANTIAGO

METODOLOGIA G.A.C. LA EDUCACIÓN AUDIOVISUAL. UNA INVESTIGACIÓN DE INTERACCIÓN INTERDISCIPLINAR EN LAS ARTES AUDIOVISUALES Y SU RELACIÓN EN EL ENTORNO EDUCATIVO.

\author{
Secundaria \\ Indicadores de observación en secundaria \\ Ámbito Cognoscitivo. \\ 1. Se distrae fácilmente y pierde el interés y la atención en clases. \\ 2. Se fatiga con rapidez y no mantiene su atención por un periodo prolongado. \\ 3. Muchas veces no puede realizar la actividad solo; necesita de asesoria \\ directa. \\ 4. Necesita que le repitan una instrucción varias veces para poder comprenderla. \\ 5. Deja incompletos sus trabajos escolares. \\ 6. Presenta dificultades significativas en la escritura. \\ 7. Manifiesta dificultades significativas en la lectura. \\ 8. Muestra dificultades significativas en la comprensión de textos. \\ 9. Experimenta dificultades para acceder a nuevos contenidos. \\ 10. Presenta dificultades para transmitir un mensaje con claridad y darse a entender. \\ 11. Sus diálogos son cortos y algunos sin sentido. \\ 12. Al redactar un texto libre, lo hace con gran dificultad y poca claridad. \\ Ámbito Psicomotor. \\ 1. Enfrenta dificultad para tomar de manera adecuada el lápiz, los colores, un cuaderno, etcétera. \\ 2. Presenta dificultades para los trabajos manuales. \\ Ámbito Psicosocial. \\ 1. Con frecuencia cambia de estado de ánimo durante un mismo dia: de estar muy contento a muy enojado o triste. \\ 2. Se enoja con facilidad; incluso puede llegar hasta los golpes. \\ 3. Le cuesta trabajo adaptarse a cualquier situación de convivencia. \\ 4. Se relaciona muy poco o nada con sus compañeros. \\ 5. No respeta reglas. \\ 6. Es reservado al manifestar sus sentimientos, y muy poco expresivo. \\ 7. Con frecuencia actúa sin pensar, de forma impulsiva. \\ 8. Muestra comportamientos agresivos. \\ 9. La mayor parte del tiempo se le ve desmotivado para realizar cualquier actividad.
}

Fuente: elaboración propia 
La selección de las dimensiones preparadas para la investigación de este artículo han seguido un proceso de criba con respecto a los propuestos por el CONAFE.

Los datos recogidos mediante la observación se analizaron en dos fases: una primera para los contenidos teóricos, dinámicas y exposición de cada alumno, y una segunda recogida de datos durante el proceso de grabación del cortometraje y los videoartes. Para recabar los datos, se usó el método híbrido propuesto por Álvarez y Jurgüenson (Álvarez, 2003), en el que se utilizaron algunas herramientas de tipo cuantitativo dentro de una investigación cualitativa.

Los indicadores cognoscitivos están centrados en todos aquellos aspectos referentes a la concentración, atención y capacidad del alumno para el estudio. Por su parte, los indicadores psicomotores se centran en los aspectos físicos del discente y sus capacidades motoras y de destrezas. Por último, los indicadores psicosociales miden los aspectos relacionales del alumno con su entorno educativo, ya sean docentes o compañeros. Cada apartado cuenta con distintos indicadores de observación del alumno, que fueron evaluados individualmente día a día en dos fases diferenciadas, una inicial (primeras dos semanas de taller) y otra final (última semana de taller) donde poder realizar de esta manera una comparativa de evolución. Para concluir el análisis, se les solicitó a los alumnos que rellenasen unos cuestionarios finales de satisfacción (CF).

\section{RESULTADOS}

De la primera fase de investigación se obtuvo de los $\mathrm{Cl}$ una clasificación de los alumnos dividida en cuatro estadios, los cuales sirvieron para mostrar especial atención en aquellos que denotaban mayor dificultad para adquirir los conocimientos necesarios (Tabla 4).

Tabla 4: Tipología de alumnos obtenidos de los cuestionarios iniciales

\begin{tabular}{|c|c|c|c|}
\hline $\begin{array}{l}\text { Tipo1. Alumnos } \\
\text { altamente autónomos y } \\
\text { con gran capacidad de } \\
\text { abstracción simbólica, } \\
\text { con alto sentimiento de } \\
\text { pertenencia al centro } \\
\text { escolar y hacia sus } \\
\text { compañeros. }\end{array}$ & $\begin{array}{l}\text { Tipo 2. Alumnos con } \\
\text { necesidades de atención } \\
\text { pero lo suficientemente } \\
\text { autónomos como para } \\
\text { sacar provecho de los } \\
\text { estudios. Nivel } \\
\text { intermedio de } \\
\text { abstracción simbólica } \\
\text { pero con alta capacidad } \\
\text { psicomotriz (destreza). } \\
\text { Poseen un amplio } \\
\text { sentimiento de } \\
\text { pertenencia hacia sus } \\
\text { compañeros pero no tan } \\
\text { alto hacia el centro } \\
\text { escolar. }\end{array}$ & $\begin{array}{l}\text { Tipo 3. Alumnos con } \\
\text { necesidades de atención } \\
\text { y concentración pero alta } \\
\text { capacidad para los } \\
\text { trabajos de destreza } \\
\text { manual. Nivel bajo de } \\
\text { abstracción simbólica. } \\
\text { Bajo sentimiento de } \\
\text { pertenencia en cualquier } \\
\text { ámbito. }\end{array}$ & $\begin{array}{l}\text { Tipo 4. Alumnos con } \\
\text { bajas capacidades de } \\
\text { atención y concentración } \\
\text { y bajas capacidades en } \\
\text { destreza. El sentimiento } \\
\text { de pertenencia al centro } \\
\text { y a los compañeros } \\
\text { apenas existe. }\end{array}$ \\
\hline
\end{tabular}

Fuente: elaboración propia

Esta tipología es global y generalizadora para los dos grupos de discentes observados. Pero debe anotarse que en el grupo ACL, el porcentaje de alumnos Tipo 1 fueron los predominantes; en $80 \%$ y en $20 \%$ los Tipo 2, mientras que los Tipos 3 y 4 no obtuvieron ningún resultado. En el grupo ISI -por su parteel porcentaje estuvo más repartido entre el resto de tipologías, siendo la predominante los Tipos 2 y 3, dejando en minoría a los Tipos 1 y 4 (véase figura 8). 
Figura 8. Tipologías de los alumnos investigados y su porcentaje

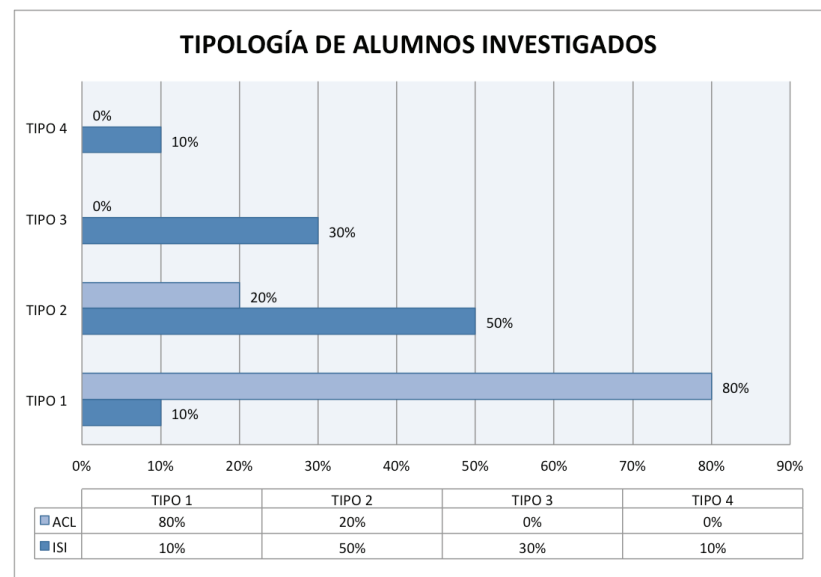

Fuente: elaboración propia

Una vez clasificados los alumnos por su tipología, se deben ofrecer los resultados de las tipologías de emociones que fueron clasificadas por estos en las primeras sesiones tras el visionado de los videoartes. Estas emociones son las que los discentes posteriormente trabajaron en sus propias piezas audiovisuales. De la observación y exposición de los alumnos se consiguió la siguiente clasificación de emociones y el porcentaje de uso en sus trabajos audiovisuales (figuras 9 y 10):

Figura 9. Emociones trabajadas por ACL Lorca.

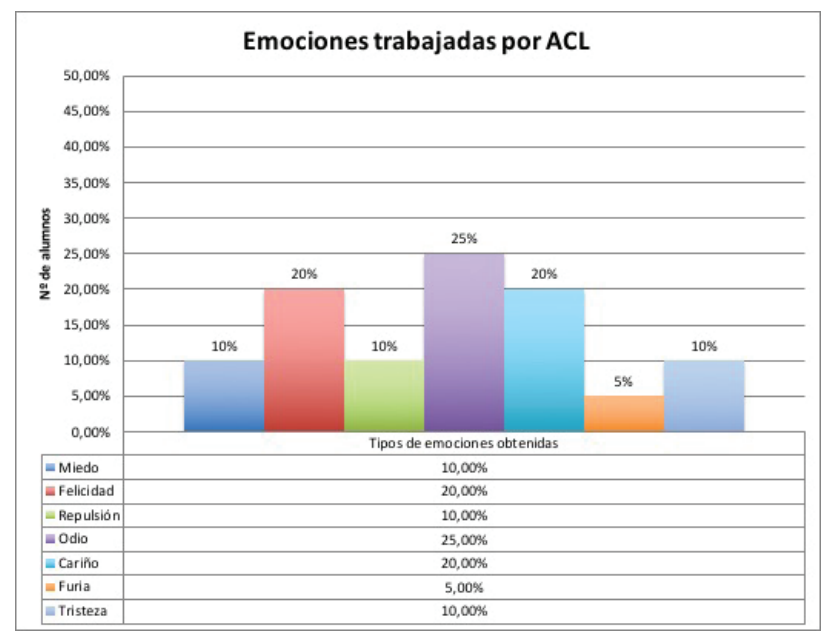

Fuente: elaboración propia
Figura 10. Emociones trabajadas por ISI Madrid

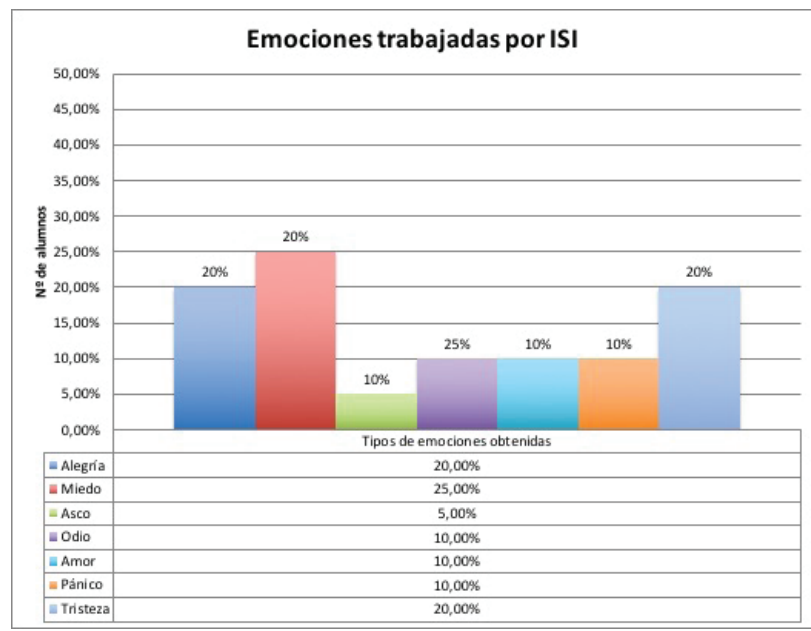

Los resultados de las emociones expuestas por los alumnos fueron comparadas con las que Goleman (1996) clasificó en el año 1996 y que sirvió para que los discentes entendieran la importancia de las emociones en el entorno diario, tanto laboral como personal. La clasificación que Goleman propuso se resumía en dos grandes apartados donde incluirlas. Por un lado, estarían las emociones básicas o primarias, que vienen marcadas por una expresión facial. Existe cierta polémica para llegar a un entendimiento en su clasificación, pero normalmente se suele usar la de alegría, tristeza, miedo, asco e ira. Por otro lado, se tendrían las emociones secundarias o complejas, ya que surgen de las primarias y no presentan expresiones faciales, como pueden ser satisfacción, pena, terror, repulsión o furia, respectivamente.

Como ya se ha explicado en el apartado 3.3 de esta investigación, el Cl diseñado tenía cuatro fases de análisis (método de trabajo, estudio, estructura mental y sentimiento de pertenencia) y era importante investigar el nivel de abstracción de los alumnos en cuanto a su relación con los ideogramas que deberían desarrollar posteriormente dentro de G.A.C. Así que -tras analizar los $\mathrm{Cl}$ - se observó que aquellos alumnos con alta capacidad en el ámbito de estructura mental, al preguntárseles "¿Por norma general sueles memorizar conceptos en base a imágenes o en base a palabras?" mostraron en $75 \%$ una capacidad de abstracción simbólica de la imagen muy baja, siendo mayor en los aspectos de palabra. 
En cambio, los alumnos de ISI obtuvieron un 65\% de mayor grado de relación con la imagen que con la palabra, el cual obtuvo 35\% del total, como se puede observar en las figuras 11 y 12 .

En relación directa con la cuestión planteada de palabra e imagen, se les solicitaba a los alumnos un pequeño ejercicio de interpretación de una imagen dada, a modo de pregunta abierta de la que se podría obtener un dato más fiable de la cuestión anterior (figura 13).

Figuras 11 y 12. Respuestas Cl19, tanto de ISI como de ACL
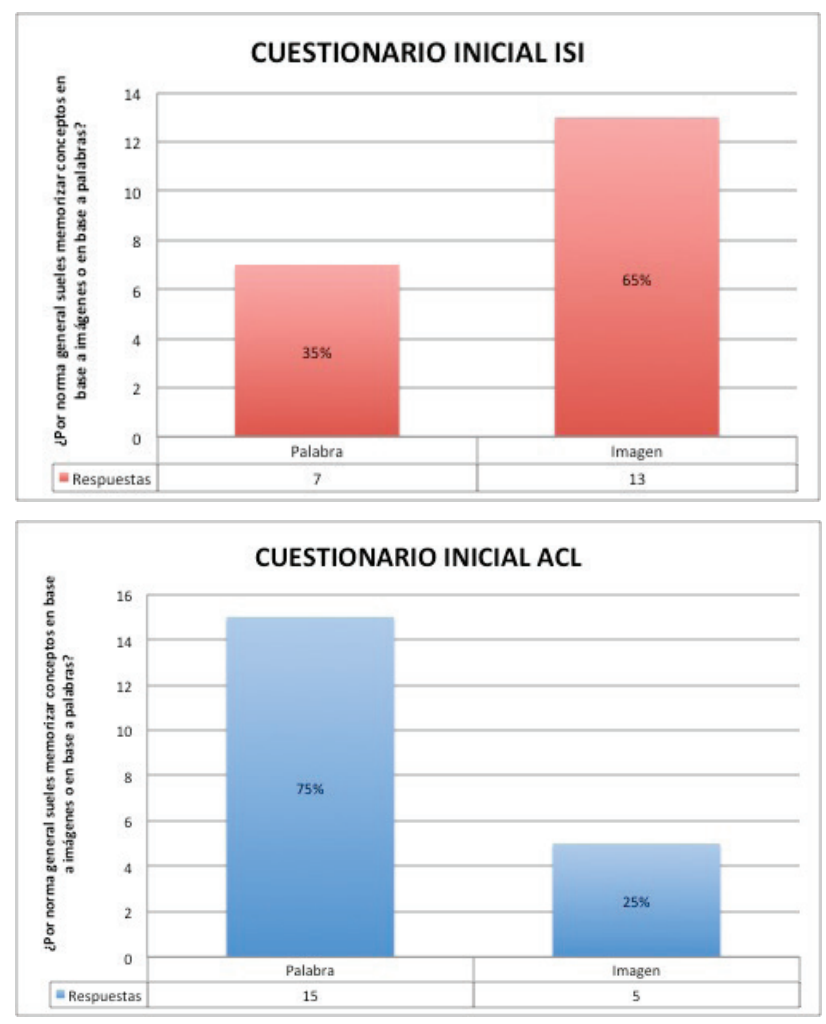

Fuente: elaboración propia

Figura 13. Respuesta alumno ISI14 en relación con la pregunta CI20 del cuestionario. Fotografía tomada del cuestionario original

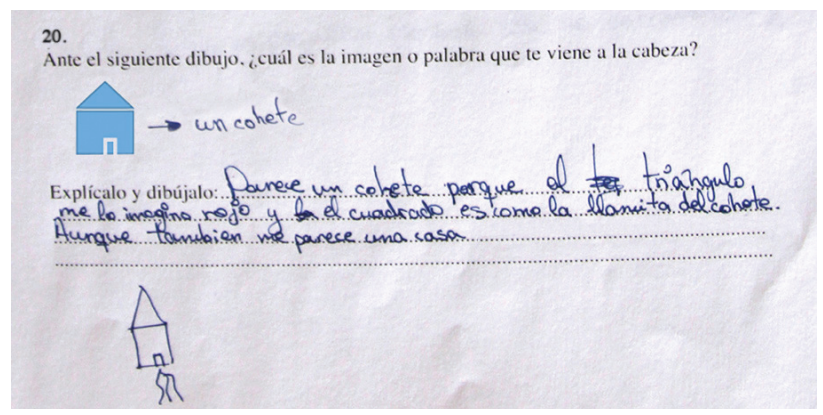

Los resultados de la primera fase de GdO denotaron unos datos esclarecedores con respecto a las carencias de concentración y atención de los alumnos de ISI en contraposición con los de ACL, situación que se invierte cuando se habla de los datos de cuestiones psicomotrices y psicosociales. En relación con las dimensiones cognoscitivas de inicio y final del taller se observa que las capacidades de atención y fatiga se ven reducidas en $30 \%$ en los dos casos de estudio, gracias al uso de G.A.C., al igual ocurre con los valores de fatiga y comprensión, en donde los márgenes de mejoría se han visto superados en $20 \%$ en los dos casos.

Los alumnos de ACL denotaron gran mejoría en la medición 5 de la GdO Cognoscitiva, al tener un porcentaje de mejoría del $15 \%$ respecto a la medición inicial. Vale anotar que en las mediciones realizadas en ISI respecto a los apartados 6 y 7 en cuanto a la lectoescritura no se observan grandes mejorías (figuras 14 y 15).

Figura 14. GdO Cognoscitivo ISI

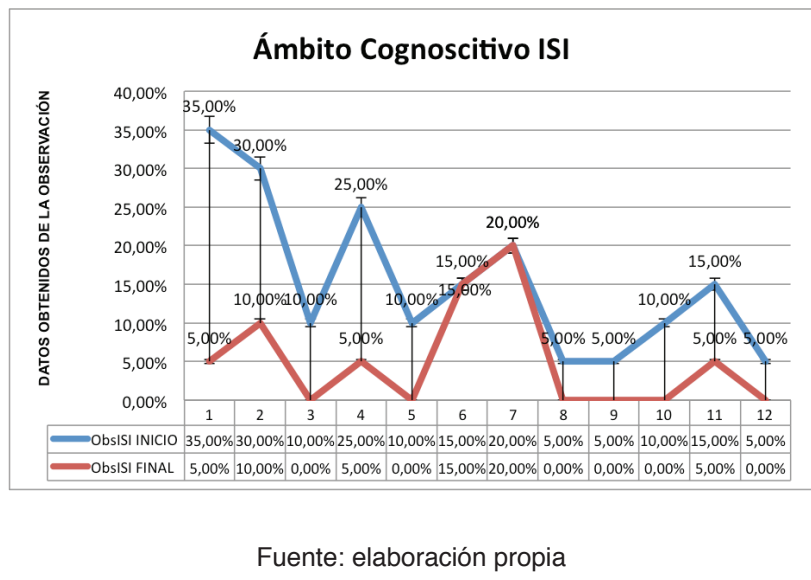

Figura 15. GdO Cognoscitivo ACL

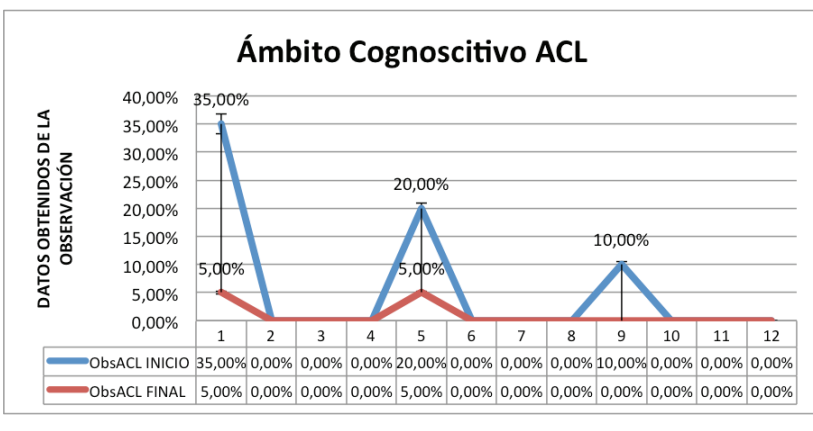

Fuente: elaboración propia 
En cuanto a los aspectos psicomotrices, los alumnos ven aumentadas significativamente sus capacidades gracias a los aspectos manuales de la realización de las dinámicas "El cine en tu cabeza", "Realización de videoarte personal" y el "Cortometraje grupal", en donde los discentes debían construir las escenografías y vestuarios, además del manejo de todos los equipos técnicos de un rodaje, como pueden ser los equipos de iluminación, sonido, producción y cámara (figuras 16 y 17). Se evidenció que dos alumnos de ACL poseían cierta dificultad a la hora de sostener con destreza los utensilios, a lo que se le intentó hacer ver su error para corregirlo. Pero el exceso de costumbre del alumno y la falta de tiempo necesario por parte de los docentes para una completa atención hizo imposible su mejoría.

Figura 16. GdO Psicomotor ACL

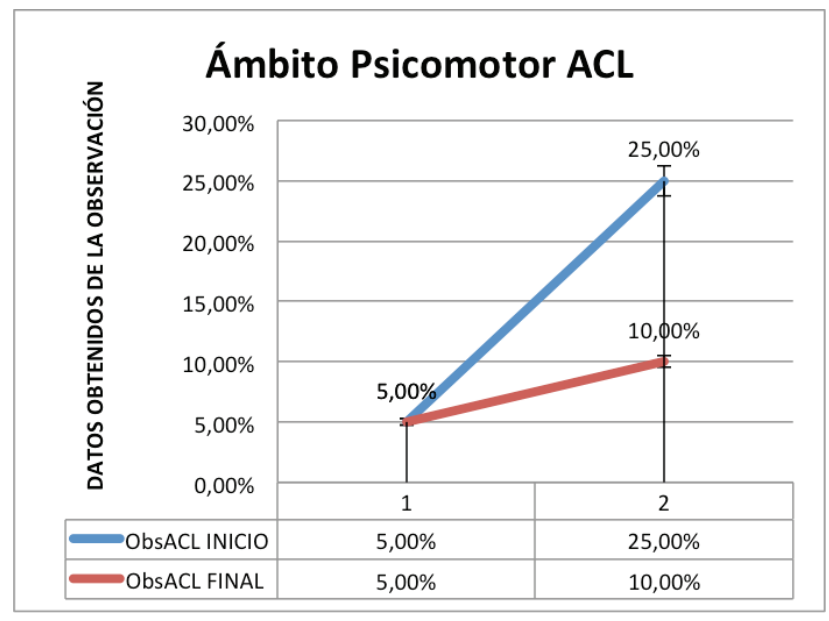

Fuente: elaboración propia

Figura 17. GdO Psicomotor ISI

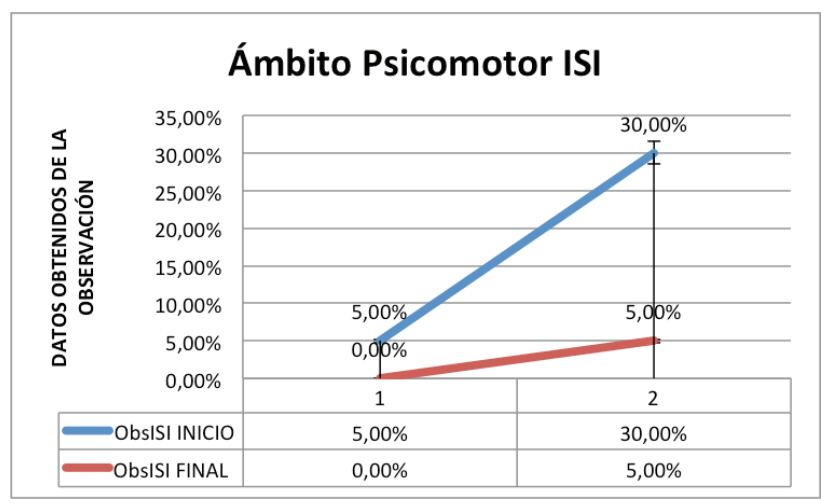

Fuente: elaboración propia
Con respecto al análisis de las mediciones psicosociales, se tiene que anotar que uno de los valores fundamentales del audiovisual es el trabajo en equipo, sin el cual sería imposible la realización de cualquier pieza compleja. Por eso se hizo especial hincapié en este sentido, sobre todo en el grupo ISI, donde se observó en un inicio a dos alumnos con muy baja capacidad de empatía y sentimiento de pertenencia, debido a una situación personal complicada. Durante las semanas siguientes se pudo ver que los alumnos poco a poco entraban en las dinámicas con mayor soltura y entendimiento con el resto de sus compañeros. Así se mostraron grandes mejorías en aspectos como la medición núm. 4, en donde las relaciones entre iguales dentro del grupo mejoraron $30 \%$. Al igual ocurrió con la motivación a la hora de realizar las actividades, donde en 25\% se vieron incrementados los estímulos hacia las dinámicas. Más dificultades se encontraron a la hora de mostrar los sentimientos, donde el nivel de mejoría fue más bajo, tan solo de $10 \%$. Al respecto de los estados de ánimo, las mejorías también fueron moderadas, siendo un reflejo común en discentes de estas edades.

En cuanto al grupo de ACL, se vio que sus aptitudes sociales de empatía también reflejaban una carencia importante, además de las referentes al trabajo en equipo, situación que se agravaba por la desmotivación que este tipo de alumnos suele sentir en ciertos momentos ante las carencias de estímulos. Gracias a las dinámicas pudieron ir entrando en los grupos, creando sus propias filias entre compañeros. Así queda reflejado en la medición núm. 9, donde la mejoría fue de $40 \%$ entre los alumnos, creando un buen ambiente en las dinámicas grupales. Situación importante de mejoría se vivió en cuanto a la expresión de los sentimientos (medición núm. 6), donde alumnos cuya expresividad emocional en un inicio fue muy baja consiguieron manifestar situaciones personales importantes en la dinámica de videoarte, expresando emociones abiertamente a todos sus compañeros. Además, esta situación ayudó a que los estados de ánimo cambiantes habituales entre discentes jóvenes (medición núm. 1) se vieran visiblemente mejorados, gracias a tener un mayor conocimiento de los compañeros y de sus sentimientos hacia situaciones comunes (figuras 18 y 19 ). 
Figura 18. GdO Psicosocial ISI

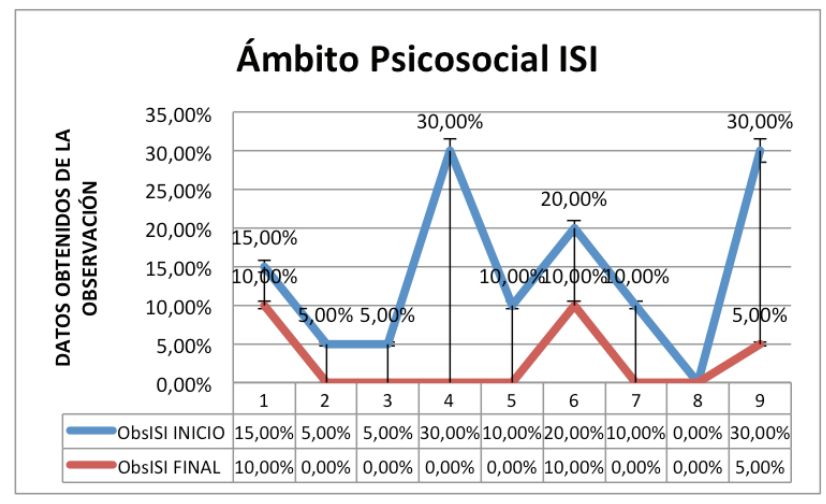

Fuente: elaboración propia

Figura 19. GdO Psicosocial ACL

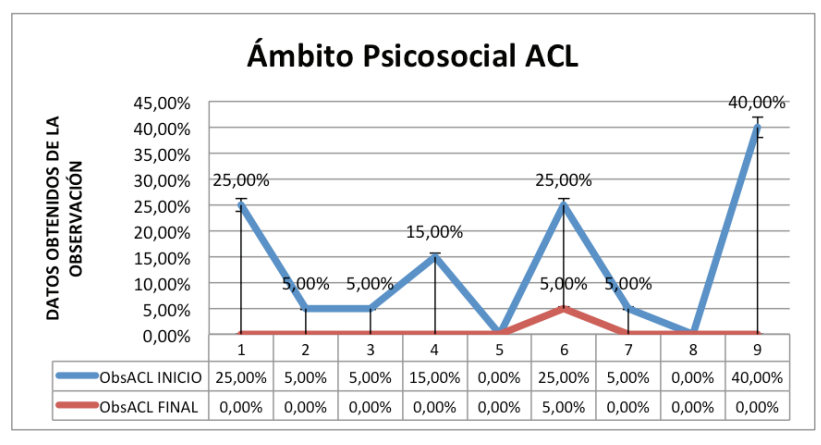

Fuente: elaboración propia

En el cuestionario final (CF), a los alumnos participantes de ISI y ACL el último mes del curso lectivo, se les preguntó si les sirvió como método de estudio en sus asignaturas el aprendizaje de la metodología G.A.C. y la respuesta fue mayoritariamente positiva, como se puede comprobar en la figura 20. Se anota que $25 \%$ de los alumnos no hicieron uso de la G.A.C. tras acabar el taller, justificando que les resultaba complicado dibujar, teniendo un alto sentimiento de frustración en este factor. Además, esos mismos alumnos que no hicieron uso de la metodología argumentaban una falta de motivación para esto, debido a la frustración artística.

Con el CF se quiso ver la respuesta de los alumnos a cuestiones planteadas en el $\mathrm{Cl}$ y observar si se producían cambios en su manera de entender las diferentes fases de análisis planteadas. Así, se comprobaron diferencias notables en cuanto a los métodos de trabajo, en donde $70 \%$ de los alumnos de ISI y $60 \%$ de los alumnos de ACL cambiaron de opinión al considerar más beneficiosos para ellos trabajar plasmando sus ideas propias y poder dirigir con tareas abiertas los trabajos a realizar. Además, los alumnos de ISI y ACL valoraron con $80 \%$ que se les daban mejor las tareas donde había que experimentar y manipular, cuando en el $\mathrm{Cl}$ marcaron otras opciones.

Figura 20. Uso de la G.A.C. por los alumnos participantes

\section{USO GAC AL CONCLUIR EL TALLER}

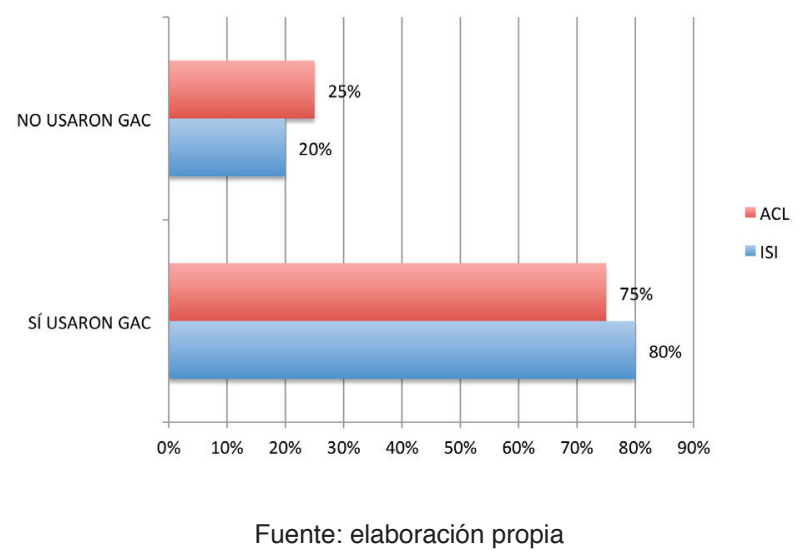

En cuanto a los métodos de estudio, los alumnos apoyaron mayoritariamente el uso de herramientas artísticas para sus estudios, complementando la lectura y la escritura, creyendo que sería beneficioso para una mejor comprensión de la asignatura.

Fue importante observar cómo discentes que -anteriormente habían marcado que nunca habían relacionado contenidos de otras asignaturas con la que estaban estudiando- habían comenzado a realizarlo consiguiendo una visión más global de los contenidos. El porcentaje de alumnos que así lo realizaron fue de $30 \%$ en el caso de ISI y $40 \%$ en el de ACL. Además, 90\% de alumnos tanto de ISI como de ACL contestaron que tras utilizar G.A.C. siguieron haciendo uso de los mapas mentales para el estudio de los temas de las asignaturas.

En relación con el sentimiento de pertenencia, afirmaron en los dos equipos de trabajo con 100\% que, tras la utilización de la metodología, se había creado un clima apropiado para el aprendizaje. Del mismo modo, aseguraron que se sentían orgullosos del grupo que se había formado. 


\section{CONCLUSIONES Y DISCUSIÓN}

La intervención de la metodología G.A.C. muestra una nueva herramienta para el profesorado, capaz de generar mayor atención y motivación al discente, entroncando directamente con las emociones, aportando un bagaje personal y emocional a los alumnos que disfrutarán unas clases donde saber explayarse, expandiendo sus conocimientos más allá de los reglados en los planes de estudio. El docente entiende el aula como un espacio escénico, donde poder narrar y disfrutar el arte de la interpretación, mostrando los conocimientos por medio de herramientas técnicas audiovisuales, plásticas o performativas y que lleven al alumno a través de las emociones del contenido educativo. Los resultados experimentales en la investigación cualitativa desarrollada muestran que los alumnos prefieren este tipo de métodos en comparación con el tradicional método de lección magistral propuesta por Brown y Atkins (Brown y Atkins, 1988).

Los alumnos han consolidado sus conocimientos en relación con las materias mostradas en las actividades G.A.C. realizadas. Como ya se ha marcado en la figura 16, son muchos los alumnos que han continuado usando G.A.C. tras finalizar su aprendizaje en el taller, y han mostrado gran satisfacción en su uso. La investigación continuará el próximo curso, analizando a los alumnos que ya han aprendido la metodología para intentar obtener datos referentes a su uso a largo plazo. Se intentará recabar información de las posibles mutaciones de la propia metodología G.A.C. por los propios alumnos -ya que esta metodología tiene un planteamiento vivo, el cual está abierto a cambios en cualquiera de sus ámbitos- y poder de esta manera crecer a modo de mapa conceptual con el tiempo.

Los datos cualitativos recogidos por parte de los alumnos han sido realmente satisfactorios. Se nombrará el caso del alumno ACL05 que, tras el aprendizaje metodológico G.A.C. y llegar a entender la técnica, lo llevó a la práctica en su propio ejercicio de videoarte, en donde desarrolló una síntesis gráfica formidable, con una analogía relacional de amor y muerte que todos los compañeros aplaudieron (figura 21).
Figura 21. Videoarte ACL05. Ejercicio grabado con Smartphone. Duración: 1 minuto

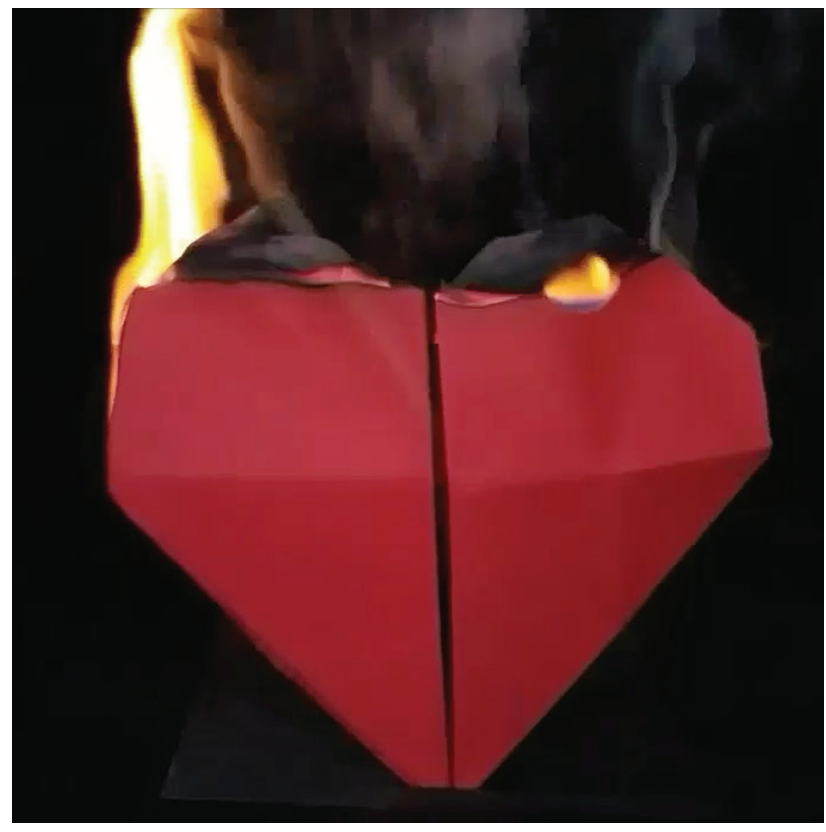

Desde el primer día de clase las emociones forman parte fundamental de todos los contenidos. Se intentan argumentar con historias narradas repletas de alegorías emocionales audiovisuales para introducir la alfabetización audiovisual. De esta manera, los alumnos tendrán vía libre para explicar sus sentimientos sin necesidad de hablar en primera persona, y mostrar estados psicológicos empáticos que ayuden al sentimiento de pertenencia por medio de sus compañeros. Este hecho fue patente en el CF a través de las mediciones CF24.1 y CF24.2, en donde alumnos como ISI02 reflejaron el sentimiento de pertenencia hacia sus compañeros y la satisfacción que ello le produjo (figura 22): 
Gráfica de Atención Completa (G.A.C.), una propuesta metodológica educativa mediante proyectos interdisciplinares para el aprendizaje y mejora de la capacidad de atención-concentración a través del audiovisual y el arte

Figura 22. Cuestionario alumno ISI02.

24.1

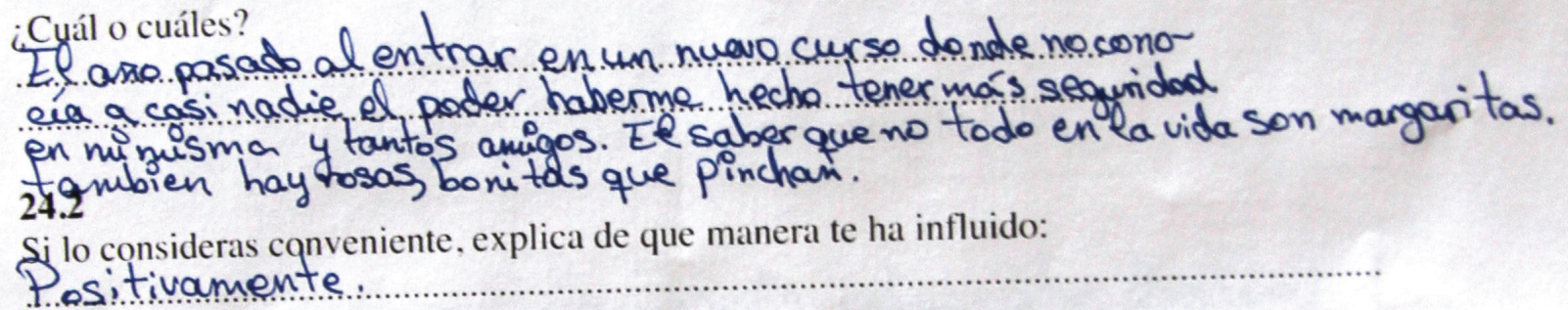

Por lo tanto, el sentimiento de pertenencia es casi tan importante como saber leer. Un alumno motivado siempre será un alumno aventajado en cuanto a esfuerzo, sabrá dosificar sus competencias y complementarse con el resto de sus compañeros, de modo que podrá desarrollar la habilidad de trabajar en equipo.

Cada alumno es único y sus motivaciones son distintas. El aprendizaje es múltiple y como tal, debe ofrecerse una visión múltiple de la educación para diseñar un nuevo modo de pensar en el discente. Así lo señalan en la entrada de su blog Arina Bokas y Rod Roca (Bokas, 2015), Cambiar el modo de pensar en Educación: cada alumno es único, publicada en The Huffington Post, sección de Educación. Las columnistas se basan en la investigación de Carol Dweck y hacen referencia a la teoría de las inteligencias múltiples de Howard Gardner para diseñar modos de pensar sobre el éxito en la educación, en un intento de conseguir una mayor potenciación de las habilidades de los estudiantes.

Esta metodología de trabajo, tanto para el profesor como para el alumno, requiere un esfuerzo ciertamente alto en sus primeras fases, en donde será necesario crear técnicas de creatividad. La metodología G.A.C. es una buena herramienta, capaz de aglutinar esa creatividad, conocimiento y diversión, y permitirá tanto al alumno como al profesor crear su propio discurso. La cultura debe circular en todos los sentidos, entretejiéndose a través de las asignaturas y desarrollar de esta forma lo que debería ser la base de toda educación escolar: la Interdisciplinariedad.
Por consiguiente, se sabe que para poder considerarla como una metodología global necesita tiempo, además de docentes que se atrevan a llevarla a cabo, apostando por los medios audiovisuales y sus posibilidades narrativas, permitiendo al alumno disfrutar de aulas dinámicas. Se entiende que las necesidades técnicas son en muchas ocasiones un obstáculo para muchos centros, pero con creatividad es posible suplir las técnicas, ya que las grabaciones hoy son más sencillas gracias a los teléfonos inteligentes. Para que G.A.C. funcione es importante que el docente adquiera esos conocimientos narrativos que se han expresado en la investigación y llegue a disfrutar la oratoria. Sin estos conceptos, será imposible conseguir que un alumno se emocione ante sus palabras.

Es importante anotar las carencias observadas de la metodología G.A.C., siendo conscientes de los pobres resultados en cuanto a lectoescritura, cuyo aspecto debe ser mejorado para los futuros cursos de puesta en práctica e investigación de la metodología. Son la escritura como la comprensión lectora dos puntos básicos para concebir buenos argumentarios y exposiciones de la materia a estudiar. Será interesante aunar fuerzas con otras metodologías cuyos resultados sean positivos en este ámbito y crear nuevas dinámicas que solucionen esta carencia.

Por otro lado, habrá que definir más dinámicas de trabajo individuales dentro del aula para poder abarcar el mayor número de asignaturas posibles. Es entendible que algunas asignaturas son más proclives al uso de ideogramas que otras y por eso, se debe preparar un mayor número de supuestos esce- 
narios a los que los discentes se puedan enfrentar en su etapa educativa.

Los datos de la investigación indican que la necesidad de alfabetización mediática es toda una realidad. Los alumnos piensan en imágenes, sueñan en imágenes y viven en imágenes. Han interiorizado todo el argumentario audiovisual dentro del devenir de sus acontecimientos diarios. Por lo tanto, la educación no puede vivir al margen. Se tiene que educar en y con el audiovisual.

Los alumnos se sienten cómodos dentro de contextos audiovisuales, saben expresarse y encontrar los argumentos necesarios para relacionarse con sus compañeros, así lo demuestran los datos de esta investigación. Son ellos los primeros en introducir nuevos conceptos audiovisuales a sus hábitos diarios. Los docentes deben ser parte de ellos.

Los profesores que están activos actualmente son los que han crecido con la televisión e Internet dentro de sus hogares. Pero también han conocido la etapa justamente anterior. En consecuencia, son los primeros en tener la necesidad de alfabetización, aprenderla y saber mostrarla.

Sin embargo, con la tan intrusiva LOMCE no se está dejando margen a los docentes para crear conocimientos en esta línea. Por lo tanto, se hace más necesario aún introducir la alfabetización mediática por otras vías dentro del sistema educativo y G.A.C. puede ser una herramienta adecuada a tal efecto.

Pero deberán ser los gobiernos en funciones los que realicen los cambios necesarios en sus Leyes de Educación, para que la alfabetización mediática sea un hecho. Hay que hacer ver a la sociedad que esta problemática puede convertirse en un asunto de gravedad, con la tan creciente manipulación mediática que se vive en los últimos años. Los medios de comunicación son conscientes de su poder y los poderes políticos no dudan en controlar aqueIlas vías de comunicación que permitan manipular a sus votantes. Es por eso que las personas deben estar preparadas ante toda la avalancha informativa que reciben, siendo además, las personas partícipes de ella, en cierta medida, gracias a plataformas como Twitter. La alfabetización mediática es una verdadera necesidad.

\section{REFERENCIAS}

Acaso, M. (2015). rEDUvolution. Hacer la revolución en la educación. Barcelona: Ediciones Paidós Ibérica.

Ainsworth, S. P., V. y Russel, T. (2011). Drawing to learn in science. Science. 333(6046), 10961097.

Álvarez, J. L. (2003). Cómo hacer investigación cualitativa, fundamentos y metodología. México D.F. : Editorial Paidós Mexicana S.A.

Andréu, J. G., A.; Pérez, A. M. (2007). Evolución de la teoría fundamentada como técnica de análisis cualitativo. Cuadernos Metodológicos $N^{\circ}$ 40.

Auchterlonie, T. (2014). El viaje del héroe: el argumento eterno [Gráfico]. Recuperado de http:// escrilia.com/el-viaje-del-heroe-el-argumentoeterno/.

Ausubel, D. (1963). The Psychology of Meaningful Verbal Learning. New York: Grune y Stratton.

Ausubel, D., Novak, D. y Hanesian, H. (1978). Educational Psychology: A Cognitive View. New York: Holt, Rinehart y Winston.

Bokas, A. (2015). Cambiar el modo de pensar de educación: cada alumno es único. Recuperado de http:/translate.google.com/translate?dep th $=1 \& \mathrm{hl}=$ es \&prev=search \&rurl=translate.google.es\&sl=en\&u=http://www.huffingtonpost. com/smart-parents/changing-the-mindset-ofe_b_7445856.html.

Brown, G. y. Atkins, M. (1988). Effective teaching in Higher Education. Londres: Ed. Routledge.

Campbell, J. (1949). The hero with a thousand faces. Nueva York: Bollingen Fundation Inc.

Campillo Ranea, J. E. (2010). La importancia de la educación emocional en las aulas. Recuperado de http://www.juntadeandalucia.es/educacion/ webportal/abaco-portlet/content/ab2f1 d46cd27-47f8-b849-e928a701df05. 
Gráfica de Atención Completa (G.A.C.), una propuesta metodológica educativa mediante proyectos interdisciplinares para el aprendizaje y mejora de la capacidad de atención-concentración a través del audiovisual y el arte

Flecha, R. y Puigvert, L. (2002). La comunidad de aprendizaje: una apuesta por la igualdad educativa. Rexe: Revista de Estudios y Experiencias en Educación, 1(1), 11-20.

Fortea, M. A. (2009). Metodologías didácticas para la enseñanza/aprendizaje de competencias.

García-Ruiz, R., Ramírez-García, A, RodríguezRosell, Ma. M. (2014). Educación en alfabetización mediática para una nueva ciudadanía prosumidora. Comunicar [en línea], XXI (juliodiciembre).

Gavara de Cara, J. C., Pérez Tornero, J. M. (2012). La alfabetización mediática y la Ley General de Comunicación Audiovisual en España (E. UOC Ed. 2012 ed.). Barcelona: UNESCO Institute for Inforation Technologies.

Goleman, D. (1996). Inteligencia Emocional. Madrid: Kairós.

González García, F. M. (1992). Los mapas conceptuales de J.D. Novak como instrumentos para la investigación en didáctica de las ciencias experimentales. Enseñanza de las Ciencias: Revista de Investigación y Experiencias Didácticas, 10 (2), 148-158.

Guillén, J. C. (2017). Neuroeducación en el aula, de la teoría a la práctica: Createspace Independent Publishing Platform.

Gutiérrez, A., Tyner, K. (2012). Educación para los medios, alfabetización mediática y competencia digital. Comunicar [en línea], XIX (s.f).

Marina, J. A. (2012). Neurociencia y Educación. Recuperado de http://www.joseantoniomarina. net/articulo/neurociencia-y-educacion/.

Mcluhan, M. (1972). La Galaxia Gutenberg: Génesis del "Homo Typographicus". Madrid: Aguilar S.A. de Ediciones.

Muñoz, E. (2010). Estructuración de los contenidos. pp. 25-34.

Pérez Tornero, J. M. (2008). Multi-screen society: a challenge for media literacy. [La sociedad multipantallas: retos para la alfabetización me- diática]. Comunicar, 31, 15-25. doi:https://doi. org/10.3916/c31-2008-01-002

Pública, C. S. d. E. (2010). Guía de observación para la detección de necesidades educativas especiales, con o sin discapacidad, en niños de educación básica. Recuperado de http://www. conafe.gob.mx/educacioncomunitaria/programainclusioneducativa/guia-educacion-basica. pdf.

Realinfluencers. (2017). 8 metodologías que todo profesor del siglo XXI debería conocer. Recuperado de http://www.realinfluencers. es/2017/03/02/8-metodologias-profesor-sigloxxi-deberia-conocer

Revista Educación 3.0. (2016). Método alternativo para la enseñanza de las matemáticas. Recuperado de http://www.educaciontrespuntocero. com/recursos/metodos-alternativos-para-la-ensenanza-de-las-matematicas/32992.html/

Robinson, K. (2010). La revolución del aprendizaje [ponencia presentada en la Conferencia Oficial de TED. Longbeach, California.

Sánchez-Escalonilla, A. (2009). Fantasía de aventuras. Claves creativas en novela y cine. Barcelona: Ariel.

Sandoval, Y. y Aguaded, J. I. (2012). Nuevas audiencias, nuevas responsabilidades. La competencia mediática en la era de la convergencia digital. Icono 14, 10 (3), 8-22. doi:10.7195/ri14.v10i3.197

Sousa, D. A. (2014). Neurociencia educativa: Mente, cerebro y educación. Madrid: Narcea Ediciones S.A.

Stewart, J., Van Kirk, J. y Rowell, R. (1979). Concept Maps: a tool for use in biology teaching. The American Biology Teacher, 41 (3), 171-175.

Strauss, A. L. y. Corbin, J. (1990). Basics of qualitative research: grounded theory, procedures and techniques. Newbury Park, CA.: Sage publications. 
Thompson, K. (1999). Storytelling in the New HoIlywood. Understanding Classical Narrative Technique. Cambridge: Harvard University Press.

Tokuhama-Espinosa, T. (2011). Mind, Brain, and Education Science: A Comprehensive Guide to the new brain-based teaching. United States Of America: W. W. Norton \& Company.

Tokuhama-Espinosa, T. (2017). El cerebro y el aprendizaje - Formación docente en el siglo XXI. Recuperado de: http://traceytokuhama.com/index.php?option=com_tz_ portfolio\&view $=$ article\&id $=437$ :el-cerebro-yel-aprendizaje-formacio-n-docente-en-el-sigloxxi\&catid=23\&ltemid=335.

Vizcaíno, P. (2016). Del storytelling al storytelling publicitario: el papel de las marcas como contadoras de historias. Universidad Carlos III de Madrid.

Vogler, C. (2002). El viaje del escritor. Barcelona, España: RobinBook, S.L. 


\section{La pronunciación en inglés para estudiantes de primer año de primaria: una secuencia didáctica para su mejoramiento}

Por: Mg. Karin Sepúlveda Navarro', Universidad de Concepción, Chile; Mg. Cecilia Quiroga C. ${ }^{2}$, Universidad de Concepción, Chile y Dr. Claudio Díaz L. ${ }^{3}$, Universidad de Concepción, Chile

Recibido: 2 de noviembre, 2017. Aceptado: 11 de marzo, 2018.

\begin{abstract}
Resumen
El presente artículo presenta un estudio realizado con 25 estudiantes de primer año de educación primaria, a los cuales se les se implementó una secuencia didáctica con actividades basadas en el enfoque de "Respuesta Física Total" para mejorar la inteligibilidad en la pronunciación del inglés. En esta secuencia didáctica los estudiantes observaron imágenes y escucharon vocabulario mediante videos y canciones, relacionándolos con movimientos corporales e interactuando a través de breves diálogos. La recolección de datos se obtuvo de un pre-test y post-test de pronunciación oral conformados por tres ítems: repetición de palabras, descripción de objetos y presentación oral, cuyos datos se procesaron mediante un análisis de frecuencia y porcentual. Asimismo, se llevó a cabo un análisis temático para las notas de campo y las entrevistas realizadas. Los resultados reflejaron un mejoramiento en la pronunciación a nivel de palabras, frases y oraciones en inglés, lo que permitió que los participantes produjeran mensajes inteligibles.
\end{abstract}

\section{Abstract \\ English pronunciation for first year primary school students: a didactic sequence implementation for its improvement}

This article presents a study conducted on 25 first-year primary school students. A didactic sequence was implemented utilizing activities that allowed participants to improve their intelligibility in the English pronunciation. The activities were primarily based on the Total Physical Response method for English teaching.

In this didactic sequence the students observed images and listened to vocabulary through videos and songs, relating them to body movements and interacting through brief dialogues. The data collection was carried out with a Pre and Post-Oral Pronunciation test, which included three items: Repetition of Words, Description of Objects, and Oral Presentation; the data obtained was processed by frequency and percentage. Likewise, a thematic analysis was conducted for field notes and interviews. The results revealed an improvement in the pronunciation at word, phrase, and sentence levels in English, and participants achieved an intelligible message.

1 Karin Sepúlveda es Magíster en Educación y labora como profesora de inglés en la Universidad de Concepción, Chile. Contacto: ksepulveda@udec.cl.

2 Cecilia Quiroga es Magíster en Educación y se desempeña como profesora de inglés en la Universidad de Concepción, Chile. Contacto: cquiroga@udec.cl.

3 Claudio Díaz es Magíster en Lingüística y Doctor en Educación, graduado de la Universidad de Concepción, Chile. Se desempeña como profesor de inglés y también como Director del Magíster en Innovación de la Enseñanza, Aprendizaje y Evaluación del Inglés, en esa misma casa de estudios superiores. Contacto: claudiodiaz@udec.cl.
Karin Sepúlveda N., Cecilia Quiroga C. y Claudio Díaz. La pronunciación en inglés para estudiantes de primer año de primaria: una secuencia didáctica para su mejoramiento. Revista Comunicación. Año 39, volumen 27, número 1, enero a junio, 2018. Instituto Tecnológico de Costa Rica. ISSN: 0379-3974 / e-ISSN1659-3820.

\section{PALABRAS CLAVE:}

Lengua extranjera, enseñanza, inteligibilidad, pronunciación, enfoque de Respuesta Física Total, secuencia didáctica.

\section{KEY WORDS:}

Foreign language, teaching, intelligibility, pronunciation, Total Physical Response method, didactic sequence. 


\section{INTRODUCCIÓN}

La enseñanza de una lengua extranjera involucra cuatro habilidades comunicativas: comprensión de lectura, comprensión auditiva, expresión escrita y expresión oral. Esta última involucra diversas variables que influyen en la comunicación e interacción entre hablantes. Una de ellas es la pronunciación, sistema por el cual se entrega un mensaje. Si el mensaje es comprendido, se podrá establecer el intercambio entre hablantes.

La motivación principal de esta intervención surgió a raíz de la observación directa de los discentes, quienes presentaban problemas de inteligibilidad en la pronunciación al expresarse oralmente en inglés. Esto se manifestaba de diferentes maneras en el actuar de los estudiantes como -por ejemplo- en la falta de participación activa en la sala de clases, la bajada de la mirada cuando el profesor les dirigía preguntas relacionadas con la materia, enrojecimiento y silencio. Debido a esto se dio la necesidad de plantear nuevas estrategias didácticas, desde los primeros años de escolaridad, que permitan un aprendizaje significativo y constante, y promuevan el interés y desarrollo lingüístico de los estudiantes, sin perder de vista que la enseñanza de un idioma extranjero requiere un proceso extenso para obtener los resultados deseados por parte de los educandos. El objetivo de esta investigación-acción consistió en implementar una secuencia didáctica sustentada en el enfoque de "Respuesta Física Total" para mejorar la inteligibilidad en la pronunciación en inglés en estudiantes de primer año de educación primaria. Tuvo una duración de cinco sesiones y cada una de ellas constó de dos horas semanales.

Este artículo se inserta en el contexto del proyecto Fondecyt 1150889, titulado Las dimensiones cognitivas, afectivas y sociales del proceso de planificación de aula y su relación con los desempeños pedagógicos en estudiantes de práctica profesional y profesores nóveles de pedagogía en inglés.

\section{MARCO TEÓRICO}

En el proceso didáctico existen diversos factores que influyen en el aprendizaje. En esta ocasión, se hará referencia a aquellos que se considera, deben estar presentes en la enseñanza de un idioma extranjero. Uno de ellos es el ambiente que se vive en una sala de clases. Según Casassus (2008), los ambientes tensos en las escuelas y el hogar atentan contra las capacidades de aprendizaje de los niños. Los ambientes sanos, por su parte, favorecen el equilibrio emocional y consecuentemente, el aprendizaje. Esto da a entender la gran importancia que tiene promover ambientes agradables para los estudiantes, en los cuales ellos se sientan seguros y propicien su desarrollo intelectual y emocional.

El aprendizaje de una lengua es lo que Krashen (2013) define como "un proceso consciente, ya que cuando estamos aprendiendo sabemos que estamos aprendiendo, esto es lo que sucede en la sala de clases" (p. 3). Al aprender una lengua extranjera (L2), los estudiantes comprenden diferentes aspectos relacionados con el vocabulario, la pronunciación y las estructuras gramaticales, los cuales son diferentes a los de la lengua materna. Al respecto, Ortega (2009) afirma que "en cuanto mayor sea la exposición a la lengua más rápido y completo será el aprendizaje" (p. 42). Asimismo, Yilorm (2016) asevera que "es sabido que mientras más sentidos estén incorporados en el proceso de enseñanzaaprendizaje, más se beneficia la apropiación de los saberes" (p. 112).

Vale señalar que las primeras etapas de adquisición de una lengua tienen lugar a través de procesos agradables con el apoyo de la interacción física, acompañados de la visión, habla, expresiones y gestos. Todo esto estimula las respuestas de los niños (Castro y Navarro, 2014). Por su parte, McLaughlin (2012) refiere que "los niños pequeños se acercan a la tarea de aprender la segunda lengua de una manera similar a la que aprenden la lengua materna" (p. 14). Por lo tanto, es necesario partir desde la vivencia de los alumnos mediante alguna experiencia práctica del aspecto que se abordará en los contenidos por tratar (Halbach, 2008).

En la enseñanza de lenguas extranjeras uno de los enfoques más conocidos a nivel mundial es la "Total Physical Response" (TPR), en adelante referida como enfoque de "Respuesta Física Total", creada en 1977 por James Asher, profesor de psicología en la Universidad de San José, California. Al respecto, 
Asher (2003) señala que este enfoque se "caracteriza principalmente por la coordinación del habla y la acción, por el que se intenta enseñar el lenguaje a través de la actividad física" (p. 73). El enfoque de "Respuesta Física Total" trabaja las acciones físicas acompañadas de órdenes, ya que enseña mediante mandatos imperativos y movimientos corporales.

Desarrollar actividades de "Respuesta Física Total" es quizás la herramienta lingüística más útil para un profesor que pretende que los estudiantes adquieran un segundo idioma, ya que las habilidades que se desarrollan se retienen por semanas, meses e incluso años (Asher, 2003). Por su parte, Mastromarco (2004) sostiene que la relación entre el lenguaje y la respuesta física permite la comprensión inmediata de las palabras, afirmando que "la Respuesta Física Total establece una relación entre la causa (el lenguaje) y el efecto (la respuesta física) que hace que el significado de las palabras sea comprendido inmediatamente" (p. 2).

Asher (2003) postula que "la respuesta física del niño señala que el mandato fue comprendido" (p. 56). Es importante considerar que se debe comenzar por mandatos simples como: Stand up, Sit down. Luego se avanza con mandatos más complejos, como: Sit down slowly. Estos "deben ser realizados entre 3 y 4 veces hasta que los estudiantes se sientan preparados para hacerlo por sí mismos" (Muñoz y Valencia, 2011, p. 21). En la enseñanza de una lengua extranjera en el contexto escolar, si la comprensión se ha desarrollado antes de hablar, el éxito en el aprendizaje está garantizado (Asher, 2003). Tal como indican Richards y Rodgers (2002), "los estudiantes hablarán cuando se sientan preparados para hacerlo, a esto se llega cuando han internalizado el lenguaje" (p. 76).

A menudo, cuando los estudiantes aprenden una L2 traen consigo experiencias previas que influyen en la disposición para su aprendizaje. Al respecto Casassus (2008) afirma que "la relación del alumno con la materia a aprender es emocional: le interesa o no le interesa, le gusta o no le gusta, lo afecta o no lo afecta, mientras menos lo afecta muestra menos interés" (p. 89). Por ese motivo es importante propiciar ambientes adecuados, en los cuales se otor- guen herramientas y se utilicen métodos adecuados para facilitar el aprendizaje.

El enfoque de "Respuesta Física Total" permite el desarrollo de una de las actividades preferidas de los niños que, además cobra gran relevancia, especialmente en educación primaria: el juego. Este ha sido utilizado para la diversión en tiempo de ocio, pero los expertos afirman que es un medio idóneo para adquirir conocimientos (Rubio y García, 2013). Para los niños el juego no es solo una herramienta indispensable en el desarrollo físico, cognitivo, psicológico y social, sino también es el mecanismo de aprendizaje más importante en esta etapa de la vida (Delgado, 2015). De acuerdo con Rubio y García (2013) "los juegos ofrecen a los participantes confianza en sí mismos y en sus capacidades" (p. 170).

La pronunciación en la enseñanza de un segundo idioma es el factor que permite a los estudiantes comunicarse de manera más eficaz y rápida con el otro. Por consiguiente, la pronunciación no es solamente portadora de contenido léxico-semántico de las unidades lingüísticas, sino que aporta valor comunicativo de enorme importancia al mensaje, ya que transmite actitudes, intenciones y expresiones (Blanco, 2012). En Chile, una pronunciación inteligible es uno de los aspectos más complicados de dominar en un ambiente escolar, debido a la escasa exposición que existe en el entorno de la gran mayoría de los educandos.

Expertos en la pronunciación, por años han destacado que el mejoramiento de la inteligibilidad es el principal objetivo en la enseñanza de una lengua extranjera (Munro y Derwing, 1995). Los investigadores Munro y Derwing (1995) han realizado diversos estudios relacionados con la inteligibilidad y la definen como "el grado en que se entiende el mensaje del hablante por el oyente" (p. 76). Si no existe una adecuada pronunciación cuando hablamos e interactuamos con los demás, será difícil para el oyente comprender el mensaje que se desea transmitir y de esta manera alcanzar la interacción entre hablantes. Es por ello que es importante exponer a los estudiantes al inglés utilizando los medios más apropiados, valiéndose de enfoques como la "Respuesta Física Total", ya que permite la comprensión y pronunciación del vocabulario relacionándolo 
con movimientos corporales. Asimismo, se refuerza y enfatiza la pronunciación a través de una práctica constante del idioma.

\section{MATERIALES Y MÉTODOS}

El presente proyecto se desarrolló mediante la utilización de la metodología de investigación-acción, puesto que es la que más se adecuaba al tipo de investigación que se deseaba llevar a cabo, incluyendo la participación directa del profesor. Para Kemmis (1988), citado en Latorre (2003), la investigación-acción "es una investigación sobre la práctica realizada por y para los prácticos, en este caso por el profesorado" (p. 25). Este autor refiere -además- que en el ámbito educativo la persona indicada es el mismo docente, ya que es él quien a diario está con los estudiantes y conoce la realidad del medio en el cual se desenvuelve (Latorre, 2003). En la educación es el profesor el que está en contacto directo y continuo con los discentes, conociendo y considerando así aquellas problemáticas que surgen en su realidad educativa y es él quien a su vez ha de innovar en su práctica. Según indica Elliott (2005), "la actividad educativa consiste en la elaboración y experimentación de un proyecto dirigido a facilitar el desarrollo de la comprensión en cada uno de los alumnos que componen el grupo de la

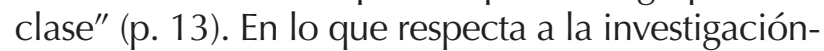
acción en educación, Latorre (2003) afirma que es un proceso que se caracteriza por su espiral cíclico entre la acción y la reflexión, de manera que ambos momentos quedan integrados y se complementan.

\section{OBJETIVOS DEL ESTUDIO}

- Implementar una secuencia didáctica sustentada en el enfoque de la "Respuesta Física Total" para mejorar la inteligibilidad en la pronunciación del inglés en estudiantes de primer año de educación primaria.

- Determinar el impacto de la secuencia didáctica en la pronunciación de los estudiantes a nivel de palabras, frases y oraciones en inglés.

- Identificar la percepción de los participantes sobre la intervención sustentada en el enfoque de "Respuesta Física Total".

\section{SUJETOS DEL ESTUDIO}

Los sujetos del estudio fueron 25 estudiantes, 12 niñas y 13 niños de 5 y 6 años de edad, de primer año de educación básica de un establecimiento de administración particular subvencionada, provenientes de la misma comuna. Todos los estudiantes procedían del mismo establecimiento educativo.

\section{DESCRIPCIÓN DE LA IMPLEMENTACIÓN}

La implementación de este proyecto en estudiantes de primer año de educación básica, cuyo propósito fue mejorar la inteligibilidad de la pronunciación en inglés, está fundamentada en el enfoque de "Respuesta Física Total", con el cual se pretendió que los estudiantes estuviesen expuestos al inglés a través de actividades lúdicas que les motivaran a participar activamente en su proceso de aprendizaje.

Las actividades fueron diseñadas de acuerdo con las necesidades observadas anteriormente, con el fin de desarrollar la pronunciación asociando las palabras a movimientos corporales. En la implementación de la secuencia didáctica sustentada en el enfoque de "Respuesta Física Total" se consideraron factores como el nivel e intereses de los estudiantes. El tema por desarrollar según la unidad didáctica correspondiente a primer año de educación básica fue My toys [Mis juguetes]. Es por ello que dentro del material concreto se consideró el uso de juguetes como apoyo para el desarrollo de la unidad. El presente proyecto se desarrolló en cinco etapas: pre-diagnóstico, diagnóstico, planificación, intervención, evaluación (véase la figura 1).

En la primera etapa de pre-diagnóstico se observó e identificó el problema al cual se deseaba dar solución. Luego, se procedió a adquirir la autorización formal del establecimiento para llevar a cabo el proyecto de investigación-acción. Una vez aceptada la petición, se procedió a solicitar la autorización de los apoderados para la participación de los estudiantes en dicha intervención. Posteriormente, se elaboraron los instrumentos de recogida de información: cuestionario sociodemográfico, test de pronunciación oral, entrevistas sobre la percepción del inglés y rúbricas de desempeño. 
La etapa de diagnóstico constó de dos secciones. En la primera se procedió con los estudiantes, quienes respondieron oralmente una serie de preguntas en español relacionadas con su realidad. Se aplicó -además- un test de pronunciación oral (pre-test de pronunciación), que consistió en tres ítems. En el primero, los estudiantes escucharon y repitieron una serie de palabras mencionadas por un hablante angloparlante. Las palabras repetidas fueron grabadas para su posterior análisis. En el segundo ítem, los estudiantes observaron útiles escolares, escogieron tres de ellos y los describieron, siendo nuevamente grabados. En el tercer ítem, los estudiantes expusieron oralmente una presentación relativa a la unidad de la familia. El fin de esta sección fue obtener información relacionada con el nivel de palabras, frases y oraciones que el educando podía mencionar en inglés.

En la etapa de planificación, de acuerdo con los resultados obtenidos en la etapa de diagnóstico, se programó una cantidad de sesiones, distribuyendo las actividades de la manera más adecuada posible para alcanzar los objetivos establecidos en la investigación, así como los materiales y recursos necesarios con el propósito de satisfacer las necesidades de los pequeños educandos. Luego de esto se procedió a la elaboración de las actividades basadas en el enfoque de "Respuesta Física Total", las cuales serían utilizadas en la etapa de intervención, ya que ellas promueven una participación activa por parte de los estudiantes al realizar movimientos corporales relacionados directamente con el vocabulario de la unidad trabajada, lo que promueve la retención y reconocimiento de este. Además, se consideró el uso de grabaciones de los estudiantes y notas de campo, ya que estas permitirían una observación directa de aquello que ocurría en el proceso mismo de la intervención.

Durante la etapa de intervención se llevaron a cabo cinco sesiones de 90 minutos. Cada una estaba constituida por una estructura similar en la que se comenzaba con el saludo mediante un canto de bienvenida, con lo que se daba inicio a la clase. Después se recordaba el vocabulario de la sesión previa, para lo que se utilizaba realia [objetos reales]. Posteriormente, se observaba un video relacionado con el entorno de los estudiantes y el vocabulario que se desarrollaría en la unidad. Seguidamente, se procedía al uso del enfoque de "Respuesta Física Total". Los estudiantes escuchaban y observaban movimientos corporales realizados por el profesor al mencionar uno de los juguetes de la unidad. Estos movimientos eran imitados por los discentes, luego repetidos oralmente.

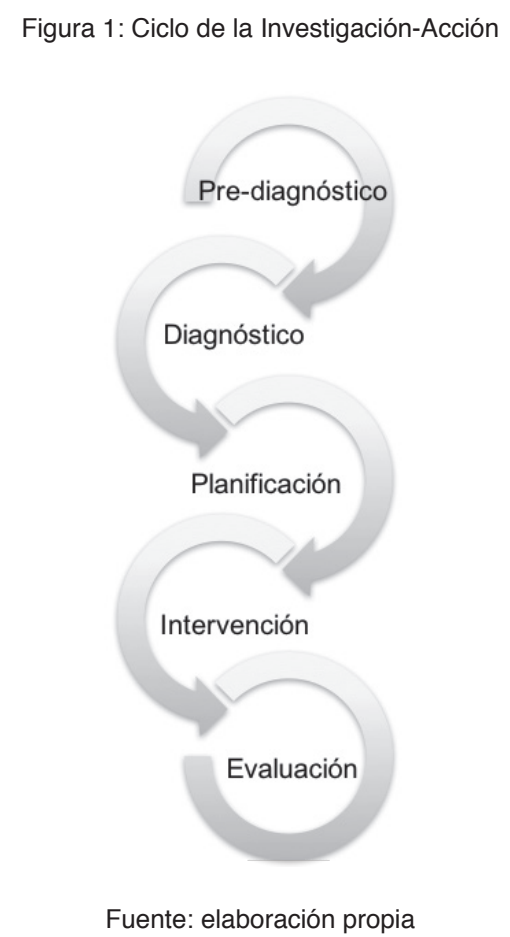

En una primera instancia, los estudiantes observaban para después dar la posibilidad, a uno o dos voluntarios, de pasar frente a la clase y pedir al resto de sus compañeros reaccionar físicamente a los mandatos que ellos proponían, así como mencionar los juguetes según lo que observaban por parte de sus compañeros. De esta manera, los discentes participaban en la clase, generando también un clima más agradable para disfrutar y aprender en conjunto con sus pares. Asimismo, se utilizaban canciones, interacción entre pares, especialmente en la realización de las actividades que incluyeran la producción de breves diálogos. Al término de cada sesión los estudiantes resumían lo que habían desarrollado y mencionaban lo aprendido. Finalmente, se procedía a la despedida. De esta forma existía una claridad en lo que correspondía al término de la clase. Al finalizar la intervención, se aplicó el post-test de pronunciación que contenía la misma estructura del pre-test 
de pronunciación, modificando solamente el contenido; esto con el objetivo de comparar los resultados obtenidos en ambas etapas de la investigación.

Una vez recolectada la información, se reflexionó y analizó en torno a los resultados conseguidos, ya que de acuerdo con ellos se pueden diseñar actividades para adaptar y mejorar las acciones llevadas a cabo, con el fin de que los estudiantes alcancen mejores aprendizajes en cuanto a la enseñanza del inglés.

\section{INSTRUMENTOS DE RECOGIDA DE LA INFORMACIÓN}

\section{Test de pronunciación oral (pre y post-test de pro-} nunciación) (véase el Anexo 1)

Con el propósito de obtener la información necesaria sobre el nivel de inteligibilidad de los estudiantes en inglés, se aplicó un pre-test de pronunciación en inglés grabado individualmente en formato mp3. El test fue organizado en tres ítems, en los cuales se evaluaba a los estudiantes a nivel de palabra, frase y oración en inglés.

\section{Rúbrica analítica de desempeño de repetición de palabras (véase el Anexo 2)}

La rúbrica analítica de desempeño de repetición de palabras constaba de un criterio que abordaba la repetición de palabras y tres niveles de desempeño: Adecuado, Suficiente e Insuficiente, lo que sumaba un total de 15 puntos. La pronunciación de palabras fue transcrita individualmente y contaba con el modelo de pronunciación ideal y la pronunciación del estudiante. Cabe señalar que esta rúbrica fue utilizada al inicio del proyecto en la etapa de diagnóstico y luego de la intervención. La única modificación surgió en la sección de transcripción de palabras, ya que eran diferentes a las evaluadas en el pre-test de pronunciación.

\section{Rúbrica analítica de desempeño de descripción de objetos}

La rúbrica analítica de desempeño de descripción de objetos constaba de un criterio que buscaba evaluar la inteligibilidad de las frases de los estudiantes al describir tres objetos y contaba con tres niveles de desempeño: Adecuado, Suficiente e Insuficiente. Las oraciones producidas por los estudiantes fueron posteriormente transcritas en el mismo documento. Se utilizó la misma rúbrica de desempeño para el pre-test y post-test de pronunciación.

\section{Rúbrica analítica de desempeño en la presentación oral}

La rúbrica analítica de desempeño en la presentación oral contenía igualmente un criterio cuyo objetivo principal era obtener el nivel de inteligibilidad de los estudiantes al producir oraciones mediante una presentación oral. Los niveles de desempeño considerados fueron cuatro: Excelente, Bueno, Suficiente e Insuficiente y al igual que las demás rúbricas, esta fue utilizada para analizar el pre-test y post-test de pronunciación.

\section{Notas de campo}

El instrumento de observación utilizado en la etapa de seguimiento fue el de notas de campo, las cuales consideraron la descripción detallada de las reacciones de los estudiantes durante las actividades desarrolladas en las cinco sesiones de la intervención. Estas reflejaron de la forma más fiel y objetiva posible lo acontecido en la sala de clases.

\section{PROCEDIMIENTO DE APLICACIÓN DE LOS INSTRUMENTOS}

Test de pronunciación oral (pre-test de pronunciación)

El pre-test de pronunciación fue aplicado antes de la intervención y constaba de tres ítems. En el primero, los estudiantes repetían palabras aisladas luego de escuchar la palabra grabada en un diccionario en formato digital. En el segundo ítem, los estudiantes escogían tres objetos que estaban en la mesa del profesor y los describían. En el tercer ítem los estudiantes realizaron una presentación oral. Los primeros dos ítems fueron grabados durante el primer bloque (8:30 a.m.), con una duración aproximada de 45 minutos, mientras que el tercero, una presentación oral, tuvo lugar en el segundo bloque (9:15 a.m.), con una duración de 30 minutos aproximadamente. 


\section{Notas de campo}

Las notas de campo fueron tomadas en un cuaderno al finalizar cada una de las sesiones correspondientes. En ellas se apuntaba el día, la hora, cantidad de participantes, así como la distribución de la sala de clases y lo más importante, la reacción de los estudiantes frente a las actividades que desarrollaron en la intervención.

\section{Test de pronunciación oral (post-test de pronuncia- ción oral)}

El post-test de pronunciación fue aplicado luego de la intervención, el cual contenía la misma estructura del pre-test de pronunciación. Este tuvo lugar en la sala de clases. En el primer bloque se aplicaron los dos primeros ítems, con una duración aproximada de 45 minutos. El tercer ítem tuvo una duración de alrededor de 30 minutos. En esta etapa fue posible evaluar a la mayoría de los estudiantes. Hubo solo tres que no asistieron a clases por problemas de salud. Ellos fueron evaluados en la siguiente clase.

\section{PROCEDIMIENTOS DE ANÁLISIS DE LA INFORMACIÓN}

La interpretación de la información obtenida se realizó mediante el análisis de frecuencia y porcentual. Se procedió primeramente a la transcripción de cada una de las rúbricas utilizadas: rúbrica analítica de desempeño de repetición de palabras, rúbrica analítica de desempeño de descripción de objetos, rúbrica analítica de desempeño en la presentación oral. Luego, de la transcripción de los datos, estos fueron traspasados a formato .XLSX (Excel) y se elaboraron gráficos para su posterior análisis. El proceso de seguimiento se llevó a cabo por medio de notas de campo en las que se llevó a cabo una observación descriptiva que permitió la realización de un análisis temático de las clases observadas.

\section{RESULTADOS}

Los resultados obtenidos en ambas evaluaciones, previo y posterior a la intervención, han demostrado que los estudiantes de primer año básico mejoraron notablemente su nivel de inteligibilidad, así como el vocabulario adquirido en la unidad desarrollada.
A continuación se presentan gráficos comparativos de las evaluaciones, en los cuales los primeros datos corresponden a los niveles alcanzados en la etapa de diagnóstico y los segundos a aquellos obtenidos después de la intervención.

En la figura 2 se observan los resultados obtenidos por los estudiantes en el primer ítem del test de repetición de palabras. En el pre-test de pronunciación, repetición de palabras, solo 16\% de los participantes alcanzó un nivel adecuado, mientras que en el post-test del mismo ítem casi la totalidad de los estudiantes alcanzó 96\% de logro. Esto muestra que la inteligibilidad de la pronunciación de los estudiantes se incrementó alrededor de 80\%.

Por otra parte, en lo que respecta al nivel Suficiente, en el pre-test de pronunciación fue alcanzado por $48 \%$ de los estudiantes y solo $4 \%$ en el mismo nivel del test aplicado posterior a la intervención (ver figura 2). Se debe destacar, además, que luego de la intervención ninguno de los estudiantes obtuvo un puntaje correspondiente al nivel Insuficiente. Los resultados reflejan un aumento considerable en el nivel de logro relacionado con la pronunciación de palabras aisladas.

Figura 2. Nivel de desempeño alcanzado en repetición de palabras

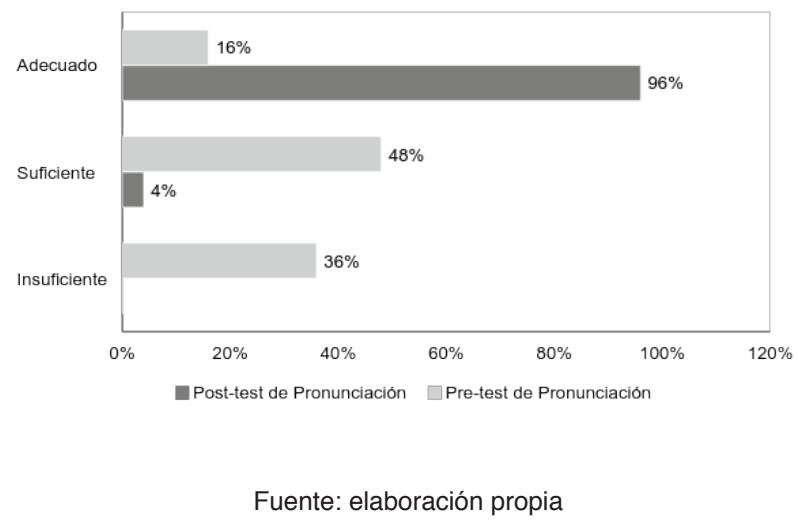

La figura 3, correspondiente a los resultados del segundo ítem, descripción de objetos, muestra un aumento en el nivel de desempeño Adecuado y Suficiente. En el pre-test de pronunciación 44\% se ubicó en el nivel Adecuado, mientras que en el post-test de pronunciación $60 \%$ en la misma sección. El desempeño de los estudiantes en esta sección aumentó en $16 \%$. En lo que refiere a un desempeño Suficien- 
te, disminuyó el porcentaje en 12\%. Los estudiantes mejoraron su nivel de desempeño y al igual que en el ítem anterior, ninguno obtuvo un nivel que lo ubicara en el nivel Insuficiente. Estos resultados arrojan nuevamente un avance positivo en cuanto a la descripción de objetos (véase la figura 3).

Figura 3. Nivel de desempeño alcanzado en descripción de objetos

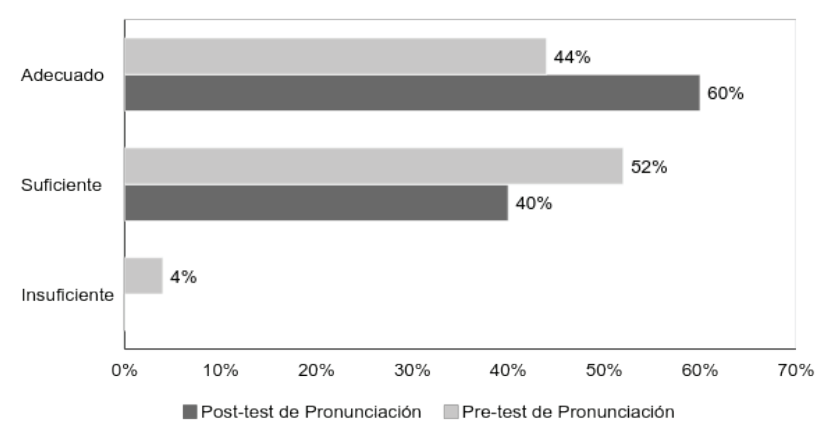

Fuente: elaboración propia

En la figura 4 se puede observar que en el último ítem del test de pronunciación, correspondiente a la presentación oral, el nivel de desempeño alcanzado por la mayoría de los estudiantes tuvo un incremento destacable en el mensaje transmitido. La casi inexistencia de errores conlleva a que lo expresado oralmente fuese completamente inteligible (véase la figura 4). Los porcentajes en el inicio de la investigación en el mayor nivel de rendimiento fueron alcanzados solo por $16 \%$ de los estudiantes, mientras que -después de la etapa de intervencióneste aumentó en $40 \%$. Vale destacar que -además de la inteligibilidad del mensaje- las oraciones emitidas fueron más completas y elaboradas, como lo refleja el participante 4: Hello, my name is Emilio. My robot is black, my ball is red, my hoop is green, my teddy is orange... En la primera presentación este participante no deseaba realizar la presentación oral, porque tenía vergüenza al no recordar las palabras ni su significado, por lo que manifestó: "No sé cómo, mamá. No recuerdo en inglés. Se me olvidó".

En lo concerniente a los niveles más bajos -Suficiente e Insuficiente- disminuyeron notoriamente. En el primero existe una disminución de 12\% con relación a la primera etapa y en el segundo ningu- no de los participantes se posicionó en el nivel más bajo de desempeño. Los porcentajes relacionados con el rendimiento de los educandos en cada uno de los ítems demuestran que hubo un aumento considerable en lo que respecta la inteligibilidad de los mensajes emitidos luego de haber sido intervenidos mediante la implementación del enfoque de "Respuesta Física Total".

Figura 4. Nivel de desempeño alcanzado en presentación oral

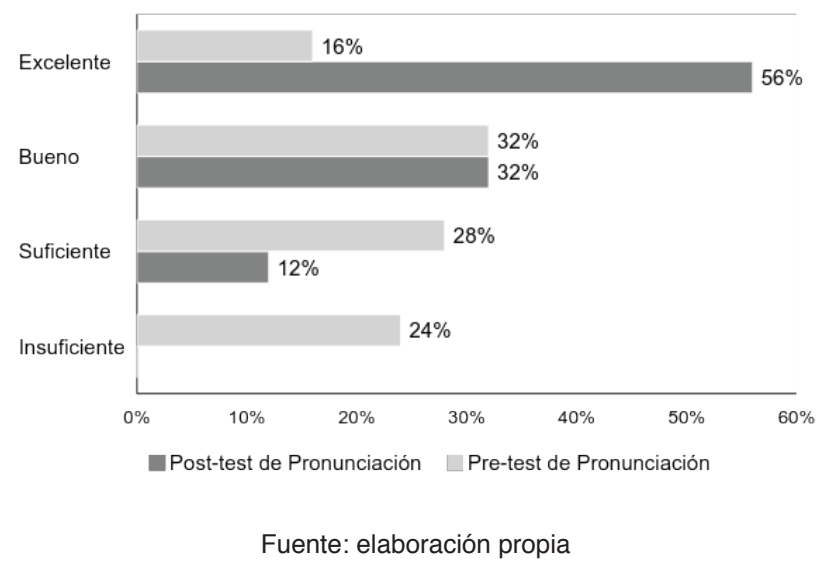

Al inicio y término de la investigación se llevó a cabo una entrevista de percepción sobre la asignatura de inglés. Al comparar los resultados de ambas entrevistas que -a pesar de no contener las mismas preguntas- apuntaban a un mismo objetivo, que era conocer el punto de vista de los estudiantes con respecto al inglés en el contexto escolar, los resultados de estas entrevistas mostraron que luego de la intervención los estudiantes tenían una reacción completamente positiva hacia el inglés. En las respuestas de la segunda entrevista, la mayoría de los estudiantes manifestó que le agradó todo lo que hicieron en las últimas sesiones. Los dos estudiantes que respondieron de forma negativa hicieron referencia específicamente a los objetos seleccionados, ya que estos no les identificaban.

En la primera entrevista dos estudiantes manifestaron que no les gustaba hablar en inglés, porque era muy difícil (participante 17) o porque solo sabían hablar en español (participante 24). En la segunda entrevista, luego de la intervención, los mismos estudiantes dijeron: "todo me gustó", "nada no me gustó". En lo que respecta a las actividades que contestaron les agradaban, se puede señalar que los 
estudiantes disfrutan definitivamente de actividades en las cuales puedan moverse, interactuar o manipular objetos jugando. En la primera entrevista ellos evidenciaron el gusto por jugar con sus pares y en la pregunta número dos -que se refiere a lo que más les gustó de las últimas clases de inglés- se repitió en reiteradas ocasiones jugar con los juguetes.

Las respuestas obtenidas y posteriormente comparadas demuestran que la actitud y percepción con respecto a la asignatura tuvo una mejora destacable respecto de la primera impresión conseguida en la etapa previa a la intervención. Mediante la implementación de actividades sustentadas en el enfoque de "Respuesta Física Total", los estudiantes -especialmente aquellos que mostraban una actitud negativa frente al inglés- modificaron su percepción, expresando el gusto por aprender este idioma mediante las diversas actividades desarrolladas.

Para concluir con la comparación de los resultados recopilados al inicio y término de la intervención y al observar los análisis recientemente descritos, se puede confirmar fehacientemente que el uso del enfoque de "Respuesta Física Total" permitió que los estudiantes mejoraran su nivel de desempeño y adquisición del idioma inglés casi por completo. Sus resultados destacables hacen ver que cuando se utilizan los métodos adecuados al nivel de desarroIlo de los estudiantes -considerando sus intereseses posible que estos mejoren su rendimiento académico sin dejar de lado la reacción positiva hacia la lengua extranjera, que es -sin duda alguna- uno de los principales factores en el aprendizaje, ya que aprendieron desde su propia experiencia, relacionando la expresión oral con los movimientos, al igual que los objetos con su realidad.

En lo que respecta al seguimiento de la intervención, esta etapa se llevó a cabo mediante el instrumento de notas de campo, lo que permitió reflejar la reacción de los estudiantes frente a las actividades desarrolladas durante las cinco sesiones. De acuerdo con los datos obtenidos, se observaron los siguientes resultados, mostrados en la figura 5, que ilustra la reacción de los estudiantes respecto de las sesiones llevadas a cabo en este proyecto de investigación-acción.
En las primeras sesiones, especialmente en la primera, los participantes observaron con sonrisas y rostros sorprendidos los juguetes en la mesa del profesor; esto los llevó a preguntar: "Miss, ¿para qué son los juguetes?". Con esta interrogante se dio inicio a la unidad. Todos los discentes miraron y escucharon atentamente los comentarios del profesor y respetaron el turno para dar su opinión respecto de los juguetes, procurando a su vez imitar las palabras que escuchaban en inglés. Al terminar la clase, los estudiantes se mostraron muy entusiasmados, expresando su satisfacción mediante comentarios como: "Me gustó la clase" o "A mí me gusta jugar con el teddy".

Asimismo, los estudiantes se mostraron cómodos al desarrollar las actividades relacionadas con movimientos corporales, expresión oral y breves tareas asignadas en la clase. Imitaron los movimientos que observaron y escucharon con las canciones intentando seguir su melodía y las palabras. En la última actividad de la primera sesión colorearon sus juguetes favoritos y los recortaron, pegándolos luego en un trozo de cartulina. El tiempo que les tomó realizar esta tarea fue el planificado y la desarroIlaron dialogando y compartiendo sus materiales. A su vez, en la tercera sesión -al observar un video relacionado con los juguetes- uno de los estudiantes -cuando vio la pelota- se puso de pie e imitó el movimiento mencionando el objeto. Luego de esto los demás siguieron su ejemplo y llevaron a cabo los movimientos correspondientes (véase la figura 5).

La figura 6 muestra que casi la totalidad de los estudiantes tuvo una participación activa en la mayoría de las actividades, especialmente en la primera sesión, en la que los educandos manipularon los juguetes. Algunos jugaron con el auto, otros tomaron la pelota, la dejaron en el suelo y realizaron breves movimientos con los pies. En voz baja algunos indicaron al compañero "Toma la pelota, pero con el pie" [sonrieron]. Sin embargo, en el inicio de esta misma sesión, la actividad en la que imitaron los movimientos del profesor relacionándolo con un objeto, se pudo observar que dos estudiantes, los más tímidos, no ejecutaron ningún movimiento, solo observaron a sus compañeros y al profesor. No obstante, luego de mirar a sus pares con rostros 
sonrientes y moviéndose libremente, comenzaron a esbozar sonrisas y posteriormente imitaron los movimientos.

\begin{tabular}{l} 
Figura 5. Reacción de los estudiantes en \\
las actividades desarrolladas \\
\begin{tabular}{|l|c|l|}
\hline $\begin{array}{c}\text { Reacción } \\
\text { de los estu- } \\
\text { diantes }\end{array}$ & $\begin{array}{c}\text { Cantidad } \\
\text { de estu- } \\
\text { diantes }\end{array}$ & \multicolumn{1}{|c|}{ Comentarios } \\
\hline Positiva & 23 & $\begin{array}{l}\text { En todas las sesiones } \\
\text { los estudiantes mostra- } \\
\text { ron rostros sonrientes } \\
\text { y sorprendidos frente } \\
\text { a las actividades desa- } \\
\text { rrolladas. }\end{array}$ \\
\hline Negativa & 2 & $\begin{array}{l}\text { En la primera sesión } \\
\text { los estudiantes más } \\
\text { tímidos no participa- } \\
\text { ron desde el inicio de } \\
\text { la clase, manifestando } \\
\text { no saber lo que se de- } \\
\text { bía hacer. }\end{array}$ \\
\hline Total & 25 & \\
\hline
\end{tabular} \\
\hline
\end{tabular}

La escasa participación de estos estudiantes fue completamente diferente en la segunda sesión, ya que en el inicio de la clase fueron precisamente ellos quienes levantaron su mano pidiendo pasar al frente de la clase para realizar los movimientos relacionados con los juguetes. Los más aventajados y con mayor personalidad se pusieron de pie para mostrar lo que habían aprendido, pero se autorregularon y respetaron su turno para poder participar. Asimismo, en las últimas sesiones la totalidad de los estudiantes participaron activamente en el intercambio de breves diálogos en los que describieron sus juguetes favoritos, manifestando así sus preferencias y respetando además su turno para hablar (ver figura $\mathrm{N}^{\mathrm{o}}$ 6). No obstante, en la sesión en la que se procedió a la repetición de palabras hubo tres estudiantes que en un principio estuvieron en silencio, período que para algunos fue necesario. Una vez que comprendieron el vocabulario, comenzaron a participar activamente repitiendo las palabras. Esta actitud se prolongó durante las sesiones precedentes.
Figura 6. Participación de los estudiantes en las actividades

\begin{tabular}{|c|c|c|}
\hline Actividades & $\begin{array}{l}\text { Cantidad } \\
\text { de estudi- } \\
\text { antes }\end{array}$ & Comentarios \\
\hline $\begin{array}{l}\text { Movimien- } \\
\text { tos corpo- } \\
\text { rales }\end{array}$ & 23 & $\begin{array}{l}\text { Solo dos estudiantes, } \\
\text { los más tímidos, no } \\
\text { participaron activa- } \\
\text { mente en el inicio de } \\
\text { la intervención, en la } \\
\text { realización de mov- } \\
\text { imientos. }\end{array}$ \\
\hline $\begin{array}{l}\text { Repetición } \\
\text { de palabras }\end{array}$ & 22 & $\begin{array}{l}\text { En esta sección que - } \\
\text { al parecer era la más } \\
\text { compleja- solo tres } \\
\text { estudiantes se mantu- } \\
\text { vieron en silencio, sin } \\
\text { repetir las palabras. } \\
\text { Esta actitud cambió en } \\
\text { la segunda sesión. }\end{array}$ \\
\hline $\begin{array}{l}\text { Manipu- } \\
\text { lación de } \\
\text { objetos }\end{array}$ & 25 & $\begin{array}{l}\text { Todos los estudiantes } \\
\text { manipularon los obje- } \\
\text { tos. Algunos jugaron } \\
\text { con ellos. }\end{array}$ \\
\hline $\begin{array}{l}\text { Interacción } \\
\text { con los } \\
\text { pares }\end{array}$ & 25 & $\begin{array}{l}\text { La totalidad de los es- } \\
\text { tudiantes interactuó } \\
\text { con sus compañeros } \\
\text { en un breve diálogo } \\
\text { por medio del que } \\
\text { manifestaron sus in- } \\
\text { tereses. }\end{array}$ \\
\hline
\end{tabular}

Fuente: elaboración propia

En la figura 7 se observa que el ambiente de la sala de clases era agradable. Los estudiantes mostraron sentirse libres y contentos al realizar movimientos y manipular los objetos, compartiendo e interactuando con sus pares. En la mayoría de las sesiones (4 de 5), los estudiantes se mostraron alegres en las diversas actividades desarrolladas durante la intervención (ver figura 7).

Vale destacar que en la primera sesión se escucharon risas a carcajadas debido a un error que cometió el profesor al querer dominar la pelota, ya que -en lugar de dominarla- esta golpeó la puerta de la sala. Algunos estudiantes comenzaron a reírse de 
inmediato, mientras el resto observaba al profesor esbozando leves sonrisas. Seguido de este desacierto por parte del docente, un estudiante intentó dominar el hula-hula con la cintura, pero no lo logró. Optó por hacerlo girar en su brazo, exclamando: "¡También se puede con el brazo!" y sonrió. Lo descrito vislumbra que el humor fue parte integradora de la sala de clases, propiciando desde el principio un ambiente atractivo para los estudiantes.

Sin embargo, en la penúltima sesión esta situación cambió debido a la presencia del profesor tutor en la sala de clases, ya que -al notar su presenciahubo estudiantes que le observaban bajando su mirada, sin participar activamente de las actividades que se desarrollaron mientras este permaneció en el aula. Esta actitud dio a entender que se sentían incómodos con su presencia. En síntesis, el ambiente percibido en casi la totalidad de las sesiones fue agradable para los estudiantes. Esto se manifestó en la participación activa por parte de ellos. El humor, la confianza y la relación entre pares, como con el profesor, permitieron que existiera un ambiente propicio para un aprendizaje significativo.

Figura $N^{\circ} 7$. Ambiente percibido en la sala de clases

\begin{tabular}{|c|c|l|}
\hline Percepción & Sesiones & \multicolumn{1}{|c|}{ Comentarios } \\
\hline Agradable & 4 & $\begin{array}{l}\text { En la mayoría de las } \\
\text { sesiones los estudian- } \\
\text { tes parecieron sentirse } \\
\text { cómodos, participando } \\
\text { activamente en las ta- } \\
\text { reas encomendadas. }\end{array}$ \\
\hline Desagradable & 1 & $\begin{array}{l}\text { En la penúltima sesión } \\
\text { se observaron rostros } \\
\text { que reflejaron timidez } \\
\text { con la presencia del } \\
\text { profesor tutor. Bajaron } \\
\text { la mirada, no hablaron } \\
\text { ni participaron durante } \\
\text { su presencia en la sala } \\
\text { de clases. }\end{array}$ \\
\hline
\end{tabular}

Fuente: elaboración propia

\section{DISCUSIÓN Y CONCLUSIONES}

Una vez finalizada la intervención de esta investigación-acción en la asignatura de inglés, fue posible constatar -por medio de los resultados obtenidosque la implementación fue la adecuada, ya que los niveles de logro alcanzados por los estudiantes fueron los esperados.

El uso del enfoque de "Respuesta Física Total" permitió que los alumnos adquirieran un mayor nivel de inteligibilidad, entregando un mensaje comprensible para el interlocutor, lo que promovía el movimiento corporal, producción de palabras y mensajes en inglés, con lo que se obtuvo una recepción positiva por parte de los estudiantes, respetando la etapa de desarrollo, sus intereses y motivaciones.

En el proceso de intervención se pudo confirmar la participación activa de los estudiantes en cada una de las sesiones, cumpliendo con los tiempos planificados (Muñoz y Valencia, 2011). Cuando los estudiantes expresaron abiertamente que deseaban manipular los juguetes, se coincidió con lo que afirman Rubio y García (2013) en cuanto al uso de materiales auténticos, ya que aumentó el nivel de implicación de los niños, incluso de los estudiantes más tímidos.

Las reacciones positivas de este grupo de estudiantes pueden dar cuenta de lo que señala Mastromarco (2004) respecto a la "Respuesta Física Total", ya que se estableció una relación entre el lenguaje y la respuesta física, lo que hizo que el significado de las palabras fuera comprendido inmediatamente. La ejecución de movimientos corporales demandó por parte de los estudiantes la comprensión de lo que realizaron disfrutando, lo que hacían sin necesidad de comprender la totalidad del vocabulario.

Es importante mencionar que los estudiantes a esta edad son bastante activos. Fue por ello que se decidió, acudiendo a los hallazgos de diversos investigadores en el área, implementar una secuencia de actividades fundamentada en el enfoque de "Respuesta Física Total", ya que promovió la participación activa de los estudiantes. Según señala Harmer (2007). "al ser niños su comprensión no proviene sólo de la explicación, sino también de lo que ellos ven y escuchan, con 
lo que tocan o con quien interactúan" (p. 82). Una vez adquirido el movimiento relacionando la acción con lo que escuchaban, se pudo pasar al reforzamiento de la pronunciación de palabras en inglés. No se forzó a los estudiantes a producir las palabras, ya que -como bien señalan Richards y Rodgers (2002) - "los estudiantes hablarán cuando se sientan preparados para hacerlo, a esto se llega cuando han internalizado el lenguaje" (p. 76).

Los resultados analizados demostraron que las actividades elaboradas para abordar las necesidades que presentaban los estudiantes en la pronunciación del inglés fueron las adecuadas. En relación con el impacto de la secuencia didáctica en la pronunciación de los estudiantes, los resultados comprobaron el mejoramiento en todos los ítems evaluados. En el primer ítem del test, la inteligibilidad de los discentes en la pronunciación, al repetir palabras aisladas se incrementó en $80 \%$ el nivel Adecuado luego de la intervención. Por otra parte, el porcentaje de estudiantes en el nivel Suficiente disminuyó en $44 \%$ respecto del pre-test de pronunciación. Además, es necesario señalar que posterior a la intervención, ninguno de los estudiantes se mantuvo en el nivel de desempeño Insuficiente.

En lo que respecta al segundo ítem del post-test de pronunciación, se observó un incremento de 16\% en el nivel Adecuado. Los resultados en este ítem manifestaron nuevamente un avance positivo en cuanto a la descripción de objetos. En el tercer y último ítem, los estudiantes obtuvieron un desempeño Destacable en la presentación oral. Su mensaje fue inteligible, aumentando su rendimiento en $40 \%$ en el nivel más alto de desempeño y al igual que en los ítems anteriores, ninguno de los estudiantes se ubicó en el nivel más bajo de desempeño. Mediante la secuencia de actividades implementada en esta investigación se logró un impacto positivo en los estudiantes, ya que superaron notablemente los niveles de desempeño alcanzados en la etapa de diagnóstico, mejorando claramente su pronunciación, además de adquirir nuevo vocabulario. Una vez finalizada la intervención, en la entrevista sobre la percepción del inglés, que tuvo relación directa con la opinión de los estudiantes acerca de la implementación del enfoque de "Respuesta Física total", estos expresaron que poseían una percepción positiva respecto de la enseñanza de este idioma en el contexto educativo.

Lo expuesto anteriormente demuestra que los objetos reales y cercanos a su entorno motivaron la participación activa desde el principio de la intervención, con los juguetes en sus manos fue posible apreciar la relación que los niños tienen con estos objetos, reflejándose en sus rostros sonrientes y la interacción que surgía al intercambiarlos, jugar con ellos por un momento mediante actividades lúdicas propiciaba un ambiente agradable, ideal para lograr aprendizajes significativos. La implementación del enfoque de "Respuesta Física Total" indudablemente permitió que los estudiantes aprendieran y pronunciaran las palabras de una manera más inteligible, puesto que promovió su respuesta mediante movimientos corporales. Para concluir, este proyecto de investigación-acción implicó que los estudiantes tuvieran la oportunidad de conocer una nueva forma de aprender un idioma extranjero mediante el enfoque de "Respuesta Física Total", que implicaba la participación activa en su propio aprendizaje, en el que la enseñanza de un idioma puede ser activa e interactiva dejando de lado el cuaderno, práctica a la que están habituados.

Al identificar los problemas que se presentan en la sala de clases, estos se pueden resolver utilizando los medios adecuados de acuerdo a la etapa e intereses de los estudiantes, ya que si se desea un cambio en la educación que vaya en beneficio de los que están en este proceso de aprendizaje, es necesario modificar las prácticas docentes.

\section{REFERENCIAS BIBLIOGRÁFICAS}

Asher, J. (2003). Organizing Your Classroom for Successful Second Language Acquisition. Recuperado de http://citeseerx.ist.psu.edu/viewdoc/do wnload?doi=10.1.1.549.2429\&rep=rep 1 \&type $=$ pdf.

Blanco, A. (2012). Corpus oral para el estudio de la adquisición y aprendizaje del componente fónico del español como lengua extranjera. RLA, Revista de Lingüística Teórica y Aplicada, 50 (2), 13-37. Recuperado de 
La pronunciación en inglés para estudiantes de primer año de primaria: una secuencia didáctica para su mejoramiento

http://www.scielo.cl/scielo.php?script=sci_artte xt\&pid=S0718-48832012000200002.

Casassus, J. (2008). Aprendizajes y emociones clima en el aula. Paulo Freire, Revista de Pedagogía Crítica, 7 (6), 81-95. Recuperado de http:// www.uca.edu.ar/uca/common/grupo18/files/ Aprendizaje_emociones_y_clima_de_aula.pdf.

Castro, I. y Navarro, L. (2014). The Role of Songs in First-Graders. "Oral Communication Development in English. PROFILE Issues in Teachers" Professional Development, 16 (1), 11-28. Recuperado de http://www.scielo. org.co/scielo.php?script=sci_abstract\&pid $=$ S1657-07902014000100002.

Delgado, I. (2015). El juego infantil y su metodología. Recuperado de https://books.google. $\mathrm{cl} /$ books?hl=es\&lr=\&id=sjidLgWM9_8C\&o $\mathrm{i}=\mathrm{fnd} \& p g=\mathrm{PA} 2 \& \mathrm{dq}=\mathrm{importancia}+\mathrm{del}+\mathrm{jueg}$ $\mathrm{O}+$ en+la+interacci $\% \mathrm{C} 3 \% \mathrm{~B} 3 \mathrm{n}+$ infantil\&ots= xEHE7vLL64\&sig=dtH2FUYfS7n9qcyeavvti HF_q_4\#v=onepage \&q=interaccion $\% 20$ social $\% 20 y \% 20$ comunicacion $\& f=$ false.

Elliott, J. (2005). La investigación-acción en educación. Recuperado de https://books.google.cl/ books?hl=es\&|r=\&id=eG5xSYGsdvAC\&oi=fn $\mathrm{d} \& p g=$ PA9\&dq $=$ Elliott $+1988+$ Investigacion $+\mathrm{a}$ ccion \&ots $=q$ T91 dob2q6\&sig $=$ AhQelldNTMs JlkKGjT--hu1 uXxE\#v=onepage \&q=Elliott\%20 $1988 \% 20$ Investigacion\%20accion \&f=false.

Halbach, A. (2008). Una metodología para la enseñanza bilingüe en la etapa de Primaria. Revista de Educación, 346 (1), 455-466. Recuperado de http://www.ince.mec.es/revistaeducacion/ re346/re346_17.pdf.

Harmer, J. (2007). The Practice of English Language Teaching. Recuperado de https://www.academia.edu/25472823/The_Practice_of_English_ Language_Teaching_4th_Edition_-_Jeremy_ Harmer.

Krashen, S. (2013). Second Language Acquisition: Theory, applications, and some conjectures. Recuperado de http://www.sdkrashen.com/content/articles/krashen_sla.pdf.
Latorre, A. (2003). La investigación-acción. Conocer y cambiar la práctica educativa. Barcelona: Editorial GRAÓ, de IRIF, S.L.

Mastromarco, A. (2004). Learning Italian at School with TPR by Playing, Creating, and Doing. Recuperado de http://www.tprworld.com/mm5/ merchant.mvc?Screen=CTGY \&Category Code $=200$.

McLaughlin, B. (2012). Second-Language acquisition in Childhood. Recuperado de https:// books.google.cl/books? hl=es\&lr=\&id=YdD XAQAAQBAJ\&o $i=f n d \& p g=P R 1 \& d q=a g e+$ and+secong+language+acquisition \&ots $=D$ 8A14vAg97\&sig=jt9HfYOEfiVTJC32yQK WaauNxU\# $\mathrm{v}=$ onepage $\& \mathrm{q}=$ age $\% 20$ and $\% 20$ secong\%20language $\% 20$ acquisition $\& \mathrm{f}=$ false.

Munro, M. y Derwing, T. (1995). Intelligibility: buzzword or buzzworthy? Segunda conferencia anual de procedimientos de pronunciación en el aprendizaje y enseñanza de una lengua extranjera (2010) Estados Unidos. Language Learning. 45. 73-97. Recuperado de http://jlevis. public.iastate.edu/2010\%20Proceedings $\% 20$ 10-25-11\%20-\%20B.pdf.

Muñoz, M. y Valencia, M. (2011). Teaching English Vocabulary to Third Graders Through the Application of the Total Physical Response Method. Pereira: Universidad Tecnológica de Pereira. Recuperado de http://repositorio.utp.edu.co/dspace/bitstream/handle/11059/1940/4281M971. pdf? sequence $=1$ \&isAllowed $=y$.

Ortega, L. (2009). Understanding Second Language Acquisition. Recuperado de https://books. google.cl/books?hl=es\&lr=\&id=30bKAgAAQB AJ\&oi=fnd\&pg=PP1 \&dq=Ortega + second + lan guage+acquisition\&ots=CbOW_WhOSy\&sig= WZx1HBxCQvrgEAjBG6uYVGFubo\#v=onep age $\& q=$ Ortega $\% 20$ second $\% 20$ language $\% 20$ acquisition $\& \mathrm{f}=\mathrm{false}$.

Richards, J. y Rodgers, T. (2002). Approaches and Methods in Language Teaching. Recuperado de 
https://ia601204.us.archive.org/6/items/ApproachesAndMethodsInLanguageTeaching2ndEditionCambridgeLanguageTeachingLibrary_201610/_Approaches_and_Methods_ in_Language_Teaching__2nd_Edition__Cambridge_Language_Teaching_Library_.pdf.

Rubio, A. y García, I. (2013). El uso de juegos en la enseñanza del inglés en la educación primaria. Revista de Formación e Innovación Educativa Universitaria. 6 (3), 169-185. Recuperado de http://refiedu.webs.uvigo.es/Refiedu/Vol6_3/ REFIEDU_6_3_3.pdf.

Yilorm, Y. (2016). Proceso de enseñanza aprendizaje de la lengua inglesa en escuelas públicas chilenas: ¿Producción o reproducción? Estudios pedagógicos 2016, 42, 103-116. Recuperado de http://www.scielo.cl/scielo.php?script=sci_ arttext\&pid=S0718-0705201600030000.

\section{ANEXOS}

\begin{tabular}{|c|c|c|}
\hline 告 & $\begin{array}{l}\text { UNIVERSIDAD DE CONCEPCION } \\
\text { FACULTAD DE EDUCACION } \\
\text { MAGISTER EN EDUCACION } \\
\text { Profesora: Karin Sepúlveda Navarro }\end{array}$ & 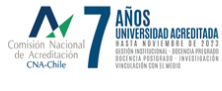 \\
\hline
\end{tabular}

\section{ANEXO 1:}

Test de Pronunciación Oral (Pre-Test y Post-Test de Pronunciación) (Extracto)

\section{Listen and repeat the following words:}

- Eraser

- Sharpener

II. Choose and describe three objects

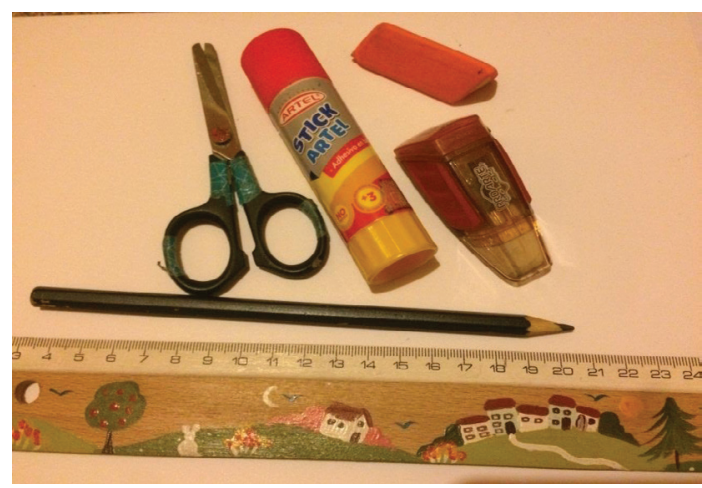

\begin{tabular}{|c|c|c|}
\hline 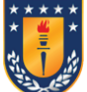 & $\begin{array}{l}\text { UNIVERSIDAD DE CONCEPCION } \\
\text { FACULTAD DE EDUCACION } \\
\text { MAGISTER EN EDUCACION } \\
\text { Profesora: Karin Sepúlveda Navarro }\end{array}$ & 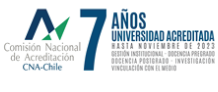 \\
\hline
\end{tabular}

ANEXO 2:

Rúbrica analítica de desempeño de repetición de palabras (extracto)

\begin{tabular}{|c|c|c|c|}
\hline Criterio & $\begin{array}{c}\text { Adecuado } \\
\mathbf{3}\end{array}$ & $\begin{array}{c}\text { Suficiente } \\
\mathbf{2}\end{array}$ & $\begin{array}{c}\text { Insuficiente } \\
\mathbf{1}\end{array}$ \\
\hline $\begin{array}{c}\text { Repeti- } \\
\text { ción de } \\
\text { palabras }\end{array}$ & $\begin{array}{c}\text { Correcta } \\
\text { pronun- } \\
\text { ciación }\end{array}$ & $\begin{array}{c}\text { Uno o dos } \\
\text { errores en } \\
\text { la pronun- } \\
\text { ciación }\end{array}$ & $\begin{array}{c}\text { Tres o más } \\
\text { errores en la } \\
\text { pronuncia- } \\
\text { ción }\end{array}$ \\
\hline
\end{tabular}

\begin{tabular}{|c|c|c|c|c|}
\hline $\begin{array}{c}\text { Palabra } \\
\text { grabada }\end{array}$ & $\begin{array}{c}\text { Pronunciación } \\
\text { del estudiante }\end{array}$ & $\mathbf{3}$ & $\mathbf{2}$ & $\mathbf{1}$ \\
\hline /'’rəIsər/ & & & & \\
\hline /'sa:pnər/ & & & & \\
\hline
\end{tabular}




\section{La enseñanza del arte en la escena global. El proyecto colaborativo entre el Centro de Investigaciones Artísticas (CIA) y la Maestría en Estéticas Contemporáneas Latinoamericanas (MECL/UNDAV)}

\author{
Por: Dra. Gabriela A. Piñero', Universidad Nacional del Centro de la \\ Provincia de Buenos Aires, Argentina y Universidad de Buenos Aires, \\ Argentina \\ Recibido: 2 de noviembre, 2017. \\ Aceptado: 15 de marzo, 2018.
}

\section{Resumen}

Este ensayo analiza la emergencia del Centro de Investigaciones Artísticas (CIA) en la ciudad de Buenos Aires en el año 2009, y su posterior colaboración con la Universidad Nacional de Avellaneda (UNDAV) a través de la Maestría en Estéticas Contemporáneas Latinoamericanas (MECL). La fundación de CIA participa de la emergencia en los años 90 y 2000 de una variedad de programas educativos de diverso grado de formalidad que difundieron en Argentina formatos de enseñanza del arte ya legitimados a escala global, pero inéditos a nivel local (las clínicas de arte y las residencias). Estos nuevos modelos educativos desplazaron las modalidades tradicionales de enseñanza del arte y buscaron instalar debates sobre las formas de producción, circulación y profesionalización propias de una escena artística globalizada. Firmado en el año 2016, el proyecto colaborativo CIA/UNDAV puede ser analizado a partir de las exigencias, en cuanto formación y profesionalización, que la escena global del arte impone al artista contemporáneo.

\section{Abstract}

Art Education in the Global Scene. The Collaborative Project between the Center for Artistic Research (CIA) and the Master Program in Contemporary Latin American Aesthetics (MECL/UNDAV)

This article analyzes the emergence of the Centro de Investigaciones Artísticas (CIA) in Buenos Aires (Argentina) in 2009 and its later collaboration with the Universidad Nacional de Avellaneda (UNDAV) through the master's degree in Contemporary Latin American Aesthetics (MECL). The creation of CIA is part of the emerging educational programs with varying degrees of formality that occurred during the period 1999-2000. These programs introduced different educational models of art teaching already globally established, but unknown at the local level (crits and art residences) in Argentina. These new educational models also replaced traditional models of art teaching and challenged contemporary forms of art production, circulation and professionalization. The CIA/UNDAV collaborative project (2016) can be analyzed according to the requirements - in terms of education and professionalization - that the global art scene demands of the contemporary artist.

1 Doctora y Magíster en Historia del Arte, graduada de la Universidad Nacional Autónoma de México. Licenciada en Artes, graduada de la Universidad de Buenos Aires. Actualmente es docente e investigadora de la Universidad Nacional del Centro de la Provincia de Buenos Aires (UNICEN) y profesora de posgrado en la Universidad de Buenos Aires (UBA). Contacto: pinero.gabriela@gmail.com.
Gabriela A. Piñero. La enseñanza del arte en la escena global. El proyecto colaborativo entre el Centro de Investigaciones Artísticas (CIA) y la Maestría en Estéticas Contemporáneas Latinoamericanas (MECL/UNDAV). Revista Comunicación. Año 39, volumen 27, número 1, enero a junio, 2018. Instituto Tecnológico de Costa Rica. ISSN: 0379-3974 / e-ISSN1659-3820.
PALABRAS CLAVE:

Educación artística, enseñanza profesional, artes, investigación, creación artística, innovaciones pedagógicas

KEY WORDS:

Art education, vocational education, arts, research, artistic creation, pedagogic innovation 


\section{El arte es un proceso de investigación (...) es un proceso de evolución de una idea, es prácticamente un trabajo científico}

David Lamelas

\section{INTRODUCCIÓN}

Fundado en el año 2009 por Roberto Jacoby, Graciela Hasper y Judi Werthein, el Centro de Investigaciones Artísticas (CIA) apareció en la escena local como uno de los primeros programas de formación artística que introdujo ciertos desplazamientos en la enseñanza del arte, ya legitimados a nivel global, pero entonces inéditos en Argentina. Los diversos cuestionamientos que los tres artistas dirigieron a las instancias formales de educación artística de comienzos de los años 2000 -las Escuelas de Bellas Artes y el recientemente creado, Instituto Universitario Nacional de las Artes (IUNA), hoy Universidad Nacional de las Artes (UNA)- se dirigían principalmente a tratar el desfase entre las modalidades de enseñanza y producción fomentadas desde estos espacios, y los saberes y experiencias que la escena artística contemporánea y la entonces incipiente industria cultural parecían exigir.

Consolidado desde entonces como uno de los espacios más experimentales de producción/reflexión artística a nivel local, en el año 2016 ClA anunció su colaboración con la Maestría en Estéticas Contemporáneas Latinoamericanas (MECL) de la Universidad Nacional de Avellaneda (UNDAV), Argentina. Dirigida por Adrián Cangi y coordinada por Alejandra González, desde su apertura en el año 2014 la maestría se propuso como un programa destinado a la "gestación de pensamiento crítico, de reelaboración de lenguajes artísticos y de entramado con las fronteras de la ciencia, la técnica y la tecnología" (MECL, 2018). Investigar la articulación de "las prácticas de los lenguajes artísticos con una posibilidad de verbalización o de textualización" se presentó como la posibilidad de aunar producción artística y reflexión teórica, entendiendo el ámbito de la escritura también como un espacio de producción creativa en el campo del concepto (González, comunicación personal realizada en 2017). Inscripta en el número creciente de maestrías y doctorados que desde el año 2006 se abrieron en Argentina en las diversas áreas de lo artístico (historia y teoría del arte, estudios culturales y visuales, curaduría, crítica de arte, producción artística), la MECL buscó distinguirse como el primer programa de posgrado que se replanteó la formación artística, a partir de reconocer la dimensión procesual e investigativa de todo proyecto artístico y la importancia creciente que la teoría adquirió en la producción artística.

Las siguientes páginas analizan la emergencia de CIA a partir del interés expresado por sus fundadores en diseñar y generar nuevos espacios formativos adaptados a las singularidades de la producción contemporánea; inquietud enmarcada en un momento de redefinición de la labor y profesionalización artística a escala internacional y de progresiva inscripción de las producciones locales en la escena global. Abordada por autores como Groys (2014, 2016), la red contemporánea de programas educativos, espacios de exhibición y fuentes de financiación marca un desplazamiento en cuanto a la figura tradicional de artista que actualiza y las formas de trabajo creativo que demanda. En este sentido, la colaboración CIA/UNDAV permite ser analizada como la formalización de algunas de las dinámicas de producción y enseñanza artísticas ensayadas en CIA (vigentes hasta entonces en espacios educativos de menor grado de formalidad) y su pleno reconocimiento como configuradoras de las instancias de formación, producción y legitimización contemporánea.

Este ensayo ofrece los resultados parciales de la investigación posdoctoral de la autora titulada "La reformulación de lo contemporáneo artístico. Crítica, curaduría, historia y nuevas plataformas colaborativas en las artes visuales recientes de Argentina y México", financiada por el Consejo Nacional de Investigaciones Científicas y Técnicas (Conicet, Argentina) entre los años 2014 y 2017. En esta investigación se analizaron los diversos procesos e instancias mediante las cuales a fines de los años 90 e inicios del 2000 se reconfiguró el régimen artístico que dominó la comprensión del arte reciente en Argentina y México. 
La enseñanza del arte en la escena global. El proyecto colaborativo entre el Centro de Investigaciones Artísticas (CIA)

y la Maestría en Estéticas Contemporáneas Latinoamericanas (MECL/UNDAV)

\section{ANTECEDENTES DE CIA: DEBATES SOBRE FORMACIÓN ARTÍSTICA EN ARGENTINA EN TORNO A LOS AÑOS 2000}

Este apartado presenta muy sintéticamente los antecedentes centrales de CIA referidos por sus fundadores. Es necesario realizar una cartografía más exhaustiva de los espacios y programas que en estos años se abocaron a la enseñanza del arte y difusión de nuevos formatos de producción artística que incluya los debates que los orientaban, así como la revisión de las articulaciones y diálogos entre los distintos ámbitos (universitarios, terciarios, programas de menor grado de formalidad, etc.).

En el 2002, Graciela Hasper, Inés Katzenstein y Agustina Cavanagh organizaron una mesa titulada "La formación de los artistas", en la cual se debatió el estado de la formación artística en la Argentina de aquellos años. "La formación de los artistas" fue la segunda mesa realizada en el marco de los Encuentros en el Goethe, gestionados por Inés Katzenstein, Agustina Cavanagh y Graciela Hasper en el año 2002. Las presentaciones y debates generados en estos encuentros fueron posteriormente desgrabados y publicados en la revista ramona (Katzenstein, Hasper y Cavanagh, 2003, pp. 32-59).

Los participantes de la mesa fueron Diana Aisenberg, Guillermo Kuitca, Tulio de Sagastizabal y Luis Fernando Benedit, artistas involucrados en proyectos disímiles que en los años previos al encuentro habían tenido una activa labor en la introducción y legitimación de nuevos formatos en la enseñanza del arte. Iniciada por Guillermo Kuitca en 1991, la Beca Kuitca introdujo el sistema de clínica en Argentina (Pineau, 2012, p. 607). Basado, según Kuitca, en la confianza y diálogo sostenido entre artistas, la clínica de arte planteaba una dinámica pedagógica que -si bien aparecía novedosa en el medio localestaba ya consolidada en programas de formación en el extranjero. Al respecto, Sarah Thornton indaga este formato educativo, conocido como crit, en el Master of Fine Arts del California Institute of the Art (Los Ángeles, Estados Unidos), donde funciona desde los años 1970 (Thornton, 2009, pp. 43-73).

Desde fines de 1980, Diana Aisemberg trabajó con este mismo formato (Katzenstein, Hasper y Cavanagh, 2003, p. 40) y años más tarde coordinó las "Clínicas del Rojas" en el Centro Cultural Rojas de la Universidad de Buenos Aires. Aisemberg fue también quien en gran parte difundió este formato en el interior del país con el apoyo de la Fundación Antorchas. Sobre el formato de la clínica de obra Aisemberg sostiene: "la clínica se basa en un entrenamiento dirigido a presentar la obra y al reconocimiento de 'qué clase de artista soy y quiero ser' y 'de qué se nutre el artista para definir su idea del arte y de su ser artista' a través de preguntas, regalos y trabajos de cooperación" (Katzenstein, Hasper y Cavanagh, 2003, p. 40).

El Taller de Barracas (1994-1995, 1996-1997), del cual Benedit fue tutor junto a Pablo Suárez y Ricardo Longhini, promovió la experimentación con nuevos materiales y formatos de obra. Finalmente, el proyecto Trama -fundado por Leonel Luna, Pablo Zicarello, Marcelo Grossman y Claudia Fontes en 1999- funcionó como un programa internacional de intercambio artístico.

El debate generado en el encuentro, que partía del relato de esas experiencias, reconocía la reconfiguración de los modos de producción, circulación y legitimación en una escena artística que progresivamente se abría a lo global. La distancia con las instancias de educación artística de mayor grado de formalidad, tales como las Escuelas de Bellas Artes, apareció de manera reiterada en la mesa. Hasper señalaba cómo los aportes más relevantes hechos en el campo de la educación en artes visuales habían provenido de espacios no oficiales y lamentaba la ausencia en la mesa de docentes y gestores vinculados a las instancias formativas oficiales, especialmente el IUNA creado a fines de 1996, a la vez que llamaba a una "modernización de los programas".

Por su parte, Kuitca refería la inexistencia de una academia dinámica capaz de participar de manera activa en la formación de artistas, y Ana María Battistozzi denunciaba el sistema decimonónico de talleres que aún regía las Escuelas de Bellas Artes. La verticalidad implícita en la relación maestroalumno, la rígida disciplinariedad de los talleres de grabado, dibujo y pintura, y la falta de articulación entre hacer artístico y pensamiento crítico fueron algunos de los aspectos que -según los participantes- alejaba las instancias de formación artística formales de la producción artística contemporánea (Katzenstein, Hasper y Cavanagh, 2003, p. 45) (se 
analizó algunos de estos desplazamientos en Autor, 2016).

A partir de este diagnóstico sobre el destiempo entre las formas de lo artístico transmitidas en las Escuelas de Bellas Artes y el IUNA -por un ladoy las concepciones que lo artístico adquiría en la escena contemporánea -por otro-, en 2006, Diana Aisenberg, Melina Berkenwald, Marcelo Grossman, Graciela Hasper y Roberto Jacoby gestionaron y coordinaron la primera edición de Residencia Internacional de Artistas en Argentina (RIAA), antecedente directo del $\mathrm{CIA}$.

La presentación del Centro de Investigaciones Artísticas en su sitio web señala las discusiones sobre formación artística, espacios de enseñanza y modelos educativos sostenidas en la primera edición de RIAA, como el germen de un proyecto que demandó tres años en sustancializarse. Según relata Graciela Hasper (2017), la apertura del CIA respondía al deseo de darle permanencia y continuidad a lo que de manera efímera sucedía en las residencias de RIAA. Así, mientras las primeras cuatro ediciones de RIAA (2006-2009) tuvieron lugar en el Viejo Hotel de Ostende, la quinta y última edición (2009) se desarrolló en el recientemente fundado $\mathrm{CIA}$ en la ciudad de Buenos Aires. Cabe destacar que RIAA fue un proyecto autogestionado y financiado con el apoyo de instituciones privadas nacionales e internacionales. Su primera edición (en Ostende, 2006) reunió por 15 días a 24 artistas visuales de entre 25 y 60 años de 12 nacionalidades distintas.

En palabras de Berkenwald (2006), la residencia funcionaba como "un espacio de encuentro entre artistas, y entre uno o varios artistas y un nuevo sitio de trabajo incluyendo a quienes integran dicho medio artístico". Los diálogos e intercambios generados en ese nuevo espacio, a través de la presentación y discusión de proyectos individuales, de actividades conjuntas y la misma experiencia de la convivencia, eran concebidos como elementos que enriquecían la práctica artística. El hecho de desarrollarse durante un período en lugares específicos (y en ocasiones alejados) buscaba sustraer a los participantes de sus obligaciones y distracciones habituales, y fomentar la concentración y continuidad de sus proyectos artísticos. En una suerte de balance sobre el aspecto educativo de esta experiencia, Ber- kenwald remarcó el aprendizaje colectivo surgido de un intercambio entre pares, distinto a la "dinámica alumno-profesor, artista-maestro" (Berkenwald, 2006, p. 39).

La idea de plataforma estuvo presente en cuanto la residencia se reconoció como generadora de proyectos e intercambios que excedían los 15 días de su duración. La inexistencia de talleres desplazaba los espacios habituales de formación y producción artística para privilegiar obras que atravesaban los medios y prácticas tradicionales y se conformaban a la vista de todos. Pinturas, instalaciones, videos, fotografía, intervenciones en el paisaje, performances, textos, muchas bajo la modalidad del site specific (sitio específico), fueron algunas de las piezas exhibidas a la comunidad local al cierre de la residencia.

Si bien experiencias como RIAA se presentaron innovadoras en el medio local de mediados y fines de los años 2000, eran formatos con los cuales los artistas organizadores ya estaban familiarizados. La experiencia de Hasper -la cual refiere su experiencia en la producción de Proyecto Sala 2 en el Centro Cultural Borges (2003) como otro antecedente de RIAA (Hasper, 2017) - y Berkenwald en instituciones y programas artísticos en el exterior, la labor artística y de gestión de Marcelo Grosman a través de Trama, las clínicas coordinadas por Aisemberg, además de los numerosos proyectos desarrollados por Jacoby desde los años 60 en los que la producción, gestión, promoción artística se entrecruzaban y participan en la generación de producciones artísticas híbridas y complejas permitían pensar en una constelación de saberes y experiencias que convergían en la generación de una nueva infraestructura para la formación y producción artística. En un texto que analiza el giro educacional en el arte contemporáneo (educational turn), Lázár refiere aquellos momentos en que ciertas dinámicas de enseñanza experimentales fueron concebidas en términos de práctica artística, desde el trabajo de Joseph Beuys hasta la crítica institucional de los años 80 y 90 (Lázár, 2017). 
La enseñanza del arte en la escena global. El proyecto colaborativo entre el Centro de Investigaciones Artísticas (CIA)

y la Maestría en Estéticas Contemporáneas Latinoamericanas (MECL/UNDAV)

\section{EL CENTRO DE INVESTIGACIONES ARTÍSTICAS (CIA) EN TANTO PLATAFORMA DE PRODUCCIÓN, FORMACIÓN Y PROMOCIÓN ARTÍSTICA}

Ideado como un programa pedagógico gestionado por artistas, CIA empezó sus actividades en agosto de 2009, en un edificio ubicado en la calle Tucumán, 3754/58 de la Ciudad de Buenos Aires, Argentina. Además, tiene base legal en la Fundación Start, responsable de otros proyectos también gestionados por artistas y estrechamente vinculados con el Centro, tales como la revista ramona (2000-2010), la red artística contemporánea Bola de nieve y el proyecto Venus, entre otros (http://www.fundacionstart. org.ar/proyectos).

En su presentación, hecha en la revista ramona, $\mathrm{CIA}$ se definió como "un espacio físico y virtual de encuentro y debate entre artistas y pensadores de todo el mundo, en particular de América Latina" (Hasper et al, 2009, p. 9). Con este objetivo y también con el de "proveer instrumentos críticos para la formación y desarrollo de la actividad artística para indagar e intervenir en los cambiantes mapas culturales del momento actual", desde su apertura, CIA convocó un equipo plural de realizadores de cine, teatro, artes visuales y música, filósofos, arquitectos, diseñadores gráficos, escritores y poetas, psicoanalistas, curadores, historiadores y teóricos relevantes de la escena actual. La interdisciplinariedad y la voluntad de hacer del centro un lugar -real y virtual- de debate y difusión de la producción contemporánea signaron en este sentido los inicios de dicho espacio.

Al ser un proyecto autogestionado, la realización de las distintas actividades fue en parte posible gracias a los numerosos apoyos y subsidios que CIA recibió a lo largo de sus años de existencia: Mecenazgo Cultural-Buenos Aires Ciudad, Foundation for Arts Initiatives de Nueva York, laspis International Artists Studio Program en Suecia y programa SIC Subvenciones a la Internacionalización de la Cultura Española (AECID), entre otros. CIA cuenta también con un Club de Amigos y mientras algunas de sus actividades son gratuitas y abiertas al público en general, otras son aranceladas y con cupo limitado.

Junto a la serie de actividades abiertas a la comunidad, ClA diseñó un programa de residencias y un programa de formación de artistas de un año de du- ración -el programa de agentes culturales CIA- que apelaban a convocar e incidir en la comunidad artística local. Si, por un lado, el programa de residencias fomentó el diálogo con realizadores de otros países y buscó dar a conocer las singularidades de la escena local al público internacional, el programa de artistas actualizó las dinámicas y tradiciones que orientaban la formación de los artistas a nivel local. Aunque el número de invitados internacionales se redujo en los últimos años por cuestiones presupuestarias, la heterogeneidad de voces convocadas y su relevancia en los debates artísticos internaciones, manifiesta la voluntad de hacer de CIA un espacio participante de las agendas de producción y debate global. En agosto de 2009 CIA inició sus actividades con una conferencia de Tania Bruguera. Ese mismo año contó con presentaciones de los artistas y curadores Josep-María Martín, Paul Ramírez Jonas, Claire Bishop y Teddy Cruz.

De igual modo, mediante su programa pedagógico, CIA sistematizó algunos de los desplazamientos en cuanto a las formas de producir y enseñar arte ensayadas por las experiencias referidas anteriormente: la importancia creciente que la reflexión teórica adquirió en la formulación de los proyectos artísticos, la interdisciplinariedad, la preeminencia del proceso sobre la obra final, el diálogo horizontal entre pares, formatos de obra tales como la instalación y la performance, que demandan un espectador activo y participativo.

Con un plan de estudios muy flexible y sin objetivos pautados a priori, las diversas actividades realizadas en el marco del programa agentes CIA -del que cada año participan 20 becarios- fomentan una aproximación a lo artístico en tanto práctica de investigación (más que como ámbito productor de objetos mercantiles) abierta a la incertidumbre y experimentación que cruza a través de disciplinas y especialidades (Jacoby, comunicación personal, 2017). Así, las consultorías de proyectos advierten sobre la dimensión procesual e investigativa de las producciones contemporáneas, a la vez que refieren a la concepción ya referida de lo artístico que, según Jacoby (conversación personal, 2017), orienta la labor del Centro. Por su parte, los talleres estimulan la investigación y la experimentación más que la adquisición de destrezas técnicas. Los cursos 
y seminarios profundizan aspectos teóricos e históricos de diversas cuestiones que signaron el arte del pasado y resultan relevantes en la escena actual. Finalmente, las conferencias funcionan como actualizaciones muy concretas sobre debates de la agenda contemporánea.

Si bien las temáticas de talleres y seminarios -así como los docentes- varían año a año, es factible identificar un interés constante en la performance y otras modalidades artísticas vinculadas con la utilización del cuerpo, y en la investigación de los cruces entre arte y política. La denominación de "agentes culturales" a los becarios que se forman en este espacio refiere a la expansión de lo artístico, la disolución de las fronteras entre disciplinas y al vínculo con lo social que CIA promueve con sus diversas intervenciones. En este sentido, lo artístico se actualiza a través del concepto de agencia, como intervención, praxis, acción situada que busca interferir en el vasto campo de lo cultural. Esta concepción de lo artístico arraiga en la propia práctica de Roberto Jacoby, uno de los fundadores de CIA y actual director, reconocido artista de la escena conceptual desde los años 60 (en el año 2011 Hasper renunció a la presidencia de CIA y posteriormente lo hizo también Werthein).

La ruptura disciplinar y la interrelación de medios artísticos, el intercambio y diálogo sostenidos con artistas, teóricos y curadores de diversas latitudes, la investigación y reflexión teórica como parte intrínseca del hacer artístico, pilares de la concepción de práctica artística promovida en $\mathrm{CIA}$, se tradujo en una particular distribución y organización del espacio. Actualmente, CIA funciona en el quinto piso de un edificio ubicado en la calle Bartolomé Mitre 1970 de la Ciudad de Buenos Aires. A través de la recepción se accede a dos grandes salones, también conectados entre sí, con una mesa y sillas. Allí se desarrollan todas las actividades de CIA. Ninguna de las dos locaciones contó con los tradicionales talleres de escultura, grabado y pintura. Salones despojados y pintados de blanco, repletos de sillas constituyeron en ambos edificios los lugares centrales de reunión, convivencia y trabajo.

El edificio de Tucumán contaba también con habitaciones y dependencias donde se alojaban quienes participaban de las residencias artísticas. En el edificio actual, que cuenta con una mediateca abierta al público con más de 1.000 libros (en papel y digitales), los viernes y sábado se desarrollan los seminarios, talleres y laboratorios de la MECL, en los cuales la discusión colectiva sobre los diversos proyectos se constituye en el acto de enseñanza y producción (obra y teoría simultáneamente), desplazando así la enseñanza de la técnica. En estos espacios, se promueve una idea de artista versado en la investigación, el análisis y la reflexión artística, una idea de artista que -si bien reniega de la profesionalización en términos de tecnocratización- está muy al tanto de las discusiones que marcan la agenda global, las instancias legitimadoras de la escena actual y las dinámicas de acceso a financiaciones, becas y subsidios.

\section{FORMALIZACIÓN Y APERTURA: LA COLABORACIÓN CIAVUNDAV}

En abril de 2016, CIA y la UNDAV firmaron un convenio de colaboración por realizarse en el marco de la Maestría en Estéticas Contemporáneas Latinoamericanas. Mientras la maestría se comprometía a gestionar y financiar los seminarios y cursos de posgrado, CIA garantizaba espacio físico para el desarrollo de las diversas actividades, así como su difusión. Durante los años 2014 y 2015 la maestría había desarrollado sus actividades en la Casa del Bicentenario, un espacio con el cual -sin embargo- no mantenía un proyecto académico común (González, comunicación personal, 2017). Iniciados de manera informal con anterioridad, los diálogos e intercambios generados entre ambos espacios ofrecían un beneficio mutuo en cuanto articulaban la estructura, presupuesto y flexibilidad de una universidad joven, con los contactos y legitimidad que en el ámbito del arte actual tenía CIA. En su tesis de maestría sobre la escena artística reciente, Agustina Battezzati analizó la trayectoria de una serie de artistas que exhibieron en el Malba y Mamba entre los años 2010 y 2014, e identificó a CIA como uno de los espacios de formación más elegidos por ellos (Battezzati, 2017).

El reconocimiento que Alejandra González, coordinadora académica de la maestría, hacía de CIA como el lugar actual del arte experimental, junto con el Programa de Artistas de la Universidad Tor- 
La enseñanza del arte en la escena global. El proyecto colaborativo entre el Centro de Investigaciones Artísticas (CIA) y la Maestría en Estéticas Contemporáneas Latinoamericanas (MECL/UNDAV)

cuato Di Tella, dirigido por Katzenstein, partía del diagnóstico (compartido con quienes siete años antes habían fundado CIA) sobre el carácter tradicional (en relación con la enseñanza de los lenguajes artísticos y su funcionamiento) de espacios formales de educación artística, tales como la UNA.

Desmarcándose de la oferta de posgrados en arte existente a nivel nacional, la MECL buscó inaugurar problemáticas nuevas en cuanto a las relaciones arte/política, producción/reflexión y discutir ciertas pautas de configuración de la academia. Desde su propio nombre, la maestría advertía sobre esta nueva delimitación curricular: estética pasaba así a referir al "sistema de evidencias sensibles que revela la existencia de formas de visibilidad en una comunidad en la que se relacionan maneras de hacer con modos de ser".

El estudio del territorio así demarcado ya no correspondía con la indagación (bajo una aproximación histórica) de las disputas y variaciones que definieron diversos abordajes de la estética en la tradición, sino al modo singular que -en el presentecada experiencia artística propone un reparto de lo sensible, una distribución de espacios, tiempos y funciones, y los modos en que los unos y los otros tienen parte en ese reparto. El acontecimiento artístico es reconocido así en su carácter político en cuanto disputa y redistribución de las funciones, espacios y tiempos (Ranciére, 2010). En esta misma dirección, la idea de lo contemporáneo se actualiza como ruptura, acción intempestiva que -justamente por su inadecuación- permite una puesta en crisis, un cuestionamiento del presente (Agamben, 2010). Frente a la imposibilidad de referir, desde el título, configuraciones territoriales como Nuestra América de José Martí, lo latinoamericano recupera el carácter situado de las intervenciones y producciones artísticas. En la línea practicada por $\mathrm{CIA}$, la MECL propone de esta manera una comprensión del pensamiento y la producción estética como acto polítiCO, acción situada.

Concebida como un programa de posgrado dirigido principalmente a artistas, es posible pensar las dinámicas que propone la $\mathrm{MECL}$, dentro de lo que Henk Borgdorff (2006) denomina "investigación en arte". Según el autor, esta perspectiva asume la no "separación de sujeto y objeto, y no contempla ninguna distancia entre el investigador y la práctica artística", y se basa en el presupuesto de que "no existe ninguna separación fundamental entre teoría y práctica en las artes (...) Conceptos y teorías, experiencias y convicciones están entrelazados con las prácticas artísticas y, en parte por esta razón, el arte es siempre reflexivo" (Borgdorff, 2006, p. 10).

Los talleres de CIA funcionan como espacios de experimentación sin derivar, necesariamente, en la producción de obra. En una línea similar, los laboratorios de la MECL se conciben como espacios de investigación y creación, sin una distinción entre teoría y práctica. En la MECL, la tesis final se propone como "un ensayo de interpretación estético-político articulado a una obra en el campo de creación específico" (MECL, 2018).

La idea antes expresada de Bergdorff sobre la no separación entre teoría y práctica en las artes se manifiesta asimismo en el acto de escritura. La crítica dirigida a la escritura académica y el intento de recuperar la tradición ensayística latinoamericana, advierte sobre esta misma voluntad de proponer, desde la interrelación, el ejercicio de escritura y producción de obra como praxis situada. La expresión que Borgdorff recupera de Donald Schön para referir a esta modalidad de práctica artística, "reflexión en la acción", se vincula al modo en que Katzenstein caracteriza la investigación pedagógica conducida en los talleres del programa de Artistas del Di Tella, otro de los programas de formación artística, también fundado en 2009, que González señala como relevantes de la escena actual.

El carácter inaugural en cuanto a las formas de enseñanza y práctica artística actualizadas tanto en CIA como en la MECL se advierte en la desestimación que ambos programas hacen de las instancias y dinámicas de formación artística tradicional. Sobre la selección de los "agentes culturales $\mathrm{CIA}^{\mathrm{A}}$ ", en la que interviene un jurado conformado por artistas, teóricos y curadores nacionales e internacionales, Jacoby sostiene que se priorizan "aquellos participantes con cierta experiencia en sus áreas de trabajo, independientemente de la posesión de títulos formales" (Jacoby, comunicación personal, 2017). Esta desatención reconoce no solo la multiplicidad de formas que asume hoy la producción artística y la pluralidad de trayectorias de sus realizadores, sino 
que también advierte sobre el desfase antes referido entre las concepciones y destrezas fomentadas en las escuelas tradicionales de arte y las modalidades que asume la práctica artística hoy.

El hecho de no requerir títulos oficiales o una formación específica para aplicar al programa de becas hace de sus integrantes un grupo disímil: artistas autodidactas, curadores, actores y directores teatrales, egresados de las carreras de artes y letras, etc. De un modo similar, el ingreso a la MECL no requiere contar necesariamente con títulos oficiales (profesorado o licenciatura), ya que también contempla el ingreso a través de la presentación de portfolio de artista. Esta posibilidad de acceder a un posgrado en artes a través de portfolio que dé cuenta de la producción hasta entonces desarrollada, sin la necesidad de haber transitado los espacios educativos tradicionales, reconoce y a la vez valida la pérdida de prestigio de las instancias formativas oficiales, en cuanto reconoce que el paso por las escuelas de bellas artes ya no es una instancia definitoria para la producción contemporánea.

Como señala Boris Groys (2014), estos desplazamientos dan cuenta de la globalización creciente en las últimas décadas, de "la red de escuelas de arte y de programas educativos" que proponen una "educación estética globalizada y bastante uniforme (...) basada en el mismo canon de vanguardia" (p. 103). La afirmación de Groys (2014, p. 105) de que "la desprofesionalización del arte es en sí una operación altamente profesional" refiere a la transformación en cuanto saberes y habilidades transmitidos en las escuelas de arte. El dominio de la técnica (pintura, escultura, incluso fotografía o video) ya no es definitorio de lo artístico, en un momento en que el arte se comprende también como modo de conocimiento y expansión de los horizontes de vida. El trabajo creativo ya no se concibe, necesariamente, como un trabajo en solitario, sustraído a la mirada e intercambio colectivo o incluso a la conciencia del autor (Groys, 2016, p. 206).

Los procesos de reflexión y producción fomentados a través de los talleres y consultorías de proyectos en CIA y los laboratorios de la MECL hablan en cambio de procesos creativos muy conscientes y sistematizados. La obra resultante ya no será "considerada creativa precisamente porque parece emerger de la nada" (Groys, 2016, p. 206), sino justamente por el trabajo de análisis y reflexión involucrados, por su posibilidad de visibilizar espacios, tradiciones y cuestiones silenciados, y poner en tensión el propio acto de intervención.

\section{CONCLUSIONES}

La escena artística argentina de fines de los años 90 e inicios de los años 2000 estuvo signada por una serie de intervenciones tendientes a reconfigurar el régimen artístico dominante, con el fin de alinear el arte local con los postulados que dominaban la escena global. Junto al despliegue de nuevas estrategias críticas y curatoriales destinadas a romper el mapa artístico dominante desde la segunda posguerra, que jerarquizaba las producciones de diversas partes del globo en centrales y periféricas, originales y derivativas, aparecieron en el medio una variedad de instituciones que funcionaron como agentes de globalización. La aparición de premios, becas y coleccionistas interesados en los nuevos formatos de producción se acompañó de la emergencia de una variedad de programas educativos de diverso grado de formalidad, destinados a difundir nuevas modalidades de enseñanza y producción. Ya legitimadas a escala global, las clínicas de arte, residencias y diversos espacios pedagógicos abocados al arte contemporáneo se fundaban en el diálogo e intercambio colectivo, en la preeminencia del proceso sobre la obra final y la importancia creciente que la reflexión teórica adquirió en la elaboración del proyecto artístico.

Con antecedentes en una serie programas y becas que emergieron en la Argentina en la década de 90, en el año 2009 se fundó el Centro de Investigaciones Artísticas (CIA) en la ciudad de Buenos Aires. Fundado por Graciela Hasper, Judi Werthein y Roberto Jacoby, su apertura respondió a la voluntad de generar un programa educativo capaz de atender las exigencias y singularidades propias de la producción contemporánea, y así propiciar un debate sobre el estado de la educación artística entonces vigente, caracterizada como tradicional y desactualizada por varios artistas y gestores de la época. Con énfasis en la investigación, la instancia procesual y la pesquisa teórica e histórica involucrada en el trabajo artístico, entre sus diversas actividades CIA 
La enseñanza del arte en la escena global. El proyecto colaborativo entre el Centro de Investigaciones Artísticas (CIA)

y la Maestría en Estéticas Contemporáneas Latinoamericanas (MECL/UNDAV)

fundó el Programa de Agentes Culturales CIA, un programa pedagógico de un año de duración que pronto adquirió gran legitimidad y reconocimiento en la escena del arte más reciente a nivel local y regional.

Abierta en el año 2014, la Maestría en Estéticas Contemporáneas Latinoamericanas se fundó en un mismo diagnóstico sobre la inadecuación entre las formas que lo artístico adquiría en la contemporaneidad y las metodologías y enseñanzas practicadas en las instancias más formales de educación artística (las Escuelas de Bellas Artes y la Universidad Nacional de las Artes). El proyecto colaborativo entre la MECL y CIA, firmado en el año 2016, puede -en este sentido- entenderse como una acción destinada a fusionar y potenciar la legitimidad de un programa de posgrado con reconocimiento oficial, con el prestigio de un programa pedagógico experimental gestionado por artistas. La progresiva formalización de algunos de los seminarios y cursos dictados en CIA -en términos de su adecuación a la estructura de seminarios de posgrado- se acompañó de la voluntad -por parte de la MECL- de revisar (abrir y diversificar) ciertos parámetros de definición de la academia. Estas reevaluaciones se apoyaron en una serie de reflexiones teóricas provenientes de la teoría del arte y la educación artística.

El giro político y las tendencias herederas del conceptualismo, dominantes en la escena global del arte desde los años 90 impulsaron estas revisiones en la enseñanza del arte en cuanto fomentaron producciones heterogéneas que -en ocasiones- involucraban importantes y ambiciosas investigaciones teóricas e históricas, y demandaban a los artistas saberes interdisciplinares y la colaboración con profesionales de diversas áreas. La nueva red de premios, becas y subsidios que aparecieron a escala local en esos años exigían, además, formatos de aplicación cercanos a los formatos académicos de presentación de proyectos prevalecientes en las ciencias sociales y humanas. Las reflexiones provenientes del campo de la educación artística y una pedagogía crítica -por otra parte- reconocieron los procesos de investigación y producción de conocimiento involucrados en muchas de estas prácticas y tuvieron que desarrollar formas de evaluación nuevas que desplazaban la noción de "calidad" como criterio de valoración de la producción artística.

Analizar cómo se forman y califican los artistas en la actualidad (García Canclini, 2014, p. 119) se revela así como una instancia necesaria para examinar la reconfiguración del régimen de lo artístico en la contemporaneidad. En este sentido, se abre una serie de preguntas que permitiría avanzar en esta comprensión: ¿cuáles son las diversas trayectorias del artista contemporáneo y cómo estas trayectorias han variado históricamente? ¿Cuáles son las reglas de valoración de las obras en la contemporaneidad y en qué medida las nuevas instancias y espacios de formación y profesionalización se adaptan a ellas y las modelan? ¿Cuáles son las nuevas formas, dinámicas y redes de trabajo artístico? ¿Cómo se conceptualizan los procesos artísticos y cómo se redefinió, en este momento histórico, el concepto de creatividad?

\section{REFERENCIAS BIBLIOGRÁFICAS}

Agamben, G. (2010). ¿Qué es lo contemporáneo?, Otra Parte. 20, 77-80.

Autor. (2016). Nuevas instancias de formación y la discusión sobre los modos de hacer arte en la contemporaneidad. Las clínicas de arte en Tandil, 2008-2009. IV Jornadas Internacionales y VII Jornadas Nacionales de Historia, Arte y Política. Facultad de Arte, Universidad Nacional del Centro de la Provincia de Buenos Aires.

Battezatti, A. (2017). La conformación de los valores artísticos contemporáneos. Participación y circulación en el Museo de Arte Moderno de Buenos Aires y en el Museo de Arte Latinoamericano de Buenos Aires. 2010-2014 (Tesis de maestría inédita) IDAES/UNSAM, Argentina.

Berkenwald, M. (2006). Cotidianeidad es en el presente contexto una palabra importante. Revista de artes visuales ramona. 63, 38-45. Disponible en www.ramona.org.ar.

Borgdorff, H. (2006). El debate sobre la investigación en las artes. Recuperado de https://www. gu.se/digitalAssets/1322/1322698_el-debatesobre-la-investigaci--n-en-las-artes.doc. 
Canela, J. (2017). La intensidad turbo. Entrevista a Inés Katzsenstein. Recuperado de http://terremoto.mx/article/la-intensidad-turbo/.

Elkins, J. (2017). Artists with PhDs. Recuperado de http://www.jameselkins.com/yy/.

García Canclini, N. (2014). El mundo entero como lugar extraño. Buenos Aires: Editorial Gedisa.

Groys, B. (2014). Volverse público. La transformación del arte en el ágora contemporánea. Buenos Aires: Caja Negra Editora.

Groys, B. (2016). Arte en flujo. Ensayos sobre la evanescencia del presente. Buenos Aires: Caja Negra Editora.

Hasper, G. (2007). Aires de cambio en Buenos Aires: clínicas, becas y proyectos. Revista de artes visuales ramona, 77, 51.

Hasper, G., Jacoby, R. y Werthein, J. (2009). El Centro de Investigaciones Artísticas. Revista de artes visuales ramona, 93, 9. Disponible en www.ramona.org.ar. Disponible en www.ramona.org. ar.

Katzenstein, I. (2017). ¿Hay arte en la escuela? Recuperado de http://www.coleccioncisneros.org/ es/editorial/debate/contribution/\%C2\%BFhayarte-en-la-escuela.

Katzenstein, I. e Iglesias, C. (Comps). (2017). ¿Es el arte un misterio o un ministerio? El arte contemporáneo frente a los desafíos del profesionalismo. Buenos Aires: Siglo XXI Editores..

Katzenstein, I., Hasper, G. y Cavanagh, A. (2003). La formación de los artistas. Revista de artes visuales ramona, 29-30, 32-58. Disponible en www.ramona.org.ar.

Lázár, E. (2017). Educational turn. Extraído de http:// worker01.e-flux.com/pdf/article_18.pdf.

Pineau, N. (2012). Espacios de exhibición durante los años noventa en Buenos Aires y la formación de una nueva escena artística. En M.I. Baldasarre y S. Dolinko (Eds.). Travesías de la imagen. Historias de las artes visuales en Argentina (607-635). Bs As: UNTREF.

Rancière, J. (2010). El desacuerdo. Estética y política. Bs As: Nueva Visión.
Rogoff, I. (2010). Turning. e-flux \#0. Recuperado de http://worker01.e-flux.com/pdf/article_18.pdf.

Romero, J.C. (2007). Escuelas de arte para la época. Revista de artes visuales ramona 77, 23-27. Disponible en www.ramona.org.ar.

Sternfeld, N. (2010). Unglamorous Tasks: What Can Education Learn from its Political Traditions? e-flux \#14. Recuperado de http://www.e-flux. com/journal/14/61302/unglamorous-taskswhat-can-education-learn-from-its-politicaltraditions/.

Thornton, S. (2009). Siete días en el mundo del arte. Buenos Aires: Edhasa. 


\section{La piedra literaria en el zapato de Bob Dylan: un análisis a la crítica temprana a su Nobel en Costa Rica y a su valor poético-literario}

Por: David Boza Méndez, Universidad de Costa Rica

Recibido: 23 de enero, 2018.

Aceptado: 15 de marzo, 2018.

\section{Resumen}

El año 2016 fue un año que representó un hito significativo histórico dentro de la cultura popular y el mundo de la música rock. Bob Dylan se convirtió en el primer músico en recibir el premio Nobel de Literatura. Dicho premio suscitaría una considerable crítica en los medios, tanto en revistas especializadas como en los diarios planetarios. En Costa Rica también se generó una interesante discusión periodística en relación con dicho galardón.

El presente trabajo expone un análisis de las similitudes y las diferencias en el discurso de esta crítica local al Nobel de Dylan. En este sentido, se presentarán los principales argumentos expuestos en los artículos y se partirá de algunos de estos enunciados para analizar la naturaleza de la música para ser cantada y así evidenciar la relación con la poesía y de esta manera poder generar un vínculo entre las dos artes. Para hacer más evidente dicho vínculo, se aborda el tema de la génesis común de estas. Un último apartado buscará exponer las características poéticas y literarias de las canciones de este cantautor.

Por último, este acercamiento tiene por motivo exponer las razones por las que el cantautor posee el perfil para ser acreedor de este galardón literario. Se partirá, en primera instancia, de la teoría expuesta por algunos críticos literarios y estudiosos de la cultura popular, además de utilizar el análisis semiótico como principal herramienta de análisis.

\section{Abstract \\ The literary pebble in Bob Dylan's shoe: an analysis of the early criticism in Costa Rica on his Nobel and his poetic-literary value}

2016 marked a momentous year in popular culture and rock music history when Bob Dylan became the first musician to win the Nobel Prize in Literature. This award generated a considerable amount of critique in the media, not only in specialized magazines but also in newspapers. Likewise, in Costa Rica, a number of newspaper articles dealt with the subject of Dylan's Nobel.

This study aims to analyze the similarities and differences in terms of the discourse of these articles. In this regard, this study presents a list of the main arguments on this subject; some of the statements serve as input for analyzing the nature of sung music and evince its relation with poetry. Furthermore, the notion of their common source is addressed in order to make this sonic-linguistic relation more evident. The last section intends to present the poetic and literary characteristics of Bob Dylan's songs. Finally, this study aims at demonstrating why the songwriter is a worthy recipient of a literary prize of this nature. These conjectures are based on the theories of some literary and popular culture experts; in addition, semiotic analysis represents the main tool for this study.

1 David Boza es graduado del Bachillerato en Inglés y la Maestría en Literatura Inglesa, en la Universidad de Costa Rica. Labora en esa misma casa de estudios superiores. Contacto: boza.braindamage@gmail.com

\section{PALABRAS CLAVE:}

Bob Dylan, premio Nobel, poesía, literatura, literatura contemporánea, canción, canto, estudios culturales

\section{KEY WORDS:}

Bob Dylan, Nobel Prize, poetry, literature, contemporary literature, song, singing, cultural studies 
La poesía revela este mundo.

Octavio Paz

\section{PALABRAS INICIALES}

\section{a) Introducción}

El año 2016 estuvo marcado por una serie de noticias relevantes en el acontecer de la cultura popular. Por una parte, los fallecimientos no solo de estrellas del cine y la televisión, sino también de grandes íconos de la música a nivel planetario, como David Bowie, Prince y Leonard Cohen. Por otra parte, se dio la sorpresa de ver cómo se le otorgaba el premio Nobel de Literatura a Bob Dylan, el mítico cantautor y creador estadounidense que impactaría por primera vez las radios norteamericanas a inicios de la década de 1960.

Pero no todo ha sido dicha y celebración de este merecido galardón al trabajo creativo y poético de este artista. Se generó una fuerte polémica con partidarios y se alzaron algunas voces de repudio y rechazo a dicha nominación. Grupos que condenaron la decisión de la academia sueca de otorgar el premio más significativo dentro de lo consabido como literatura a un músico y no a lo considerado convencionalmente como un escritor de oficio. En este sentido, los principales argumentos divergentes giraron en la relativa consideración de que la música no es literatura y mucho menos, la música popular, creada para ser consumida a través de grandes cadenas radiofónicas. Otros grupos inclusive reprobaron que el premio se le hubiera concedido a Dylan y no a uno de sus músicos predilectos, y sustentaron su postura afirmando que Dylan canta de una manera algo estrepitosa y tosca o que su música está pasada de moda y carece de complejidad.

Sin embargo, el hecho que la academia sueca haya tenido en cuenta la candidatura y su mirada en este cantautor resulta significativo en la valoración de su aporte cultural mediante el vehículo del canto. La academia sueca decidió otorgarle el galardón "por haber creado una nueva expresión poética dentro de la gran tradición americana de la canción". Lo anterior pone en evidencia que el jurado estaba valorando, junto con sus capacidades musicales, su impacto cultural, artístico y social, así como el estilo innovador de sus canciones.

El 13 de octubre del 2016 se alzaron muchas voces después de que la academia sueca hizo público su decreto. Se generó mucha discusión al respecto y Costa Rica no fue la excepción. Durante las semanas posteriores al anuncio oficial, varios críticos recurrieron al artículo periodístico para exteriorizar sus pensamientos en relación con la figura de Dylan y su designación al premio.

Lo importante de todas estas formas discursivas dicotómicas, a favor y en contra, es que se abrió un pertinente y polémico diálogo sobre las consideraciones en relación con lo consabido como el canon literario. Escritura, oralidad, música y estética son algunas de las categorías con que la crítica lanzó sus aseveraciones.

\section{b) Justificación}

Este acercamiento en primera instancia intenta sistematizar las ideas esenciales de algunas de estas publicaciones y busca crear conectores de ideas para así evidenciar las tendencias y posturas en relación con el premio Nobel de Literatura del 2016. Se hará referencia a la noción del cantautor y la canción como poesía para ser cantada. Con estas premisas teóricas, se intentará justificar la pertenencia de los textos de Dylan a estas categorías. Este acercamiento pretende evaluar la calidad poética de un tipo de texto, el cual no es considerado usualmente como tal, pero que -al analizarlo detenidamente- demuestra características propias de este arte.

\section{c) Premisas teóricas}

Este acercamiento se divide en apartados que intentan determinar la eventual dimensión literaria del cantautor:

i) La revisión y recuento de artículos periodísticos sobre este, y la consideración de las distintas posiciones de los articulistas.

ii) El análisis de los orígenes de la poesía y la canción, las similitudes que estas tienen y los caminos que a nivel histórico han recorrido. 
iii) El estudio de varios textos musicales del cantautor, que ponen en evidencia su condición poética.

El análisis se fundamenta en una de las principales premisas teóricas de los estudios culturales, mediante la cual se piensa que una producción puede ser considerada como un texto perteneciente al ámbito de la cultura y por consiguiente, puede ser analizado. Al mismo tiempo, esta aproximación utiliza el análisis literario sobre la base de los signos semióticos, de sociedad, cultura e historia como principales herramientas de la consideración entre texto y contexto.

Para abordar el tema de los orígenes de la poesía y la música y sus comunes denominadores se consultaron teorías de los estudiosos del folclor musical y poético, entre otros, los trabajos de Guillermo Barzuna (1996) y Juan Carlos Ureña (2013). Además, complementa el análisis literario el abordaje de textos sobre retórica literaria. De esta manera, se consultaron textos claves para abordar el género lírico, como los de autores Octavio Paz y Helena Beristein. Asimismo, se realizó la consulta de artículos en páginas web sobre las canciones de este cantautor y su valor poético y artístico.

\section{CRÍTICA TEMPRANA AL NOBEL}

En las semanas posteriores al controversial premio otorgado a Bob Dylan, aparecieron varios artículos en periódicos costarricenses en relación con dicho galardón. Diversos puntos de vista se expresaron con base en la decisión de la Academia Sueca, de apoyo, negación y cautela a la decisión. También se expresaron distintas posiciones con respecto a la conjunción entre la música y la poesía para intentar explicar el premio. Sin embargo, al comparar estos artículos de periódico, existen diversos puntos de vista compartidos relacionados con la escogencia del Nobel en Literatura, los vínculos entre poesía y música, así como la perspectiva del canon.

Una de las principales ideas expuestas y compartidas en varios de estos artículos corresponde al valor y la naturaleza de la poesía contemporánea. En los últimos cien años se ha dado un fenómeno de exclusión poética. La poesía ha excluido al lector común por medio de la adopción de estilos y temas más complejos. Esta se ha convertido en un metalenguaje con imágenes y sintaxis muy complejas. Esta poesía se centra en sí misma y en probar sus límites. Dichas exploraciones poéticas tienen como consecuencia el hecho de que el eventual lector que pueda leer e inclusive escribir poesía sea solamente una persona educada bajo esta reciente tradición poética.

Este cambio de rumbo ha tenido repercusiones no solo artísticas, sino también sociales. De acuerdo con la crítica, el poeta ya no es la voz de su pueblo, el extraño que todo lo ve, lo entiende y lo expresa por medio de un lenguaje pulido y refinado para hacerlo sonar estilizado. El poeta ahora es un ermitaño de biblioteca encerrado en muros de libros que lo imposibilitan para visualizar lo que pasa a su alrededor. Sus productos son mega-monstruos intertextuales e inter-teóricos que giran sobre sus propios ejes y han perdido esa cualidad de seducción de las masas. Los artículos de periódico citan nombres como Eliot y Pound (Cortés, 2016; Solórzano, 2016).

Ante la aparición de esta poesía excluyente, Bob Dylan y otros cantautores retoman la vieja tradición poética, la de hablarle al pueblo de temas reales y humanos. Este rescate de la figura del poeta y la vieja tradición poética viene de la mano de géneros artísticos no literarios, como la música popular. Dylan toma ritmos que le pertenecen al pueblo y con ellos crea una poesía cantada con el simple propósito de devolvérsela a este, que es donde esta pertenece. En este sentido, la imagen de Bob Dylan se apega más a la imagen tradicional del poeta (Cortés, 2016; Ramírez 2016).

Otra idea reincidente en los artículos periodísticos corresponde a la noción de que la poesía y la música son una, debido a que tienen un mismo origen (Ramírez, 2016; Solórzano, 2016). Estas dos ramas artísticas tienen su inicio en la antigüedad (Ureña 2013). En esa época existía un grupo de poetas cuyas obras literarias eran acompañadas de instrumentos musicales, actuación y una escenografía. A lo largo de su historia y hasta hoy la poesía todavía tiene características propias de la música, como su métrica (cantidad de golpes en un verso) y rima 
(sonidos reiterados que crean una sensación de armonía). Este origen común representa una de las razones principales para defender la naturaleza literaria de la lírica cantada presente en la música. Este argumento viene a refutar la creencia que diferencia de manera injusta y peyorativa la música cantada de la poesía y la literatura, una tesis recurrente que obvia las similitudes entre ambas, Ilámense verso, rima, métrica, reiteración, encabalgamiento y metáfora, las cuales -como ya se expuso- se remontan a la interdisciplinariedad artística en la antigüedad (Solórzano, 2016).

Pese a que la mayor cantidad de argumentos expuestos son positivos al sentido creador de Bob Dylan y buscan validar la designación del premio Nobel, varios de los artículos también presentan los principales argumentos en contra de la decisión de la Academia Sueca de otorgar dicho galardón a este cantautor. Por un lado, se considera que la academia ha presentado un declive en la calidad de sus galardonados. Varios de los críticos más severos han considerado las últimas elecciones de la academia como light. Esto pondría a Bob Dylan y su creación dentro de esta categoría, en desmérito no solo de su escritura, sino también de la idea de considerar la canción cantada como literatura (Cortés, 2016).

Dentro de estos opositores, algunos son tajantes al afirmar que la canción no es literatura (Solórzano, 2016). Son dos géneros artísticos desiguales. Sus medios de producción, sus canales de distribución y su producto final los hacen diferentes en naturaleza. Aún más, otro juicio en contra del Nobel de Dylan recae en la idea de que este premio representa simplemente un intento de renombrar la literatura norteamericana en las galas del Nobel, ausente e invisibilizada por más de veinte años (Ramírez, 2016). Esto implica que otorgarle el premio a Dylan fue un movimiento de simpatía política más que un acto de justicia artística (Ramírez, 2016).

Otra significativa y recurrente idea tiene que ver con los rasgos distintivos, propios de la creación de Dylan, de su estilo. La creación de Dylan es diversa. No descansa bajo la sombra de un estilo único. Por el contrario, a lo largo de su trayectoria ha presentado una cualidad nómada. Varios de los artículos mencionan etapas en su carrera (Solórzano, 2016;
Henri, 2016; Ulibarri, 2016). Una primera -por ejemplo- caracterizada por una postura crítica y de conciencia social. Su voz, su guitarra y su armónica son los únicos acompañantes para sus letras y melodías. Por otro lado, los estruendos y sonidos crudos del rock siguieron en una segunda etapa, así como letras más complejas, ambiguas y hasta de corte surrealista. El inicio de esta etapa marcó el inicio de la controversia que caracterizaría cada nuevo cambio en su carrera.

De este modo, su posterior conversión al cristianismo e incorporación de su credo en su producción representa una de sus facetas más criticadas. El constante cambio en su estilo engloba otro argumento reiterado en los artículos de periódico: la búsqueda y la ambigüedad como motor central de su creación artística (Solórzano, 2016; Henri, 2016; Ulibarri, 2016).

Dylan es y no es: es trovador hasta que toma una guitarra eléctrica y con su amplificador a todo volumen crea algunas de las canciones más emblemáticas de la historia del rock. Es creyente hasta que sus letras dejan a su Dios de lado y se enfocan en la experiencia humana. Resulta un autor vanguardista que busca desempolvar ritmos antiguos y cantos del dominio público. No se casa con una idea o una imagen, lo cual se ha reafirmado cada vez que ha cambiado de piel artística durante sus más de cincuenta años de carrera. No hay un Dylan, hay varios, cada uno con estilo propio, cada uno la contraparte de otro (Solórzano, 2016).

Un último punto relacionado con el estilo de Bob Dylan como músico y poeta es el de abordar varios estilos artísticos al mismo tiempo (Solórzano, 2016; Cortés, 2016; Henri, 2016). Cabe recalcar —por ejemplo- sus letras con influencia de los poetas de vanguardia de inicios del siglo XX, interpretadas a ritmo de folk o inclusive del blues más tradicional de su país. De este modo, Dylan mezcla estilos artísticos que aparentemente no tienen nada en común y los hace marchar tal cual perfecta yunta. Lo anterior conlleva a considerarlo como un artista muy complejo y de una especial facultad creativa, y no solo un trovador representante de una época y un movimiento. 
Los artículos periodísticos también exponen otra idea relacionada con la naturaleza de la literatura: los límites indeterminados de esta. Esta rama artística se ha entrecruzado con géneros y estilos no literarios. Uno de los ejemplos más destacados es el del artículo de periódico con un corte más literario (Ramírez, 2016; Henri, 2016). Existen los casos de periodistas cuyos artículos representan narrativas que cuentan una historia y utilizan estrategias literarias para presentar su mensaje. De este modo, dejan de ser simplemente recuentos de hechos, tradicionales artículos de periódico. Pasan a ser textos con un lenguaje muy refinado, inclusive artístico. Aún más, se mencionan los casos de varios galardonados con el Nobel de Literatura, los cuales han sido periodistas y no escritores de literatura per se. Sus producciones han sido journals y no novelas, poesía u otras manifestaciones tradicionales literarias.

Del mismo modo, se han dado casos de escritores de ficción de renombre que han creado crónicas más apegadas a la tradición periodística que a la literaria. Algunos escritores y poetas, por otra parte, han incursionado en otros géneros, como la canción para ser cantada, por ejemplo (Ramírez, 2016). Todos estos casos demuestran cómo en muchas ocasiones se han cruzado los límites entre lo literario y lo no literario, y se ha incurrido en la creación de un texto híbrido que cumple varias funciones y se puede ver desde múltiples perspectivas.

Como se ha visto, la crítica inmediata en respuesta al Nobel de Dylan representa en gran medida un esfuerzo por defender y legitimar su obra y su galardón. Sin embargo, la mayoría de esta crítica aborda el tema solo desde un punto de vista político, histórico o cultural. ¿Pero qué hay de su obra? ¿Por qué se dice que su estilo es poético? ¿Qué contienen sus letras cantadas que las hace merecedoras del Nobel de Literatura?

\section{ESTUDIO SOBRE DYLAN}

Para poder hablar de literatura, poesía y canción y de cómo las tres se entremezclan en la obra del músico y cantautor Bob Dylan, primero es necesario preguntarse qué es poesía, qué hay de literario en la canción y qué hay de rítmico en la palabra. a) Génesis de la poesía y su relación intrínseca con la música

La poesía constituye uno de los géneros literarios más antiguos. Sus inicios se remontan a los mismos inicios de la humanidad. Cada cultura antigua generó algún tipo de expresión poética y esta era acompañada por música. Varios de los ejemplos más significativos de estos primeros acercamientos a la poética se encuentran en la antigua cultura griega, cuna de la ciencia, arte y pensamiento de Occidente. Inicialmente, se hallan las obras del mítico poeta Homero, La Ilíada y La Odisea. Lo que actualmente se lee y encuentra en los estantes de literatura clásica de las librerías, fueron textos cantados y acompañados por instrumentos musicales de la época. Estos textos líricos tienen la palabra como su base, representan dos de los ejemplos más antiguos de la capacidad que tiene el ser humano para contar historias, y poseen algunas de las muestras más claras de figuras literarias. En este sentido, estos textos remiten a una época en la que no había distinción entre lo literario y lo musical. Eran una manifestación artística completa. En relación con lo anterior, Juan Carlos Ureña (2013) establece:

Primero fue la canción. La canción era música y poesía; un todo conectado a lo indecible. Los primeros seres humanos combinaron en sus ritos la palabra, el canto, la danza y la música. Poesía y música conformaban un solo concepto en la Antigüedad clásica, en las civilizaciones prehispánicas de América y durante gran parte de la Edad Media (...) De esta manera para hablar de lenguaje poético de la canción se debe recordar que se hace referencia a la confluencia natural de dos conceptos — poesía y música-, los cuales nacieron juntos ( $p$. xvii).

Estos dos géneros artísticos nacieron de esta necesidad que tiene y siempre ha tenido el espíritu humano de expresar — de una manera estilizada - una serie de cuestiones e inquietudes conectadas a la experiencia diaria, la génesis de todo arte. Dicho de otro modo, la experiencia humana conlleva la necesidad de expresión artística, como lo indica Guillermo Barzuna (1996): 
Desde los inicios de cualquier sociedad, el hombre, sujeto creador de cultura, se ha preocupado por cantar a las cosas fundamentales de su entorno: a su gente, a su tierra, a sus alegrías y penas, a sus creencias y a sus mitos (p. 28).

En estas primeras culturas se tiene el canto, el canto poético, como medio por excelencia para manifestar su concepción del mundo. Sin embargo, como afirma Ureña (2013), existe un momento de ruptura en el cual esta disciplina prima se quebranta en dos vertientes, la poesía y la música, como dos géneros diferentes y autosuficientes para continuar expresando las inquietudes del ser humano: "Eventualmente, en el devenir histórico, música y poesía se bifurcaron e iniciaron un proceso de desarrollo como artes independientes" (p. xvii).

Esta separación de caminos originó la creencia de que la poesía tiene como base la palabra, mientras que la música tiene el sonido y que no existe punto en común entre ambas artes y más importante, que la palabra en la poesía cantada no tiene valor poético. No obstante, Ureña (2013) también piensa que -pese a que estas artes tomaron caminos diferentes- existen casos en los cuales se han reencontrado cuando

los compositores y poetas colaboraban para crear sus obras vocales y musicales. Arias, ariettas, madrigales, motetes, cantatas, oratorios, óperas, baladas, requiems, lieds y una gran lista de formas que combinan la música y la poesía continuaron y continúan siendo utilizadas por los compositores ( $p$. 65).

El hecho de que artistas de ambas disciplinas acudan tan recurrentemente a la mezcla de las dos para lograr un producto -como en los casos expuestospone en evidencia la facilidad de acoplamiento que tienen la música y la poesía, la capacidad que tienen para mezclarse la una con la otra. Esta facilidad de acoplamiento está sujeta a las características formales y estructurales que heredan ambas artes de su inicio común, cuando las dos eran una.

Aún más, el siglo XX representa un siglo colmado de grandes cambios y experimentación no solo a nivel social, sino también a nivel cultural y artístico. Es así como en este siglo -y bajo este aire de búsqueda- la poesía y la música se vuelven a encontrar de nuevo:

Así, la musicalización de la poesía desde una perspectiva popular cobró gran importancia en el siglo XX, pues los nuevos trovadores experimentaban con canciones capaces de mantener su carácter popular, pero que además fueran portadoras de una alta calidad artística. Tal experiencia produjo un fenómeno poco estudiado en el medio académico: la canción poética del siglo XX, la cual también se proyecta en el siglo XXI (Ureña, 2013, p. 190).

Este esfuerzo representa el resurgimiento de una tradición milenaria, la cual -pese a que ya hacía varias centurias se había olvidado y tomado por dos disciplinas artísticas diferentes- reaparece de la mano de trovadores multifacéticos que son músicos y poetas, maestros del sonido y la palabra, que maravillan tanto por sus cualidades sonoras como por sus literarias. Cabe resaltar los nombres de varios artistas y agrupaciones de esta estirpe, como Bob Dylan, Leonard Cohen, The Beatles, Pink Floyd, Led Zeppelin, Joan Baez, The Velvet Underground, The Kinks, The Cure y por el lado de Latinoamérica, Sui Géneris, Luis Alberto Spinetta, Fito Paez, Atahualpa Yupanqui, Silvio Rodríguez, Soda Stereo y Violeta Parra, entre muchos otros.

Y es así como a lo largo del siglo XX e inicios del siglo XXI se reencuentra, en la baraja de productos culturales, esta poesía para ser cantada, escuchada y acompañada de música. En la canción literaria se incorporan una serie de recursos de la palabra, recursos poéticos que vienen a complementar y a llevar a otro nivel -a un nivel literario- la simple canción popular. Tal es en el caso de la música de Bob Dylan.

\section{b) La forma de la poesía cantada}

Antes de entrar de lleno a la noción de los recursos poéticos en la canción popular y cómo estos son evidentes en la producción de Dylan, es importante abordar el tema de la forma de canción cantada y sus vínculos con la poesía. 
Existen varios términos utilizados para abordar el tema de la forma de un poema. Estos son en su esencia conceptos musicales, como métrica y ritmo. La métrica de un poema es el número de sílabas en un verso. Del mismo modo, la métrica musical es el número de acentos en un compás. Aún más, con respecto al ritmo, Helena Beristein (1989) afirma que el ritmo en un poema está ligado con la pronunciación real de las palabras y de cómo estas generan la forma y acentuación en un verso (p. 82).

El ritmo musical se genera a partir de la acentuación de sonidos que hacen los instrumentos. En ambos casos, la métrica no determina el ritmo, sino la sonoridad de las palabras en el caso de la poesía y de los instrumentos, en el caso de la música. Beristein (1989) continúa: "el ritmo resulta tanto de la repetición regular de acentos, como de la articulación regular de un número de sílabas; es decir, la recurrencia de la medida silábica enmarca la recurrencia de la acentuación" (p. 78). Las palabras, sus sílabas, sus acentos y su forma van marcando la forma rítmica de un poema. La repetición de palabras y sonidos genera el sentido de repetición del ritmo entre versos. Este resulta ser progresivo y simétrico, pero más importante, ritmo y métrica, tanto en la música como en el poema, son sonido.

Cuando se habla de la música de Bob Dylan y de la música con letra cantada en general, se está tratando con dos tipos de ritmo y de métrica, los que son el resultado de la música y los que son resultado de la letra. El ritmo y la métrica de la música tienen que complementarse de manera armoniosa con sus contrapartes producidos por la palabra; de lo contrario, la canción presentaría problemas a niveles estructurales. Ureña (2013) acerca de este tema dice:

¿Cómo describir la unión que se establece entre texto, melodía, ritmo y ejecución? (...) toda canción (...) representa una unidad de texto y música. Los giros melódicos, los silencios, las paradas, el fraseo, la prosodia y hasta la interpretación son algunos de los múltiples elementos que establecen la conexión entre oyente y trovador (...) En las buenas canciones los versos juegan con la melodía, mantienen un ritual seductivo con la música, conservan cierta libertad, pero nunca se desconectan ni se desarticulan a nivel rítmico; es así como el ritmo musical y el del texto avanzan estrictamente acoplados, como el amarre de un buen grupo musical (...) la voz cantante, como en las improvisaciones, parece querer escaparse pero regresa al tiempo en el momento justo (p. 159).

La simultaneidad de ritmos en una canción cantada viene al generar armonía, al mismo tiempo que demuestra la habilidad de cantautores para jugar con ambos y traerlos a una asociación armoniosa, una yunta efectiva. Esto genera otra conjetura: la sonoridad de un poema juega un papel vital en la composición de este, tal vez más que su versión escrita. Esto se hace aún más evidente en la poesía en inglés, ya que la composición poética se hace basada en el factor sonoro de las palabras (las cuales difieren entre su pronunciación y su escritura) y no en su versión escrita. De este modo, un poeta velará por la armonía sónica del poema y no por un factor visual sobre el papel. Por supuesto que existe el caso de la poesía concreta, en la cual el factor visual juega un papel más significativo que el sonoro. Sin embargo, el fin de dicha poesía es generar una reacción por medio de lo que se observa y no lo que se escucha.

Al analizar un extracto de las canciones de Dylan, se puede evidenciar esta sonoridad métrico-rítmica del poema más claramente. En The Times They are A-Changin', utiliza una métrica de 3 tiempos (contados como un, dos, tres, un dos tres, un, dos, tres, etc.), en la cual se acentúa el primer tiempo siempre (esto es en el caso de la música. En el caso de la palabra, una sílaba acentuada es aquella con un sonido más intenso que la resalta del resto de sílabas). Esta es una métrica muy recurrente en música folclórica y el blues norteamericanos. La letra de la canción demuestra dicho ritmo y métrica al situar las sílabas con acento de varias palabras de dos o más sílabas en ese primer tiempo acentuado de la métrica musical:

$\begin{array}{llllll}3 & 1 & 2 & 3 & 1 & 2\end{array}$

Come mothers and fathers 


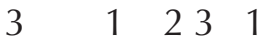

Throughout the land

$$
\begin{array}{lllll}
3 & 1 & 2 & 3 & 1
\end{array}
$$

And don't criticize

$\begin{array}{lllllll}2 & 3 & 1 & 2 & 3 & 1 & 3\end{array}$

What you can't understand

$\begin{array}{llllll}3 & 1 & 2 & 3 & 1 & 2\end{array}$

Your sons and your daughters

$$
\begin{array}{lllll}
3 & 1 & 2 & 3 & 1
\end{array}
$$

Are beyond your command

Las sílabas más oscuras representan aquellas que caen en el primer tiempo, el tiempo con acento fuerte de la métrica (come $=3, \mathrm{mo}=1$, thers $=2$, and $=3, \mathrm{fa}=1$, thers $=2$, through $=3$, etc). Dylan coloca las sílabas acentuadas de ciertas palabras en estos puntos fuertes del ritmo y de esta manera -al organizarlas en ciertos patrones- el cantautor logra que las palabras en su forma y sonido expongan el ritmo musical que amarra la canción como tal.

Respecto al ritmo, el poeta y ensayista mexicano Octavio Paz (1972) establece que "el período rítmico forma el núcleo del verso y no obedece a la regularidad silábica sino al golpe de los acentos y a la combinación de éstos con las cesuras y las sílabas débiles" (p. 25). De acuerdo con Paz, es la combinación de acentos fuertes con acentos débiles lo que crea el ritmo de un poema, teoría de ritmo que también se encuentra en las letras y canciones de Dylan.

Beristein (1989) utiliza las palabras del poeta Rubén Bonifaz Nuño para referirse a esta construcción musical por medio de las palabras y establece que un poema se va construyendo "alrededor del sonido de la palabra que va llamando a otra, cuyas vocales y consonantes lo apoyan o lo contradicen y que componen en conjunto una expresión efectiva" (p. 85). Como en un poema, la armonía musical se compone por medio de progresiones de sonidos entre acordes. De este modo, un cambio de acorde efectivo es un cambio que tiene notas en común entre los acordes, notas compartidas que van anunciando y llamando los cambios de un acorde a otro.

Al igual que Bonifaz, Dylan parece que construye su letra jugando con el sonido de las palabras y cómo estas se van acoplando al ritmo creado por la instrumentación de la canción. Beristein (1989) inclusive es más tajante al citar a Bonifaz y establecer que "los poemas no se escriben con palabras sino con ritmos" (p. 151).

\section{c) Las figuras literarias como recurso imaginativo en Bob Dylan}

Es momento de abordar el tema de los recursos poéticos en la canción y cómo el galardonado con el premio Nobel de Literatura utiliza estos en sus textos musicales.

El lenguaje que usa Bob Dylan en sus canciones es un lenguaje figurativo que -más que enunciar de manera clara- busca dejar una huella en la imaginación del receptor. De este modo, el cantautor recurre a las figuras literarias para crear mundos fantásticos cuyas relaciones lógicas no se apegan necesariamente a la realidad y es esta última característica la que hace a la poesía en general una expresión artística con posibilidades casi infinitas. Aún más, las figuras literarias generan experiencias lingüísticas y semánticas que solo tienen sentido dentro del contexto del poema. Beristein (1989) propone que "el poema siempre pone en juego un lenguaje figurado, un lenguaje constituido por figuras que afectan a distintos niveles lingüísticos del texto" ( $p$. 96). Estos recursos imaginativos dotan al simple lenguaje de una riqueza y variedad semántica, de una pluralidad de perspectivas e interpretaciones. Gran parte del arte y la belleza detrás de un poema son el resultado de la adecuada utilización de figuras literarias; una de estas, la metáfora.

La metáfora es una comparación directa entre dos cosas. La comparación o equivalencia se viene a dar mediante el desplazamiento del sentido de una a otra. Dicho desplazamiento viene a dar nuevas características y nuevos niveles semánticos que no tenía dicha cosa en un principio. Helena Beristein (1989) establece con respecto a la metáfora: 
En los tropos, pues, se produce la immutatio, es decir, una sustitución del sentido recto o literal por el sentido figurado. En la tradición se ha reflexionado sobre los tropos de palabra (como la metáfora) y los tropos de pensamiento (como la ironía) e igualmente sobre las figuras de pensamiento que no son tropos, que atañen a la lógica del discurso, y cuya lectura exige abarcar un más amplio contexto... (p. 67).

El desplazamiento o sustitución de sentido que se da en la metáfora produce un nuevo sentido que sobrepasa el orden lógico de un lenguaje lineal o literal. Pero es mediante la reflexión sobre la metáfora que esta adquiere un significado, una coherencia dentro del orden de ideas de un poema. Con respecto a la metáfora, Octavio Paz (1989), discutiendo sobre los enunciados de la poética aristotélica, afirma: "la metáfora es el principal instrumento de la poesía, ya que por medio de la imagen — que acerca y hace semejantes a los objetos distantes u opuestos- el poeta puede decir que esto sea parecido a aquello" (p. 23). El poeta mexicano, al igual que Beristein, sostiene que la metáfora es un acercamiento de dos objetos aparentemente lejanos, pero que por medio de la figura literaria se acercan para mostrar la lógi- ca detrás de su comparación. Sin embargo, Paz va más allá e incluso cree que la metáfora es la principal herramienta del poeta.

En el caso de Dylan, este utiliza como recurso la metáfora implícita, la que no se establece de manera directa en el poema, pero que se da por sentada para expresar otra idea. Por ejemplo, él establece en su canción Only a Pawn in Their Game:

Today, Medgar Evers was buried from the bullet he caught

\section{Hoy, Medgar Evers fue enterrado por la bala que pescó}

Este verso contiene una metáfora implícita: recibir un disparo asemeja a pescar un resfriado. Quizás Dylan quiere dar a entender que existe una relación entre la mala suerte de recibir un balazo y la simplicidad y arbitrariedad de contagiarse de un resfrío. La metáfora no se encuentra en el texto como recibir un balazo es pescar un resfrío. Sin embargo, como ya se estableció, el cantautor da por sentada la comparación y la utiliza como parte de una imagen más general, un entierro. Otras metáforas implícitas en sus letras son las siguientes:

\begin{tabular}{|c|c|c|c|}
\hline Original & Canción & Traducción al español & Objetos comparados \\
\hline $\begin{array}{c}\text { Then they'll kill him with } \\
\text { self-confidence } \\
\text { After poisoning him with } \\
\text { words }\end{array}$ & Desolation Row & $\begin{array}{c}\text { Después lo matarán con } \\
\text { autoestima } \\
\text { Al envenenarlo con } \\
\text { palabras }\end{array}$ & Palabras con veneno \\
\hline $\begin{array}{c}\text { With your mercury } \\
\text { mouth in the missionary } \\
\text { times }\end{array}$ & $\begin{array}{c}\text { Sad-Eyed Lady Of The } \\
\text { Lowlands }\end{array}$ & $\begin{array}{c}\text { Con tu boca de mercurio } \\
\text { en los tiempos de los } \\
\text { misioneros }\end{array}$ & Boca con mercurio \\
\hline $\begin{array}{c}\text { Beyond here lies nothin' } \\
\text { But the mountains of the } \\
\text { past }\end{array}$ & $\begin{array}{c}\text { Beyond Here Lies } \\
\text { Nothing }\end{array}$ & $\begin{array}{c}\text { Más allá de acá no hay } \\
\text { nada } \\
\text { Solo las montañas del } \\
\text { pasado }\end{array}$ & Montañas con pasado \\
\hline
\end{tabular}

Otra figura literaria de gran importancia y que asemeja a la metáfora es el símil, una comparación entre dos objetos mediante un conector, el más común siendo "como". La poesía de Dylan está carga- da de esta figura literaria, al punto de que se puede considerar como el recurso retórico más utilizado en sus letras. Algunos ejemplos de símiles en su trabajo son los siguientes: 


\begin{tabular}{|c|c|c|c|}
\hline Original & Canción & Traducción al español & Objetos comparados \\
\hline $\begin{array}{l}\text { Mona tried to tell me } \\
\text { To stay away from the } \\
\text { train line } \\
\text { She said that all the } \\
\text { railroad men } \\
\text { Just drink up your blood } \\
\text { like wine }\end{array}$ & $\begin{array}{l}\text { Stuck Inside Of Mobile } \\
\text { With The Memphis Blues } \\
\text { Again }\end{array}$ & $\begin{array}{c}\text { Mona intentaba decirme } \\
\text { Que me mantuviera lejos } \\
\text { de la línea del tren } \\
\text { Ella decía que todos los } \\
\text { hombres del ferrocarril } \\
\text { Beben tu sangre como } \\
\text { vino }\end{array}$ & $\begin{array}{c}\text { Chupar la sangre con } \\
\text { tomar vino }\end{array}$ \\
\hline $\begin{array}{l}\text { I'm tryin' to read your } \\
\text { portrait, but } \\
\text { I'm helpless, like a rich } \\
\text { man's child }\end{array}$ & Temporary Like Achilles & $\begin{array}{l}\text { Estoy tratando de leer tu } \\
\text { retrato } \\
\text { Pero soy incapaz, como } \\
\text { el hijo de un millonario }\end{array}$ & $\begin{array}{c}\text { La sensación de } \\
\text { incapacidad de intentar } \\
\text { leer un cuadro con la } \\
\text { de ser el hijo de un } \\
\text { millonario }\end{array}$ \\
\hline $\begin{array}{l}\text { Then you better start } \\
\text { swimmin' or you'll sink } \\
\text { like a stone }\end{array}$ & $\begin{array}{c}\text { The Times They Are } \\
\text { A-Changin' }\end{array}$ & $\begin{array}{l}\text { Así que más te vale } \\
\text { empezar a nadar o te } \\
\text { hundirás como piedra }\end{array}$ & $\begin{array}{c}\text { Una persona que no } \\
\text { puede nadar con una } \\
\text { piedra }\end{array}$ \\
\hline
\end{tabular}

Del mismo modo, Dylan utiliza otras figuras literarias para adornar su escritura y crear nuevos niveles de significado en sus canciones. Entre estas se encuentran casos de metonimia, la cual acarrea la sustitución de un objeto por otro; la paradoja, que es una contradicción a nivel superficial, pero que a un nivel más profundo tiene un significado; la personificación, atribuir características humanas a un objeto inhumano e hipérbole, la cual conlleva a una exageración:

\begin{tabular}{|c|c|c|c|}
\hline Original & Canción & Traducción al español & Figura literaria \\
\hline $\begin{array}{l}\text { Don't wear sandals } \\
\text { Try to avoid the scandals } \\
\text { Don't wanna be a bum } \\
\text { You better chew gum }\end{array}$ & $\begin{array}{c}\text { Subterranean Homesick } \\
\text { Blues }\end{array}$ & $\begin{array}{c}\text { No uses sandalias } \\
\text { Evita los escándalos } \\
\text { No quieres ser un vaga- } \\
\text { bundo } \\
\text { Mejor mastica goma de } \\
\text { mascar }\end{array}$ & Metonimia \\
\hline $\begin{array}{l}\text { You that never done } \\
\text { nothin' } \\
\text { But build to destroy }\end{array}$ & Masters of War & $\begin{array}{l}\text { Tú que nunca has hecho } \\
\text { nada } \\
\text { Más que construir para } \\
\text { destruir }\end{array}$ & Paradoja \\
\hline $\begin{array}{c}\text { Oh the fishes will laugh } \\
\text { As they swim out of the } \\
\text { path } \\
\text { And the seagulls they'll } \\
\text { be smiling } \\
\text { And the rocks on the } \\
\text { sand } \\
\text { Will proudly stand } \\
\text { The hour that the ship } \\
\text { comes in }\end{array}$ & When the Ship Comes & $\begin{array}{c}\text { Oh los peces reían } \\
\text { Mientras nadan fuera del } \\
\text { camino } \\
\text { Y las gaviotas sonreirán } \\
\text { Y las piedras en la arena } \\
\text { Orgullosas aguantarán } \\
\text { La hora en la que la nave } \\
\text { Ilegue }\end{array}$ & Personificación \\
\hline $\begin{array}{l}\text { Heard the roar of a wave } \\
\text { that could drown the } \\
\text { whole world }\end{array}$ & A hard rain's a-gonna fall & $\begin{array}{c}\text { Escuché el rugir de una } \\
\text { ola } \\
\text { Que podría ahogar al } \\
\text { mundo entero }\end{array}$ & Hipérbole \\
\hline
\end{tabular}


Los anteriores representan algunos ejemplos significativos del uso de figuras literarias por parte de Bob Dylan en sus canciones. El autor ha hecho uso de estos recursos retóricos de manera reiterativa a lo largo de toda su carrera musical. Estas figuras vienen a adornar, a transformar el simple lenguaje de una canción en lenguaje poético y de esta forma, dan un estilo artístico a sus palabras cantadas, las cuales trascienden su simple significado. Así, las canciones de Dylan se convierten en entes ambivalentes que pertenecen a dos mundos: el mundo de la palabra elaborada poética y literaria, y el mundo de la sonoridad de la música.

\section{OBSERVACIONES FINALES}

Desde la década de los 70, Bob Dylan ha destacado en los escenarios por su propuesta musical y artística. Sus álbumes no solo han aparecido en los lugares más altos de las listas de popularidad, sino que también han sido objeto de críticas favorables en tabloides especializados. Después de recolectar una vasta cantidad de premios en sus más de 50 años de carrera, el 2016 fue un año especial después de que se le otorgase el mayor reconocimiento del mundo literario, el Nobel de Literatura.

Pese a que este galardón suscitó considerable debate y duda respecto a la veracidad del premio, una parte de la crítica temprana elogió dicha escogencia y defendió tanto al cantautor y su trabajo como la decisión de la academia. Esta primera crítica se basa en argumentos como la similitud entre poesía y la canción para ser cantada, la génesis común que tienen estas dos y el hecho de que la canción del siglo XX retoma la vieja tradición del poeta que le canta al pueblo en yuxtaposición con el poeta de la misma centena que tiende a alienarse de este.

Aún más, para hablar de la música cantada de Bob Dylan y por qué esta es considerada por la Academia Sueca como literatura, se necesita hablar también del origen común que tienen las dos expresiones artísticas: la poesía y la música. La referencia a trabajos sobre la música y la literatura reveló que ha existido una relación muy cercana entre las dos artes. Ambas tienen su origen en la necesidad temprana que presenta la humanidad de cantar su experiencia en este mundo y pese a que en un momento de la historia las dos son tajantemente consideradas como expresiones artísticas diferentes, se vienen a reencontrar en el siglo XX. Dicho reencuentro es el que conlleva y justifica a finales del 2016 la decisión de la Academia Sueca.

Del mismo modo, un análisis detallado del trabajo de Dylan revela que sus canciones cuentan con considerables características que asemejan las de la poesía. Entre estas se puede resaltar el uso de métrica y ritmo, producidas no solo por la música, sino también por las palabras que van conformando los versos. Además, el cantautor utiliza figuras literarias para crear imágenes dentro de sus letras y originar nuevos matices de sentido que el simple lenguaje y sus relaciones lógicas no pueden causar. Figuras como la metáfora, el símil, la paradoja, la metonimia, la personificación y la hipérbole constituyen algunas de las imágenes recurrentes en el repertorio de este cantautor.

El galardón literario otorgado a Bob Dylan representa un hito no solo en la carrera de este músico, sino también en la historia de la música rock y la música popular que se produjo el siglo pasado. Este premio viene a crear conciencia sobre el valor de las producciones de una estirpe de músicos que decidieron ir más allá de las exigencias de la industria musical y plasmaron en sus letras y con sus instrumentos significativas obras de arte. Asimismo, este premio viene a abrirle la puerta a otros músicos para ser reconocidos como grandes artistas y poetas. A su manera, viene a modificar la noción del canon y qué es considerado valioso en términos de creación.

Finalmente, este Nobel representa un esfuerzo, no necesariamente consciente, para reducir brechas entre artistas de diferentes disciplinas y crear (o retomar en el caso de la música y la poesía) nuevos diálogos entre expresiones culturales y artísticas.

\section{REFERENCIAS BIBLIOGRÁFICAS}

Barzuna, G. (1996). Cantores que reflexionan: Las nuevas trovas en América Latina. San José: Editorial de la Universidad de Costa Rica. 
Beristein, H. (1989). Análisis e Interpretación del poema lírico. México: Universidad Autónoma de México.

Bobdylan.com. [sitio web]. Recuperado de http:// bobdylan.com/songs/.

Cortés, C. (23 octubre, 2016). ¿Algo huele podrido en Estocolmo? La Nación, pp. 6.

Henry, B. (20 octubre, 2016). Bob Dylan y el viento idiota literario. La Nación, pp. 21A.

Paz, O. (1972). El arco y la lira. Madrid: Fondo de Cultura Económica.

Ramírez, S. (29 octubre, 2016). De la critica a la guitarra. La Nación, pp. 22A.

Solórzano, G. (18 octubre, 2016). Bob Dylan, la estatua de un dios con cabeza. La Nación, pp. 4-5.

Ulibarri, E. (14 diciembre, 2016). Dylan y la ambigüedad creativa. La Nación, pp. 25A.

Ureña, J. C. (2013). Trovar: Memoria poética de la canción hispanoamericana. San José: Editorial de la Universidad de Costa Rica.

\section{OTROS TRABAJOS CONSULTADOS}

Baker, C. (2008). Cultural studies theory and practice (3era. ed.). London: Sage.

Beristein, H. (1995). Diccionario de retórica y poética. México: Editorial Porrúa.

Horton, M. (13 de octubre de 2016). Bob Dylan's Poetic Mastery: 10 Of His Finest Lyrics. NME.com. Recuperado de http://www. nme.com/blogs/nme-blogs/bob- dylanspoetic- mastery-10- of-his- finest-lyrics1554915\#RvvM4AtQS9dOdkF3.99.

Morgan Teicher, C. (14 de octubre de 2016). Why Bob Dylan's Songs Are Literature. thenewrepublic.com Recuperado de https://newrepublic. com/article/137811/bob-dylans- songs-literature. 


\section{Colaboradores}

\section{Isidro López-Aparicio Pérez}

El profesor Isidro López-Aparicio es licenciado y doctor en BeIlas Artes, graduado en la Universidad de Granada, España. Trabaja como profesor titular de esa misma casa de estudios.

Ha publicado numerosos artículos en prestigiosas revistas, y laborado en investigación como director de muchos proyectos, tesis y otro tipo de investigaciones.

Se especializa en creación artística, arte político y compromiso social, dibujo, imagen múltiple, comisariado y mediación.

Dirección de correo electrónico: isidro@ugr.es.

\section{Iraida Lisandra Bárzaga Morales}

Actualmente es investigadora en el Fondo Nacional de Desarrollo Científico y Tecnológico (FONDECYT), el principal fondo público del Gobierno de Chile. Trabajó en la Universidad de Concepción como colaboradora en la Pinacoteca, así como ayudante en la asignatura Literaturas Europeas del Siglo XX.

Es graduada en Historia del Arte en la Universidad del Oriente, Cuba. Además, obtuvo el grado de Magíster en Literaturas Hispánicas en la Universidad de Concepción, Chile. Actualmente estudia su Doctorado en Literaturas Latinoamericanas en la Universidad de Concepción, Chile.

Dirección de correo electrónico: irabm1987@gmail.com.

\section{David Blaz Sialer}

Es antropólogo, graduado en la Universidad Nacional Federico Villarreal, Perú. Ha cursado estudios de Filosofía en la Universidad Nacional Mayor de San Marcos, Perú y se graduó como Magíster en Estudios Culturales en la Pontificia Universidad Católica del Perú. Se especializa en psicoanálisis de la cultura, estudios sobre poder, visualidad y cultura.

Dirección de correo electrónico: diblazsialer@hotmail.com. 


\section{David Boza Méndez}

Trabaja como docente para la carrera de Enseñanza del Inglés en la Universidad de Costa Rica. También labora para la organización internacional ICOMOS. Obtuvo un Bachillerato en Lengua Inglesa, en la Universidad de Costa Rica, y una Maestría en Literatura Inglesa, en esa misma casa de enseñanza superior.

Dirección de correo electrónico: boza.braindamage@gmail.com.

\section{María Belén Castano}

Trabaja en la sección de Literaturas en Lenguas Extranjeras del Instituto de Filología y Literaturas Hispánicas "Dr. Amado Alonso" de la Universidad de Buenos Aires. Es Licenciada en Ciencia Política de la Universidad de Buenos Aires. También es Máster en Edición y Comunicación del Comunika Institute y Palombi Editore, en Italia.

Dirección de correo electrónico: belcastano@gmail.com.

\section{Francisco Cuéllar Santiago}

Es licenciado en Comunicación Audiovisual, graduado del Centro de Educación Superior Felipe II de Aranjuez, centro adscrito a la Universidad Complutense de Madrid, España, y doctorando en el departamento de Dibujo e Historia del Arte de la Facultad de Bellas Artes, en la Universidad de Granada, España. Trabaja como profesor de esa misma Universidad, y como Coordinador y Creativo de la Editorial PuntodePapel en Madrid, España.

Dirección de correo electrónico: fcuellar@correo.ugr.es.

\section{Claudio Díaz L.}

Es profesor de inglés, Magíster en Lingüística y Doctor en Educación, graduado en la Universidad de Concepción. Labora en la Universidad de Concepción, Chile, como Director del Magíster en Innovación de la Enseñanza, Aprendizaje y Evaluación del Inglés.

Dirección de correo electrónico: claudiodiaz@udec.cl.

\section{Aleixandre B. Duche-Pérez}

Es antropólogo graduado en la Universidad Nacional San Agustín de Arequipa, Perú. Obtuvo su Maestría en Antropología en la Pontificia Universidad Católica del Perú y en Artes, en la Universidad Nacional San Agustín de Arequipa, Perú. Se especializa en temas educativos, sobre nuevas religiosidades y protestantismo, e investigación cualitativa. Es docente a tiempo completo en la Universidad Católica de Santa María, Perú, y se encuentra cursando el doctorado en Administración Estratégica de Empresas.

Dirección de correo electrónico: aduche@ucsm.edu.pe. 
Colaboradores

\section{Minor Herrera}

Se ha desempeñado como profesor en la Universidad Técnica Nacional, donde ha impartido cursos para las carreras de Tecnologías de la Información, Producción Industrial, Administración de Empresas de Hospedaje y Electrónica, así como cursos del área de Estudios Generales de esa misma universidad.

Labora también como profesor para la Universidad de Costa Rica, donde ha impartido cursos para el Programa de Estudios Generales y para la carrera de Enseñanza del Castellano y Literatura.

Obtuvo su Bachillerato Universitario en Filología con énfasis en Enseñanza del Castellano y Literatura, en la Universidad de Costa Rica. Además, obtuvo su Bachillerato en Ciencias de la Educación Primaria en la Universidad Metropolitana Castro Carazo. También tiene una Licenciatura en Educación con énfasis en español de la Universidad de las Ciencias y el Arte. Su Maestría Académica en Literatura Clásica la obtuvo en la Universidad de Costa Rica.

Dirección de correo electrónico: minorj2007@hotmail.com

\section{Diana Martínez Alpízar}

Trabaja actualmente en la Escuela de Estudios Generales de la Universidad de Costa Rica. Cuenta con un Bachiller en Filología Española y una Maestría en Literatura Latinoamericana.

Dirección de correo electrónico: dimartinezalpizar@gmail.com.

\section{Giuliana Antonela Pates}

Trabajó en la Universidad Nacional de La Plata, Argentina, para la Facultad de Periodismo y Comunicación Social. Cuenta con un Profesorado en Comunicación Social y una Licenciatura en Comunicación Social, con orientación en Planificación Comunicacional, ambos títulos de la Facultad de Periodismo y Comunicación Social, Universidad Nacional de La Plata, Argentina. Cursa actualmente la Maestría en Sociología de la Cultura y Análisis Cultural, en el Instituto Altos Estudios Sociales de la Universidad Nacional de San Martín, Argentina.

Dirección de correo electrónico: giulianapates@hotmail.com.

\section{Gabriela A. Piñero}

Actualmente es docente e investigadora de la Universidad Nacional del Centro de la Provincia de Buenos Aires (UNICEN) y profesora de posgrado en la Universidad de Buenos Aires (UBA).

Es Licenciada en Artes, graduada en la Facultad de Filosofía y Letras, de la Universidad de Buenos Aires, Argentina. Es además Maestra en Historia del Arte con mención honorífica, graduada en la Universidad Autónoma de México. También es Doctora en Historia del Arte, con mención honorífica, de la Universidad Nacional Autónoma de México.

Dirección de correo electrónico: pinero.gabriela@gmail.com.

\section{Cecilia Quiroga C.}

Es profesora de inglés y Magíster en Educación, graduada en la Universidad de Concepción, Chile. Posee amplia experiencia en la enseñanza y aprendizaje del inglés en diferentes establecimientos educacionales de Chile.

Dirección de correo electrónico: cquiroga@udec.cl. 


\section{José Carlos Salinas-Valdivia}

Estudió Literatura en la Universidad Nacional de San Agustín de Arequipa, Perú. Fue ganador del IV Concurso Jorge Cornejo Polar en Cuento y Ensayo. Además, labora como colaborador en diversos periódicos y medios locales. Actualmente se encuentra cursando el doctorado en Literatura en la Universidad de Washington.

Dirección de correo electrónico: jcsalinasvaldivia@gmail.com.

\section{Rogelio Scott-Insúa}

Estudió Psicología en la Universidad Nacional de San Agustín de Arequipa, Perú. Es miembro de la Asociación de Psicoanálisis Lacaniano de Arequipa y de la Cátedra Libre Flores Galindo. Tiene un grado de máster en Antropología Médica y Global, otorgado por la Universitat Rovira i Virgili, España, y es candidato al doctorado en antropología y psicología médica en la Universidad de California en San Davis, EE. UU.

Dirección de correo electrónico: rscotti@gmail.com.

\section{Karin Sepúlveda N.}

Es profesora de inglés y Magíster en Educación en la Universidad de Concepción, Chile. Posee amplia experiencia en la enseñanza y aprendizaje del inglés en diferentes establecimientos educacionales de Chile.

Dirección de correo electrónico: ksepulveda@udec.cl. 


\section{Condiciones para publicar en la Revista Comunicación}

La Revista Comunicación publica documentos originales en los campos de las Humanidades (literatura, lenguaje, lingüística, comunicación, filosofía, sociología,

historia, religiones, psicología, artes y pedagogía).

Las secciones de la revista son las siguientes: artículos, foro, semblanzas, disertaciones, rescate de documentos, reseñas, crónicas, entrevistas y ensayo.

\section{ASUNTOS DE FONDO PARA TODAS LAS SECCIONES}

1. Los manuscritos deben tener un carácter principalmente académico o científico, resultado de investigaciones en el área de su interés. También pueden publicarse creaciones literarias originales, cuya calidad será determinada por el Consejo de Revisores y el Consejo Editorial de la Revista. Bajo ningún motivo serán aceptados aquellos documentos donde pueda ser demostrada la existencia de transcripción textual de otra obra (plagio).

2. Los documentos que pretendan incluirse en la sección de artículos, tendrán un mínimo de diez cuartillas y un máximo de treinta.

3. Las contribuciones pueden estar escritas en idiomas español, inglés o portugués.

4. Las contribuciones que deseen publicarse en la sección de "Artículos" deben incluir, tanto en el resumen como en su introducción, una pequeña justificación donde se explique el origen de la investigación, el tipo de investigación y sus conclusiones. Además, deberá aparecer explícitamente el proyecto de investigación del cual provienen (si es el caso), es decir, si procede de un proyecto de investigación y su nombre (si lo posee).

5. La extensión máxima de este resumen será de 250 palabras, y la mínima de 180.

\section{ASUNTOS DE FORMA}

1. El manuscrito deberá digitado en el procesador Microsoft Word, letra Times, 12 pts., con interlineado de 1,5 pts. y márgenes de $2,54 \mathrm{cms}$. en los cuatro lados de la hoja (arriba, abajo, izquierda y derecha).

2. Los textos deberán digitarse con sangrías, sin espacios entre cada párrafo. Deberán adjuntarse además aquellos signos que no aparezcan en el procesador.

3. Las citas, notas y referencias bibliográficas han de seguir el sistema APA en español, tercera edición en español.

4. El manuscrito debe incluir un resumen, redactado con oraciones completas, sin signos especiales y de doscientos cincuenta palabras como máximo, junto con el abstract correspondiente y el título del artículo en idioma inglés. En caso de no poder cumplir con el requisito de la traducción, debe indicarlo en el correo de entrega, junto con la respectiva justificación.

5. El manuscrito debe incluir entre seis y diez palabras clave en español y en inglés, que permitirán la ubicación de sus artículos mediante los sistemas de búsqueda electrónica. Esas palabras clave deben estar ubicadas en algún tesauro reconocido, cuyo nombre se incluirá al final del manuscrito. Se recomiendan los siguientes tesauros:

- Unesco: http://databases.unesco.org/thessp/

- Oficina Internacional de Educación y

Unesco: http://www.ibe.unesco.org/es/servicios/ documentos-en-linea/tesauro-de-la-educacionunesco-oie/sexta-edicion-2007.html

- OECD Macrothesaurus Chapter Headings: http://bibliotecavirtual.clacso.org.ar/ar/ oecd-macroth/es/index.htm

- Ciencia y Tecnología: http://thes.cindoc..csic.es/ index_SPIN_esp.php

- FAO: http://thes.cindoc..csic.es/index_SPIN_ esp.php

El autor puede utilizar otros de su preferencia, siempre y cuando sean de reconocida calidad y lo indique en el documento que envía.

6. Si el autor desea ilustrar su trabajo con alguna expresión gráfica específica, deberá hacerlo saber a la Dirección de la revista, e incluir el material, ya sea dentro del manuscrito o en un archivo separado. Ese material debe incluirse en una resolución de alta calidad (1080 p.).

7. Además, cuando se sugiera o se pretenda la inclusión de una imagen gráfica, deberán especificarse las condiciones de publicación de la imagen y respetarse los derechos de autor y de imagen; de igual modo, es necesario incluir los créditos y descripciones de la imagen y presentar a la Dirección de la revista una 
declaración de permiso para el uso del documento. Si las condiciones de publicación de la imagen no las puede acoger Comunicación, esto se le hará saber al autor.

8. La propuesta enviada deberá estar acompañada de un pequeño currículo del autor o autores, de máximo dos cuartillas, el cual deberá adjuntarse en un archivo aparte.

9. Los documentos que se presenten deben ser originales y no deben haber sido presentados para consideración ante ningún otro órgano editorial o de publicación. Por esa razón, junto con el manuscrito y el currículo, es necesario enviar a la Dirección de la Revista (ecorrales@itcr.ac.cr) una declaración firmada, en la que consten las condiciones anteriores, también en un archivo aparte del manuscrito.

Esta declaración de originalidad puede descargarla de nuestra página web, http://revistas.tec.ac.cr/index.php/comunicacion/pages/view/Directrices o solicitarla por correo a recom@itcr.ac.cr.

La originalidad del artículo se entiende como producción propia del autor, cuyo contenido no haya sido publicado en todo o en parte en ningún otro medio.

10. El manuscrito enviado debe incluir, al final, la dirección personal (postal o electrónica), el número telefónico del (de los) autor (es) y el nombre del tesauro utilizado.

11. Los manuscritos recibidos se someterán a doble dictamen ciego (sin el nombre de su autor), y serán enviados a un tercer miembro del Consejo de Revisores para un dictamen definitivo, cuando así se requiera. Comunicación recurre también a otros evaluadores externos para dictaminar las propuestas. Si este dictamen es positivo, el proceso continúa con el Consejo Editorial, quien discute y determina su publicación final. Su decisión es inapelable.

12. Recibir un documento no presupone que haya sido aceptado para publicación.

13. Puede consultar los lineamientos de dictaminación de artículos en nuestra página web, http://www.editorialtecnologica.tec.ac.cr/revistas/comunicación).

14. El proceso de evaluación de un documento será de diez semanas, como mínimo. Una vez que el documento es revisado por los pares externos, tendrá alguna de las siguientes condiciones:

o Aprobado para publicación, sin correcciones.

o Aprobado pero requiere correcciones del autor.

o Reprobado, no se publica.
La decisión de los pares es inapelable.

Los autores son responsables de efectuar los cambios indicados por los revisores, en caso de que así se solicite.

La edición (diagramación, corrección filológica, etc.) de la revista Comunicación es inapelable.

Los manuscritos deberán enviarse a la Dirección de la Revista, por correo electrónico (ecorrales@itcr.ac.cr) o al correo regular de la revista (recom@itcr.ac.cr) con sus respectivos archivos adjuntos. La publicación es semestral y se reciben documentos para dictaminación todo el año.

\section{LICENCIAMIENTO Y PROTECCIÓN INTELECTUAL}

Todos los artículos y los ensayos publicados están protegidos por las licencias Creative Commons (CC), que constituyen un complemento al derecho de autor tradicional, en los siguientes términos:

a. Se impide la obra derivada (es decir, no se puede alterar, transformar ni ampliar el documento).

b. Siempre debe reconocerse la autoría del documento referido.

c. Ningún documento publicado en la Revista Comunicación, puede tener fines comerciales de ninguna naturaleza.

Mediante estas licencias, la revista garantiza al autor que su obra está protegida legalmente, tanto bajo la legislación nacional como internacional. Por tal motivo, cuando sea demostrada la alteración, la modificación o el plagio parcial o total de una de las publicaciones de esta revista, la infracción será sometida a arbitraje internacional en tanto que se están violentando las normas de publicación de quienes participan en la Revista y la Revista misma. La institución afiliada a Creative Commons para la verificación en caso de daños y para la protección de dichos productos es el Instituto Tecnológico de Costa Rica, mediante la Editorial Tecnológica y la Vicerrectoría de Investigación

Las presentes condiciones son indispensables para someter el documento a dictaminación. Su incumplimiento obliga al rechazo ad portas del manuscrito.

Estamos indizados en Scielo, ERIH Plus, e-revistas y Latindex.

¡Gracias por su interés en Comunicación! 


\section{Requirements to publish in The journal Comunicación}

\section{REQUIREMENTS TO PUBLISH IN THE JOURNAL COMUNICACIÓN OF THE SCHOOL OF LANGUAGE SCIENCES, COSTA RICA TECHNOLOGICAL INSTITUTE}

The jounal Comunicación publishes original documents in the fields of Humanities (literature, language, linguistics, communication, philosophy, sociology, history Religions, psychology, art and pedagogy.

The sections of the journal are as follows: articles, forum, biographies, dissertations, retrieval of published documents, commentaries, chronicles, interviews and essay.

\section{ISSUES RELATED TO THE CONTENT IN ALL SECTIONS}

1. The papers ought to have a mainly academic or scientific nature resulting from research in the area of interest. Original artistic creations may also be published, whose quality will be determined by the Board of reviewers and the Editorial board of the journal. Under no circumstance whose textual transcription of another piece of art can be proven (plagiarism) will be accepted. The number of pages should be from 10 to 30 .

2. The papers can be written in Spanish, English or Portuguese.

3. The papers to be published in the "Articles" section a short rationale which explains the origin of the research, the kind of research and its conclusions both in the abstract as in in the introduction. Furthermore, the research project from which the research derives (if it the case, this is, if the articles derives from a research project and its name (if it has one), ust explicitly appear.

4. The maximum length of the abstract will be 250 words and the minimum 180 words. La extensión máxima de este resumen será de 250 palabras, y la mínima de 180.

\section{FORMAL ASPECTS}

1. The papers must be written in a Microsoft processor, Times Font, 12 points, 1.5 spaced and 2.,4 margins on each side of the page..

2. The texts must be indented without spaces between the paragraphs. Characters which do not appear in the processor must be included..

3. The quotation and bibliographical references must stick to APA's guidelines in Spanish third edition in Spanish.

4. The paper must include a summary written in complete sentences, without special characters and with a maximum of two hundred words, together with an abstract and the title of the article in English. In case the translation cannot be provided, it must be indicated in the e-mail sent, together with and explanation..

5. The paper must include between six to ten key words in Spanish and English, which will allow the search of the articles using electronic search engines. These key words must be found in a recognized thesaurus, whose name will be referred to at the end of the paper. The following thesaurus are recommended:

- Unesco: http://databases.unesco.org/thessp/

- International Education Office and Unesco: http://www.ibe.unesco.org/es/servicios/ documentos-en-linea/tesauro-de-la-educacionunesco-oie/sexta-edicion-2007.html

- OECD Macrothesaurus Chapter Headings: http://bibliotecavirtual.clacso.org.ar/ar/ oecd-macroth/es/index.htm

- Ciencia y Tecnología: http://thes.cindoc..csic.es/ index_SPIN_esp.php

- FAO: http://thes.cindoc..csic.es/index_SPIN_ esp.php

The autos may use others of their preference as long as they are highly-recognized and they indicate it in the sent document.

6. If the author wishes to illustrate their work with any kind of graphic expression, they must let the Journal know in advance as well as include the material whether as part of the paper or in a separate file. The material must be of high quality of resolution (1080 p.).

7. Furthermore, when the author suggests or intends to include a graphic image, they must specify it, as well as respect the copyright and the image right. Likewise, it is necessary to include the credits and 
description of the image and provide the Board with a statement informing of the permission to use the document. If the conditions to publish the image are not accepted by the Journal, Comunicación, they will let the author know. La propuesta enviada deberá estar acompañado de un pequeño currículo del autor o autores, de máximo dos cuartillas, el cual deberá adjuntarse en un archivo aparte.

8. The documents submitted must be original and not having been turned in for review to any other editorial board or publication. For this reason, together with the paper and the resume, it is necessary to send to the Journal's Direction (ecorrales@itcr.ac.cr) a signed statement acknowledging the above-mentioned conditions, also in a file separate from the paper.

This statement of originality can be downloaded from our webpage http://revistas.tec.ac.cr/index.php/comunicacion/pages/view/Directrices or be requested via e-mail to recom@itcr.ac.cr.

9. Thr originality of the paper must be understood as the author's individual production, whose content hasn't been published as part or as whole in any other media.

10. The paper must include the mail or e-mail address of the author, their phone number, and the name of the thesaurus used. The papers will be subject to double blind review (without the name of the author), and will be sent to a third member of the Board of Reviewers for a final decision as required.. Comunicación also resorts to other external evaluators in order to decide on the papers. If the decision is affirmative, the process continues before the Editorial Board, which discusses and determines its final publishing. Its decision has no appeal.

11. Receiving a document does not mean it will be published

12. You can consult the guidelines for final decisions in our web page., http://www.editorialtecnologica.tec. ac.cr/revistas/comunicación).

13. The process of evaluation of a document will take ten weeks minimum. Once the document is reviewed by the external evaluators, one of the next scenarios is possible.:

○ Approved for publishing, no corrections needed.

- Approved for publishing but it requires corrections by the author.

○ Rejected, it won't be published. Reprobado.

The decision of the evaluators has no appeal.
The authors are responsible for making the changes required by the reviewers, whenever requested.

The edition (diagramming, philological corrections etc.) by Comunicación has no appeal.

The papers must be sent to the Journal's Director via electronic mail (ecorrales@itcr.ac.cr) or to the account of the journal (recom@itcr.ac.cr) with the corresponding enclosed files. The publication is semesterly and papers are received during the whole year..

\section{GUIDELINE RELATED TO COPYRIGHT AND INTELLECTAUL PROPRTY}

All articles and essays published are protected by the Creative Commons (CC) licenses, which constitute a complement to the traditional copyright in the following term:

a. Derived Works are not allowed (this is, the document cannot be altered, transformed or abridged).

b. The authorship of the work must be acknowledged at all times.

c. no document published in Comunicación can have commercial purposed of any nature.

By means of these licenses, the journal guarantees the author that their work is legally protected under both thed national and the international. Hence, if any alteration, modification or partial or total of a plagiarism in one of the publications of this journal, the infraction will be subject to the international arbitration if it violates on of the publishing regulations of the journal or any party of the Journal. The institution affiliated to Creative Commons for the verification in case of damages is the Instituto Tecnológico de Costa Rica, through the Technological Publishing House and the Research Vice-Dean's Office.

The hereby conditions are absolutely necessary to subject a paper to review. Their lack of compliance means an ad portas rejection of the paper.

We are indexed at Scielo, ERIH Plus, e-revistas and Latindex. 